UNIVERSIDADE DE SÃO PAULO

FACULDADE DE FILOSOFIA, LETRAS E CIÊNCIAS HUMANAS

DEPARTAMENTO DE GEOGRAFIA

PROGRAMA DE PÓS-GRADUAÇÃO EM GEOGRAFIA FÍSICA

\title{
Distribuição espacial do fluxo radiativo em ondas longas na Região Metropolitana de São Paulo
}

\author{
Antonio Jaschke Machado \\ Tese apresentada ao Programa de Pós- \\ Graduação em Geografia Física do \\ Departamento de Geografia da Faculdade \\ de Filosofia, Letras e Ciências Humanas \\ da Universidade de São Paulo, para a \\ obtenção do título de Doutor em Ciências. \\ Orientador: Prof. Dr. Tarik Rezende de Azevedo
}

São Paulo

2009 
Ó rama ó que linda rama ó rama da Oliveira O meu par é o mais lindo Que anda aqui na roda inteira

Que anda aqui na roda inteira Aqui e em qualquer lugar Ó rama ó que linda rama Ó rama do olival

Eu gosto muito de ouvir Cantar a quem aprendeu Se houvesse quem me ensinara Quem aprendia era eu

Não me inveja tu quem tem Carros, parelhas e montes Só me inveja tu quem bebe A água em todas as fontes

(Popular alentejano) 


\section{Agradecimentos}

O autor é muito grato aos seguintes que, de algum modo, ajudaram enormemente à realização desta tese.

Ao $\mathrm{CNPq}$, que tem me dado suporte financeiro para que eu possa prosseguir.

A FAPESP que nos deu suporte financeiro para materializar um sonho.

Ao Sérgio e companheiros da SR Motores, aos irmãos Giba e Sr. Ailton do Vaga-lume, ao Gilberto, aos irmãos Chico e Renato da Central Pneus, à Sr ${ }^{a}$. Maria Helena e ao Toninho do Jaguaré, por terem todos colaborado com muita prontidão e habilidade para tornar e manter o laboratório móvel uma realidade nas ruas da cidade.

A todos os funcionários do Departamento de Geografia, pela atenção e colaboração.

Aos grupos de estudo: Rosiane, João Cláudio, Daniela, Rogério, Henrique, Daniel, Marcel, Michelle, Melanie e a tantos novos e bem-vindos companheiros.

Ao Prof. Dr. Ricardo Augusto Felício, pelo companheirismo nesta estrada de resgates históricos, meteorológicos e climáticos.

Ao Prof. Dr. Élvio Rodrigues Martins, que sempre me recebeu com um abraço, pela presença decisiva no importante momento de reconhecer um sentido geográfico ao meu trabalho.

Aos queridos Rubens Leonardo e Márcia Regina, que inesgotavelmente insentivaram-me a continuar a jornada.

À minha querida Regina, que por muitos anos tem ouvido a música.

Ao meu pai querido (in memorium), Antonio, que me ensinou amar a natureza, introduziu-me ao pensar científico e mostrou-me apaixonadamente os lugares desta cidade, seus caminhos e suas transformações.

À minha mãe querida, Angela, que me ensinou todos os sabores desta vida. O salgado do trabalho, o amargo do tropeço, o azedo do sempre recomeçar e o doce do conquistar.

Especial e fraternalmente, ao Prof. Dr. Tarik Rezende de Azevedo, em nome de todos, pelas lições recebidas. 


\section{Resumo}

Muitas vezes, é necessária uma melhor compreensão a respeito da distribuição espacial do fluxo radiativo em ondas longas. Este fluxo é em geral representado pelos estudos em climatologia urbana. Alternativamente, é representado como um estudo interdisciplinar.

Novos procedimentos são considerados, porque a superfície urbana é composta de uma variedade muito ampla de elementos. Incluindo um conjunto amostral baseado em observações de transetos móveis automáticos através de várias travessias na Região Metropolitana de São Paulo, além de estimativas paramétricas e considerações de análise escalar.

Olhando os objetivos da tese, é fornecida uma contribuição ao desenvolvimento metodológico nos trabalhos de campo, em particular aos climatologistas e planejadores urbanos. Os resultados obtidos implementam a discussão a respeito dos ambientes modificados pelo homem.

É apresentada a natureza do fenômeno estudado e o método aplicado é focalizado. São analisados os aspectos essenciais que contribuem para a distribuição do fluxo radiativo nos canyons urbanos. Como a expressão do balanço de energia é uma importante ferramenta para a compreensão do clima urbano, estimativas dos fluxos turbulentos também são considerados.

Palavras-chave: transeto móvel, radiação, clima, urbano, cidade de São Paulo. 


\begin{abstract}
Many times, it is necessary a better comprehension about the spatial distribution of the longwave radiative flux. This flux is represented just as much by the studies on urban climatology. Alternatively, it is represented as an interdisciplinary study.
\end{abstract}

New procedures are considered, because the urban surface is made up of widely varying elements. Including a sampled dataset based on automatic mobile transects observations through several traverses in the Metropolitan Area of São Paulo, besides parametric estimates and scalar analysis considerations.

Regarding the thesis objectives, it is given a contribution to the method development in the fieldworks, in particular to the urban climatologists and urban planners. The obtained results improve the discussion on the manmodified environments.

It is explained the nature of the studied phenomena and the applied method it is focused. It is analyzed the essential aspects that contibute to the radiative flux distribution in the urban canyons. As the energy balance expresion is an important framework to the comprehension of the urban climate, estimates of the turbulent fluxes are also considered.

Key words: mobile transect, radiation, climate, urban, São Paulo city. 
Lista de figuras $\quad$ xi

Lista de tabelas $\quad$ xviii

Símbolos xix

Introdução 1

Objeto, objetivo e hipótese $\quad 2$

$\begin{array}{ll}\text { Apresentação } & 3\end{array}$

Trajetória do autor $\quad 4$

Climatologia como fronteira científica $\quad 6$

a) Introdução a um ensaio entre meteorologia e geografia 6

b) Crítica aos métodos de estudos climáticos 11

c) Observação, o elemento fundamental da análise $\quad 14$

d) Implicações atuais de concepções climáticas distintas $\quad 17$

1. Onda longa e áreas urbanas 19

1.1. CAMADA LIMITE URBANA SEGUNDO A ESCOLA OKEANA 20

1.2. $\quad$ MEIO E RELAÇÕES

1.2.1. Metrópole e rede urbana $\quad 51$

1.2.2. Distribuição 53

1.3. PADRONIZAÇÕES 56

1.3.1. Padrão energético 56

1.3.2. Padrão dinâmico $\quad 58$

$\begin{array}{ll}\text { 1.3.3. Urbanização } & 60\end{array}$

1.4. CARACTERÍSTICAS URBANAS $\quad 61$

1.4.1. Balanços de energia do sistema geral humano-urbano 62

1.4.2. Natural e antrópico 64 
2.

2.1.

COBERTURAS

2.1.1. Material, procedimentos e métodos

2.1.1.1. O laboratório móvel

2.1.1.2. Aferição dos sinais observados

2.1.1.3. Resolução dos dados adquiridos 68

2.1.2. O mosaico urbano 72

2.1.3. Transetos e pontos de amostragem 77

2.1.3.1. Experimento piloto e magnitude do fluxo 77

2.1.3.2. Domínio espacial e amplitude escalar observada 77

2.1.4. Estimativa de $\mathrm{L}^{*}$ 80

2.1.4.1. O fluxo L 个 noturno 80

2.1.4.2. O problema do fluxo L $\uparrow$ diurno

2.1.4.3. Reescrevendo a parametrização de Offerle em termos de $K^{*}$

2.1.5. Outras investigações climáticas

2.1.6. Parâmetros meteorológicos 83

2.2.1. Observações em movimento 86

2.2.2. Observações estáticas 86

2.3 . DIMENSÃO TEMPORAL DOS DADOS

2.3.1. Ritmos e durações 87

2.3.1.1. Simultaneidade dos fluxos energéticos natural e antrópico 87

2.3.1.2. Efeito das atividades humanas 89

2.3.1.3. Efeitos do meio urbano 
2.3.2.3. Dispositivo 94

2.3.3. Espacialização do equilíbrio térmico 96

$\begin{array}{ll}\text { 2.3.3.1. Transetos específicos } & 97\end{array}$

2.3.3.2. Área metropolitana $\quad 99$

$\begin{array}{ll}\text { 2.3.4. Variabilidade de } \mathrm{Q}^{*} & 103\end{array}$

2.3.4.1. Amplificação diária 105

2.3.4.2. Atividade humana 111

2.4. DIMENSÃO ESPACIAL DOS DADOS GEORREFERENCIADOS 114

$\begin{array}{ll}\text { 2.4.1. Lugares } & 114\end{array}$

2.4.1.1. Mancha urbana 114

2.4.1.2. Além da metrópole $\quad 114$

2.4.2. Localização em primeira aproximação 117

2.4.2.1. Uma rede metropolitana 117

2.4.2.2. Adensamento no município $\quad 118$

2.4.2.3. Extremos menos adensados $\quad 118$

2.5. NATUREZA DAS EMISSÕES $\quad 119$

$\begin{array}{ll}\text { 2.5.1. Resultados em transetos } & 119\end{array}$

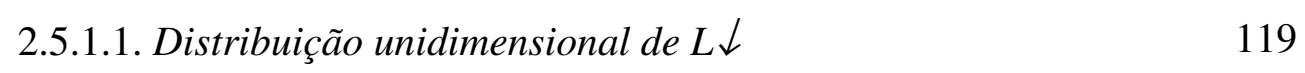

2.5.1.2. Efeitos múltiplos sobre $L \downarrow$

$\begin{array}{lr}\text { 2.5.2. Totalização dos resultados } & 120\end{array}$

$\begin{array}{ll}\text { 2.5.2.1. Avaliação } & 125\end{array}$

2.5.2.2. Inferência 127

2.5.2.3. Emissividade 132

$\begin{array}{ll}\text { 2.5.3. Natureza da cidade } & 134\end{array}$

2.5.3.1. Métodos alternativos $\quad 134$

$\begin{array}{ll}\text { 2.5.3.2. Formas } & 135\end{array}$ 
3.

3.1. DISTRIBUIÇÃO DAS EMISSÕES

3.1.1. Análise em mesoescala

3.1.1.1. Controle turbulento

3.1.1.2. Fluxo divergente

3.1.1.3. Distribuição tridimensional

3.1.1.4. Estabilidade vertical

3.1.2. Relação com os poluentes 148

3.1.2.1. Parametrização das concentrações 149

3.1.2.2. Mistura termodinâmica 150

3.1.3. Balanço energético 166

3.1.3.1. Parametrização do fluxo $L_{a} \downarrow$ 166

3.1.3.2. Termos do balanço energético 169

3.1.4. Efeito cinemático

3.2. O LUGAR DAS EMISSÕES

3.2.1. Caracterização térmica completa

3.2.2. Análise em topoescala 186

3.2.2.1. Umidade 186

3.2.2.2. Fluxos distribuídos climaticamente

3.2.2.3. Classificação

3.2.2.4. Estudo de caso

3.3. COMPREENSÃO SOBRE OS ELEMENTOS EMISSORES 198 URBANOS

3.3.1. À guisa de conclusão 198

3.3.1.1. A variabilidade dos fluxos radiativos observada em 198 movimento

3.3.1.2. O efeito temporal sobre observações espaciais em movimento 
3.3.1.4. Localização das emissões térmicas 208

$\begin{array}{ll}\text { 3.3.2. Considerações finais } & 211\end{array}$

$\begin{array}{lll}\text { Anexo 1. } & \text { Formulário } & 214\end{array}$

$\begin{array}{lll}\text { Anexo 2. } & \text { Fichas dos experimentos } & 217\end{array}$

$\begin{array}{ll}\text { Referências } & 258\end{array}$ 


\section{Lista de figuras}

Figura 2.1 - Laboratório móvel, em perspectiva frontal (a) e lateral (b), saldo - radiômetro com o anel anti refratário (c) e campo de visão (d) gerado pelo dispositivo.

Figura 2.2 - Plataforma do laboratório móvel (a), sensor IRT fixo em disco giratório (b), pirgeômetro (c), sensor RTD acoplado ao tubo de ventilação (d) e sistema de aquisição de dados em perspectiva frontal (e) e posterior com conectores adaptados (f).

Figura 2.3 - Matiz asfáltica. 1 - homogeneidade (a) a (d). 2 - irregularidades (e) a (h). 3 - de re-capeamentos a respingos (i) a (l). 4 - das rachuraduras às faixas (m) a (p). 5 - das faixas em asfalto liso às faixas em asfalto altamente irregular, com re-capeamentos de diversas idades (q) a (t). 6 - altamente complexos, do sombreado de geometria simples à cena com materiais diversos de elementos dos veículos (u) a (x).

Figura 2.4 - Matiz celeste. 1 - do céu aberto ao nublado com alto-cumulus: (a) a (d). 2 - do totalmente nublado, passando pelas obstruções mistas com árvores e edifícios, às copas desprovidas de folhas: (e) a (h). 3- das copas esparsas às copas densamente foliadas: (i) a (1).

Figura 2.5 - Matiz celeste correspondente à Figura 2.4, observada a partir do nível do pirradiômetro.

Figura 2.6 - Matiz vertical, do sinal distante, onde a presença térmica do alvo é sobreposta pelo ar circundante, ao sinal próximo, com elevada influência do alvo. 1 - alvos distantes: (a) a (d). 2 - alvos próximos: (e) a (h). 3 das cenas arborizadas às cenas mistas: (i) a (1). 4 - das árvores próximas às paredes próximas: (m) a (p). 5 - das cenas com paredes muito próximas às cenas que contém exclusivamente paredes, ainda com alguma diversidade de materiais: (q) a (t). 6 - cenas quase homogêneas, das paredes muito próximas e regulares à cena com veículos de grande área lateral parados ou em movimento (u) a (x).

Figura 2.7 - Malha viária que compõe os transetos das escalas 1 e 2 (linhas azul e vermelha) de amostragem, disposta sobre uma imagem da estimativa de Q* (para os detalhes da obtenção desta imagem classificada ver MACHADO e AZEVEDO, 2006c). O polígono representado pela linha branca corresponde ao limite entre a área da RMSP considerada urbanizada (interior) e a área na qual as características urbanas são atenuadas (exterior), para a escala regional.

Figura 4.1 - Fluxos envolvidos na troca de energia entre um ser humano e seu ambiente.

Figura 4.2 - Veículo com dispositivo dianteiro (a) para fixação de pirradiômetro (b).

Figura 4.3 - Distribuição espacial do fluxo $L \downarrow$ (a) e das temperaturas do ar (linha escura) e do anel (linha clara) ao redor do radiômetro (b) através das Avenidas Cerro Corá e Heitor Penteado, desde a Avenida São Gualter até o cruzamento com a Avenida Pompéia, nos dias 21 de maio (linhas contínuas abaixo), $1^{\circ}$ de março (linhas contínuas acima) e 16 de fevereiro (linhas pontilhadas acima) de 2007. Também são representados os máximos e mínimos (linhas claras) observados para $\mathrm{L} \downarrow$ e o desvio (barras verticais) observado para as temperaturas. 
Figura 4.4 - Variabilidade espacial, em transverso, das magnitudes amostradas da temperatura do ar (a) e da temperatura sobre a superfície do anel de PVC (b).

Figura 4.5 - Histogramas das magnitudes amostradas da temperatura do ar (a) e da temperatura sobre a superfície do anel de PVC (b).

Figura 4.6 - Percursos geo referenciados realizados com o laboratório móvel, no eixo Anhangüera - Marginal Pinheiros (a) e no eixo Francisco Matarazzo - Pacaembu - Higienópolis (b). Os números indicados através dos percursos representam determinadas posições em $\mathrm{km}$.

Figura 4.7 - Evolução temporal da temperatura do ar (a), da umidade específica (b) e da direção (c) e velocidade(d) do vento próximo à superfície, nos dias 30 de dezembro (círculo fechado) e 7 de fevereiro (círculo aberto), para uma estação meteorológica situada na porção sul da cidade de São Paulo e para o veículo em deslocamento nas ruas (estrela), em um período de 12 horas em torno do intervalo (polígonos entre as linhas verticais pontilhadas) de realização dos experimentos.

Figura 4.8 - Distribuição temporal do saldo radiativo máximo (acima) e mínimo (abaixo) absolutos observados no eixo Anhangüera - Marginal Pinheiros (a) e no eixo Francisco Matarazzo - Pacaembu - Higienópolis (b).

Figura 4.9 - Distribuição espacial do saldo radiativo máximo (acima) e mínimo (abaixo) absolutos observados no eixo Anhangüera - Marginal Pinheiros (a) e no eixo Francisco Matarazzo - Pacaembu - Higienópolis (b).

Figura 4.10 - Marginal dos Pinheiros (a) ao lado da Cidade Universitária, e Av. Francisco Matarazzo (b) ao lado do Parque da Água Branca. A linha reta clara indica o trajeto do veículo.

Figura 4.11 - Idem à Figura 4.9, para os dias 12 (a) e 22 de abril (b).

Figura 5.1 - Rede de trajetos efetivamente geo referenciados entre 27 de julho de 2006 e 31 de maio de 2007, e sua localização relativa à fronteira geo política do município de São Paulo.

Figura 6.1 - Variabilidade espacial, em transeto, das magnitudes amostradas do saldo radiativo em ondas longas verificado sobre o veículo (a), saldo radiativo multi-espectral verificado acima da superfície (b), temperatura sobre as superfícies verticais à esquerda do veículo em deslocamento (c) e temperatura sobre as superfícies verticais à direita do veículo em deslocamento (d).

Figura 6.2 - Histogramas das magnitudes amostradas do aaldo radiativo em ondas longas verificado sobre o veículo (a), saldo radiativo multi-espectral verificado acima da superfície (b), temperatura sobre as superfícies verticais à esquerda do veículo em deslocamento (c) e temperatura sobre as superfícies verticais à direita do veículo em deslocamento $(\mathrm{d})$.

Figura 6.3 - Vista do céu na Rua Dardanelos (a), das árvores na Praça John Lennon (b), do asfalto na Rua Sebastião Cortês (c) e das superfícies verticais na Rua Tito (d). 
Figura 6.4 - Variabilidade temporal das temperaturas, na Rua Sebastião Cortês, do ar (a), das folhas das árvores (b), do asfalto (c) e dos muros (d). As linhas claras indicam superfícies originariamente expostas, enquanto as linhas escuras indicam superfícies originariamente sombreadas.

Figura 6.5 - Variabilidade espacial, em transeto, das magnitudes estimadas e da respectiva distribuição de freqüências do fluxo incidente $(a, b)$, do fluxo emitido $(c, d)$ e do saldo radiativo em ondas longas (e, f) sobre a superfície do piso urbano.

Figura 6.6 - Variabilidade espacial, em transeto, das magnitudes estimadas e da respectiva distribuição de freqüências do fluxo emitido pelas paredes à direita do veículo em deslocamento $(\mathrm{a}, \mathrm{b})$, e do fluxo emitido pelas paredes à esquerda (c, d), em ondas longas.

Figura 6.7 - Representação geométrica do fluxo radiativo resultante em ondas longas, sentido por um indivíduo deslocando-se no interior de um canyon urbano.

Figura 6.8 - Histogramas das magnitudes amostradas da temperatura da cobertura asfáltica (a) e da temperatura da parede (b), verificadas na Rua Sebastião Cortês, Zona Oeste do município de São Paulo.

Figura 7.1 - Domínio principal em coordenadas UTM, com a localização da mancha urbana principal da metrópole paulistana definida pela análise preliminar do fluxo $\mathrm{Q}^{*}$. Este domínio corresponde a um quadrado com lados medindo $80 \mathrm{~km}$ (ver item 3b, Figura 7.23).

Figura 7.2 - Distribuição espacial da hora local (a), do mês (b) e do dia da semana (c) em que foram realizadas as observações. Também é apresentada a distribuição espacial da velocidade média em $\mathrm{kmh}^{-1}$ (d) desenvolvida durante a aquisição dos dados.

Figura 7.3 - Distribuição espacial da temperatura média do ar em ${ }^{\circ} \mathrm{C}$ (a), do desvio padrão (b) e dos valores máximos (c) e mínimos (d) observados em cada intervalo de amostragem.

Figura 7.4 - Distribuição espacial do fluxo Q* médio em $\mathrm{Wm}^{-2}$ (a), do desvio padrão (b) e dos valores máximos (c) e mínimos (d) observados em cada intervalo de amostragem.

Figura 7.5 - Distribuição espacial do fluxo $\mathrm{L}^{*}$ médio em $\mathrm{Wm}^{-2}$ (a), do desvio padrão (b) e dos valores máximos (c) e mínimos (d) observados com o pirgeômetro em cada intervalo de amostragem.

Figura 7.6 - Distribuição espacial dos fluxos $\mathrm{L} \downarrow$ médio (a), L个 (b), e dos fluxos estimados $\mathrm{L} \rightarrow$ (c) e $\leftarrow \mathrm{L}$ (d) emitidos pelas paredess dos canyons, $\mathrm{em} \mathrm{Wm}^{-2}$ para cada intervalo de amostragem.

Figura 7.7 - Distribuição espacial do fluxo L* estimado no nível do pirradiômetro (a) e da divergência vertical $-\nabla \cdot L^{*}$ estimada na camada próxima ao chão (b), em $\mathrm{Wm}^{-2}$ para cada intervalo de amostragem. Evolução diária da divergência $-\nabla \cdot L^{*}$ em termos do ritmo mensal (c) e do ritomo semanal (d). O polígono pontilhado em (b) envolve o centro expandido da cidade de São Paulo. 
Figura 7.8 - Evolução semanal da velocidade média desenvolvida durante os experimentos (a), com sugestão de um polinômio de quarta ordem interpolado, respectivo coeficiente quadrático de correlação e barras de erro representando o erro relativo. Evolução temporal da divergência $-\nabla \cdot L^{*}$ em termos do ritmo semanal (b), anual (c) e diário (d), com sugestão de ciclos senoidais interpolados.

Figura 7.9 - Evolução da distribuição espacial da concentração de material particulado $\left(\mu g m^{-3}\right)$ na região metropolitana de São Paulo nos anos de 2002 (a), 2003 (b), 2004 (d) e 2005 (c), sentido horário.

Figura 7.10 - Distribuição média da concentração de material particulado $\left(\mu \mathrm{gm}^{-3}\right)$ na região metropolitana de São Paulo, em termos de sua relação espacial para o período entre 2002 e 2005 (a) e em termos de sua relação

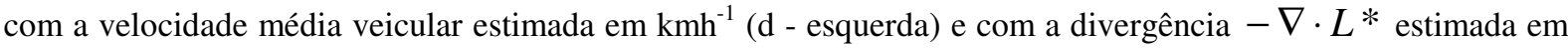
$\mathrm{Wm}^{-2}(\mathrm{~d}$ - direita). As barras de erro representam o desvio padrão. São sugeridas expressões polinomias e exponenciais para as relações em (d). Distribuição espacial da velocidade média veicular (b) e da divergência $-\nabla \cdot L^{*}(\mathrm{c})$, estimadas para o ano de 2007.

Figura 7.11 - Evolução da distribuição espacial da concentração de monóxido de carbono (ppm) na região metropolitana de São Paulo nos anos de 2002 (a), 2003 (b), 2004 (d) e 2005 (c), sentido horário.

Figura 7.12 - Distribuição média da concentração de monóxido de carbono (ppm) na região metropolitana de São Paulo, em termos de sua relação espacial para o período entre 2002 e 2005 (a) e em termos de sua relação com a velocidade média veicular estimada $\mathrm{em} \mathrm{kmh}^{-1}(\mathrm{~d}$ - esquerda) e com a divergência $-\nabla \cdot L *$ estimada em $\mathrm{Wm}^{-2}$ (d - direita). As barras de erro representam o desvio padrão. São sugeridas expressões polinomias de segunda e terceira ordem para as relações em (d). Distribuição espacial da velocidade média veicular (b) e da divergência $-\nabla \cdot L^{*}(\mathrm{c})$, estimadas para o ano de 2007.

Figura 7.13 - Evolução da distribuição espacial da concentração de ozônio $\left(\mu \mathrm{gm}^{-3}\right)$ na região metropolitana de São Paulo nos anos de 2002 (a), 2003 (b), 2004 (d) e 2005 (c), sentido horário.

Figura 7.14 - Distribuição média da concentração de ozônio $\left(\mu \mathrm{gm}^{-3}\right)$ na região metropolitana de São Paulo, em termos de sua relação espacial para o período entre 2002 e 2005 (a) e em termos de sua relação com a velocidade

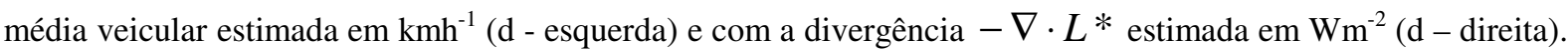
As barras de erro representam o desvio padrão. São sugeridas expressões polinomiais de terceira e quarta ordens para as relações em (d). Distribuição espacial da velocidade média veicular (b) e da divergência $-\nabla \cdot L^{*}$ (c), estimadas para o ano de 2007.

Figura 7.15 - Evolução da distribuição espacial da concentração de dióxido de enxofre $\left(\mu \operatorname{gm}^{-3}\right)$ na região metropolitana de São Paulo nos anos de 2002 (a), 2003 (b), 2004 (d) e 2005 (c), sentido horário.

Figura 7.16 - Distribuição média da concentração de dióxido de enxofre $\left(\mu \mathrm{gm}^{-3}\right)$ na região metropolitana de São Paulo, em termos de sua relação espacial para o período entre 2002 e 2005 (a) e em termos de sua relação

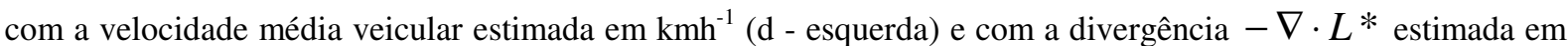
$\mathrm{Wm}^{-2}(\mathrm{~d}-$ direita). As barras de erro representam o desvio padrão. São sugeridas expressões polinomiais de 
terceira e quarta ordens para as relações em (d). Distribuição espacial da velocidade média veicular (b) e da divergência $-\nabla \cdot L^{*}(\mathrm{c})$, estimadas para o ano de 2007.

Figura 7.17 - Evolução da distribuição espacial da concentração de dióxido de nitrogênio $\left(\mu \operatorname{ggm}^{-3}\right)$ na região metropolitana de São Paulo nos anos de 2002 (a), 2003 (b), 2004 (d) e 2005 (c), sentido horário.

Figura 7.18 - Distribuição média da concentração de dióxido de nitrogênio $\left(\mu \mathrm{gm}^{-3}\right)$ na região metropolitana de São Paulo, em termos de sua relação espacial para o período entre 2002 e 2005 (a) e em termos de sua relação

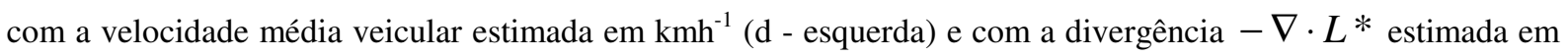
$\mathrm{Wm}^{-2}$ (d - direita). As barras de erro representam o desvio padrão. São sugeridas expressões polinomias de terceira e quarta ordens para as relações em (d). Distribuição espacial da velocidade média veicular (b) e da divergência $-\nabla \cdot L^{*}(\mathrm{c})$, estimadas para o ano de 2007.

Figura 7.19 - Evolução da distribuição espacial da concentração de monóxido de nitrogênio $\left(\mu \operatorname{gm}^{-3}\right)$ na região metropolitana de São Paulo nos anos de 2002 (a), 2003 (b), 2004 (d) e 2005 (c), sentido horário.

Figura 7.20 - Distribuição média da concentração de monóxido de nitrogênio $\left(\mu \mathrm{gm}^{-3}\right)$ na região metropolitana de São Paulo, em termos de sua relação espacial para o período entre 2002 e 2005 (a) e em termos de sua relação com a velocidade média veicular estimada em $\mathrm{kmh}^{-1}(\mathrm{~d}$ - esquerda) e com a divergência $-\nabla \cdot L *$ estimada em $\mathrm{Wm}^{-2}(\mathrm{~d}$ - direita). As barras de erro representam o desvio padrão. São sugeridas expressões polinomias de terceira ordem para as relações em (d). Distribuição espacial da velocidade média veicular (b) e da divergência $-\nabla \cdot L^{*}(\mathrm{c})$, estimadas para o ano de 2007.

Figura 7.21 - Evolução da distribuição espacial da concentração dos óxidos de nitrogênio (ppb), excetuando-se o NO e o $\mathrm{NO}_{2}$, na região metropolitana de São Paulo nos anos de 2002 (a), 2003 (b), 2004 (d) e 2005 (c), sentido horário.

Figura 7.22 - Distribuição média da concentração de óxidos de nitrogênio (ppb), exceto o $\mathrm{NO}$ e o $\mathrm{NO}_{2}$, na região metropolitana de São Paulo, em termos de sua relação espacial para o período entre 2002 e 2005 (a) e em termos de sua relação com a velocidade média veicular estimada em $\mathrm{kmh}^{-1}$ (d - esquerda) e com a divergência $-\nabla \cdot L^{*}$ estimada em $\mathrm{Wm}^{-2}(\mathrm{~d}-$ direita). As barras de erro representam o desvio padrão. São sugeridas expressões polinomiais de terceira ordem para as relações em (d). Distribuição espacial da velocidade média veicular (b) e da divergência $-\nabla \cdot L^{*}$ (c), estimadas para o ano de 2007.

Figura 8.1 - Cenas características das paredes de canyons urbanos encontradas durante os experimentos: Av.Pompéia (a), Av. Prof. Frederico Hermann Jr. (b), Rua Tito (c) e Rua Dardanelos (d). Os círculos indicam a área aproximada dos alvos definidos pelo ângulo de abertura do sensor IRT, posicionado em diferentes ângulos de elevação (ver Capítulo 3.3, item 1).

Figura 8.2 - Distribuição espacial (a, b) e amostral (c, d) da temperatura das paredes dos canyons obtidas com dois sensores IRT, posicionados à direita $(b, d)$ e à esquerda do veículo $(a, c)$. A linha vertical contínua $(a, b)$ delimita dois experimentos realizados em localidades distintas, à esquerda na Av. Paulista e à direita na Av. 
Pompéia. As linhas verticais pontilhadas delimitam trechos dos experimentos nos quais os sensores IRTs foram posicionados em diferentes ângulos de elevação.

Figura 8.3 - Distribuição espacial (a, b) e amostral (c, d) dos fluxos L $\uparrow$ emitidos pelas paredes dos canyons, estimados a partir das observações realizadas com os sensores IRTs posicionados à direita (b, d) e à esquerda do veículo $(\mathrm{a}, \mathrm{c})$. A linha vertical contínua $(\mathrm{a}, \mathrm{b})$ delimita dois experimentos realizados em localidades distintas, à esquerda na Av. Paulista e à direita na Av. Pompéia. As linhas verticais pontilhadas delimitam trechos dos experimentos nos quais os sensores IRTs foram posicionados em diferentes ângulos de elevação.

Figura 8.4 - Distribuição amostral da temperatura aparente das paredes dos canyons obtidas com os sensores IRTs posicionados à direita (b) e à esquerda (a). As colunas cinzas indicam o sensor posicionado a um ângulo de elevação de $0^{\circ}$, as pretas a $30^{\circ}$ e as brancas a $45^{\circ}$. Distribuição vertical (c) da temperatura média aparente, as barras indicam o erro relativo e as linhas contínuas sugerem um polinômio de segunda ordem que melhor representa esta distribuição.

Figura 8.5 - Distribuição temporal (a, b) e espacial (c, d) da temperatura média das paredes dos canyons durante o experimento na Av. Paulista (b, d) e o experimento na Av. Pompéia (a, c). As barras de erro indicam o desvio padrão. As linhas contínuas escuras representam a temperatura do ar observada durante os experimentos. As linhas verticais definem os trechos compreendidos pelas Avenidas. As setas indicam o sentido de deslocamento nestas vias.

Figura 8.6 - Distribuição amostral da temperatura aparente das paredes, para os canyons posicionados na direção zonal (a) ou na direção meridional (b). Distribuição da amplitude térmica entre as paredes e o ar em relação à amplitude térmica entre o piso do canyon e o ar (c), sugerindo-se os perfis polinomiais que melhor se adequam a estas distribuições (d). A distribuição cardeal das paredes é referenciada por um observador imaginário posicionado no interior do edifício, que observa para além das janelas. As áreas hachureadas (c, d) representam o intervalo onde prevalecem as cenas mistas entre paredes e céu.

Figura 8.7 - Distribuição amostral da temperatura do ar, do piso, no interior do veículo e sobre a superfície das faces sul (a) e norte (b).

Figura 8.8 - Distribuição amostral da temperatura aparente do piso dos canyons meridionais (a) e zonais (b).

Figura 8.9 - Distribuição da temperatura observada no interior do veículo em relação à temperatura das paredes mais altas (esquerda), à temperatura do ar (centro) e à temperatura do piso (direita). As linhas pontilhadas indicam a correlação linear perfeita.

Figura 8.10 - Distribuição do fluxo L $\downarrow$ médio em relação à temperatura das paredes (a, c), das cenas mistas (b, e) e do ar (c, f)., observado durante os experimentos na Av. Paulista (a, b, c) e na Av. Pompéia (d, e, f). As barras representam o desvio padrão. As linhas contínuas indicam os polinômios de quarta ordem que melhor se ajustam. Os índices de correlação são representados por R e as emissividades estimadas por $\varepsilon$. 
Figura 8.11 - Imagem SPOT do município de São Paulo (a). O polígono branco delimita a região central da cidade (b). Distribuição espacial dos fluxos $\mathrm{L}^{*}(\mathrm{c}), \mathrm{Q}^{*}(\mathrm{~d})$ e $\mathrm{Q}_{\mathrm{H}}(\mathrm{e})$ em $\mathrm{Wm}^{-2}$, e da pressão de vapor (f) estimada em hPa.

Figura 8.12 - Imagem SPOT do município de São Paulo (a). O polígono branco delimita a região do Parque do Ibirapuera e Jardins em direção à várzea do Pinheiros (b). Distribuição espacial dos fluxos L* (c), Q* (d) e $Q_{H}$ (e) em $\mathrm{Wm}^{-2}$, e da pressão de vapor (f) estimada em hPa.

Figura 8.13 - Imagem SPOT do município de São Paulo (a). O polígono branco delimita a região da Marginal Tietê que abrange a confluência do Tamanduateí em direção à várzea do Carmo (b). Distribuição espacial dos fluxos $L^{*}(c), Q^{*}(d)$ e $Q_{H}(e)$ em $W^{-2}$, e da pressão de vapor (f) estimada em $h P a$.

Figura 8.14 - Imagem SPOT do município de São Paulo (a). O polígono branco delimita a região do Jabaquara, abrangendo o entroncamento com a Bandeirantes ao sul e estendendo-se a leste pelos bairros do Ipiranga e da Saúde (b). Distribuição espacial dos fluxos $\mathrm{L}^{*}(\mathrm{c}), \mathrm{Q}^{*}(\mathrm{~d})$ e $\mathrm{Q}_{\mathrm{H}}(\mathrm{e})$ em $\mathrm{Wm}^{-2}$, e da pressão de vapor (f) estimada em hPa.

Figura 8.15 - Imagem SPOT da área em torno à Av. Queiroz Fo. (centro), entre a Av. Diógenes Ribeiro de Lima (A) e a Av. Imperatriz Leopoldina (B). As linhas contínuas representam os trajetos percorridos e correspondem às pistas norte e sul. Os polígonos tracejados delimitam dois setores com ocupações distintas, ao setor oriental correspondem as imagens adjacentes abaixo, enquanto ao setor ocidental correspondem as imagens adjacentes acima. As imagens acima e abaixo também possuem uma correspondência mútua, da esquerda para a direita representam respectivamente a visão do nadir, a visão do zênite, a visão da face sul e a visão da face norte.

Figura 8.16 - Distribuição espacial do balanço radiativo observado na Av. Queiroz Fo., entre os pontos B e A representados na Fig. 8.15, em torno das 8 h e 15 min de uma manhã de domingo no outono (linha contínua central), e em torno das $21 \mathrm{~h}$ e $52 \mathrm{~min}$ de uma noite de quarta-feira no inverno (linha tracejada abaixo). As linhas contínuas mais acima e mais abaixo representam, respectivamente, a componente de onda curta estimada para este balanço $\left(\mathrm{K}^{*}\right)$ e a componente de onda longa observada para este balanço $\left(\mathrm{L}^{*}\right)$. As imagens acima indicam cenas não simultâneas do nadir e do zênite para as posições correspondentes ao gráfico.

Figura 8.17 - Distribuição espacial da temperatura das paredes observadas na Av. Queiroz Fo., entre os pontos B e A representados na Fig. 8.15, em torno das 8 h e 15 min de uma manhã de domingo no outono (linhas contínuas), e em torno das $21 \mathrm{~h}$ e $52 \mathrm{~min}$ de uma noite de quarta-feira no inverno (linhas tracejadas). As linhas acima representam as paredes que compõem a face sul, enquanto as linhas abaixo representam as paredes que compõem a face norte. As imagens acima e abaixo indicam, respectivamente, cenas não simultâneas da face sul e da face norte para as posições correspondentes ao gráfico. Áreas hachureadas nos gráficos indicam a amplitude da temperatura do ar observada entre as duas situações estudadas. 


\section{Lista de tabelas}

Tabela 2.1 - Máscara para localização relativa à Figura 2.3.

Tabela 2.2 - Máscara para localização relativa às Figuras 2.4 e 2.5.

Tabela 2.3 - Máscara para localização relativa à Figura 2.6.

Tabela 2.4 - Representação escalar abrangente da fenomenologia meteorológica e sua relação com os efeitos climáticos urbanos. Em destaque as seguintes concepções: teórica de Orlanski (hachureado sólido), empírica (hachureado sólido e horizontal) e teórica de Monteiro (hachureado sólido, horizontal e diagonal).

Tabela 4.1 - Frequiência temporal dos experimentos realizados, em relação ao dia da semana, às atividades humanas e aos períodos horários.

Tabela 4.2 - Representação temporal dos experimentos realizados, em relação ao dia da semana, aos instantes de saída e chegada do laboratório móvel e à distância percorrida durante cada travessia.

Tabela 5.1 - Distribuição de amostragem dos lugares visitados com maior freqüência.

Tabela 5.2 - Distribuição de amostragem dos 313 principais lugares visitados. São reconhecidos alamedas ( $\mathrm{Al}$ ), avenidas (A), bairros (B), cemitérios (Cem), colégios (Col), elevados (Elev), estádios, (Est), expressos (Exp), favelas (Fav), garagens (G), hospitais (Hosp), jardins (J), largos (L), marginais (M), municípios (Mun), parques $(\mathrm{P})$, pontes e viadutos $(\mathrm{Pt})$, praças $(\mathrm{Pç})$, rodovias $(\mathrm{Rod})$, ruas $(\mathrm{R})$, shopping centers (Shop), travessas $(\mathrm{Tr})$, trevos (Trev), túneis (T) e algumas localidades notáveis.

Tabela 6.1 - Emissividades estimadas e observadas.

Tabela 8.1 - Fluxos L* (onda longa), $Q^{*}$ (multi-espectral) e $\mathrm{K}^{*}$ (onda curta) médios observados e estimado, acompanhados dos respectivos erros relativos e associados a diferentes tipos de ocupação do solo. 


\section{Símbolos}

Símbolo

Quantidade

Unidades SI

Letras romanas maiúsculas

C Coordenadas em um instante qualquer do percurso UTM

$\mathrm{C}_{0} \quad$ Coordenadas iniciais do percurso

UTM

CI Índice de claridade

$\mathrm{F}_{\mathrm{cld}} \quad$ Fração do céu coberto por nuvens

$\mathrm{G}^{\mathrm{D}} \quad$ Fluxo genérico de energia sobre um domínio

$\mathrm{W} \mathrm{m}{ }^{-2}$

diversificado

$\mathrm{G}_{\mathrm{i}} \quad$ Fluxo genérico de energia sobre uma unidade específica $\quad \mathrm{W} \mathrm{m}^{-2}$ do domínio

H Coeficiente de proporcionalidade para correção do sensor

IRT

$\mathrm{I}_{\mathrm{ex}}$

Constante solar

$\mathrm{W} \mathrm{m}{ }^{-2}$

K Coeficiente de proporcionalidade para correção do sensor

IRT

\begin{tabular}{|c|c|c|}
\hline $\mathrm{K}^{*}$ & Saldo radiativo em ondas curtas & $\mathrm{W} \mathrm{m}^{-2}$ \\
\hline $\mathrm{K} \downarrow$ & Radiação incidente em ondas curtas & $\mathrm{W} \mathrm{m} \mathrm{m}^{-2}$ \\
\hline $\mathrm{K} \downarrow_{\text {claro }}$ & Radiação incidente em ondas curtas sob céu claro & $\mathrm{W} \mathrm{m}{ }^{-2}$ \\
\hline $\mathrm{K} \uparrow$ & Radiação refletida em ondas curtas & $\mathrm{W} \mathrm{m^{-2 }}$ \\
\hline $\mathrm{L}^{*}$ & Saldo radiativo em ondas longas & $\mathrm{W} \mathrm{m}^{-2}$ \\
\hline $\mathrm{L} \downarrow$ & $\begin{array}{l}\text { Radiação incidente em ondas longas a partir do } \\
\text { hemisfério zenital }\end{array}$ & $\mathrm{W} \mathrm{m^{-2 }}$ \\
\hline $\mathrm{L}_{\mathrm{a}} \downarrow$ & $\begin{array}{l}\text { Radiação incidente em ondas longas proveniente da } \\
\text { atmosfera }\end{array}$ & $\mathrm{W} \mathrm{m}^{-2}$ \\
\hline$L \downarrow_{\zeta}$ & $\begin{array}{c}\text { Radiação incidente em ondas longas a partir de um } \\
\text { ângulo zenital }\end{array}$ & $\mathrm{W} \mathrm{m}^{-2}$ \\
\hline $\mathrm{L} \uparrow$ & Radiação em ondas longas emitida a partir de uma & $\mathrm{W} \mathrm{m^{-2 }}$ \\
\hline
\end{tabular}


superfície

$\mathrm{L} \uparrow_{\mathrm{EL}} \quad$ Radiação em ondas longas emitida no nível do $\quad \mathrm{W} \mathrm{m}^{-2}$ radiômetro Eppley

$\mathrm{L} \uparrow_{\mathrm{KZ}} \quad$ Radiação em ondas longas emitida logo abaixo do
radiômetro Kipp-Zonen
$\mathrm{P} \quad$ Coeficiente de proporcionalidade para correção do sensor IRT

Q* $\quad$ Saldo da densidade de fluxo radiativo para todo o $\mathrm{W} \mathrm{m}{ }^{-2}$ espectro

Q* ${ }_{\text {HB }} \quad$ Saldo da densidade de fluxo radiativo sobre o corpo $\quad \mathrm{W} \mathrm{m}^{-2}$ humano

$\mathrm{Q}_{\mathrm{E}} \quad$ Densidade do fluxo turbulento associado ao calor latente $\quad \mathrm{W} \mathrm{m}^{-2}$

$\mathrm{Q}_{\mathrm{F}} \quad$ Densidade do fluxo antropogênico associado ao calor $\quad \mathrm{W} \mathrm{m}^{-2}$ devido à combustão

$\mathrm{Q}_{\mathrm{G}} \quad$ Densidade do fluxo associado ao calor sub-superficial $\quad \mathrm{W} \mathrm{m}^{-2}$

$\mathrm{Q}_{\mathrm{H}} \quad$ Densidade do fluxo turbulento associado ao calor $\quad \mathrm{W} \mathrm{m}^{-2}$ sensível

Q $\quad$ Densidade do fluxo associado ao calor metabólico $\quad \mathrm{W} \mathrm{m}^{-2}$

S Densidade do fluxo associado ao calor dissipado por $\quad \mathrm{W} \mathrm{m}^{-2}$ fontes diversas

Coeficiente de sensibilidade do pirgeômetro $\mathrm{mV} \mathrm{W}^{-1} \mathrm{~m}^{-2}$

$\mathrm{T}_{\mathrm{a}} \quad$ Temperatura do ar próximo à superfície $\quad \mathrm{K},{ }^{\circ} \mathrm{C}$

$\mathrm{T}_{\mathrm{ap}} \quad$ Temperatura do pirgeômetro $\quad \mathrm{K},{ }^{\circ} \mathrm{C}$

$\mathrm{T}_{\text {ceu }} \quad$ Temperatura aparente do céu (atmosfera + nuvem) $\quad \mathrm{K},{ }^{\circ} \mathrm{C}$

$\mathrm{T}_{\mathrm{o}} \quad$ Temperatura no piso do canyon $\quad \mathrm{K},{ }^{\circ} \mathrm{C}$

$\mathrm{UR}_{\mathrm{a}} \quad$ Umidade relativa do ar próximo à superfície

Z Ângulo

Letras romanas minúsculas

$\mathrm{a}_{\mathrm{i}} \quad$ Área de uma unidade do domínio

$\mathrm{m}^{2}$ 
c

$\cos$

$\mathrm{e}_{\mathrm{a}}$

$\mathrm{e}_{\mathrm{sa}}$

$\mathrm{i}$

$\mathrm{t}$

$\mathrm{t}_{0}$

$\mathrm{u}$

W

Z

Fração da radiação absorvida por uma superfície

Calor específico

Função co-seno

Pressão de vapor

Valor de saturação da pressão de vapor

Indexador genérico

Instante genérico em um percurso

Instante inicial de um percurso

Espessura óptica da atmosfera para o vapor d'água

Conteúdo de água "precipitável” na atmosfera

Cota
$\mathrm{J} \mathrm{kg}^{-1} \mathrm{~K}^{-1}$

$\mathrm{Pa}$

$\mathrm{Pa}$

S

S

$\mathrm{mm}$

$\mathrm{mm}$

$\mathrm{m}$

Letras gregas maiúsculas

$\Delta \mathrm{Q}_{\mathrm{A}} \quad$ Variação do fluxo de energia advectado (sensível e $\quad \mathrm{W} \mathrm{m}^{-2}$ latente)

$\Delta \mathrm{Q}_{\mathrm{S}} \quad$ Variação da energia armazenada $\quad \mathrm{W} \mathrm{m}^{-2}$

$-\nabla_{h} \cdot L^{*} \quad$ Divergência radiativa em ondas longas $\quad \mathrm{W} \mathrm{m}^{-3}$

Letras gregas minúsculas

$\alpha$

$\alpha_{0}$

$\beta$

$\frac{\partial C}{\partial t} \quad$ Variação local das coordenadas durante um percurso

$\varepsilon_{\mathrm{a}} \quad$ Emissividade do ar próximo à superfície

$\varepsilon_{\text {ceu }}$

$\varepsilon_{\text {claro }}$

$\varepsilon_{\text {nuvem }}$

Albedo superficial

Coeficiente de proporcionalidade

Albedo no piso do canyon

Coeficiente de proporcionalidade

Emissividade do céu (atmosfera + nuvens)

Emissividade do céu claro

Emissividade da nuvem

$\mathrm{m} \mathrm{s}^{-1}$ 
$\varepsilon_{\mathrm{o}}$

$\zeta$

$\theta$

$\lambda$

$\pi$ Razão entre o comprimento de uma circunferência e seu diâmetro

$\sigma$

$\tau_{\text {aer }}$

$\tau_{\mathrm{pg}} \quad$ Transmissividade solar atmosférica em relação aos gases permanentes

$\tau_{\mathrm{r}}$

$\tau_{\mathrm{w}}$

Transmissividade solar atmosférica em relação aos

aerossóis

solar atmosférica em relação ao

espalhamento Raleigh

Transmissividade solar atmosférica em relação ao vapor Constante de Stefan-Boltzmann

Emissividade superficial no piso do canyon

Ângulo zenital

Posição longitudinal

UTM

UTM

$\mathrm{W} \mathrm{m}^{-2} \mathrm{~K}^{-4}$

d'água 
Introdução 


\section{OBJETO, OBJETIVO E HIPÓTESES}

O objeto de estudo desta tese é o fluxo de energia na sua forma radiativa, especialmente aquela correspondente à banda do infravermelho termal, na faixa das ondas longas do espectro eletromagnético.

Esta pesquisa tem como objetivo verificar a variabilidade espacial da magnitude do fluxo radiativo em ondas longas, na região metropolitana da cidade de São Paulo.

A região metropolitana apresenta uma área urbanizada com ocupação de solo muito heterogênea. Estas diferentes ocupações de solo apresentam conseqüentemente diferentes propriedades físicas.

Considerando-se o ciclo diurno, setores densamente edificados e poluídos devem apresentar amplitudes térmicas mais elevadas. Enquanto setores arborizados e menos poluídos devem apresentar amplitudes reduzidas.

Um padrão térmico distinto da atmosfera e das diversas superfícies implica em trocas de energia. Estas trocas de energia dão-se através de fluxos condutivos, convectivos e radiativos.

Esses fluxos radiativos são de dois tipos, os de onda curta com origem em uma fonte natural solar, e os de onda longa com origem tanto em fontes naturais como também em fontes antrópicas.

As ondas longas emitidas na faixa do infravermelho termal estão diretamente relacionadas com o estado térmico das superfícies e constituintes do meio ambiente.

Atualmente, existem sensores de radiação termal suficientemente precisos, capazes de detectar indiretamente e de maneira mais fidedigna os padrões térmicos que compõem o intrincado ambiente urbano.

Como esses sensores apresentam custo relativamente elevado, idealizou-se uma plataforma móvel que, observadas as limitações associadas à variabilidade temporal do fenômeno estudado, pode resultar em um panorama espacial dos fluxos radiativos em ondas longas.

Portanto, surgem duas hipóteses fundamentais a serem verificadas. Primeiramente a existência de uma distribuição espacial complexa dos fluxos radiativos na camada abaixo das coberturas, muito distinta da aparente homogeneidade verificada acima e ditretamente 
vinculada à distribuição dos tipos de ocupação. Em segundo lugar, a utilização de observações diretas do fluxo em ondas longas como um indicador muito mais preciso da configuração térmica estabelecida, ao contrário das observações unicamente expressas pela temperatura do ar, que na realidade são representativas de um caráter demasiadamente homogeneizador.

\section{APRESENTAÇÃO}

O corpo deste trabalho divide-se em três secções. Divisão que busca conduzir o leitor, de maneira didática, desde o processo de sistematização científica que compõe o procedimento de elaboração do projeto que conduziu a esta tese, considerando-se inclusive a própria natureza intuitiva dos primeiros passos, até o processo de análise científica através do qual o método é discutido e os resultados visualizados.

A secção 1 explana a natureza do fenômeno no meio urbano, sua diversidade e as motivações em estudá-lo.

A secção 2 descreve o método e sua aplicação ao estudo do clima urbano.

A secção 3 delineia alguns aspectos essenciais, os quais promovem a compreensão da distribuição dos fluxos radiativos na cidade, mesmo além das ondas longas e da distribuição espacial, também reconhecendo a existência de uma natureza distributiva temporal e amostral, que envolve outros elementos do clima urbano relevantes para o balanço dos fluxos de energia na metrópole.

As secções 2 e 3 combinam-se para constituir o arcabouço da análise científica, inicialmente a

partir da exploração dos fundamentos que são imprescindíveis para tal e, posteriormente, já sob posse de alguns resultados relevantes, a uma etapa reflexiva mais profunda na qual resultados detalhados são avaliados em busca de um caminho conclusivo. 


\section{TRAJETÓRIA DO AUTOR}

Ainda me recordo da sensação de frio quando me prostrava naquele piso de cimento gélido, empunhando alguns lápis coloridos e desenhando sobre uma cartolina branca a origem do planeta Terra. Eu tinha sete anos de idade e tentava reproduzir aquelas ilustrações e textos maravilhosos que encontrava nos belos livros que meu pai sempre gentilmente me presenteava desde minha mais remota idade. Nesta época já contava com o apoio e incentivo decisivos da querida Prof ${ }^{a}$ Maria Aparecida de Toledo Machado, quem me acompanhou pelos quatro anos iniciais do ensino fundamental.

O interesse científico permaneceu latente até o primeiro ano do ensino médio, quando me afloraria de forma vigorosa. Neste momento eu iniciava meus estudos no Colégio São Luís, graças a uma bolsa de estudos praticamente integral com que fui agraciado pelos jesuítas da Companhia de Jesus, aos quais serei sempre eternamente grato. Neste tradicional colégio da cidade de São Paulo tive a satisfação de conhecer meus melhores professores. Homens que sabiam muito além de ensinar, semear na alma de seus alunos uma gana inesgotável pela busca ao saber. No entanto, os meses iniciais foram de profunda súplica. Meu boletim escolar ainda é testemunha das mazelas pelas quais passei durante a transição. Era uma sucessão de notas vermelhas, com exceção de um único dez que despontava. O dez em Geografia, a disciplina que sempre me apaixonou e a qual sempre tive como amparo nos momentos mais difíceis. Mas a jornada foi pródiga, apaixonei-me por outras disciplinas, História, Filosofia, e aprendi a gostar de Química, Física e a terrível Matemática, sempre meu eterno calcanhar de Aquiles. A domesticação de minha fraqueza me faria optar em seguir de modo instigante o caminho das ciências exatas, indo até o meu limite.

Mas de todas as matérias estudadas, uma fascinou-me a tal ponto que abracei como carreira. Como não poderia ser diferente, foi estudada no âmbito da Geografia. Recordo-me das aulas sobre os climas da Terra, o tropical, o temperado, o mediterrâneo, proferidas de forma irretocável pelo querido Prof. e geógrafo Nélson Basic Olic. Sim, era isto que eu queria. Mas haveria clima na área de exatas? Aparentemente havia algo semelhante, o curso de Bacharelado em Meteorologia. E sob críticas de muitos colegas resolvi seguir esta carreira.

Graduei-me e obtive título de Mestre em Ciências na área de Meteorologia, sob a orientação da $\operatorname{Prof}^{a}$ Dr $^{a}$ Maria Assunção Faus da Silva Dias. Minha pesquisa na iniciação científica até o mestrado versou desde o trabalho observacional em campo até a modelagem numérica. Posteriormente, como funcionário da Universidade de São Paulo, trabalhei durante dez anos 
no mesmo Departamento no qual me graduei. Desempenhei diversas atividades, da área de informática à área meteorológica, que propriamente me interessava. Na metade final deste período trabalhei com afinco gerenciando uma plataforma radiométrica fixa, sob a supervisão do companheiro Prof. Dr. Amauri Pereira de Oliveira.

Essa etapa foi decisiva. Após vagar por diversos meandros da Meteorologia e conhecer quase todas as suas sub-áreas, pude aprimorar meus conhecimentos técnicos e iniciar o resgate do espírito observador.

Sem perceber, estava me reencontrando, reencontrando a Geografia, e encontrando o Prof. Dr. Tarik Rezende de Azevedo, que se tornaria meu orientador nesta nova página que escrevo a partir de agora.

São Paulo

A. J. M.

Outono de 2009 


\section{CLIMATOLOGIA COMO FRONTEIRA CIENTÍFICA}

\section{a) Introdução a um ensaio entre meteorologia e geografia}

Grimmond e Oke (2002), em um esforço de parametrização dos fluxos de energia em uma área urbana, idealizam um esquema no qual surge nitidamente um limiar entre meteorologia e geografia. Talvez, mais modestamente, um limiar entre uma concepção de ciência meteorológica e outra concepção de ciência geográfica. Todavia, poderia servir de ponto de partida para uma reflexão mais profunda.

Segundo a concepção da escola de Oke, no limiar entre as duas ciências estão os fluxos de energia e os parâmetros de rugosidade para os escoamentos de massa. Em um diagrama vertical idealizado (GRIMMOND e OKE, 2002) a ciência meteorológica é representada acima, através dos métodos de observação das propriedades físicas do ar. Propriedades como temperatura, conteúdo de umidade, precipitação, vento e radiação solar (que por si só já é um fluxo de energia) são consideradas. Abaixo do limiar está a ciência geográfica representada pelos sistemas de informação da cobertura superficial. Estes sistemas contém informações de origem observacional, que dizem respeito às frações de cobertura e suas propriedades radiativas e rugosas.

A procura de um limiar entre estas duas ciências tem atualmente um significado bastante prático, associado às disputas profissionais. No caso desta disputa anunciada, parece surgir como matéria da discórdia as disciplinas climatológicas, sob suas diversas denominações, climatologia geográfica, estocástica, física, e assim por diante.

Em meio à profusão de diversos procedimentos de pesquisa e a sua apropriação por ambas as ciências, associada à alienação por parte de estudantes e pesquisadores em relação à história destas ciências, a discórdia parece assumir feições de disputas legais, aliás, já não exclusividade apenas destas duas ciências.

Uma trégua poderia ser anunciada, e uma visão de um esboço histórico da disciplina geográfica talvez fosse em alguma medida revelador. Por exemplo, o curso de bacharelado em meteorologia da Universidade de São Paulo é ministrado por uma de suas conceituadas unidades, a qual foi originalmente incorporada na década de 30 como órgão complementar a 
partir de seu embrião, a Comissão Geográfica e Geológica de São Paulo, por sua vez criada na segunda metade do séc. XIX (ARAÚJO, 2005).

O desenvolvimento da ciência meteorológica parece ter raízes fincadas na ciência geográfica. O desvirtuamento desta evolução progressiva, e a conseqüente ruptura entre estas ciências parece ter ocorrido definitivamente na década de 70. Por um lado pela desqualificação do que se denominava geografia quantitativa e seus desdobramentos, por outro lado pelo surgimento de uma escola meteorológica nacional cunhada a partir das relações com a escola norteamericana, onde estavam sob grande difusão as ferramentas de modelagem numérica, possibilitadas pelos avanços computacionais.

Cabe, portanto, um pensar que vai além da consideração cataclísmica de que cada profissional faz de uma área de investigação científica o que bem entende por princípios a ela associados. Para isto, talvez uma discussão aproximada apenas ao âmbito científico não seja suficiente. Uma reflexão que envolva a esfera filosófica seria mais adequada. Além disso, poder-se-ia englobar mesmo considerações de tratamento mítico. Pois é preocupante, como nos estudos contemporâneos se levanta, no horizonte das perspectivas, o personalismo das lideranças temáticas e a celebração quase cega de ferramentas de investigação, em essência, instrumentos prospectivos confundidos com a própria realidade da Natureza e da Sociedade.

O fruto dessa postura pode dizer respeito às próprias concepções culturais. Através da criação de novas ordens simbólicas e de conjuntos de práticas materializadas pelo trabalho, desnaturaliza-se a Natureza criando-se a existência social. Não se trata exatamente de um processo de desnaturização ou de idealizar-se uma segunda natureza, mas "simplesmente reconhecer à existência de uma alteridade entre Natureza e Sociedade, que como entes coletivos estão postos no mundo" (CHAUÍ, 2005, p. 52-53).

Assim como a Sociedade, a Natureza é elemento fundador da investigação geográfica. Através da crítica kantiana, absorvida pelos filósofos da natureza desde o início do séc. XIX são estabelecidas as bases da Geografia Física moderna (VITTE, 2006). Que em respeito a esta reflexão, seria, por sua vez, o embrião da Meteorologia moderna, a partir dos estudos de Humboldt e seus seguidores, especialmente no que diz respeito à análise espacial topográfica a partir de sua relação com os campos barométricos horizontais.

Os cientistas da natureza estabelecem de maneira contundente os princípios da investigação, com base na observação da realidade. Atualmente, no entanto, a profusão de diversos modelos estocásticos, escalares e, sobretudo, numéricos, vinculados a somas vultuosas de recursos, tem 
marginalizado a investigação por observação ou mesmo os estudos de casos que põem à prova as teorias estabelecidas. Curiosamente, os próprios modelos são suscetíveis a testes de sensibilidade, cujos resultados também são limitados a modos específicos do fenômeno. Cada escola, grupo ou pesquisador tem experimentado o seu modo. O modelo assume proporções poderosas perante a realidade. O limite aristotélico entre filosofia e ciência na busca da explicação do mundo real é substituído pelo mito modelado.

A importância do modelo reside em nortear a prospecção, mas não deve ser encarado como a realidade última. É possível traçar um paralelo às concepções míticas da vida nas sociedades primitivas, mediante as suas experiências de vida (CAMPBELL, 2001) e os determinismos impostos em diversos meios, em relação à sociedade científica que hoje predomina. Mais do que procurar um sentido para a investigação do fenômeno, dever-se-ia buscar uma experiência da própria existência do fenômeno, com ressonância no ser da pesquisa e no ser da própria realidade, e verificar se estes se coadunam em harmonia, para que um próximo passo seja projetado.

Surgem indícios de que haja também uma ansiedade veemente na busca de renovação do método científico. Semelhante à ocorrida aos artistas renascentistas, que em busca da renovação da arte voltaram-se para a Natureza e para a Ciência (GOMBRICH, 1999, p. 235). Talvez esta fosse uma justificativa mais genuína.

Mas enfim, qual seria o fundamento que poderia reger ou mesmo contribuir para uma definição dos limites entre as duas ciências em questão? A despeito de todas as discussões que podem envolver os métodos (e este será definido a seguir) parece existir algo mais fundamental que poderia definir o lugar das duas ciências.

As duas ciências abordam as características espaciais e temporais dos fenômenos não apenas com profusão de métodos, mas também de escalas. As discussões escalares seriam mais fundamentais, pois limitariam o próprio método. Tanto a ciência geográfica (MONTEIRO,1975) como a ciência meteorológica (ORLANSKI, 1976) têm se debruçado sobre esta questão, e uma série de escalas espaciais e temporais têm sido definidas. Aliás, a própria escala do movimento emerge como diretamente vinculada à determinação das duas anteriores.

Seria, talvez, na definição das escalas que melhor se definiria o campo de atuação destas áreas de investigação. Tendo-se por fim a concretização das diretrizes que estabeleceriam uma 
atuação coerente dos profissionais de ambas as áreas. Sendo possível, quem sabe, extrapolar este princípio para outros ramos do conhecimento científico.

Mas a relação é muito mais complexa, e as experiências de vida individuais em meio à criatividade inconsciente poderiam fazer emergir outros elementos preponderantes para a existência nesta relação. A análise escalar dos eventos meteorológicos em si poderia esclarecer em torno de que escala estaria mais proximamente vinculada a relação homemmeio, e qual estaria vinculada à existência do puramente meteorológico. O próprio significado léxico na expressão ta meteora (ARISTÓTELES, séc. IV a.C.) pode dar uma pista de sua fundamentação aristotélica, como o que se encontra distante. Mas distante de quê? Já arriscando uma resposta imediata, talvez da própria relação fundamental entre homem e meio, ou sociedade e natureza.

As atividades humanas podem e devem ter conseqüências sobre a evolução destes fenômenos. Mas quando se supõem tais consequiências, já está partindo-se propriamente para a relação, que é complexa, e não é resultado de uma ação pura e simples sobre o clima. Pois este, como tudo no mundo, modifica-se, e não apenas pela ação humana local, mas também por uma ação do meio regional e da própria evolução planetária global (LOWRY, 1977).

Voltando-se mais uma vez para a climatologia, que tudo indica realmente estar no limiar entre as duas ciências, vale observar a definição de clima aplicada pelos meteorologistas: padrão médio resultante dos diversos padrões espaciais e temporais combinados entre os diversos elementos do tempo meteorológico, em uma região que pode ser reconhecida sob diversas escalas. Observe-se ainda a própria definição de normal climatológica, definida pela Organização Meteorológica Mundial.

Mas se o clima é efetivamente - e pelas mudanças globais tão apregoadas no mundo contemporâneo tudo indica ser - um ente posto no mundo, deve-se observar que este ente é posto pelo homem, e para o homem.

Ora, mas se é um ente para o homem, a Geografia parece ir além da mera especulação dos elementos físicos da atmosfera, sob uma base estatística. Este ente, o clima, deve ir além em sua definição complexa de ser, agregando como essência talvez mais fundamental a própria biologia do humano. Pois é ente ideal, que na verdade relaciona o físico da atmosfera para o físico do corpo humano. E em seus desdobramentos vem condicionando, por toda a existência humana, as formas eleitas pelo homem de adaptabilidade pelo território planetário. 
Neste aspecto particular, a questão escalar do meio e uma definição de clima mais próxima à realidade humana parecem amalgamar-se muito bem em Sorre (2006), onde são lançados os princípios que podem contribuir para melhor entender até onde vai o clima meteorológico e onde começa o clima geográfico. Estes princípios levam em consideração o seguinte: “as escalas devem guardar os valores numéricos críticos para as funções orgânicas, a definição de clima deve abranger os elementos que agem sobre o organismo, estes elementos devem ser obrigatoriamente interativos, uma classificação climática só possui sentido se acompanhar a realidade viva, e, por fim, a essencialidade do fator duração na definição do clima”.

E agora retornando mais uma vez ao meio, o outro elo da relação, é possível eleger a cidade como o meio ideal para esta reflexão. A cidade contemporânea é o local onde se aglomera a maior parcela da população global. Sua metamorfose arquitetônica implica uma sucessão de climas sob diversas escalas de duração. Em Landsberg (2006) os efeitos da metamorfose superficial, sobre o ente ideal aqui colocado em questão, são intensamente escrutinados sempre em base dos diversos elementos atmosféricos.

Apesar do trabalho de Landsberg ser anterior ao de Lowry, já se impõe uma questão escalar que seria aprofundada pelo segundo autor. A variabilidade espacial e temporal dos elementos climáticos, o efeito da cidade, sua topografia e sua localização.

O grande problema é que a manifestação dos fenômenos dá-se simultaneamente em escalas completamente distintas. Há vento, sim, mas há vento em diversas escalas em um mesmo instante qualquer; ciclones, brisas e turbilhões, apenas para mencionar um aspecto.

Além disso, a questão da localização do ambiente, onde homem e meio se relacionam é aqui também complexa. Desde Landsberg e passando pela vasta escola Okeana, já a partir da década de 70, o ambiente urbano vem sendo esmiuçado em suas singularidades (OKE,1987). Mas em geral, não um ambiente urbano qualquer, mas aquele localizado entre as altas e médias latitudes.

Antes mesmo de preocupar-se com a localização mais específica dos entes do meio em uma área metropolitana, cabe lembrar a relevância destes estudos quando a cidade localiza-se em latitudes mais baixas. Muito que se conhece sobre os padrões climáticos provém de uma realidade que não é exatamente a realidade das populações nos trópicos. E aqui se deve observar que não se trata apenas das características físicas do clima, mas das próprias atividades humanas e conseqüentemente de suas distintas relações de trabalho. 


\section{b) Crítica aos métodos de estudos climáticos}

O método idealizado para este ensaio fundamenta-se em dois aspectos a priori distintos e suas possíveis interações. Inicialmente a consideração do ritmo das atividades humanas (AZEVEDO, 2001) desenvolvidas na Região Metropolitana de São Paulo e sua influência sobre as características climáticas no domínio deste território. E posteriormente o reconhecimento de um ser geográfico (MARTINS, 2007), que encaminhe a discussão para uma vertente filosófica, além de sua vertente científica já razoavelmente explicitada na introdução deste ensaio.

Pois, ao que parece, o desenvolvimento da ciência climatológica, no âmbito das ciências geográficas e em conformidade com a tradição Sorreana, tem privilegiado uma realidade muito mais próxima ao ser humano. O que interessa em uma primeira aproximação é o clima na camada abaixo das coberturas urbanas (Urban Canopy Layer - UCL), onde habitam e onde é o lugar da existência dos seres humanos (MACHADO e AZEVEDO, 2002).

Em verdade, os aspectos parecem estar inevitavelmente relacionados. De um lado está o meio no qual está inserido o humano, representado pelo ritmo das atividades, em especial o ritmo semanal que tudo indica melhor representar o seu período de evolução. Do outro, o próprio humano, reconhecido através de sua especificação geográfica.

Como instrumentos, foram empregues nesta pesquisa em primeiro lugar os conceitos escalares de clima para a cidade de São Paulo (TARIFA e ARMANI, 2001), reconhecendo-se em particular a topoescala como de preponderante interesse. Trata-se especificamente da escala do lugar, a escala que parece melhor reunir e detalhar o conjunto das atividades humanas através do território metropolitano.

Em segundo lugar, a utilização de radiômetros e sensores de temperatura, tendo-se aqui por princípio a conceituação apresentada por Grimmond e Oke (2002) como o limite entre a Geografia e a Meteorologia. Ou seja, a observação dos padrões térmicos no ambiente urbano e sua quantificação através de fluxos de energia parecem estar em acordo com este princípio.

Todavia, os sensores não dispostos em uma estrutura fixa, como em uma torre, por exemplo, em uma localidade específica. Como é a prática comum aceita pelas ciências meteorológicas.

Nos experimentos idealizados, a plataforma que sustenta estes sensores é móvel (Figs. 2.1 e 2.2). Desta maneira, os dados que são apreendidos da realidade possuem uma natureza 
complexa. Não representam uma mera sucessão de ritmos com durações pré-estabelecidas. Mas sob outro contexto, mais geográfico, representam uma intrincada espacialidade, que está vinculada aos percursos realizados pelo laboratório móvel (VOOGT e OKE, 1998b).

Tornando a relação espaço-temporal mais complexa, há também o aspecto associado ao movimento em si do veículo. Sendo que movimento aqui surge inicialmente como mero deslocar-se através de áreas da metrópole sob diferentes características climáticas. Ou seja, a velocidade praticada, mediante as possibilidades que se apresentam nas vias públicas, juntamente com uma específica resolução temporal de aquisição dos dados, implica em uma resolução espacial verdadeiramente líquida. Afinal, é constantemente mutável mediante as necessidades de aceleração e desaceleração.

Porém, isto não basta. É preciso agora se localizar. Todo esforço em vão seria se as observações não pudessem ser geograficamente posicionadas. Para isto, junta-se a todo este aparato tecnológico um GPS (Geographic Positioning System).

O GPS é fundamental, e para uma mente que apenas sob uma lógica meteorológica pensasse, ele seria provavelmente relegado a um segundo plano, ou simplesmente esquecido. Todavia, ele permite um posicionamento adequado dos dados observados. Abrindo as portas para algo que vai além de uma definição apenas fundamentada no espaço, no tempo e no movimento. A própria localização do que está sendo verificado.

Este sentido de localização insere o experimento em uma possível discussão de sua quarta conceituação, a sua geograficidade.

Evidentemente haverá as vozes que se levantarão em defesa dos modelos, subjazendo o método fundado nas observações à cozinha dos métodos de investigação. Talvez isto fosse até um elogio aos observadores, pois justamente é a observação da realidade que alimenta os modelos. Assim os modelos evoluem e também contribuem lançando novas pistas aos procedimentos dos observadores.

Está-se longe de pensar que tudo já foi observado. Este pensamento soa mesmo ridículo quando se observa o desenrolar das inúmeras possibilidades abertas por novos experimentos que são postos em prática. 
Mas por enquanto, pensando o parque humano, não apenas no seu sentido biogenético, mas estendendo-se também à própria arquitetura das criações humanas, como algo mutável, em perpétua evolução e adaptação, toda observação do fluir desta realidade faz grande sentido.

Neste aspecto, o método geográfico indica conduzir a uma perspectiva humanística fundamental. O método numérico, tão valorizado pela comunidade meteorológica nas últimas décadas, parece inconscientemente confirmar a resposta Heideggeriana aos humanistas. Nos trabalhos desenvolvidos em meteorologia (MACHADO, 1993; SILVA DIAS e MACHADO,1997), explorando-se a mesma região metropolitana, sob distintos aspectos climáticos, é espantoso como o método numérico e suas especificações em termos dos atributos do modelo abrangem a totalidade do ser meteorológico, em detrimento de toda a possibilidade de discussão da realidade humana. Como se as brisas, os fluxos e os hidrometeoros evoluíssem sobre um lugar onde o homem não mais existe.

Mesmo quando o meteorologista resolve pensar a cidade e se aproximar do homem, pensa de forma totalizadora. Mesmo quando o método fundado na observação é privilegiado, estas observações são estáticas (OLIVEIRA et al., 2002a). Muitas vezes posicionadas o suficientemente acima da UCL, justamente para que os efeitos individuais não sejam percebidos, e estes "ruídos" desvirtuem o efeito totalizador. Talvez estas observações digam mais de lugares específicos do que da cidade em si, constituída de uma abrangência tremenda de realidades específicas que não podem passar desapercebidas por aqueles que justamente habitam-na. 


\section{c) Observação, o elemento fundamental da análise}

A experiência fundada nas observações é único caminho genuíno capaz de conduzir a uma descrição realista do meio.

O que é dado ao observador pode ser coordenado em um conjunto de ferramentas e técnicas, seno gerados sistemas de apoio a decisões. Mas sem o dado de nada adiantam as ferramentas.

A partir do momento que o indivíduo reconhece-se através do meio, adquirindo consciência, as decisões estarão sempre fundadas nos dados de que ele dispõe. Isto acontece tanto em Meteorologia através do diagnóstico das características físicas da atmosfera, como em Geografia através do reconhecimento relacional entre o homem e o meio e seus desdobramentos.

Neste reconhecer e diagnosticar estão sempre presentes, de maneira imanente à temporalidade e à espacialidade, os entes que compõe as relações. Em particular à característica espacial dos entes observados, associados ao seu sentido de localização, funda-se a noção de território.

A territorialidade é uma função intrínseca a todos os sistemas fundados nos diversos ramos das ciências. Extrapolando-se as duas ciências aqui em questão, pode-se observar a importância da territorialidade nos mais diversos ramos do conhecimento. Vale aqui um exemplo distante nas ciências mercadológicas: as próprias relações de vendas e trocas podem ser entendidas em sistemas fundados em uma noção de territorialidade (KOTLER, 2000, pag.138). Com o território sendo caracterizado como um ente compacto, constituído de áreas adjacentes e equalizador das cargas de trabalho, ou no caso desta tese, dos fluxos de energia.

Esta equalização das cargas de trabalho tende a aglomerar e dispersar, centralizar e descentralizar, estruturar espacialmente tudo o que é socialmente produzido; trazendo, por fim, à existência o urbano, com sua centralidade persistente e urbanização periférica (SOJA,1993, pág. 282). A produção social é o conjunto das atividades humanas de seu aglomerado, que pode ser representada no meio pelos fluxos de massa e energia entre a região central e as regiões periféricas.

Em termos específicos dos fluxos energéticos que emanam do território urbanizado, a equalização física se dará no ar. Aquele ente do meio, que através da sua natureza física peculiar tende a propiciar a homogeneização destes fluxos. 
Nas cidades pós-modernas o zoneamento das atividades humanas tende a se restringir a áreas cada vez mais compactas (ROGERS e GUMUCHDJIAN, 2001, Capítulo II, pág. 39). A segregação territorial entre trabalho, moradia e lazer tende a ser reduzida, talvez não por um princípio de bem-estar, mas sim pelo próprio princípio de elevação da produtividade.

Prevalecendo tal modelo urbanístico, pode haver uma redução dos gradientes térmicos regionais bem identificados nos padrões de ilhas quentes e frias entre os meios densamente urbanizados e seu entorno. Estes gradientes podem vir a sofrer gradual redução, e fragmentarem-se através do território metropolitano.

Todavia, a análise deve ser cuidadosa, pois enquanto persistirem as coberturas superficiais características das superfícies do meio, os fluxos radiativos e convectivos podem continuar existindo. Com ritmos distintos talvez e durabilidade variável, mas existindo. Por isso, a observação direta destes fluxos pode ser mais reveladora do que a observação do dado aéreo, cuja natureza homogeneizadora pode esconder a essência dos fenômenos que aí se estabelecem.

Agora parece aflorar a afinidade climática que perpassa a Meteorologia e a Geografia, tomando-se por base de uma definição climática, a natureza da energética envolvida nas relações físicas dos entes no (e com o) meio.

A possibilidade de livre agir, tanto de uma como da outra ciência, é colocada em suspense. Há de se reconhecer que não se trata de simplesmente escolher entre uma via meteorológica ou uma via geográfica para se atingir o objetivo. A escolha por si só não possui fundamento, mas é o processo decisório que conduz à solução do problema. Uma decisão que faça o casamento adequado entre o ser fundamental de cada ciência.

Neste ponto, valeria ser menos Kantiano ao supor razões simplesmente materiais e exteriores à vontade e ao agir livre dos profissionais. Tornando-se mais Hegeliano em uma união entre os ramos de atividade que seja proveniente do livre e mútuo acordo entre os profissionais, que acedem, através do reconhecimento do outro, à consciência de si mesmos e a uma igualdade simbólica que suspende a desigualdade natural (GOETHE, 1810, pag. 267-269).

Excluindo-se a via oratória e a via dialética, resta a via demonstrativa para se atingir o conhecimento (ATTIE, 2002). E este conhecimento não deve ser confundido com um valor absoluto ou imutável. Este conhecimento é relativo e sempre será, pois emana das descrições 
que se faz dos dados apreendidos. E a descrição está sujeita às ferramentas e métodos disponíveis em cada época.

Nos estudos do clima de ambientes urbanos há que se perceber a identidade que fundamenta esta investigação nas metrópoles. E a identidade parece aflorar quando se percebe dois fatores: o ritmo das atividades semanais dos indivíduos que constituem o aglomerado urbano (AZEVEDO, 2001) e o processo de verticalização (SOUZA, 1994) que modula o balanço energético em uma paisagem com horizontes cada vez mais restritos. 


\section{d) Implicações atuais de concepções climáticas distintas}

As mudanças climáticas têm sido analisadas, durante as últimas décadas, através de uma grande diversidade de modelos. Mais especificamente, modelos numéricos e estocásticos. Porém, tão importante quanto o desenvolvimento destes modelos, é o levantamento de observações realizadas em campo, cuja importância vai além de um mero conjunto de informações que devem ser assimiladas inicialmente pelos modelos, e representa em si o próprio contato direto do investigador com a realidade investigada.

Neste contato com a realidade, surge de maneira inexorável a relação do homem com o meio. O clima de uma cidade, em um ambiente urbano ou rural, desponta como elemento a ser derivado dos ritmos das atividades humanas nestes ambientes, com maiores ou menores intensidades.

Não se trata mais do clima derivado apenas dos ritmos naturais, ou talvez melhor, dos elementos puramente do meio ainda sem a inserção completa do homem e suas construções e elaborações neste meio.

Deve ser neste aspecto que repousa a disputa pelo clima atmosférico, por parte da Meteorologia e da Geografia. Nos últimos anos, o que se tem observado nos Conselhos Regionais que agregam estas ciências enquanto seu aspecto profissional é uma tendência de tomada da Climatologia por parte da Meteorologia.

Estudantes e profissionais em Meteorologia reivindicam a posse pela ciência do Clima, enquanto geógrafos pouco engajados a esta realidade sucumbem a uma cada vez mais crescente desapropriação profissional.

O motivo desta configuração entre as áreas de pesquisa repousa aparentemente em dois aspectos. Por parte dos meteorologistas a questão parece estar em uma precária assimilação do homem ao meio e o entendimento adequado das relações que aí despontam. Por parte dos geógrafos, a questão parece recair no fazer profissional o que bem dele entender. Isto dispersa os geógrafos e depõe contra a própria constituição da Geografia.

Uma maneira de resolver este problema, ou aprimorar a discussão, visando um enquadramento apropriado de ambos profissionais nos conselhos que regulam as ações da profissão, seria o ir além científico chegando aos domínios filosóficos. Para isto, seria fundamental eliminar os pré-conceitos de ambas as áreas profissionais sobre a própria 
Filosofia. E o único modo para isso, talvez fosse o reconhecimento de uma filosofia realista, existencialista e conexa a um elemento ontológico de ambas as ciências.

A discussão ontológica em Geografia parece estar mais adiantada do que em Meteorologia, a partir do reconhecimento de um ser fundamental em Geografia e em Meteorologia, ou talvez mesmo da definição do ser fundamental climatológico ou climático, que provavelmente lançaria luz sobre a cisão do Clima.

Uma possibilidade pode estar nos fluxos de energia, vistos como elementos limiares das duas ciências.

Os fluxos de energia guardam de maneira coesa e singela a materialidade humana e natural. $\mathrm{O}$ dado que se apreende de um fluxo energético mantém tanto uma componente de origem natural como de origem antrópica.

Assim, provavelmente, a consciência humana reconhecerá esta idéia não através dos modelos idealizados, mas pelo reconhecimento do fenômeno sentido pela experiência humana no próprio palco em que este evolui. 
1. Onda longa e áreas urbanas 


\subsection{Camada limite urbana segundo a Escola Okeana}

A evolução climática pode resultar em diferentes perspectivas, mediante as possibilidades que se apresentam atualmente (LLOYD, 2007, pag. 224 a 227). O aquecimento global é apenas uma destas muitas possibilidades, assim como o ofuscamento global se constituiria em uma segunda e antagônica possibilidade. Ambas possíveis, ambas discrepantes e ambas permeadas por um intrincado jogo de relações físicas que se estabelece a partir da superfície para a atmosfera, e vise-versa. Ora efeito dos gases, ora efeito das partículas sólidas e líquidas que compõem este meio e interagem radiativamente modificando o balanço energético, seja propiciando a intensificação do efeito estufa, seja reduzindo a quantidade de radiação solar que diretamente atingiria e naturalmente aqueceria a superfície.

Estes processos ocorrem na camada limite (OKE, 1987, pag. 400). Um termo genérico que define a camada de ar adjacente a uma superfície.

Os climas que se estabelecem nesta camada possuem uma relação escalar fundamental com a troposfera e a estratosfera. E as trocas de energia e constituintes que se estabelecem são funções de sua estrutura vertical e de sua massa. Do mesmo modo que a troposfera corresponde a apenas $10 \%$ da dimensão vertical da estratosfera e armazena a maior parte da massa, a camada limite planetária corresponde a apenas $10 \%$ da dimensão vertical da troposfera e apresenta as concentrações em massa mais elevadas dos diversos constituintes. Sua altura em geral está associada à altura da base das nuvens e depende muito da evolução diurna e noturna.

A camada limite ainda apresenta duas sub-camadas relevantes na sua porção mais inferior, cujas alturas dependem muito da altura dos elementos rugosos que compõem os diferentes tipos de superfície: a camada de rugosidade, com altura equivalente à altura destes elementos, e a camada superficial turbulenta, com uma altura superior àquela dos elementos rugosos e definida até a cota onde ainda se verifica o efeito não uniforme da mistura turbulenta gerada a partir da superfície.

Antes de se iniciar a discussão dos processos com maior detalhamento, é importante verificar a diferença entre padrões globais e padrões locais (LLOYD, 2007, pag. 31, 34, 46, 68 e 91 a 96). 
Os padrões globais podem estar, por exemplo, associados à dimensão total da atmosfera (desde a troposfera até a ionosfera), como também à dimensão espacial ou temporal de um evento isolado, considerando-se, sobretudo, sua natural repetição através da superfície planetária.

Enquanto os padrões locais podem estar, por exemplo, associados a uma pluma de CO que escoa sobre um continente, ao desenvolvimento de um cumulonimbus, à névoa sobre uma cidade ou à própria conformação térmica desta cidade, estes eventos não possuem necessariamente abrangência planetária. Apesar de distribuídos através de continentes ou oceanos, esta distribuição é irregular e relativamente incerta.

Algumas ferramentas conceituais são úteis para o reconhecimento dos padrões escalares a serem estudados ou identificados na camada limite (STULL, 1988), afinal estes padrões são simultâneos e se inter-relacionam através dos domínios próprios de cada um. Um exemplo é o registro da evolução da velocidade do vento. Em um período de duas horas, certamente é possível verificar diferentes comprimentos e amplitudes de onda, associados ao vento sinóptico de escala mais abrangente, desde os grandes turbilhões associados às brisas ou à convecção, até as pequenas ondas associadas à mistura turbulenta irregular próxima à superfície.

Em situações nas quais a escala local predomina sobre a escala sinóptica, especialmente em dias e noites de céu claro e com vento calmo, a estrutura da camada limite pode ser totalmente reconhecida (STULL, 1988, pag. 11). A profundidade da camada limite varia e evolui conforme o dia e a noite transcorrem, em harmonia com o ciclo de aquecimento e resfriamento superficiais. A camada de mistura convectiva que se desenvolve no seu interior durante o dia dá lugar, à noite, a uma camada estável cerca de dez vezes menor. Todavia, mesmo com o desenvolvimento desta camada estável próxima à superfície, ainda se pode observar a existência de uma camada de mistura residual, situada mais acima e, portanto, já desconectada da superfície.

Possíveis modificações inadvertidas do clima podem ser preconizadas a partir da edificação de uma cidade e da reunião de todos os seus elementos que lhe são característicos (OKE,1987,pag. 274). Uma pluma urbana, advectada por ventos de uma escala regional maior, pode ser imaginada difundindo as características das áreas urbanas e suburbanas para as áreas rurais. Esta pluma possuiria um vínculo superficial com a camada situada abaixo das coberturas urbanas (Urban Canopy Layer - UCL) e através do transporte vertical sobre a 
cidade teria estas características transportadas para níveis mais elevados da camada limite urbana. Posteriormente, pela advecção regional, estas características atingiriam os níveis acima da própria camada limite rural que se desenvolve ao redor. Até onde poderiam persistir os efeitos desta pluma, é ainda elemento de discussão.

A mistura que ocorre no interior da camada limite é devido em diferentes graus de magnitude a dois elementos fundamentais, à fricção dos ventos, dos veículos e dos indivíduos que se deslocam sobre a cidade, e à convecção (GEIGER et al., 2003, pag. 37). Uma visualização do processo convectivo é possível a partir de alguns experimentos idealizados. Em todos os casos verifica-se sua estrutura espacial altamente irregular, de complexa determinação e tratamento iminentemente estocástico. É possível reconhecer setores com movimentos ascendentes, onde o ar mais aquecido eleva-se a partir da superfície, e setores com movimentos subsidentes, onde o ar mais frio das camadas superiores é transportado pela mistura aos níveis próximos ao piso superficial.

Sobre uma superfície com ocupação irregular desenvolvem-se inúmeros microclimas com suas características peculiares. Conforme a mistura vertical desenvolve-se, estes microclimas tendem a uma gradual homogeneização nos níveis mais elevados (GEIGER et al., 2003, pag.3). De tal modo que uma área cada vez mais abrangente pode ser climaticamente reconhecida para um nível cada vez mais alto. Ou seja, de maneira consecutiva, a partir de uma reunião de microclimas (primeiras dezenas de metros acima da superfície) ter-se-á a definição de um topoclima (em torno de $100 \mathrm{~m}$ acima). Por sua vez, alguns topoclimas espacialmente distribuídos definem um mesoclima específico (entre $1 \mathrm{~km}$ e $2 \mathrm{~km}$ acima). Até, enfim, ter-se a definição de um macroclima em torno de $4 \mathrm{~km}$ reunindo alguns mesoclimas prédefinidos. Esta idéia é uma tentativa para a compreensão e ordenamento da estrutura escalar do clima e provém da teoria dos conjuntos.

Deste modo, é agora possível reconhecer cenas dos climas em relação à sua relação escalar(LLOYD, 2007, pag. 15 a 28 e 90 a 93). Por exemplo, o macroclima de um planeta, o mesoclima de uma região costeira, o topoclima de uma cidade ou o microclima de uma floresta.

Uma modificação qualquer sobre o clima, causada por áreas urbanas está essencialmente associada ao estabelecimento de um novo equilíbrio entre os termos do balanço de energia $\left(Q^{*}\right.$ - saldo entre os fluxos radiativos; $Q_{F}$ - fluxo de energia antropogênica; $Q_{H}$ - calor sensível turbulento; $\mathrm{Q}_{\mathrm{E}}$ - calor latente turbulento; $\Delta \mathrm{Q}_{\mathrm{S}}$ - variação da energia armazenada; $\Delta \mathrm{Q}_{\mathrm{A}}$ 
- variação do fluxo de energia advectada; $\mathrm{S}$ - demais fluxos de energia associados a outros fatores tais como fotossíntese, precipitação e escoamentos superficiais) e os termos do balanço hídrico ( $\mathrm{p}$ - precipitação; F - água liberada pela combustão; I - suprimento de água a partir de rios e reservatórios; $\mathrm{E}$ - evaporação; $\Delta \mathrm{r}$ - variação do escoamento superficial; $\Delta \mathrm{S}$ variação da água armazenada; $\Delta \mathrm{A}$ - variação da umidade advectada), inerentes ao meio urbano, que fluem através da camada abaixo das coberturas e desta para os níveis mais profundos da camada limite (OKE, 1987, pag. 275). Estes termos são reunidos através das seguintes expressões, onde os termos à esquerda da igualdade correspondem aos termos fontes, enquanto os termos à direita da igualdade correspondem aos termos sumidouros:

$$
\begin{aligned}
& \mathrm{Q}^{*}+\mathrm{Q}_{\mathrm{F}}=\mathrm{Q}_{\mathrm{H}}+\mathrm{Q}_{\mathrm{E}}+\Delta \mathrm{Q}_{\mathrm{S}}+\Delta \mathrm{Q}_{\mathrm{A}}+\mathrm{S} \\
& \mathrm{p}+\mathrm{F}+\mathrm{I}=\mathrm{E}+\Delta \mathrm{r}+\Delta \mathrm{S}+\Delta \mathrm{A}
\end{aligned}
$$

Desde as décadas mais recentes, alguns destes termos já podem ser avaliados diretamente no âmbito da camada limite através de sensores cuja resposta é o próprio fluxo de energia (OKE,1987; LINACRE, 1992). O fluxo Q*, por exemplo, pode ser avaliado com o uso de saldo-radiômetros, ou mesmo de componentes mais específicas deste fluxo, como a radiação difusa em ondas curtas, utilizando-se radiômetros acoplados a anéis de sombreamento. Em geral, os fluxos radiativos passam a ser determinados diretamente no momento em que são empregados radiômetros, cujo princípio de funcionamento básico é definido pela utilização de sensores bimetálicos ou termopilhas. Além destes fluxos, os fluxos turbulentos também passaram a ser avaliados diretamente, utilizando-se anemômetros sônicos e higrômetros de Kripton. Todavia, estes últimos representam sensores de mais complexa manipulação, principalmente pelas maiores dificuldades encontradas no posicionamento adequado dos sensores e das correções envolvidas nos sinais obtidos por intermédio destes.

Mas nem sempre há condições para se efetuar diretamente a avaliação dos fluxos. Por este motivo, continuam sendo importantes as observações de dados climáticos mais convencionais, que devidamente parametrizados podem fornecer estimativas dos fluxos e constituírem-se em extensões dos próprios recursos sensoriais humanos. Por exemplo, a temperatura e a umidade relativa do ar com a utilização de psicrômetros; a precipitação, utilizando-se pluviômetros eletrônicos mais precisos, do tipo tipping bucket; os ventos, inclusive os de intensidade baixa, porém tão relevantes nas transferências de energia, com uso de anemômetros Gill (Young Ins.) de simples determinação da direção e conseqüentemente das três componentes geométricas (inclusive a vertical), bem como da intensidade, 
empregando-se hélices de pouquíssima inércia, fabricadas com isopor; ou mesmo o conteúdo de umidade do solo que pode ser avaliado com a utilização de lisímetros, as temperaturas superficiais com uso de termistores ou termopares e até o transporte de água através das plantas empregando-se manômetros.

Previsões modernas das condições de tempo que contribuem influenciando o clima, utilizamse destes sensores, ora dispostos em uma rede de estações fixas, ora sob determinadas condições, em bases móveis, geo-referenciadas e de coleta automática (LLOYD, 2007, pag. 170 a 184). Além disso, consideram também dados remotos obtidos por bases orbitais (satélites) ou terrestres (radares), ou, inclusive, estimativas de campos através de métodos físicos, escalares ou numéricos.

Há ainda estimativas que podem ser realizadas com respeito aos climas pretéritos de uma localidade (LLOYD, 2007, pag. 201 a 208). Nesta circunstância, de nada valem os sensores e equipamentos mencionados anteriormente. Deve-se, neste caso, utilizar uma outra fonte de dados, os proxy data. Um proxy data não é efetivamente um dado, mas sim um elemento que traz consigo uma "procuração" de um dado que na realidade não existe mais, e sua reconstituição integral é simplesmente impossível. Estes chamados proxy data possuem imprecisões inerentes que vão além das imprecisões associadas a um sensor presente, todavia podem funcionar como estimativas remotas, não em termos do distanciamento espacial, e sim em termos da evolução temporal. São exemplos de proxy data os perfis verticais de sedimentos com respeito a eras geológicas muito longevas, o conhecimento do deslocamento tectônico como a deriva continental com respeito a eras geológicas intermédias, os perfis verticais glaciais com respeito às eras mais recentes, ou mesmo a dendroclimatologia que a despeito da própria evolução vegetal mantém nos anéis cauliares uma informação parcialmente pertinente aos últimos períodos incluindo-se associações com registros históricos.

Deste modo já é possível iniciar o reconhecimento do clima em sua essência, e, evidentemente, da sua variação, seja espacial, ou seja (como é muito evidenciado hoje em dia) temporal (BRADLEY, 1999, pag. 12). Observe-se que não há nada de espetacular neste ponto, afinal o ato de variar ou o estar sujeito à mudança é uma característica inexorável de todo e qualquer ente físico observado na natureza. E o que se observa é sempre uma variação rítmica, ou seja, definida por uma duração (período) e atrelada evidentemente ao regresso de um evento específico. O interesse surge com respeito ao modo (variabilidade - "infeliz anglicanismo") com que ocorre a variação, ou a oscilação. Esta oscilação pode ocorrer de 
diversas maneiras e associar-se às mais diversas razões. Por exemplo, de uma maneira bastante abrangente pode ser uma onda "suave" de período muito longo, pode ser uma onda mais curta intermeada por ondas muito menores (alguns as tratam inadvertidamente como ruídos) incluindo-se até mesmo alterações bruscas de patamares (associadas a mudanças impulsivas de tendência central e esporádica), pode ser uma onda muito curta associada a alterações suaves entre patamares (associadas a ondas muito mais longas), ou pode ser simplesmente uma onda de tendência central que se amplifica ou atenua-se (como o ciclo de "vida" de um cumulonimbus).

Portanto, define-se os estudos climatológicos físicos globais como o reconhecimento destes ciclos, que mesmo podendo remontar a eras longevas é sempre fruto de uma estimativa local, e sua abrangência espacial só será de fato reconhecida mediante a repetitividade "em fase" dos eventos pelo globo (HARTMANN, 1994; BRADLEY, 1999). A resolução temporal destas estimativas cíclicas também varia temporalmente (como uma segunda derivação), e é sempre maior para os períodos mais recentes da era Cenozóica do que para as eras Mesozóica e Paleozóica (como um telescópio observando o infinito). Apenas para as últimas centenas de milhares de anos (baixo Pleistoceno) os ciclos, com suas durações, passam a ser mais claramente identificados. Mas quando se aproxima para os últimos séculos apenas, ocorre o inverso, uma perda em perspectiva (a visão torna-se míope), e os ciclos de curtíssimo período observados ganham proporções avassaladoras. É por isso prudente, e sobretudo coerente, buscar sempre a conexão entre ciclos de períodos curtos e longos, afinal são todos simultâneos, e o tratamento individualizado sempre requer assim um conhecimento profundo sobre o seu significado.

A partir deste ponto pode-se definir com clareza os padrões globais e locais (Orbi et Urbi) para o mundo em que vivemos (LLOYD, 2007, pag. 25 a 93): desde a escala global, definitivamente vinculada à estrela solar e ao meio sideral pelo qual o planeta Terra e os demais estão imersos, até a escala local da cidade, do lugar onde o homem efetivamente vive e busca distanciar-se das ações do global, criando um detalhamento de relações complexas com seu meio cujo reconhecimento é o objetivo principal aqui.

Dentre estas inúmeras relações, algumas que mais interessam ao homem são as definidas pela transferência radiativa (WALLACE and HOBBS, 2006), por ser esta transferência o processo mais eficiente pelo qual a energia flui entre o homem e o meio, bem como através deste, e ser simultaneamente influenciada por todo e qualquer constituinte atmosférico, natural (moléculas, gases, poeira, gotas e cristais) ou antrópico (gases e poeira). Dando-se 
preliminarmente e universalmente em dois sentidos segundo um modelo vertical da atmosfera, de cima para baixo, preferencialmente como ondas curtas (radiação visível de origem solar) e resultante da ação do global sobre o local, e de baixo para cima, preferencialmente como ondas longas (radiação infravermelha termal originária de todos os corpos que compõem a superfície) e resultante da ação do local sobre o global.

Esta relação entre as componentes (onda curta e onda longa) do fluxo radiativo implica na principal fonte natural para o balanço de energia, que por sua vez constitui-se no fundamento básico de todos os modelos climáticos idealizados (LIOU, 2002, pag. 490). Em termos globais observa-se um fluxo resultante para baixo em ondas curtas com forte dependência meridional e máximo no setor equatorial definido pelo posicionamento astronômico, um fluxo resultante para cima em ondas longas com fraca dependência meridional e dois máximos nos setores subtropicais definidos pela pouca nebulosidade, e um fluxo resultante turbulento (sumidouro de energia) para cima também com forte dependência meridional e um patamar máximo no setor tropical, porém definido pelo grau de aquecimento superficial. A dissipação de energia a partir da superfície para a atmosfera, no setor tropical do planeta, é cerca de $100 \%$ mais intensa através dos processos turbulentos do que através da perda radiativa em ondas longas. No setor em torno das latitudes médias esta proporção cai para apenas 10\%. Enquanto nos setores polares, especialmente sobre o Ártico, esta proporção chega a inverter-se com os fluxos turbulentos tornando-se ínfimos em comparação à perda em ondas longas.

A base física para o entendimento das trocas turbulentas na camada limite entre a superfície e a atmosfera, de uma maneira geral para todas as escalas, reside na compreensão da sucessão entre os ritmos diurnos e noturnos (OKE, 1987, pag. 42). Durante o dia a turbulência na camada superficial intensifica-se propiciando o surgimento acima de uma extensa camada de mistura formada por grandes turbilhões que se prolongam até a base da inversão térmica em altitude, aproximadamente a base das nuvens (ou até próximo ao nível de condensação por levantamento). Esta camada de mistura é caracterizada pela ausência de variação vertical da temperatura potencial ( $\theta$ - uma categoria de temperatura que independe da variação de pressão, veja OKE, 1987, pag. 53 e 54), e pela existência de um gradiente vertical negativo do fluxo $\mathrm{Q}_{\mathrm{H}}$, o qual condiciona o transporte convectivo de energia da superfície para a atmosfera. Durante a noite a turbulência na camada superficial dissipa-se, bem como a mistura acima desorganiza-se, propiciando o aprofundamento da inversão térmica em altitude até muito próximo à superfície. Surge uma camada de inversão que é caracterizada por um gradiente vertical positivo de $\theta$ e pelo intenso enfraquecimento do gradiente vertical do fluxo $\mathrm{Q}_{\mathrm{H}}$, a 
ponto até de ocorrer sua inversão tornando-se ligeiramente positivo e transportando energia da atmosfera para a superfície.

Os processos convectivos podem mesmo ir além da camada de mistura, estendendo-se para as camadas mais elevadas da atmosfera e originando as tempestades convectivas (HOLTON,2004, fig 9.12).

Esta convecção profunda juntamente com os efeitos topográficos sobre a circulação atmosférica representam um elo importante entre a turbulência superficial e o surgimento de ondas atmosféricas (NAPPO, 2002, pag. 135). Estas ondas podem persistir por longas distâncias (desde o ponto de instabilidade até se dissiparem), como ondas de gravidade de diferentes amplitudes dependentes fundamentalmente do grau de estabilidade da atmosfera nas diferentes localidades atravessadas por elas.

A partir do momento no qual se concebe de modo claro a distinção entre escalas e a relação entre fenômenos de suas diversas magnitudes, torna-se possível, conceber o modelo de relações entre a cidade e a sua atmosfera, constituindo-se assim o clima urbano. Antes, no entanto, é preciso deixar claro que modelos não são jamais definitivos. O que se apresenta aqui é uma concepção cientificamente elaborada por diversos pesquisadores durante as últimas décadas, por ser considerado ser um modo coerente e satisfatório para explicar o clima urbano. Todavia, deve-se observar que os modelos sempre foram elaborados desde muitos séculos. É antes uma necessidade humana modelar para compreender e para sobreviver, muito anterior que a própria Ciência. Vale lembrar que modelos do Universo já eram feitos por todas sociedades ancestrais, destacando-se os mais elaborados a partir da Idade do Bronze, em termos das relações climáticas alguns dos mais notáveis talvez sejam os pertencentes às culturas pré-colombianas. É digna de menção a representação de Quetzalcoatl pelos aztecas, e anteriormente em uma forma diversa pelas comunidades maias (LLOYD, 2007, pag. 157). Quetzalcoatl não era tão somente o criador da vida, mas curiosamente, e talvez não por acaso, era também a divindade dos ventos que sopravam as chuvas - um interessante mito atribuído de "poderes advectivos". A sua própria representação pode causar fascínio ao verificar quão singelamente está lá amalgamada a relação entre a superfície e o meio aéreo, a partir da união inexorável do representante animal do reino terreno (Coatl, a serpente), ao qual estava o homem inevitavelmente atrelado, com o representante do reino aéreo (Quetzal, a ave), ao qual dirigiam-se todos os medos e todas as esperanças por uma fonte de energia e de água que fossem devidamente equilibradas e balanceadas para o sustento da vida sobre a terra. 
Evidentemente, deixando apenas aos sonhos e devaneios o poder destes mitos ancestrais e de outros que se imponham pelas sociedades modernas, nos concentremos na representação científica do clima urbano. Bem, uma das primeiras preocupações é "colocar ordem na casa", trazer à tona um modo de comunicação em clima urbano que possa favorecer a compreensão mútua entre pesquisadores, cientistas e investigadores, que não tenham necessariamente a mesma base acadêmica, e, ao mesmo tempo, não reter a essência dos processos mais significativos (OKE, 2006). O princípio fundamental está em reconhecer que o clima urbano está vinculado a dois aspectos distintos e igualmente relevantes, a topografia e a ocupação do solo. Dependendo do relevo onde a cidade está inserida, ou do relevo no interior da própria cidade, os fenômenos climáticos serão afetados distintamente, do mesmo modo que a diversidade de ocupações dentro dela também o afetará. Dentre as ocupações destaca-se as dimensões geométricas das edificações, o modo de impermeabilização do solo quando houver, bem como a presença da própria vegetação, gerando-se a partir destes tipologias específicas.

Levando em conta a análise a partir da geometria das edificações e dos canyons consequientemente criados, deve-se mencionar um dos primeiros efeitos significativos gerados, o efeito da ilha urbana de calor (OKE, 1981), a ilha atmosférica diga-se de passagem. Aquém dos materiais e da própria constituição atmosférica, o efeito de ilha de calor é um efeito que muitas vezes está associado ao grau de visibilidade da abóbada celeste. Esta observação traz em evidência o fato de que antes de mais nada este efeito está relacionado à intensidade da perda radiativa em ondas longas. Isto porque a "temperatura do céu" é em geral inferior àquela associada às paredes dos edifícios ou à vegetação.

Por outro lado, as conclusões possíveis de se chegar a respeito do clima urbano também podem ser diversas mediante o posicionamento do observador e a definição do que é a própria superfície (VOOGT and OKE, 1997; 1998a). Especialmente para o caso de bases de observação orbitais deve-se perceber que dificilmente se conseguirá uma representação completa da superfície urbana com todas as suas formas. Para sensores posicionados na direção do nadir, por exemplo, não haverá consideração alguma a respeito das paredes dos edifícios ou sobre "aquilo" que esteja abaixo da vegetação. Sensores posicionados "fora" da direção do nadir resolvem em parte o problema, todavia sempre restarão parcelas "sombreadas" pelo alvo. Note-se que ao incluir o sol a este sistema há ainda a consideração que deve ser feita a respeito do próprio sombreamento dos alvos em relação à incidência dos raios solares. 
A definição do que se compreende como superfície também constitui um problema em si. Muitas superfícies podem ser definidas, o investigador deve sempre deixar claro à qual se refere. Há, por exemplo, a superfície completa que considera simplesmente tudo, as paredes, as coberturas, os pisos dentro e fora das edificações, a vegetação e próprio ar dentro e fora das edificações. Ou a superfície do nível do chão que considera apenas os pisos, seja fora como também dentro das edificações. Ou ainda a superfície dos topos das coberturas que considera uma secção média que atravessa (ou acompanha) o nível médio (ou exato) onde se encontram os topos das edificações, e que neste caso tudo abaixo seria tratado como uma "caixa preta" (desconhecido). Ou, então, quem sabe, a superfície vista pelos olhos de um pássaro na qual estariam incluídos os topos das edificações e da vegetação, bem como o piso externo às edificações e não encoberto pela vegetação. Ou talvez, finalmente, uma superfície deslocada do plano zero constituída nada mais do que por uma secção paralela e superior ao piso, em determinada cota, atravessando edificações e vegetação e abrangendo ao mesmo tempo o ar interno e externo às edificações. Entretanto, em todos estes casos, o pesquisador que estuda o clima urbano deveria, em geral, definir a superfície como uma secção paralela ao piso, ou que acompanhasse sua topografia através de edificações e vegetação, abrangendo o ar externo às edificações e, principalmente, que se posicionasse a uma exata cota acima do piso e fosse coincidente com a altura média dos indivíduos que habitam a cidade. Este nível poderia ser considerado o nível das sensações humanas, cujas características físicas impingiriam influência imediata sobre a derme dos indivíduos (AZEVEDO, 2001).

Em termos das relações entre elementos que compõem as superfícies urbanas merece destaque a relação entre ruas e parques (SPRONKEN-SMITH and OKE, 1999), seja em termos das trocas de energia entre a vegetação, as paredes das edificações e o meio atmosférico (OKE, 1989), seja em termos das circulações induzidas nos canyons urbanos (NAKAMURA and OKE, 1988). A vegetação funciona no meio urbano como um regulador energético, ao mesmo tempo acumulando energia através do armazenamento do saldo entre os fluxos do balanço de energia e também da fotossíntese, ou dissipando-a através da transpiração e também da respiração, enquanto os canyons participam distribuindo entre as paredes e os pisos a energia acumulada pelo aquecimento diferencial, isso através das circulações transversais de ritmo diário que surgem devido a este aquecimento e funcionam como células fechadas de brisa intra-canyon com uma componente ascendente nas paredes mais aquecidas e outra descendente sobre as paredes mais frias.

A disposição relativa entre edificações e vegetação, bem como a distribuição espacial destes elementos na cidade, contribuem para a ocorrência de padrões específicos de evaporação 
urbana e ocorrência de orvalho, que são processos importantes para definir a distribuição de umidade em uma cidade (GRIMMOND and OKE, 1991; RICHARDS and OKE, 2002). Esta distribuição está associada entre outros fatores à temperatura superficial e ao fator de visão do céu. Áreas mais abertas, com menor obstrução da abóbada celeste, geralmente tendem a apresentar temperaturas da superfície inferiores em comparação com áreas encobertas. Por conseguinte, superfícies mais frias são favoráveis à deposição de orvalho. Em contrapartida, áreas arborizadas, por exemplo, tendem a retardar o resfriamento superficial e, portanto, a desfavorecer a ocorrência de orvalho, ou até mesmo geadas, sobre a superfície inferior.

Todas as características físicas inerentes ao meio urbano, cujos padrões evoluem abaixo da camada de coberturas, podem ser transferidas para camadas atmosféricas acima destas coberturas através dos movimentos e fluxos turbulentos (ROTH and OKE, 1995; GRIMMOND and OKE, 1999). A turbulência por sua vez, acima das coberturas, já no interior da camada de mistura, é representada por grandes turbilhões que tendem a continuar o processo de homogeneização iniciado mais abaixo. Surgem grandes células sobre a cidade que favorecem a ocorrência de descontinuidades nas distribuições espaciais de variáveis, como componente vertical do vento, temperatura e umidade. Ou podem, ainda, favorecer a ocorrência de máximos isolados associados aos fluxos verticais de temperatura e umidade. Em ambos os casos a variabilidade está associada aos ramos ascendentes e descendentes destas células relacionadas aos grandes turbilhões. A altura da camada de mistura e, portanto a própria turbulência acima da cidade, terá magnitude distinta em decorrência da rugosidade urbana. Em uma escala superior àquela do canyon urbano, a cidade pode ser representada como um grande elemento rugoso em superfície, e as edificações seus pequenos constituintes. Conforme a distância entre as edificações (largura do canyon) for maior ou menor, a rugosidade acima da cidade será também variável, favorecendo ou desfavorecendo a evolução dos grandes turbilhões da camada de mistura até mais acima onde evolui a circulação de mesoescala. Mas note que existe um certo distanciamento entre as edificações no qual a rugosidade é máxima. Ela tende a decair tanto para o caso em que as edificações são muito afastadas, quanto para o caso em que elas estão muito próximas, praticamente formando um único corpo.

No entanto, estes fluxos turbulentos que emanam da cidade, ou de seus elementos, possuem uma distribuição espacial muito variada. Um modo para tratar a complexidade deste fenômeno é a inserção do conceito de áreas fonte (SCHMID et al., 1991). Segundo este conceito, cada elemento contribui com um fluxo turbulento característico, cuja área de abrangência será uma forma plana aproximadamente elipsóide de excentricidade dependente 
da intensidade do vento da escala superior e da rugosidade superficial do local. Ou seja, um observador fixo na superfície receberá a influência de determinados fluxos turbulentos, que não necessariamente são uma média dos fluxos ao seu redor, mas sim a contribuição de algum setor específico, dependente basicamente da direção do vento na escala superior.

Os fluxos do balanço de energia na cidade podem também ser estimados numericamente por intermédio de relações determinísticas ou mesmo estocásticas sob condições idealizadas. Neste caso é fundamental que tais estimativas não sejam consideradas sem antes ser realizada a devida validação mediante os fluxos observados ou estimados em campo sob condições reais (MASSON et al., 2002). Métodos numéricos costumam fornecer boas estimativas do fluxo $Q^{*}$ acima da camada de coberturas. Mas no interior desta camada a complexidade aumenta e as validações deixam de ser satisfatórias. Podem ocorrer também superestimativas mesmo acima das coberturas para o fluxo $\mathrm{Q}_{\mathrm{H}}$, por exemplo. No caso do fluxo $\Delta \mathrm{Q}_{\mathrm{S}}$, no entanto, ocorre o inverso, com subestimativa por parte do método numérico. Estas discrepâncias notadas entre o idealizado e o observado devem-se, em grande medida, à incapacidade do método numérico abranger toda a especificidade de variedades entre os elementos emanantes de fluxos turbulentos ou mesmo radiativos abaixo das coberturas.

As observações meteorológicas em uma cidade, quando considerados os perfis verticais, propiciam a identificação das diferentes subcamadas associadas à camada limite (OKE, 2004). Acima está a camada de mistura e abaixo a camada superficial. A camada superficial ainda se subdivide: acima a camada inercial, onde o fluxo turbulento torna-se praticamente constante, e abaixo a subcamada de rugosidade, onde ainda há grande variabilidade do fluxo turbulento. Porém, a subcamada de rugosidade ainda é mais elevada que a própria camada de coberturas, pois a intensa mistura turbulenta que emana do interior dos canyons ainda tende a se propagar alguns metros, ou dezenas de metros, acima das coberturas. Esta complexa estrutura de camadas flui, na realidade, como uma pluma acima da cidade, advectada pelo vento de escalas superiores (da mesoescala à escala sinóptica). Todavia, há uma estrutura que permanece bastante característica da presença da cidade, o perfil logarítmico vertical da intensidade do vento horizontal. $\mathrm{O}$ vento tende a aumentar logaritmicamente acima da cidade até equipararse ao vento da escala superior. No entanto, nota-se que abaixo, no interior dos canyons, também há um perfil logarítmico de intensidade inferior. Os dois perfis apresentam um intervalo de continuidade definido por um ponto de inflexão, cuja cota pode corresponder ou a uma distância das coberturas $\left(\mathrm{z}_{0}\right)$ ou a uma distância do piso $\left(\mathrm{z}_{\mathrm{d}}\right)$. 
De um modo geral, o balanço de energia na superfície urbana pode ser resumido como um complexo de relações onde se destaca a reunião de: características radiativas dos materiais (albedo e emissividade); diferentes capacidades em gerar fluxos turbulentos de calor sensível a partir da diversidade de elementos abaixo das coberturas, propagando-se acima até uma homogeneização aparente através de uma tipificação de camadas e subcamadas (OKE,1988; OKE et al., 1989); e irregularidade dos fluxos turbulentos de calor latente sob a presença de parques que contribuem para o surgimento de efeitos característicos, como o de "oásis" ou do tipo "borda" (SPRONKEN-SMITH et al., 2000), onde intensidades pronunciadas dos fluxos podem estar associadas a processos advectivos através de distintos tipos de ocupação do solo.

Os fluxos podem ainda ser parametrizados, mesmo que não observados diretamente ou estimados por métodos numéricos sofisticados, ser parametrizados (GRIMMOND and OKE, 2002), ou seja, podem ser estimados através de relações com outros parâmetros mais facilmente observáveis. Esta área de estudo na Climatologia Urbana constitui-se em uma interface muito interessante a ser mais explorada entre a Ciência Meteorológica e a Ciência Geográfica. Fluxos como $\mathrm{Q}^{*}, \mathrm{Q}_{\mathrm{H}}, \mathrm{Q}_{\mathrm{E}}, \Delta \mathrm{Q}_{\mathrm{S}}, \mathrm{K} \downarrow, \mathrm{L} \downarrow$, ou mesmo parâmetros como o comprimento de Monin-Obukhov (L) e a velocidade de fricção (u*), podem ser parametrizados, por um lado, a partir de observações meteorológicas convencionais da temperatura do ar, da umidade absoluta, da pressão atmosférica e da velocidade e direção do vento, e, por outro lado, a partir de sistemas geográficos de informações sobre morfometria e cobertura superficial.

Portanto, fica agora mais claro o longo percurso e as principais variações envolvidas nas singelas expressões representadas para os balanços energético e hídrico (Eqs. I e II) em uma cidade. Desse modo, tem-se uma representação sucinta para as relações de balanço de energia e de balanço hídrico de um volume de edificações preenchidas por ar, seja para uma edificação isolada, seja para o conjunto de elementos urbanos, seja para a microescala, seja para a topoescala (OKE, 1987; OFFERLE et al., 2006).

Em termos do balanço de energia, é ainda importante observar o detalhe da orientação dos fluxos verticais. É muito comum comparar-se representações gráficas dos termos do balanço e notar-se uma certa discrepância de sentido entre curvas, especialmente entre os ciclos diurno e noturno. Algumas vezes o ciclo evolutivo de um determinado termo do balanço é positivo, em outros casos, sob as mesmas condições, o mesmo ciclo é negativo. Esta controvérsia é fruto de um tratamento distinto, deste mesmo assunto, dado por duas escolas distintas. A escola meteorológica, adepta da representação Stullniana (STULL,1988), representa os termos do 
balanço conforme o sentido de propagação do fluxo. Ou seja, o ciclo é positivo se o fluxo é dirigido para cima a partir da superfície, ou o ciclo é negativo se o fluxo é dirigido para baixo a partir do topo da atmosfera. Para a escola geográfica, adepta da representação Okeana (OKE, 1987), os termos do balanço são representados mediante a conformidade da natureza do fluxo. Ou seja, a priori todos os ciclos são positivos, desde que sua natureza esteja em conformidade com a relação algébrica expressa. Melhor dizendo, se os termos à esquerda da igualdade (Eq.I) representam efetivamente uma fonte de energia para a superfície, e se os termos à direita representam efetivamente um sumidouro de energia, todos os ciclos serão positivos. No entanto, caso algum destes termos torne-se de fonte um sumidouro, ou, por outro lado, de sumidouro uma fonte, esta inversão no significado físico a priori resultará em uma representação gráfica negativa do ciclo diário ou noturno do fluxo de energia em questão.

Todos os corpos e o meio em que eles se encontram trocam quantidades de energia entre si, dentre outras formas (condução e convecção), também por radiação em ondas longas. No contexto deste trabalho as ondas longas não são entendidas no seu sentido mais abrangente, porém, restritamente associadas à faixa espectral que compreende o infravermelho termal.

Ao se mencionar trocas de energia pressupõe-se uma fonte de energia. Devido à complexidade envolvida em torno da estimativa das fontes antropogênicas de calor (AZEVEDO, 2001), vamos considerar a priori apenas uma fonte natural, ou seja, a radiação solar, sobretudo a sua componente visível:

"Parte da radiação solar é convertida em radiação infravermelha, ao atravessar a atmosfera. Na superfície, uma parcela da radiação visível também é convertida em infravermelha. Parte da radiação refletida é interceptada pela atmosfera e re-emitida em ondas longas. O Planeta opera como um conversor de radiação, que alonga o comprimento das ondas, de uma parcela significativa da radiação visível para infravermelha" (AZEVEDO,2001).

Sob condições de vento calmo e céu claro, com pequenas taxas de transferência turbulenta superficial de calor sensível e latente, o resfriamento noturno em parques e na superfície urbana de uma maneira geral é determinado pela capacidade dos materiais sub-superficiais em armazenar calor, e também pelo saldo do fluxo radiativo em ondas longas (SPRONKENSMITH e OKE, 1999). A geometria da superfície age como uma "prisão" da radiação de onda longa (VOOGT e OKE, 1998 a), contribuindo para o aumento da emissividade efetiva de 
superfícies rugosas (SUTHERLAND e BARTHOLIC, 1977; ARNFIELD, 1982; CASELLES et al., 1988).

A ocorrência dispersa de áreas verdes, em meio a uma região edificada, tende a fragmentar a estrutura tipicamente idealizada do que vem a ser o meio urbano. Este aspecto aumenta a complexidade escalar, em especial no que diz respeito à análise dos topoclimas e microclimas que se estabelecem nesse meio.

Um caso notável repousa na dificuldade em determinar a espacialização e a temporalidade das temperaturas mínimas em setores que funcionam como interface entre áreas verdes e áreas edificadas. Deve-se citar o estudo de Ribeiro e Azevedo (2005), onde analisam o comportamento climático entre a área do Campus da Universidade de São Paulo, composto por significativa cobertura vegetal, e o seu entorno, densamente edificado e pavimentado. Segundo esse estudo, a localização da menor temperatura fica bem caracterizada, em diversos horários do dia, com cerca de $40 \%$ dos casos, porém, em posições distintas. Sendo que se verifica sua ocorrência no interior da mata do Campus universitário no início da manhã e ao final do período vespertino. Por outro lado, durante a noite, os pesquisadores verificam que a temperatura mínima ocorre preferencialmente na fronteira, entre o Campus e o entorno. Curiosamente, não se verifica praticamente o registro de temperaturas mínimas sobre os gramados do Campus, ao passo que Azevedo (2002 a) observa a formação de orvalho, neste período, sobre os gramados, que estão posicionados preferencialmente sobre vertentes. Este evento é explicado (RIBEIRO e AZEVEDO, 2005) pelo escoamento do ar frio noturno, a uma altura inferior a um metro - sendo que os sensores climatológicos são em geral instalados acima deste nível, para o fundo de uma cabeceira de drenagem onde se localiza a área de fronteira entre as ocupações distintas. Dessa maneira, as diferenças térmicas, entre setores heterogêneos de uma área, tendem a ser amenizadas, com os gramados funcionando como escoadouros do fluxo radiativo termal e induzindo uma segunda componente deste fluxo, do entorno para o interior do Campus.

Devido à complexidade inerente a sua determinação (SALVI-SAKAMOTO, 2001), as observações diretas da temperatura do ar poderiam ser substituídas por observações do balanço do fluxo de ondas longas, o qual está relacionado com as temperaturas das diversas superfícies.

Estes exemplos ilustram de maneira crível a complexidade da busca de uma significância espacial para os padrões estimados dos fluxos radiativos em ondas longas. Sobretudo, quando 
conectados simultaneamente ao contexto de análise: o caráter topográfico, o caráter ocupacional dos diversos territórios na área em questão e a heterogeneidade de usos inerentes às atividades socioeconômicas em uma área definida, por princípios teóricos, como urbana. Em especial, se abordada paralelamente a outros contextos que abarquem outras variáveis climatológicas.

Estimativas adequadas do fluxo radiativo em ondas longas (OFFERLE et alii, 2003) podem ser muito úteis para inúmeras investigações. Um exemplo inicial (SOZZI et alii, 1999), trata deste termo quando inserido no balanço radiativo, para obtenção do albedo:

$\alpha=\mathrm{K} \uparrow / \mathrm{K} \downarrow$

como um resíduo:

$\alpha=\left(\mathrm{K} \downarrow+\mathrm{L} \downarrow-\mathrm{L} \uparrow-\mathrm{Q}^{*}\right) / \mathrm{K} \downarrow$

possibilitando uma maneira de avaliação das variações temporais ou espaciais, deste também importante termo do balanço, conforme o método de medição aplicado. As relações entre onda longa emitida e albedo superficial podem conduzir a um campo de pesquisa ainda pouco explorado. Elementos que afetam o primeiro também podem influenciar de maneira similar o segundo. Por exemplo, Brest (1987) descobriu que a magnitude das variações sazonais do albedo urbano é inversamente correlacionada com a densidade de edifícios, pois o impacto das chuvas é limitado nas cidades, pelas superfícies verticais, cujos albedos não mudam substancialmente (ARNFIELD, 1982; BREST, 1987).

Um segundo exemplo a ser mencionado é a relevância de estimativas adequadas do fluxo radiativo em ondas longas (em especial $L \downarrow$ ) para a viabilização de aplicações que utilizam modelagem numérica. Vale aqui ressaltar os resultados da parametrização NARP (Net Allwave Radiation Parameterization) proposta por Offerle et alii (2003). Estes se mostram mais adequados para localidades urbanas do que aqueles alcançados através de modelos de regressão, comparando-se em qualidade representativa ao modelo TEB - ISBA (Town Energy Balance - Interactions between Soil, Biosphere and Atmosphere), que utiliza o mesmo número de entradas meteorológicas, associadas a uma representação de canyon urbano. Mas que, por outro lado, necessita da especificação de um maior número de propriedades superficiais e sub-superficiais.

Classicamente mencionada como um relevante fenômeno climático em áreas urbanas, a ilha urbana de calor (UHI - Urban Heat Island) constitui outro exemplo que pode ser associado ao 
comportamento observado de $\mathrm{L} \downarrow$, especialmente quando caracterizada em termos de seu ciclo diário. Os fatores atmosféricos, em escala regional, que influenciam o desenvolvimento diário da UHI e também o seu desaparecimento são fundamentalmente a intensidade do vento e a nebulosidade (RUNNALLS e OKE, 2000). Uma série de prováveis causas pode implicar no desenvolvimento de ilhas de calor no interior de uma área urbanizada (RIBEIRO e AZEVEDO, 2005; OKE, 1978): aumento da re-irradiação em ondas longas pela poluição atmosférica, diminuição da perda radiativa em ondas longas por obstrução da visibilidade do céu, maior absorção radiativa em ondas curtas por efeitos da geometria urbana, maior capacidade de armazenamento de energia pelos materiais tipicamente urbanos, calor antropogênico, diminuição da evaporação sobre as superfícies impermeabilizadas ou diminuição da perda radiativa superficial por calor sensível devido à redução característica do vento na camada das coberturas urbanas (UCL - Urban Canopy Layer). Mas, ao analisar a validação de um modelo de balanço superficial de energia, proposto por Johnson et alii(1991), Oke et alii (1991) verifica que, no caso do desenvolvimento noturno, a simples consideração do efeito da geometria do canyon urbano sobre o fluxo radiativo em ondas longas já constitui por si só uma hipótese suficiente capaz de gerar uma UHI. No entanto, deve-se ter cautela com tais conclusões obtidas para climas regionais com determinadas características. Havendo alternância do tipo de clima regional, o mesmo raciocínio poderia conduzir a uma situação com ocorrência de "ilha de frio", sob determinadas condições de tempo atmosférico.

Curiosamente, o aumento da re-irradiação em ondas longas, pela poluição, pode paradoxalmente acarretar benefícios à saúde pública, apesar dos evidentes danos que essa fonte irradiadora causa à saúde (RIBEIRO e AZEVEDO, 2005). Pois, em virtude dos raios infravermelhos serem refletidos de volta para a terra (CLAVAL, 1981), a poluição do ar tenderia a dificultar o resfriamento noturno próximo à superfície.

Ao se relacionar estes dois últimos exemplos de aplicação, a carência de observações de L $\downarrow$ em áreas urbanas torna-se mais proeminente, considerando-se o papel da geometria urbana em relação à evolução da UHI. Oke et alii (1991), por exemplo, ao tentar simular numericamente a UHI, e sem contar com observações sistemáticas de L $\downarrow$, dentre outras aproximações, considera um mesmo fluxo radiativo recebido em ondas longas de $300 \mathrm{Wm}^{-2}$, característico para todos os tipos de superfícies. Machado e Azevedo (2005), apesar de analisarem uma área restrita no interior de uma região urbanizada e verificarem um fluxo característico da mesma magnitude que o utilizado por Oke et alii (1991), destacam a importância dos diferentes 
padrões de ocupação do solo como elementos diferenciadores para a distribuição espacial do fluxo $L \downarrow$.

A relação matemática entre a magnitude da UHI e a velocidade do vento é não-linear (inversa a sua raiz quadrada ou então exponencial), sendo que velocidades entre 08 e $10 \mathrm{~ms}^{-1}$ são capazes de eliminar a UHI (RUNNALLS e OKE, 2000), mesmo quando sob uma situação de céu claro. Por sua vez, a relação da UHI com o tipo e quantidade de nebulosidade parece seguir aproximadamente a fórmula de Boltz (RUNNALLS e OKE, 2000), que considera o efeito do fluxo radiativo em ondas longas emitidas pela cobertura de nuvens. É possível, desse modo, obter uma relação aproximadamente linear entre o máximo da UHI e a evolução temporal (OKE,1998), que leve em consideração a intensidade do vento (relação quadrática inversa) e a quantidade de nebulosidade (relação quadrática).

Mas outras relações talvez possam ser alcançadas quando considerados também a poluição atmosférica, o obscurecimento do céu por edificações e árvores, ou também a energia dissipada pelos veículos no interior da mancha urbana. Aliás, nota-se que existem pesquisadores que relacionam em geral o aquecimento urbano a um saldo reduzido do fluxo radiativo em ondas longas, devido ao recebimento de uma parcela maior, pela superfície, a partir de uma atmosfera poluída ou das paredes que compõem o canyon urbano. Mas não se tem verificado trabalhos na literatura que considerem explicitamente a contribuição por parte do calor dissipado pelos veículos para o ambiente imediato. Azevedo (2001) observa que a energia obtida da combustão dos motores à explosão é convertida em calor dissipado a partir do armazenamento ocorrido nos componentes do automóvel, não apenas na forma de calor sensível, mas também na forma de fluxo radiativo em ondas longas.

Voltando ao caso dos modelos numéricos mencionados, tanto durante o período diurno, como no noturno, $L \downarrow$ continua a ser a maior fonte de erro para as estimativas de Q* (OFFERLE et alii, 2003), quando somente se utilizam como entradas os parâmetros próximos à superfície. Conseqüentemente, os efeitos da nebulosidade sobre a troca radiativa em ondas longas não são bem representados. E a representatividade dos resultados numéricos torna-se ainda mais comprometida quando se atenta ao fato de que nenhuma estimativa da nebulosidade noturna é incluída, não havendo reconhecimento explícito da altura da nuvem que pudesse conduzir a sua tipificação. Dessa forma, deficiências como esta, em modelos cada vez mais popularizados no âmbito acadêmico, tendem a valorizar mais uma vez as iniciativas em trabalhos de campo, em especial que conduzam a uma investigação espacial de $L \downarrow$, mais minuciosamente elaborada. 
A quantidade do fluxo $L \downarrow$ recebido, sob condições de céu claro nas cidades, em diversas localidades, pode apresentar valores diversos por causa da variabilidade dos aerossóis atmosféricos. Ao comparar seis fórmulas de emissividade, Crawford e Duchon (1999) encontraram um erro quadrático médio padrão (root mean square error - rmse) variando de 10 a $22 \mathrm{Wm}^{-2}$, para períodos de 04 meses em locais considerados como não urbanos. Mas ao apropriar-se de uma grande variedade de locais, Prata (1996) comparou as mesmas seis fórmulas e também encontrou rmse entre 10 e $20 \mathrm{Wm}^{-2}$. Em muitas situações, os pesquisadores lançam mão de estimativas de $L \downarrow$, mesmo tendo em vista os erros elevados destas, devido em boa parte a $L \downarrow$ ser muito menos observado que $\mathrm{K} \downarrow$.

A parametrização proposta por Offerle et alii (2003) utiliza um modelo atmosférico de uma única camada, tal que:

$\mathrm{L} \downarrow=\varepsilon_{\text {ceu }} \sigma \mathrm{T}_{\text {ceu }}^{4}$

onde $\mathrm{T}_{\text {ceu }}$ é a temperatura atmosférica volumétrica $(\mathrm{em} \mathrm{K}$ ) aproximada pela temperatura próxima à superfície $\left(\mathrm{T}_{\mathrm{a}}\right)$ e $\varepsilon_{\text {ceu }}$ é a emissividade atmosférica estimada de um ponto de vista abrangente, ou seja, que não se detém a especificidades meteorológicas inerentes a este volume, mesmo quando sob a consideração de céu claro, e sobretudo pressupõe a inexistência de obstáculos visuais ao céu, tal como árvores ou edifícios, em relação a um certo ponto de observação situado sobre a superfície.

Os esquemas de emissividade para o céu claro $\left(\varepsilon_{\text {claro }}\right)$, em um nível próximo à superfície, que corresponderia à realidade de um pedestre, têm sido revistos com detalhes em vários lugares e localidades (IDSO e JACKSON, 1969; SUGITA e BRUTSAERT, 1993; PRATA, 1996; CRAWFORD e DUCHON, 1999; NIEMELÄ et al., 2001). De maneira geral, o fluxo radiativo em ondas longas, que é recebido neste nível, é calculado através de expressões empíricas que empregam valores observados da temperatura do ar e da umidade relativa próximas à superfície (JOHNSON et alii, 1991; NIEMELÄ et alii, 2001), e se preocupam no máximo com os efeitos da nebulosidade, sempre considerando uma visão desobstruída do céu, que não leve em conta as contribuições de edifícios, vegetação e outros obstáculos.

A princípio, a formulação de Prata (1996),

$\varepsilon_{\text {claro }}=1-(1+\mathrm{w}) \exp [-(1,2+3,0 \mathrm{w})]^{0,5}$ 
tem sido a que fornece melhor performance (PRATA, 1996; NIEMELÄ et al., 2001), segundo os objetivos deste trabalho, pois inclui testes para um local urbano (NEWTON, 1999). Em suas simulações numéricas com o modelo TEB, para o balanço energético urbano, Masson et alii (2002) também utilizam o método de Prata (1996) para estimar o fluxo radiativo recebido em ondas longas. Na equação 1.4 , w é o conteúdo de água precipitável $\left(\mathrm{g} \mathrm{cm}^{-2}\right)$, aproximado pelos valores atmosféricos médios da pressão de vapor $\left(\mathrm{e}_{\mathrm{a}}\right)$ e de $\mathrm{T}_{\mathrm{a}}$ na altura da camada superficial de referência, através da seguinte relação matemática:

$\mathrm{w}=46,5 \mathrm{e}_{\mathrm{a}}\left(\mathrm{T}_{\mathrm{a}}\right)^{-1}$

Em geral, $\varepsilon_{\text {ceu }}$ deve aumentar em direção a 1 , conforme a cobertura total de nebulosidade, a profundidade da nuvem e a temperatura da base da nuvem aumentarem. Uma estimativa objetiva dos efeitos diurnos da nebulosidade, associados simultaneamente à quantidade e à profundidade da cobertura, é fornecida ao se analisar a razão de $\mathrm{K} \downarrow$ medido em relação ao valor prognosticado $\left(K \downarrow_{\text {claro }}\right)$ para condições de céu claro. $K \downarrow_{\text {claro }}$ é estimado por Crawford e Duchon (1999),

$\mathrm{K} \downarrow_{\text {claro }}=\mathrm{I}_{\mathrm{ex}} \cos (\mathrm{Z}) \tau_{\mathrm{r}} \tau_{\mathrm{pg}} \tau_{\mathrm{w}} \tau_{\mathrm{aer}}$

onde $\mathrm{I}_{\mathrm{ex}}$ é a insolação solar extraterrestre, $\mathrm{Z}$ é o ângulo zenital solar, e $\tau_{\mathrm{r}} \tau_{\mathrm{pg}} \tau_{\mathrm{w}} \tau_{\mathrm{aer}}$ é o produto das transmissividades para o espalhamento Rayleigh (r), a absorção por gases permanentes (pg), e a absorção e o espalhamento por vapor d'água (w) e aerossóis (aer), respectivamente. As transmissividades são dadas em função da época do ano, do ângulo zenital, da latitude, do ponto de orvalho superficial (obtido a partir das observações de $\mathrm{T}_{\mathrm{a}}$ e da umidade relativa) e da pressão atmosférica sobre a superfície em questão. Os dados de Smith (1966), utilizados na formulação de Crawford e Duchon (1999), foram interpolados em uma matriz com resolução latitudinal de apenas 1 grau para um único instante em cada dia do ano, facilitando e simplificando, sem muito prejuízo em relação aos objetivos investigados, a aplicação do modelo desenvolvido por Offerle et alii (2003).

Conseqüentemente, a fração diurna de nebulosidade $\left(\mathrm{F}_{\mathrm{cld}}\right)$, segundo Crawford e Duchon (1999), é dada por:

$\mathrm{F}_{\text {cld }}=1-\mathrm{K} \downarrow / \mathrm{K} \downarrow_{\text {claro }}$ 
Porém, não é possível determinar $\mathrm{F}_{\text {cld }}$ com precisão quando utilizada a equação 1.7 em situações com ângulos zenitais elevados, devido ao efeito co-seno sobre os piranômetros e, especialmente, devido à baixa magnitude de $\mathrm{K} \downarrow$.

Uma situação similar é encontrada ao ser utilizado o índice de claridade:

$\mathrm{CI}=\mathrm{K} \downarrow / \mathrm{I}_{\mathrm{ex}}$

ao invés de $\mathrm{F}_{\mathrm{cld}}$, conforme proposto por Sugita e Brutsaert (1993). Neste caso, os autores vêem-se forçados a limitar sua análise a observações em que $\mathrm{K} \downarrow$ é superior a $30 \mathrm{Wm}^{-2}$.

Battles et al. (2000) também verificaram que as parametrizações da irradiância solar sob céu claro não eram tão boas, para ângulos zenitais elevados, limitando os cálculos das transmissividades para ângulos zenitais inferiores ao limiar de $80^{\circ}$.

Todos estes resultados tendem a superestimar a cobertura de nebulosidade para ângulos zenitais elevados, o que, por sua vez, vicia as estimativas de $L \downarrow$ nestes horários, criando um falso panorama. À noite, quando não é possível estimar a nebulosidade através da equação1.8, é feita uma estimativa a partir do valor calculado para o horário do pôr do Sol, o que, por outro lado, já pode muito bem estar enviesado.

No desenvolvimento paramétrico sugerido por Offerle et alii (2003), pelo ajuste da emissividade do céu claro aos efeitos de cobertura de nebulosidade, através da utilização de um termo quadrático, tem-se:

$\varepsilon_{\text {ceu }}=\varepsilon_{\text {claro }}+\left(1-\varepsilon_{\text {claro }}\right) \mathrm{F}_{\text {cld }}^{2}$

Desta maneira pretende-se minimizar o efeito do desvio da cobertura da nebulosidade, enquanto ainda permite-se $\varepsilon_{\text {ceu }}=1$, para uma situação de céu totalmente encoberto.

Mediante a ressalva dos próprios autores do método (OFFERLE et alii, 2003), a performance desta e de outras parametrizações, em relação aos efeitos da nebulosidade sobre a emissão celeste em ondas longas, depende de um aprofundamento da climatologia das nuvens para cada localidade. O método acima não considera os efeitos do tipo de nuvem - caracterizado pela altura de sua base - em relação à emissão. Sugita e Brutsaert (1993) verificaram que ao considerar o tipo de nuvem as estimativas melhoram substancialmente, porque as nuvens mais baixas teriam um impacto muito maior sobre a emissividade característica do céu. 
Lançando agora um olhar sobre a outra face do balanço em ondas longas, e seguindo mais uma vez o procedimento proposto por Offerle et alii (2003), tem-se, de uma maneira abrangente, que a radiação em ondas longas emitidas a partir de uma superfície é determinada basicamente pela temperatura radiativa superficial efetiva $\left(\mathrm{T}_{\mathrm{o}}\right)$, sendo apenas uma pequena fração do fluxo total consequiência da reflexão de $L \downarrow$, a partir da mesma superfície:

$\mathrm{L} \uparrow=\varepsilon_{\mathrm{o}} \sigma \mathrm{T}_{\mathrm{o}}^{4}+\left(1-\varepsilon_{\mathrm{o}}\right) \mathrm{L} \downarrow$

Como, em geral, $\mathrm{T}_{\mathrm{o}}$ não é disponível, Offerle et alii (2003) sugerem sua substituição por $\mathrm{T}_{\mathrm{a}}$, acarretando, conseqüentemente, um viés na radiação emitida calculada.

Tradicionalmente (SELLERS, 1965; HOLTSLAG e van ULDEN, 1983) este viés é corrigido utilizando-se a seguinte aproximação:

$\varepsilon_{\mathrm{o}} \sigma \mathrm{T}_{\mathrm{o}}^{4} \approx \varepsilon_{\mathrm{o}} \sigma \mathrm{T}_{\mathrm{a}}^{4}+4 \varepsilon_{\mathrm{o}} \sigma \mathrm{T}_{\mathrm{a}}^{3}\left(\mathrm{~T}_{\mathrm{o}}-\mathrm{T}_{\mathrm{a}}\right)$

Onde a magnitude desta correção é estimada por uma fração (c) da radiação solar absorvida pela superfície, supondo-se que esta seja totalmente opaca a tal radiação (excluem-se aqui superfícies líquidas, por exemplo):

$4 \varepsilon_{\mathrm{o}} \sigma \mathrm{T}_{\mathrm{a}}^{3}\left(\mathrm{~T}_{\mathrm{o}}-\mathrm{T}_{\mathrm{a}}\right)=\mathrm{cK} \downarrow\left(1-\alpha_{\mathrm{o}}\right)$

Conforme Offerle et alii (2003) observa, esta correção representa uma modificação do procedimento sugerido inicialmente por Holtslag e van Ulden (1983), o qual não incorporava $\alpha_{0}$. No entanto, como ainda observam, van Ulden e Holtslag (1985) revisaram sua formulação original, que passou a incorporar $\alpha_{o}$ e a inclinação da curva de entalpia de saturação (c), mantendo-se a utilização das componentes de onda curta de $\mathrm{Q}^{*}$.

$\mathrm{Na}$ formulação de Offerle et alii (2003) é apresentado um exemplo para a correção equivalente da diferença entre $T_{o}$ e $T_{a}$, no qual são utilizados os valores de 0,15 para $\alpha_{0}$ (albedo característico de áreas densamente edificadas), $1000 \mathrm{Wm}^{-2}$ para $\mathrm{K} \downarrow$ (fluxo radiativo típico sobre uma superfície de latitude baixa, durante o ápice solar de um dia de céu claro da estação quente), $300 \mathrm{~K}$ para $\mathrm{T}_{\mathrm{a}}$ (valor característico para as condições consideradas em $\mathrm{K} \downarrow$ ), e 0,08 para c (valor aproximado sugerido por Hlotslag e van Ulden, 1983). Neste caso específico, que serve-nos como ilustração, a correção obtida é da ordem de $11 \mathrm{~K}$, o que representa uma variação sob hipótese alguma desprezível. 
Todavia, ainda ressalta-se que este método não leva em consideração o efeito da variabilidade temporal na diferença entre $T_{o}$ e $T_{a}$, pelo qual $T_{o}$ experimenta um máximo próximo ao pôr do sol, podendo a seguir tornar-se inferior a $\mathrm{T}_{\mathrm{a}}$ durante a noite.

A ausência de correção pode ser aceitável em áreas urbanas (OFFERLE et alii, 2003), especialmente durante o período noturno, no interior das zonas centrais, densamente edificadas e verticalizadas. Isto porque a liberação noturna de calor armazenado pelo ambiente urbano é substancial, suficiente para produzir fluxos convectivos de calor sensível orientados para cima (GRIMMOND e OKE, 2002) e perfis de temperatura que tendem à neutralidade (OKE, 1995).

A falta de correção noturna para a diferença entre $T_{o}$ e $T_{a}$ teria pouco impacto (OFFERLE et alii, 2003), mediante os erros associados à determinação da emissividade do céu e à cobertura de nuvens. No entanto, ao acoplar esta parametrização a um modelo de fluxo de calor superficial, a estabilidade poderia ser calculada e uma melhor estimativa de $\mathrm{T}_{\mathrm{o}}$ poderia ser feita (van ULDEN e HOLTSLAG, 1985; de ROOY e HOLTSLAG, 1999).

Portanto, a especificação completa de L $\uparrow$, seguindo este procedimento de Offerle et alii (2003), pode ser finalmente escrita como:

$\mathrm{L} \uparrow=\varepsilon_{\mathrm{o}} \sigma \mathrm{T}_{\mathrm{a}}^{4}+0,08 \mathrm{~K} \downarrow\left(1-\alpha_{\mathrm{o}}\right)+\left(1-\varepsilon_{\mathrm{o}}\right) \mathrm{L} \downarrow$

E assim, o esquema completo de parametrização de Offerle et alii (2003), apresentado aqui, pode resumidamente ser especificado pela Eq. 1.1, para balanços de onda curta, pelas Eqs. 1.3 a 1.7, para o fluxo recebido em ondas longas e pela Eq. 1.13, para o fluxo emitido em ondas longas. A eficácia de um modelo simples, para calcular L $\uparrow$ através de uma temperatura do ar, “corrigida", próxima à superfície, ao invés da temperatura superficial verdadeira, é demonstrada pelos resultados obtidos por Offerle et alii (2003). Neste caso, verifica-se, para os locais mais densamente urbanizados, ser desnecessária a aplicação de correções para o período noturno, que considerem as diferenças entre $\mathrm{T}_{\mathrm{o}}$ e $\mathrm{T}_{\mathrm{a}}$. Além disso, em relação ainda à parametrização sugerida por Offerle et alii (2003), é interessante mencionar, tendo em vista os propósitos deste trabalho, que o impacto diurno das nuvens sobre L $\downarrow$ é incorporado, utilizando-se um método que repousa sobre a noção de que os efeitos da nebulosidade sobre a transmitância solar podem também formar as bases para um novo parâmetro a ser aplicado na faixa espectral das ondas longas. Todavia, ainda nenhuma parametrização de L $\downarrow$, que considere objetivamente a ocupação do solo, foi encontrada na literatura. 
Por outro lado, a própria determinação da temperatura superficial - quando não realizada in loco através de termístores - por si só já envolve uma aproximação. Em geral, sua determinação é feita com a utilização de sensores remotos, e comumente denominada como aparente. Vários fatores podem explicar esta denominação, em especial o fato de o sensor remoto sempre fornecer uma visão enviesada, e não completa, do alvo superficial. Soux et alii(2004) desenvolvem um modelo numérico (SUM - Surface, sensor, sun Urban Model) capaz de fornecer a configuração espacial do que realmente é "visto" por um sensor remoto a partir de um alvo superficial, sob dependência das características de seu posicionamento, produzindo então uma correção para a temperatura observada. Neste caso, a temperatura superficial aparente fornecida pelo modelo é monitorada por um scanner termal infravermelho (FLIR - SC500), equipado com uma lente $24^{\circ}$ x $18^{\circ}$, capaz de compor uma imagem com resolução espacial de 320 x 240 pixels.

Estimativas de temperaturas, obtidas por imagens provenientes de sensores remotos podem ser utilizadas como entrada de modelos como o SUM. A partir deste procedimento é possível calcular temperaturas médias corrigidas para as diversas faces do modelo, que correspondam às faces da geometria urbana, tais como paredes, coberturas e calçamentos. Ou então, em termos abrangentes, calcular uma temperatura corrigida que seja mais representativa para uma certa área circular, no interior de uma imagem, obtida a partir de uma determinada direção na qual o sensor está posicionado - e de um certo ângulo de visada em relação ao alvo pretendido.

Em observações aéreas (VOOGT e OKE, 1997) é mais comum a utilização do scanner termal AGEMA (800 - LWB), pela maior facilidade no acoplamento em aeronaves como helicópteros, por exemplo.

De uma maneira geral estes scanners e sensores do infravermelho são sensíveis à faixa espectral do infravermelho termal cuja banda principal vai desde $08 \mu \mathrm{m}$ até $14 \mu \mathrm{m}$. Esta banda é utilizada em métodos de determinação de uma temperatura, realmente significativa, para idealizações de uma superfície urbana completa (VOOGT e OKE, 1997), que inclua todas as faces, mesmo as negligenciadas pelo posicionamento dos sensores. Neste caso, a estimativa da área total da superfície, bem como a termometria do infravermelho, são etapas precedentes na aplicação do método.

A banda situada entre $08 \mu \mathrm{m}$ até $14 \mu \mathrm{m}$ é muito significativa, pois corresponde a uma janela do espectro de absorção do fluxo termal pelo vapor d'água e pelo gás carbônico. Aplicando a 
lei de Wien, Geiger (1950) verifica que esta região do espectro em que a absorção do infravermelho é significativamente atenuada, mais precisamente entre os comprimentos de onda entre 9,2 $\mu \mathrm{m}$ e $12,4 \mu \mathrm{m}$ - correspondente a uma faixa de temperatura dos corpos radiantes entre $40^{\circ} \mathrm{C}$ e $-40{ }^{\circ} \mathrm{C}$, respectivamente. Isto demonstra que os sensores que atuam nesta faixa específica são eficazes para um levantamento adequado do estado térmico do ambiente, cuja amplitude térmica dificilmente, excluindo-se eventos extremos, excederá a esses limites.

As observações aéreas realizadas por Voogt e Oke (1997) foram realizadas não apenas na direção do nadir, como também a $45^{\circ}$ a partir deste. Já havia preocupação em relação àquilo a que o sensor realmente enxergava, porém nenhuma correção em relação à geometria do alvo era ainda praticada.

A propósito das correções que devem ser realizadas sobre estimativas remotas da temperatura superficial, duas são fundamentais e devem ser mencionadas: a correção atmosférica e a correção relativa à emissividade superficial do alvo observado.

No caso do estudo de Voogt e Oke (1997), as correções para os efeitos atmosféricos são aplicadas através da utilização de um programa numérico denominado LOWTRAN (versão 7), capaz de estimar a contribuição ou a atenuação para a emissão térmica em relação a um determinado número de camadas, definido a partir de uma sondagem vertical do local. No entanto, correções para a emissividade da superfície são mais complexas, devido à grande heterogeneidade da cobertura superficial urbana. No referido estudo, esta última correção não é realizada, sendo que os autores estimam que o erro acarretado por isto, na estimativa da temperatura da superfície, deve ser da ordem de $1,5^{\circ} \mathrm{C}$.

A temperatura superficial aparente das paredes dos canyons, bem como das coberturas, também pode ser estimada utilizando-se termômetros de radiação infravermelha (Everest Interscience - 4000A). Oke et alii (1999) utiliza-os em orientações diversas (leste-oeste, norte-sul), conforme a disposição espacial dos canyons, e em conjunto com medições climatológicas (temperatura do ar, umidade relativa e vento) a cerca de $6 \mathrm{~m}$ acima das coberturas. É interessante notar que neste experimento um sensor de umidade superficial é posicionado em contato com a superfície da cobertura, o que permite lançar novas hipóteses sobre as estimativas que utilizam radiação infravermelha, tal como variabilidade da emissividade em associação ao conteúdo de umidade. 
Imagens orbitais, do canal termal, também devem ser suscetíveis a todas estas correções já mencionadas, para que possam ser utilizadas de forma adequada na investigação do clima urbano. Áreas cobertas por vegetação, por exemplo, tendem a indicar temperaturas superficiais mais baixas (TARIFA e ARMANI, 2001; LOMBARDO, 1985). Essas áreas, por sua vez, exercem um papel de atenuação de uma ilha urbana de calor, quando analisadas na escala local que abrange o aglomerado urbano, sobretudo no período diurno, devido ao resfriamento causado pela perda de energia por evapotranspiração (RIBEIRO e AZEVEDO, 2005).

A magnitude e a estrutura espacial das variações dos fluxos são diferentes para as componentes individuais do balanço de energia. O fluxo de calor antropogênico e as mudanças no saldo de calor armazenado devem apresentar padrões que sigam com proximidade a estrutura da morfologia superficial, e as variações podem oscilar entre várias ordens de magnitude. Variações do fluxo de calor sensível turbulento diurno, superiores a $40 \%$, em escalas de 100 a $1000 \mathrm{~m}$ e a cerca de $30 \mathrm{~m}$ de altura, podem ser encontradas (SCHMID et alii, 1991). O termo do balanço superficial de energia, com menor sensibilidade espacial é o saldo radiativo. Embora a média espacial inerente às medições diretas do saldo radiativo (a área fonte é o fator de visão), normalmente inclua um domínio menor do que a área fonte da difusão turbulenta, para a mesma altura, verifica-se que a variabilidade espacial do saldo radiativo é cerca de quatro vezes menor do que a variabilidade espacial do fluxo de calor sensível turbulento. Neste estudo, os autores determinam a variabilidade espacial dos fluxos turbulentos utilizando um método de ponderação das fontes contribuintes de uma determinada superfície, posicionada (ver Fig. 04, pág. 259, de SCHMID et alii, 1991) a barlavento do ponto de observação situado sobre o mesmo plano. Analogamente, em relação às observações dos fluxos radiativos, os autores consideram diversas frações para os efeitos oriundos de uma área fonte. Tais áreas mencionadas agregam os elementos que são considerados as fontes dos fluxos observados por um sensor, e são definidas com maior ou menor intensidade em diversos níveis de altura, acima ou abaixo do nível ao qual o sensor é instalado. O modo conservativo, que é observado nos padrões do saldo radiativo, é atribuído a uma resposta negativa entre as porções de onda longa e onda curta que compõem o cálculo do balanço.

Considerando-se os termos do balanço radiativo de forma individualizada, o binômio morfologia e distribuição espacial assume um papel mais relevante. A validação do modelo de balanço superficial de energia de Johnson et al. (1991), por exemplo, é útil para análise da hipótese em relação à causa da ocorrência da ilha urbana noturna de calor, pela qual apenas a 
consideração dos efeitos da geometria do canyon urbano sobre o fluxo radiativo de onda longa já é suficiente para se gerar uma ilha de calor (OKE et alii, 1991).

Tratando agora não mais exclusivamente do ar que preenche a camada abaixo das coberturas, mas também da superfície urbana propriamente dita, a sua natureza tridimensional pode implicar, quando combinada com considerações geométricas de caráter solar, celeste e do próprio sensor, em diversos padrões microescalares de temperatura observados sobre a mesma. Estes diversos padrões são influenciados pelas propriedades térmicas dos diversos materiais que compõem a superfície, e também pela orientação das faces destas superfícies, em relação ao sol (durante o dia) e ao céu (durante a noite). A observação destes padrões pode ser corrompida pelo fato dos sensores utilizarem em geral fatores de visão muito estreitos para observar superfícies rugosas (tridimensionais), portanto com uma visão enviesada da área observada, resultando uma situação de anisotropia efetiva (incompatibilidade entre a estrutura superficial e as propriedades Lambertianas) da radiação de onda longa emitida pela superfície urbana. Objetivando-se uma padronização mais apropriada, a anisotropia térmica urbana tem sido observada e modelos têm sido propostos, visando melhor compreender a relação entre temperatura superficial, o balanço superficial de energia e a temperatura do ar dentro e acima da camada das coberturas urbanas (VOOGT e OKE, 2003).

Offerle et alii (2006) idealizaram um experimento urbano, montando instrumentos a uma altura de $37 \mathrm{~m}$, em uma torre tubular de $8 \mathrm{~cm}$ de diâmetro. A torre possuía $20 \mathrm{~m}$ de altura, fixa sobre um edifício de $17 \mathrm{~m}$. O fluxo radiativo em ondas longas pôde ser estimado de maneira direta e estática, como uma das componentes de um pirradiômetro CNR1 (KIPP \& ZONEN, 2001) instalado na torre, e também de maneira indireta e dinâmica, através de perfis verticais obtidos com um termômetro infravermelho 4000A (Everest Interscience). Neste experimento, todos os equipamentos foram conectados a dataloggers 21X e 23X (Campbell Sci, Inc.), e os perfis foram segmentados em 8 níveis, possibilitando, assim, um detalhamento suficiente das temperaturas do ar e das superfícies, nas quais incluem-se as quatro paredes de um prédio e o pavimento de uma rua.

Com uma torre de altura semelhante (22 m), Ross e Oke (1988) também utilizaram um pirradiômetro para obter o saldo radiativo vertical do fluxo em ondas longas, através da diferença entre os sinais observados no sensor superior (voltado para cima) e no inferior (voltado para baixo). Latimer (1972) estima que o erro envolvido nesse tipo de mensuração, baseada no diferencial entre sensores distintos, seja da ordem de $5 \%$. 
Como se pode notar, dentre os equipamentos mais utilizados em medições dos fluxos radiativos estão os pirradiômetros, pois são considerados compactos, ao apresentarem quatro sensores (dois para ondas curtas e dois para ondas longas, com cada elemento voltado para faces opostas) fixos em um único corpo de aparelho, e além de tudo objetivos para finalidades de cálculos de balanço, porque fornecem instantaneamente a magnitude de $Q^{*}$. Um pirradiômetro que tem sido muito empregado, com finalidades de prospecção climática, é o modelo CNR1 fabricado pela Kipp-Zonen (OFFERLE et alii, 2003). A precisão esperada do CNR1 para totais diários é de $\pm 10 \%$ (KIPP \& ZONEN, 2001). Oncley et alii (2002) verificaram que o CNR1 funciona bem para a obtenção de $Q^{*}$, embora para os fluxos das componentes houvesse um erro maior. Em especial, as medidas de onda longa são afetadas pelo aquecimento da cobertura do sensor, particularmente em horários com vento fraco e quando instalado sobre plataformas fixas. No CNR1 a temperatura do corpo é utilizada para corrigir este efeito. Para evitar condensação sobre os invólucros dos sensores, ele dispõe de aquecimento artificial, apenas para o período noturno, pois esta capacidade tende a afetar mais as leituras em ondas curtas do que em ondas longas (KIPP \& ZONEN, 2001).

No entanto, para alguns modelos de pirradiômetros, como o Q*6 REBS (OFFERLE et alii, 2003), as densidades noturnas do fluxo em ondas longas são em geral subestimadas em cerca de 45\%, quando em comparação com pirgeômetros Eppley calibrados (HODGES e SMITH,1997). Sendo que durante o dia esta diferença reduz-se a cerca de 5\% apenas. Porém, parece ainda haver muita discordância em relação a estas medições. Duchon e Wilk (1994) também notam discrepâncias similares à noite, enquanto que em testes de campo controlados (OFFERLE et alii, 2003), no interior de câmaras escuras protegidas, os resultados são opostos. Por esta falta de concordância, Offerle et alii (2003) optam por não aplicar qualquer tipo de correção em seus resultados para as ondas longas obtidas com o Q*6. Outros levantamentos dos fluxos em ondas longas com outros aparelhos (HODGES e SMITH, 1997; LI-COR, 1991) parecem sugerir viés negativo em relação ao CNR1, ou um erro absoluto em torno de 5\% para o sensor LI-200, por exemplo.

O pirgeômetro fabricado pela Eppley Lab, Inc., modelo PIR (Precision Infrared Radiometer), parece realmente representar o "estado da arte" para medições dos fluxos em ondas longas, no intervalo espectral do infravermelho termal, sendo utilizado como parâmetro em inúmeros experimentos. No caso de experimentos urbanos, Voogt e Oke (1991), por exemplo, utilizam este equipamento para validações do fluxo radiativo noturno em ondas longas para o caso de um modelo físico - numérico de canyon urbano. 
Um experimento urbano anterior, que ilustra de maneira minuciosa várias alternativas para investigação de fluxos radiativos em ondas longas, e sempre destacando o intervalo espectral do infravermelho termal, foi aquele idealizado por Soux et alii (2004) para validação do modelo SUM.

Foram realizadas medições com um conjunto de instrumentos acoplados sobre um braço cruzado, montado em uma torre pneumática e telescópica com a altura do topo a $26 \mathrm{~m}$ acima da superfície. Simultaneamente, foram também distribuídos termômetros infravermelhos (IRT - InfraRed Termometer), tanto manuais como fixos sobre tripés, ao redor da área estudada.

Este tipo de torre utilizada por Soux et alii (2004) permite que os instrumentos acoplados sejam erguidos ou abaixados, e também rotacionados até $360^{\circ}$ na direção azimutal. Para obtenção de dados a serem validados em modelos de visão, como o SUM, os instrumentos são em geral montados para baixo, deslocando-os $45^{\circ}$ a partir do nadir. Neste estudo mencionado, o conjunto de equipamentos consiste de um termômetro infravermelho com fator de visão de $15^{\circ}$ (Everest Interscience - 4000A EIRT), um piranômetro (LI COR - 200SB) e uma câmara com lente reflex simples de $35 \mathrm{~mm}$ (Minolta - X700) que pode ser ativada remotamente. Além destes, com relação ao pirgeômetro, ao pirradiômetro e ao EIRT de fator de $60^{\circ}$, uma descrição sucinta pode ser apreciada em Soux (2000). Especialmente em relação ao pirgeômetro, um exemplo de aplicação deste sensor sobre uma plataforma móvel é fornecido por Machado e Azevedo (2005).

A propósito, estes sensores EIRT operam com resposta espectral para a principal banda do infravermelho termal, entre $08 \mu \mathrm{m}$ e $14 \mu \mathrm{m}$, restringindo a interferência de ondas de outros comprimentos. Além disso, o modelo 4000 A possui um fator de visão reduzido, em torno de $15^{\circ}$, o que permite a investigação de alvos mais específicos sobre as superfícies. Voogt e Oke (1997; 1998 b), inclusive, fazem uso deste tipo de sensor sobre plataformas móveis, tal como caminhões ou outros veículos automotores diversos, através de diferentes áreas de ocupação (industriais, residenciais e comerciais) e sob diversos ângulos de elevação em relação aos alvos $\left(0^{\circ}, 15^{\circ}, 30^{\circ}\right.$ e $\left.45^{\circ}\right)$. Estas observações móveis com este tipo de sensor são muito úteis para determinação das temperaturas das paredes dos edifícios e também do piso e calçamento das ruas. Além de viabilizar uma orientação mais precisa do próprio levantamento aéreo (VOOGT e OKE, 1998 a). Pois, com estas informações é possível determinar os horários com maiores diferenças de temperatura entre as faces norte - sul e leste - oeste dos canyons urbanos, que em geral ocorrem no intermédio da manhã, início e também ao final da tarde. 
Mas, para que as diversas superfícies pudessem ser observadas sob a perspectiva de diferentes direções e em horários distintos, Soux et alii (2004) realizaram as medições em três níveis acima do calçamento do canyon (11 m, $22 \mathrm{~m}$ e $26 \mathrm{~m}$ ), em oito azimutes igualmente espaçados entre $0^{\circ}$ e $315^{\circ}$, bem como em sete horários irregularmente distribuídos, sendo cinco durante o dia e dois à noite. Este esquema idealizado é capaz de fornecer aos pesquisadores, no decorrer de um período diário completo, um conjunto de 168 "visões" distintas de uma mesma superfície (!). Vale ainda ressaltar que além destes instrumentos montados na torre, alguns IRTs foram posicionados sobre diversas superfícies, para que a temperatura das diversas faces, que compõem o ambiente dos canyons urbanos, pudesse também ser avaliada individualmente. E que, toda esta análise, apesar de todo o esforço envolvido, foi representativa de uma condição meteorológica influenciada, em escala mais ampla, pelo domínio de um anticiclone. Observando-se que condições meteorológicas opostas podem implicar em uma variabilidade distinta da quantidade de posicionamentos planejados para os sensores.

Sensores infravermelhos podem ser utilizados em outras composições experimentais correlatas à investigação do ambiente urbano, como a dos fluxos turbulentos. Um bom exemplo é a idealização de Grimmond et alii (2004) que aplica métodos similares aos descritos por Schmid et alii (2000) e Offerle et alii (2006), para adquirir e processar um conjunto mais abrangente de dados meteorológicos. Neste caso, anemômetros sônicos (RM Young - 81000) são utilizados em medições das componentes espaciais do vento, paralelamente à investigação da temperatura virtual. Simultaneamente às medições de momentum, são também investigadas flutuações em massa, para o vapor d'água e o dióxido de carbono $\left(\mathrm{F}_{\mathrm{CO} 2}\right)$, empregando-se dois analisadores infravermelhos de gases (Licor - 7500). As componentes gerais do balanço radiativo são avaliadas através de um pirradiômetro (KippZonen - CNR1). A maioria dos equipamentos é conectada a um datalogger (Campbell Scientic, Inc - 23X), para que a aquisição seja efetuada, à exceção do sistema de anemômetros sônicos (SAT - Sonic Anemometer Temperatura) que são conectados diretamente à porta serial de um computador. Assim, é possível que o cálculo destas flutuações possa ser efetuado com o uso da técnica eddy covariance, que requer uma freqüência de amostragem superior, da ordem de $10 \mathrm{~Hz}$.

Os intervalos decorridos entre medições sônicas e medições com o analisador infravermelho são definidos por Grimmond et alii (2004) como o intervalo correspondente à máxima correlação entre medições com um termopar e as medições de temperatura SAT, definindo-se um intervalo de tempo para o cálculo das médias dos fluxos. Além disso, Grimmond et alii 
(2004) seguem a recomendação de Kaimal e Finnigan (1994), segundo a qual o sistema de coordenadas correspondentes às variâncias e co-variâncias obtidas deve ser rotacionado, para que um novo sistema de coordenadas dispostas no sentido da corrente de ar possa ser obtido, permitindo-se assim o cálculo adequado dos fluxos $\mathrm{Q}_{\mathrm{h}}$ e $\mathrm{Q}_{\mathrm{e}}$, bem como da estatística turbulenta, neste caso em intervalos de uma hora.

Nota-se ainda, que no experimento conduzido por Grimmond et alii (2004), correções também precisam ser aplicadas sobre as estimativas sônicas da temperatura virtual e da densidade utilizada no cálculo final de $\mathrm{Q}_{\mathrm{e}}$ e $\mathrm{F}_{\mathrm{CO} 2}$, através dos procedimentos recomendados por Schotanus et alii (1983) e Webb et alii (1980), respectivamente.

Informações secundárias podem ser obtidas a partir dos parâmetros instrumentalmente avaliados. Os dias de céu claro podem ser identificados por análise visual das curvas do fluxo da radiação solar recebida. No caso dos experimentos realizados por Offerle et alii (2003, 2005) na cidade de Los Angeles, por exemplo, este procedimento é fundamental na obtenção de informações adicionais, haja vista que a disponibilidade de observações sobre a cobertura de nuvens, para o local estudado (GRIMMOND et al., 1996), restringia-se ao período matutino. 


\subsection{Meio e relações}

\subsubsection{METRÓPOLE E REDE URBANA}

Em uma condição típica de países não desenvolvidos, algumas metrópoles nacionais concorrem para a primazia sobre um aglomerado de pequenos núcleos, constituindo um conjunto urbanizado caótico sob vários aspectos, sobretudo em relação à qualidade ambiental. Apesar da análise taxonômica em grande escala não fornecer esta impressão (MONTEIRO,1981).

A configuração arquitetônica que compõe os seus espaços, também reflete esta desorganização. Marx (1991) percebe que a grande valorização territorial das áreas centrais das metrópoles é uma das importantes implicações das mudanças significativas que as cidades vêm sofrendo. Spirn (1995) apresenta os problemas das metrópoles como de difícil solução, mediante tentativas particulares e temporárias de se buscar novamente a natureza original, apenas tornando os problemas ambientais repetitivos em intervalos irregulares, porém consecutivos, à medida que a urbanização se desenvolve.

Os mesmos processos de ocupação e técnicas de edificação têm sido utilizados repetidamente (SPIRN, 1995), mesmo no estabelecimento das novas cidades e na amplificação do caráter metropolitano através de seus limites físicos, enquanto os processos da natureza, que fundamentam a base desta ocupação, ainda são insuficientemente observados. Um bom exemplo que ilustra esta condição é o das cidades jardim que efetivamente impulsionaram um tipo promissor de movimento urbano, mas, segundo Spirn (1995), ainda é influente. Há muito, os padrões de cidades jardim representam a negação da velha cidade, relegada ao espaço central da metrópole que atualmente se revitaliza e, sob os pontos de vista financeiro ou residencial, se valoriza (HOWARD, 1902 - in SPIRN, 1995) em harmonia com a natureza original. É o caso de muitas cidades medievais européias como Köln, cujas amenidades ainda presentes no início do século XVI já haviam desaparecido por completo de centros urbanos já bem mais populosos, tal como Londres ou Paris. Ou então, de outras tantas re-elaboradas sob o princípio das cidades jardim já no início do século $\mathrm{XX}$, como por exemplo Welwyn e Letchworth, na Bretanha, ou Greenbelt e Columbia, em Maryland, ou ainda Radburn, em New Jersey, ou Reston, na Virgínia, Estados Unidos. Porém, no caso da cidade de São Paulo a distribuição das cidades jardim é um pouco mais complexa. 
Devido à complexidade em se compreender e planejar as inter-relações de caráter físico e sócioeconômico, estas tentativas continuam ainda a se constituir, muitas vezes, como meros rompantes românticos, decorativos ou paisagísticos sem conexão com a visão realista dos princípios físicos e sociais que as deveriam nortear para a construção da metrópole ideal (PEREIRA LEITE, 2005).

Mas no mundo real o que se observa, porém, são psicosferas distintas, que se manifestam através de ilhas idealizadas em meio a um território imensurável, onde a metrópole total (SOTTSASS, 1991) se expande indefinidamente, como segunda natureza que se sobrepõem àquela original.

Voltando-se especificamente para a realidade nacional, percebe-se um caráter periférico predominantemente dependente. Não apenas entre o núcleo central da metrópole e seu entorno, mas também entre os diversos núcleos urbanos, com as metrópoles mais populosas sendo designadas em termos taxonômicos como "sathelic primate cities" (MONTEIRO, 1981). Este caráter, ainda segundo Monteiro (1981), reflete as desigualdades regionais, do ponto de vista da organização funcional. Neste contexto, Spirn (1995) reflete sobre as soluções para os problemas das cidades, e conseqüentemente dos subúrbios, espacialmente dissociados, porém fisicamente e socialmente amalgamados a elas, e que, segundo a autora, só podem ser agora alcançadas compreendendo-se o lugar de cada um dentro da região, encarando-se a cidade, os subúrbios e o campo como um sistema em evolução, interligado pelos processos da natureza e pelos interesses econômicos e sociais.

Assim, no âmbito do pensamento de uma metrópole total, que se pode imaginar também em termos dos processos físicos, as reminiscências territoriais do campo são atualmente envolvidas pelos limites externos dos subúrbios em uma espécie de movimento emergente a partir do núcleo urbano primordial. A partir do que resta do retalhamento territorial do campo, as metrópoles modernas tomam uma nova forma (SPIRN, 1995), que desde o século passado apresenta a tendência de crescimento não mais como oriunda do centro urbano, mas pertinente à realidade do subúrbio periférico, talvez gerador de novos núcleos no interior do intrincado mosaico que tem se tornado o espaço metropolitano. A dinâmica deste mosaico, que envolve diferentes graus de variação térmica e complexa distribuição espacial de fluxos de matéria e energia, ainda não é totalmente conhecida apesar dos processos físicos da atmosfera urbana já serem estudados intensivamente desde a década de 50 (LANDSBERG,1981), e de maneira dispersa desde meados do século XIX. 
Segundo Monteiro (1981), o que é observado na área da metrópole paulistana, em termos de processos, são condições em geral semelhantes ao que também ocorre nos demais aglomerados urbanos nacionais, diferindo apenas em relação ao grau de intensidade. O que parece ainda ser uma hipótese bastante atual neste início de século XXI. E, além disso, em termos dos enormes problemas sociais, emerge através dos anos a sensação latente de incapacidade do orçamento destinado à solução, e que através dos níveis populacionais crescentes vê-se pulverizado de maneira relativa, apesar de ser de origem tipicamente vultosa.

\subsubsection{DISTRIBUIÇÃO}

Espera-se que o ritmo dos fluxos radiativos em ondas longas, na escala de atuação de um pedestre, a microescala, esteja relacionado com a distribuição espacial da temperatura superficial no interior dos canyons urbanos.

Ou seja, vamos partir de uma premissa pela qual as condições espaciais iniciais dos elementos que favorecem a origem de um fenômeno, irão ter implicações no ritmo (SORRE, 1934) do próprio fenômeno. No caso de fluxos, a evolução no tempo deve estar fortemente influenciada pelos elementos que o originam. Em termos de ondas longas seria a temperatura das diversas superfícies e da própria atmosfera.

Esta distribuição reduzida, quando estendida à escala local de uma cidade, através de vários elementos em conjunto, irá contribuir de maneira extremamente relevante, por sua vez, à distribuição espacial, intensidade e evolução temporal das ilhas de calor que se estabelecem neste ambiente urbano.

Dados climáticos tradicionais de temperatura do ar, obtidos em aeroportos, não são representativos das temperaturas observadas nos diversos tipos de superfícies dos canyons, e precisam ser corrigidas (VOOGT e OKE, 1991). Ou então, de um modo mais adequado, campanhas em campo devem ser conduzidas, de maneira que dados mais precisos sobre a distribuição espacial das temperaturas nestas superfícies sejam levantados. Será reduzida desta maneira, dentre outros aspectos, uma das principais limitações em modelagem numérica (VOOGT e OKE, 1991) quando aplicada à cobertura espacial urbana e aos seus meandros em escala detalhada. 
Parcela considerável do fluxo em onda longa observada em uma cidade é proveniente de fontes antrópicas de calor $\left(\mathrm{Q}_{\mathrm{F}}\right)$, não se restringindo apenas à fonte natural da atmosfera, mas também aos poluentes e partículas antropogênicas que a contaminam.

Diferentemente de Azevedo (2001), Grimmond (1992) calcula a magnitude do fluxo QF para um subúrbio de Vancouver, em uma escala espacial reduzida, onde observações instantâneas, ao invés de estimativas anuais, são realizadas. No entanto, percebe-se que o seu cálculo baseia-se na combustão de fontes móveis e estacionárias, bem como nas taxas metabólicas, assim como em Azevedo (2001) para o caso da RMSP em uma escala mais abrangente.

Em qualquer uma das abordagens, a magnitude do fluxo em $Q_{F}$ será dependente da distribuição espacial das fontes emissoras (SCHMID et alii, 1991). Mas, como neste estudo, o interesse se desenvolve no interior da camada das coberturas urbanas, onde os locais de medições posicionam-se sempre relativamente às principais fontes potenciais de calor, tais como edifícios e vias de tráfego, e também relativamente à evolução sazonal, é razoável então verificar a magnitude de $Q_{F}$ encontrada para diversos lugares (OKE, 1988). Apesar de quase nunca se verificar medições em situações extremamente localizadas, com salas ou meios de transporte sob ocupação humana máxima, encontra-se na literatura em geral, e em termos da componente vertical da distribuição espacial, valores representativos da camada inercial situada acima das coberturas, e onde os fluxos já representam um resultado integrado e ponderado dos fluxos reais verificados naquela camada inferior adjacente às superfícies.

Sob a óptica dos estudos que envolvem medições no interior da camada inercial, e comparando diversos tipos de medições em fluxos de calor observados em quatro cidades com ocupações de solo distintas, Grimmond e Oke (1995) aplicam valores de $\mathrm{Q}_{\mathrm{F}}$ em suas análises, que oscilam entre um mínimo de $10 \mathrm{Wm}^{-2}$ e um máximo de $20 \mathrm{Wm}^{-2}$.

Mas estudos de natureza semelhante àqueles realizados por Sue Grimmond e Timothe Oke não têm sido realizados de modo sistemático para as áreas densamente urbanizadas do Estado de São Paulo, e aparentemente tão pouco em outras regiões do Brasil. O conhecimento da distribuição espacial das fontes emissoras de energia é fundamental em estudos mais detalhados no interior da camada de coberturas. Em geral, as áreas sob ocupação residencial, comercial e de vias públicas parecem ser mais facilmente identificadas, do que aquelas no domínio de estabelecimentos industriais. Em parte, talvez, porque haja uma tendência, nas últimas décadas, em descentralizar estes setores através da área metropolitana. Mas como 
indica Azevedo (2001), esta informação ainda não foi suficientemente estudada para se determinar precisamente a distribuição espacial destes estabelecimentos.

Os indicadores do balanço energético do Estado de São Paulo, contabilizados em 1998 pela Secretaria de Minas e Energia do Estado (SMESP), são utilizados por Azevedo (2001) para estimar a energia dissipada pelos processos industriais. Mas, apesar deste balanço envolver um montante de 600 grandes indústrias, e um outro volume de milhares de pequenas indústrias, como o próprio autor comenta, aliado à própria dificuldade inerente aqui mencionada para o estabelecimento de uma bem fundamentada espacialização deste tipo de fonte, também "as perdas de calor nos processos de conversão são desconsideradas, significando que a energia dissipada é subestimada" (AZEVEDO, 2001, Cap. IV).

Não apenas a dificuldade em se determinar a distribuição correta das fontes de calor antrópico, em um determinado território, apresenta obstáculo para o estudo analítico, mas, também, os próprios fatores físicos inerentes às medições.

Tratando-se de estudos que envolvam observações radiativas em ondas longas, que bem ilustram o problema envolvido nesta tese, encontra-se a clássica tentativa em se determinar a distribuição espacial da temperatura superficial, a partir de dados derivados de sensores que permanecem em órbita ao planeta. Neste caso, dois fatores são relevantes, a interferência atmosférica e a determinação adequada da emissividade radiante do alvo, seja pelo desconhecimento da composição material deste alvo, seja pelo desconhecimento in loco de seu real posicionamento no território.

Em um caso típico dos estudos em ambientes urbanos, que envolve a determinação de ilhas urbanas de calor a partir da análise de imagens de satélite, uma situação crítica pode ocorrer quando estes fatores agem em conjunto e no mesmo sentido, e as correções necessárias não são realizadas. Nesta situação, Roth et alii (1989) menciona que podem ser esperados erros de até $2,5{ }^{\circ} \mathrm{C}$ na determinação da distribuição espacial da temperatura em superfície, para localidades distintas no interior da mancha urbana. Quão satisfatório será este erro, se o for, dependerá em grande parte dos propósitos e da profundidade do estudo. 


\subsection{Padronizações}

\subsubsection{PADRÃO ENERGÉTICO}

Voogt e Oke (1997) efetuaram medidas completas, não convencionais, da temperatura das superfícies urbanas para a cidade de Vancouver, sem a utilização das tradicionais estações fixas, e apresentaram seis definições distintas de superfícies urbanas que podem ser analisadas e estudadas em diferentes situações, com diferentes equipamentos ou procedimentos. Os tipos de superfícies já enunciados no item 1.1 são agora enumerados conforme proposto por estes autores:

a) Completa: todas as superfícies são avaliadas (estudos da camada limite atmosférica).

b) Nível do solo (plano zero): apenas as superfícies do solo, externas (incluindo ruas, calçamentos ou áreas cobertas por vegetação) e internas (pisos das edificações) são avaliadas.

c) Nível do topo dos elementos superficiais (caixa preta): apenas as superfícies que constituem os topos ou áreas superiores das edificações são avaliadas.

d) Visão de "olho de pássaro": os topos das edificações, ruas e topo da vegetação são avaliados.

e) Superfície (nível mais próximo à pele humana): superfície aérea, distante cerca de 1,5 m acima do solo (nível aproximado onde são instalados os instrumentos meteorológicos ditos de superfície).

f) Deslocamento do plano zero: como no item b, porém, não sobre o solo, mas sim distante uma determinada altura a partir deste.

Outra forma alternativa de mensuração do campo térmico em área urbana é apresentada por Azevedo e Tarifa (2002), que utilizam minirregistradores para fazerem medições de temperatura e umidade na cidade de São Paulo, com a finalidade de testar um sistema de medições de mais baixo custo, fácil mobilidade e maior autonomia em trabalhos de campo. $\mathrm{O}$ sistema mostrou-se bem adaptável às condições ambientais, e isolado, em termos de incidência de radiação e ventos, fornece valores comparáveis aos obtidos em estações meteorológicas convencionais. As maiores discrepâncias, valores de temperatura em torno de 
$1^{\circ} \mathrm{C}$ ocorreram em alguns dias, entre o fim da tarde e início do período noturno, após um período diurno com ao menos 8 horas de insolação ininterrupta. Discrepâncias como estas tendem a dificultar a observação das diferenças de temperatura do ar dentro e fora de um canyon urbano, tendo em vista que a magnitude destas diferenças é justamente dessa ordem (NAKAMURA e OKE, 1988). No entanto, estas medidas podem ser extremamente relevantes quando comparadas a valores da temperatura das superfícies do canyon, sobretudo em situações cuja disposição geográfica deste se dá na direção norte-sul, e com materiais constituintes das paredes altamente absorvedores de radiação solar. Neste caso, as diferenças entre as temperaturas do ar e das superfícies podem ser elevadas, sendo que tanto o piso como a face norte do canyon pode se tornar uma fonte de calor sensível durante o período noturno (NAKAMURA e OKE, 1988).

Hu et alii (1999) testam aproximações, a fim de agregar informações diversas sobre fluxos e parâmetros de superfícies heterogêneas, para que possam ser aplicados em modelos numéricos de diversas escalas, utilizando como base a equação do balanço de energia sobre uma camada sobrejacente à superfície:

$\mathrm{Q}^{*}+\mathrm{Q}_{\mathrm{F}}=\mathrm{Q}_{\mathrm{H}}+\mathrm{Q}_{\mathrm{E}}+\Delta \mathrm{Q}_{\mathrm{S}}+\Delta \mathrm{Q}_{\mathrm{A}}$

Onde $\mathrm{Q}_{\mathrm{H}}$ é a perda convectiva de calor sensível, $\mathrm{Q}_{\mathrm{E}}$ é a perda convectiva de calor latente e $\Delta \mathrm{Q}_{\mathrm{S}}$ é a variação do fluxo de calor sensível, através da camada superficial, por condução. $\Delta \mathrm{Q}_{\mathrm{A}}$ representa a variação de energia devida à advecção de ar através da camada. $Q_{F}$ corresponde às fontes antropogênicas de calor. $Q^{*}$ representa o ganho de calor por transferência radiativa, sendo uma componente por radiação solar $(\mathrm{K})$ e outra por radiação térmica $(\mathrm{L})$ :

$\mathrm{Q}^{*}=\mathrm{K} \downarrow-\mathrm{K} \uparrow+\mathrm{L} \downarrow-\mathrm{L} \uparrow$

Este estudo mostra-se de grande interesse para análise em áreas urbanas, devido à grande heterogeneidade das superfícies. Neste caso, as variáveis são discretas e tomadas através de uma área relativa. Por exemplo, o fluxo de calor no solo seria obtido por:

$\mathrm{G}^{\mathrm{D}}=\sum \mathrm{a}_{\mathrm{i}} \mathrm{G}_{\mathrm{i}}$

Onde o índice i representa um determinado tipo de cobertura do solo, que ocupa uma certa área $\mathrm{a}_{\mathrm{i}}$ no domínio modelado.

Grimmond e Oke (1995) analisam medidas de fluxo de energia, de verão, tomadas nos subúrbios de quatro cidades norte-americanas, Chicago, Los Angeles, Sacramento e Tucson. 
Eles analisam duas situações distintas, em um primeiro momento apenas para condições de céu claro, e em um segundo momento para todas as condições de céu observadas. É possível notar algumas diferenças interessantes entre elas. Por exemplo, os valores mais elevados de fluxo de calor sensível em Tucson, caracterizando uma superfície mais seca, desértica ou pavimentada. Ou então, o maior total de radiação líquida na superfície para Chicago, na situação de céu claro, inclusive com maiores valores instantâneos no período da tarde. Devido em parte ao fato de haver chovido em Chicago, ocorrendo assim uma diminuição considerável da concentração de material particulado na atmosfera e aumento substancial da radiação solar que atinge a superfície. Isso ao contrário das outras cidades, como Los Angeles, onde havia maior concentração de material particulado favorecido, sobretudo, pela situação de estabilidade atmosférica e pela localização geográfica no vale de São Gabriel.

\subsubsection{PADRÃO DINÂMICO}

Nunez e Oke (1977) tentaram avaliar o impacto dos fluxos de ar na transferência de calor, através de medições realizadas em um canyon urbano de Vancouver. Duas situações distintas são colocadas, uma quando os ventos são paralelos às paredes do canyon, e outra quando eles cruzam o canyon. A primeira mostrou-se mais fácil de ser avaliada e apresentou fluxos maiores de calor para intensidades maiores do vento; para ventos de $01 \mathrm{~ms}^{-1}$ obteve-se um fluxo de energia de $50 \mathrm{Wm}^{-2}$, enquanto que para um vento mais intenso, de $02 \mathrm{~ms}^{-1}$, obteve-se um fluxo de energia de cerca de $170 \mathrm{Wm}^{-2}$. No entanto, a segunda condição, com o vento cruzando o canyon, e induzindo um vórtice vertical no interior deste, mostrou-se também importante, porém de difícil avaliação quantitativa, devido talvez à mistura das propriedades do ar, gerada pelo vórtice, e a não suficiente resolução espacial da distribuição dos instrumentos.

Parâmetros derivados de observações também se mostram como importantes avaliadores dos fenômenos estudados. Um destes parâmetros é o número de Richardson (Ri), que se constitui em uma razão adimensional obtida através da temperatura medida em dois níveis e da velocidade do vento em um dos níveis. Thorsson e Eliasson (2003) exploram também aspectos das circulações de ar dentro da área urbana de Göteborg (Suécia), analisando através de medições com anemômetros sônicos e ultra-sônicos a ocorrência de brisas intra-urbanas de caráter térmico. Estas brisas se formam especialmente no período noturno, sob condições de forte estabilidade termodinâmica do ar próximo à superfície ( Ri > 0). No entanto, em uma 
escala mais reduzida, no interior de um canyon, há uma tendência de manutenção da condição de instabilidade (NAKAMURA e OKE, 1988), ou no máximo uma proximidade à condição de neutralidade, não só durante o dia, como também à noite. Este efeito de microescala pode contribuir para a atenuação das brisas intra-urbanas.

Ainda na escala de um canyon, as circulações atmosféricas geradas em seu interior, a partir de um fluxo acima das coberturas, podem estar em oposição devido à ocorrência de vórtices (NAKAMURA e OKE, 1988), que tendem a ser mais bem definidos tanto quanto o eixo do fluxo externo for mais proximamente ortogonal ao canyon.

França (1946) e Silva Dias e Machado (1997) analisam as circulações de ar na área em que se localiza a RMSP, porém, em uma escala regional ou local, seja abordando os efeitos sobre a bacia de São Paulo, ou vislumbrando os efeitos sobre elementos mais específicos desta bacia, como fundos de vales ou vertentes dos espigões. Silva Dias e Machado (1997) analisam padrões distintos de verão, que originam ou não nevoeiros (MACHADO, 1993), especialmente nos vales utilizando um perfil vertical da topografia na direção SE - NO, com resolução espacial de $4 \mathrm{~km}$. Para tal, aplicam um modelo numérico para verificarem uma possível reprodução das observações realizadas em experimento de campo, capaz de considerar características do solo do domínio estudado e também os processos microfísicos da atmosfera, como as mudanças de estado entre espécies de hidrometeoros presentes na atmosfera (vapor d'água, gotas de nuvem, gotas de chuva, cristais de neve, granizo ou pristina). As simulações numéricas do nevoeiro são iniciadas com uma determinada concentração de material particulado higroscópico, característico de regiões urbanas, e por sondagens de temperatura, umidade e vento da troposfera e obtidas no Aeroporto de Congonhas. As sondagens são de dias distintos, com diferentes condições sinóticas. Uma delas representa um padrão pré-frontal, com forte fluxo de noroeste e que inibe a formação de brisa marítima. A segunda sondagem é de um dia com fluxo de noroeste bem menos intenso e com desenvolvimento vespertino da brisa marítima sobre o planalto paulistano. Neste segundo caso verifica-se a ocorrência de nevoeiro noturno no interior dos vales sobre o planalto, devido em parte à advecção de ar úmido do oceano para o continente. 


\subsubsection{URBANIZAÇÃO}

Para se quantificar as alterações oriundas do impacto da urbanização nos campos térmicos e de circulação de massa, são necessários estudos comparativos entre localidades com diferentes graus de urbanização. Por exemplo, no caso do balanço radiativo, Oliveira et alii(2002c) analisam padrões de radiação solar na superfície, comparando duas localidades, uma urbana (São Paulo) e outra não-urbana (Botucatu). A escolha destas duas localidades é apropriada, pois ambas possuem latitudes e altitudes semelhantes, além de uma caracterização climática relativamente próxima, no que se refere à distribuição das chuvas no decorrer do ano, principalmente. Estudos como estes são muito importantes na análise de padrões urbanos, pois tornariam possível o dimensionamento do impacto dos efeitos da urbanização e da ação antropogênica. Em particular, esse estudo foi motivado pela grande população da RMSP, já em torno de 16,5 milhões de habitantes no início dos anos 90 (KRETZSCHMAR, 1994), que em sua maioria vive sob o impacto das condições ambientais estudadas; a RMSP possui um grande consumo de fontes de energia elétrica e fóssil, que poderia ser substituído, ao menos em parte, por energia solar; as localidades possuem diferenças discrepantes quanto à concentração de material particulado na atmosfera, o que acarreta alterações na radiação incidente em superfície; há disponibilidade de um conjunto de dados observados de radiação de cerca de 10 anos para ser analisado e, além disso, há equipamentos disponíveis para mensuração das taxas de radiação, com precisão e qualidade, inclusive em termos da componente difusa (OLIVEIRA et al., 2002b).

A comparação de dias de céu claro entre São Paulo e Botucatu indica que uma boa correlação pode ser obtida para os termos de onda curta do balanço de energia. Mas para os termos de onda longa o mesmo pode não ocorrer. Sob condições sem obstruções verticais, pode-se notar a influência do conteúdo de vapor de água na atmosfera. Padrões distintos de evolução diurna da pressão de vapor ou da razão de mistura tornam-se, nestas condições, relevantes para a determinação de um padrão diurno para o fluxo em ondas longas. 


\subsection{Características urbanas}

A Região Metropolitana de São Paulo (RMSP) abrangia, já no início dos anos 80, 37 municípios, em uma área de $7.951 \mathrm{~km}^{2}$ (MONTEIRO, 1981). Sendo que no fim dos anos 90, a EMPLASA já mencionava que cerca de um quarto desta área, aproximadamente $2.000 \mathrm{~km}^{2}$ (AZEVEDO, 2001), estava urbanizada.

Entre as décadas de 60 e 80 foram verificdas as suas maiores taxas de crescimento urbano, o qual ainda não cessou, especialmente em termos de ocupação residencial. Naquele período já se observava mais de $1.000 \mathrm{~km}^{2}$ de áreas edificadas, que, segundo Monteiro (1981), cresciam a um ritmo anual de cerca de 120 mil novas residências, "perfazendo uma área total de $75 \%$ e com densidade demográfica de aproximadamente $1.263 \mathrm{hab} . \mathrm{km}^{-2}$ ”. Ao fim deste período de máxima expansão, já eram contabilizados 1,5 milhão de veículos automotores e cerca de 18.000 indústrias (MONTEIRO, 1981). Em meados dos anos 90 já eram totalizados 3,5 milhões de veículos (KRETZSCHMAR, 1994), e este montante tende ainda a crescer. Segundo o Departamento Estadual de Trânsito do Estado de São Paulo (DETRAN - SP) a frota atual já é superior a 6 milhões de veículos. 


\subsubsection{BALANÇOS DE ENERGIA DO SISTEMA GERAL HUMANO- URBANO}

Do ponto de vista do meio físico, o território da RMSP apresenta ocupação muito heterogênea, sendo que uma certa fração é definida a partir deste momento como urbana. A fração urbana da RMSP será tomada, conforme Azevedo (2001), como a área onde reside e por onde circula a maior parte de sua aglomeração humana. A RMSP possui uma área urbanizada de $2.050 \mathrm{~km}^{2}$, estendendo-se através de 31 municípios, e abriga cerca de $96 \%$ de sua população (EMPLASA, 1999 in AZEVEDO, 2001).

O sistema climático, quando abordado como função do ritmo semanal das atividades humanas (AZEVEDO, 2001), torna evidente uma série de padrões que conduzem à perspectiva de uma derivação antrópica, concomitantemente à evolução sazonal das fontes energéticas naturais que alimentam, conduzem e dissipam o desenvolvimento deste sistema.

Os microclimas da RMSP são influenciados em grande parte pela energia dissipada a partir da biomassa humana (AZEVEDO, 2001), sobretudo durante períodos breves e em locais restritos sob domínio de grandes aglomerações humanas, tais como salas de aula, estádios de futebol, templos religiosos e meios de transporte lotados. Em um exemplo extremo, se toda a população humana fosse acomodada no território da RMSP (AZEVEDO, 2001), esta energia dissipada seria equivalente à quantidade anual do fluxo estimado ou observado de radiação solar global ao nível do solo para o mesmo território (TARIFA, 1972 e FUNARI, 1983 in AZEVEDO, 2001; OLIVEIRA et alii, 2002a).

Para manutenção da biomassa humana, Azevedo (2001) estima que cerca de $25.10^{10} \mathrm{MJ}$ são dissipados anualmente. Sendo que para cada Joule dissipado por um ser humano, tem-se aproximadamente 2,5 J liberados pela decomposição dos alimentos que não foram ingeridos, e que ao final do trato digestivo são liberados no solo e em cursos de água da RMSP. Deste novo montante, da ordem de $62,510^{10} \mathrm{MJ}$, cerca de $40 \%$ são liberados fora do território da RMSP.

Este resultado, juntamente com as atividades sócioeconômicas, indica uma influência nos aspectos energéticos que extrapola a área da RMSP, tornando ainda mais complexa a análise climática nos setores definidos como não-urbano dentro ou fora deste domínio. 
Novamente no domínio da RMSP, a energia dissipada pelo uso de fontes energéticas residenciais ocorre fundamentalmente devido ao consumo de gás e energia elétrica (AZEVEDO, 2001). Sendo seu consumo anual estimado em cerca de 7,6 10 ${ }^{10} \mathrm{MJ}$.

O sistema de transportes também contribui para a emissão de energia ao meio urbano, sendo que Azevedo (2001) estima uma dissipação anual em torno de $4210^{10} \mathrm{MJ}$, devido aos veículos automotores à combustão. Portanto, a liberação de energia nas vias de transporte mostra-se superior a cinco vezes do que é dissipado nas quadras residenciais, indicando haver um fluxo preferencial de energia a partir das vias públicas em direção às residências.

Mas as quadras que compõem a malha urbana não são ocupadas apenas por residências, pois lá também verifica-se a ocorrência de setores industriais, públicos, de comércio e de serviços. De uma maneira integrada, e levando em consideração uma tendência na metrópole de escassez das antigas áreas tradicionalmente ocupadas exclusivamente por grandes complexos industriais, e a ascensão de grandes áreas dedicadas ao uso misto, onde prevalece a coexistência de segmentos comerciais, públicos e de pequenas e médias indústrias, tomemos o valor total de energia dissipada que é estimado individualmente por Azevedo (2001) para cada um destes tipos de uso do solo. Neste caso, chega-se a um montante anual de cerca de $45.10^{10} \mathrm{MJ}$, que é muito próximo à quantidade de energia liberada pelo sistema de transportes da RMSP. Ou seja, em termos do clima local, sobrepujando as variações diárias e sazonais, percebe-se uma característica dos fluxos horizontais de energia em uma metrópole, com grande atenuação, ou quase mesmo a nulidade nas trocas de energia entre as vias públicas e as quadras onde a população trabalha. Enquanto, por outro lado, entre as vias públicas e as quadras em que a população reside, parece haver intensa troca de energia, com as ruas e avenidas funcionando como fontes.

Entretanto, para a mesma escala, quando se efetuam comparações entre outros elementos característicos da interface entre a superfície e a atmosfera, sobretudo os meteorológicos, a compreensão climática local (RIBEIRO e AZEVEDO, 2005) pode não ser evidente ou imediata. Uma compreensão equivocada pode emergir se não for considerada, em rigor, a simultaneidade dos registros (AZEVEDO, 2002 b) para estes elementos. Análises exploratórias já confirmam este aspecto para a complexidade climática da RMSP, no caso da precipitação (AZEVEDO, 2001) e dos ventos (AZEVEDO, 2002 a; SILVA DIAS e MACHADO, 1997; MACHADO, 1993). 


\subsubsection{NATURAL E ANTRÓPICO}

Azevedo (2001) ainda observa a energia que é liberada a partir dos resíduos das aglomerações humanas, esmiúça as dificuldades e possibilidades inerentes a sua estimativa a partir das diversas fontes, concluindo em desprezá-las no cômputo anual em comparação àquelas fontes já mencionadas.

Em termos gerais, Azevedo (2001) estima um montante anual para os fluxos de energia dissipada pela população da RMSP, em suas diversas atividades e sob uma perspectiva conservadora, próximo a $12610^{10} \mathrm{MJ}$.

Do ponto de vista da escala climática regional, considerando-se o adensamento de edifícios da área urbana no interior da RMSP, em detrimento das áreas verdes originais (FRANÇA, 1958), bem como a concentração diurna da população na área do núcleo urbano central, Azevedo (2001) demonstra que, em termos anuais, a fonte antrópica de energia corresponde a uma fração que pode variar entre $3 \%$ e $16 \%$ do montante devido à fonte natural de energia, que, por sua vez, se deve fundamentalmente à incidência da radiação solar global. 
2. Análise fundamental 


\subsection{Mensuração cinemática na camada abaixo das coberturas}

\subsubsection{MATERIAL, PROCEDIMENTOS E MÉTODOS}

\subsubsection{O laboratório móvel}

O material utilizado foi adquirido pelo processo FAPESP $n^{\circ}$ 05/56287-0, e corresponde aos seguintes equipamentos:

- 01 Pirgeômetro Eppley Laboratory Inc., modelo PIR (Infrared Precision), sensível à faixa espectral entre $4,0 \mu \mathrm{m}$ e $50,0 \mu \mathrm{m}, \mathrm{n}^{\circ}$ de série $34364 \mathrm{~F} 3$, sensibilidade de $3,72 \mu \mathrm{V} \mathrm{W}^{-1} \mathrm{~m}^{-2}$, ângulo de visão hemisférica e tempo de resposta de 02 segundos.

- 01 Micrologger Campbell Scientific Inc. (CSI), modelo CR3000, no de série 1189, composto de 14 canais e munido de duas baterias ácidas de $9 \mathrm{~V}$ cada e recarregáveis.

- 01 Saldo - radiômetro Kipp e Zonen, modelo NR-LITE, $\mathrm{n}^{\circ}$ de série 052002, sensibilidade de $13,6 \mu \mathrm{V} \mathrm{W}^{-1} \mathrm{~m}^{-2}$, composto por dois sensores posicionados diametralmente em oposição, com campo de visão hemisférico para cada um dos sensores, respectivamente, e uma amplitude de fluxo resultante esperado entre $-200 \mathrm{Wm}^{-2}$ e $1500 \mathrm{Wm}^{-2}$.

- 02 Sensores térmicos infravermelhos Apogee, modelo IRTS precision, sensíveis à faixa espectral entre $6,0 \mu \mathrm{m}$ e $14,0 \mu \mathrm{m}, \mathrm{n}^{\circ}$ de série 2061 e 2065 , respectivamente, ângulo de visão aproximadamente $20^{\circ} \mathrm{e}$ tempo de resposta inferior a 01 segundo.

- 02 Sensores de temperatura RM Young, modelo RTD, originalmente não calibrados, com $\mathrm{n}^{\circ}$ de série S11222 e TS11223, respectivamente, e sensíveis a uma amplitude térmica de $\pm 50^{\circ} \mathrm{C}$.

- Conjunto de 15 termopares CSI, modelo Fine Wire, de 0,003 polegadas, tipo E (cobre e constantan) e n ${ }^{\circ}$ de série 3278 .

O procedimento fundamenta-se na utilização de uma plataforma móvel (Figs. 2.1 e 2.2) montada sobre um veículo motorizado Ford modelo Escort Hobby. 
O veículo é utilizado como um laboratório móvel, composto de um suporte metálico para o saldo-radiômetro, instalado na parte dianteira do móvel (Figs. 2.1a e 2.1b), e uma plataforma instrumental instalada sobre a cobertura do móvel (Fig. 2.2a).

As medições realizadas com o saldo-radiômetro deverão ser corrigidas, devido à presença do anel anti-refratário (Fig. 2.1c), que limita o campo de visão do sensor (Fig. 2.1d).

Esta limitação, apesar de constituir-se em uma correção a ser aplicada às observações, é necessária aos objetivos deste trabalho. Pois, limita a influência radiativa e térmica oriunda dos veículos circundantes no trajeto, especialmente em vias com tráfego excessivo, bem como do próprio móvel utilizado. Além disso, inibe a influência do vento, natural e gerado pelo deslocamento do móvel, sobre o sensor de radiação.

Todos os percursos realizados com a plataforma são georreferenciados pela utilização simultânea de um sistema de geoposicionamento manual GARMIN modelo GPS12.

\subsubsection{Aferição dos sinais observados}

Um procedimento fixo é realizado em área de ocupação específica do solo, com a utilização do conjunto de termopares para avaliação da distribuição em microescala da temperatura superficial.

Alguns termopares podem ser utilizados para medições da temperatura do anel do saldo radiômetro, bem como da temperatura do ar próximo a determinadas superfícies.

Inúmeras comparações e testes têm sido realizados para verificação da sensibilidade dos sensores. São realizadas comparações com valores obtidos regularmente ou em campanhas passadas (MACHADO e AZEVEDO, 2005), tendo sempre em vista ocupações de solo semelhantes. 


\subsubsection{Resolução dos dados adquiridos}

Em termos de deslocamento do laboratório móvel, uma velocidade média de $30 \mathrm{kmh}^{-1}$ é razoável, especialmente na faixa direita das vias públicas. Velocidades maiores põem em prejuízo a resolução espacial de observações que se pretende, enquanto as menores geram conflitos e transtornos aos automóveis que circulam ao redor.

Os dados têm sido amostrados a uma freqüência de $0,5 \mathrm{~Hz}$, e na etapa preliminar armazenados a uma freqüência de um valor médio por minuto. Durante o mês de março de 2007 o intervalo de armazenamento é gradativamente reduzido de 1 minuto, para 30 segundos e posteriormente 20 segundos. A partir do mês de abril de 2007 os dados são armazenados com uma frequiência de 10 segundos.

Em relação à resolução espacial não há possibilidade de um controle exato, pois dependerá fundamentalmente da velocidade que se poderá praticar nas diversas situações encontradas em campo.

Considerando-se uma resolução temporal de 1 minuto para o armazenamento dos dados, e uma velocidade de deslocamento média em torno de $30 \mathrm{~km} \mathrm{~h}^{-1}$, atinge-se uma resolução espacial média de armazenamento em torno de $500 \mathrm{~m}$. Ou em termos de uma resolução temporal de 02 segundos para a amostragem dos dados, e a mesma velocidade de deslocamento, atinge-se uma resolução espacial média de amostragem em torno de $15 \mathrm{~m}$.

Em situações de tráfego mais intenso, mantendo-se as mesmas resoluções temporais, porém com uma velocidade média em torno de $40 \mathrm{~km} \mathrm{~h}^{-1}$, a resolução espacial diminui, obtendo-se para o armazenamento uma resolução em torno de $700 \mathrm{~m}$, e para a amostragem em torno de $20 \mathrm{~m}$.

Mas em situações com tráfego de veículos menos intenso, mantendo-se as mesmas resoluções temporais de armazenamento e amostragem, porém com uma velocidade média em torno de $20 \mathrm{~km} \mathrm{~h}^{-1}$, a resolução espacial aumenta, obtendo-se para o armazenamento uma resolução em torno de $300 \mathrm{~m}$, e para a amostragem em torno de $10 \mathrm{~m}$.

Por outro lado, repetindo-se o raciocínio acima, para uma resolução temporal de 10 segundos, atinge-se uma resolução espacial de armazenamento em torno de $100 \mathrm{~m}$, desenvolvendo-se uma velocidade de $40 \mathrm{~km} \mathrm{~h}^{-1}$, ou para algo em torno de $50 \mathrm{~m}$ se a velocidade for reduzida a $20 \mathrm{~km} \mathrm{~h}^{-1}$. 
Ainda seguindo este raciocínio, se a resolução temporal de armazenamento de dados é ampliada para 10 segundos, pode-se obter a mesma resolução espacial de $500 \mathrm{~m}$ aumentandose a velocidade de $30 \mathrm{~km} \mathrm{~h}^{-1}$ para $180 \mathrm{~km} \mathrm{~h}^{-1}($ !).

É evidente não se pretender desenvolver esta velocidade pelas ruas da cidade de São Paulo, principalmente com a utilização de veículo com mais de uma década de uso ininterrupto. Seria no mínimo um ato de imprudência. Todavia, ressalta-se a possibilidade de se desenvolver um experimento com velocidades maiores sem prejuízo significativo para a resolução espacial dos dados coletados. Isto é útil, sobretudo, em vias expressas como marginais e autovias. 


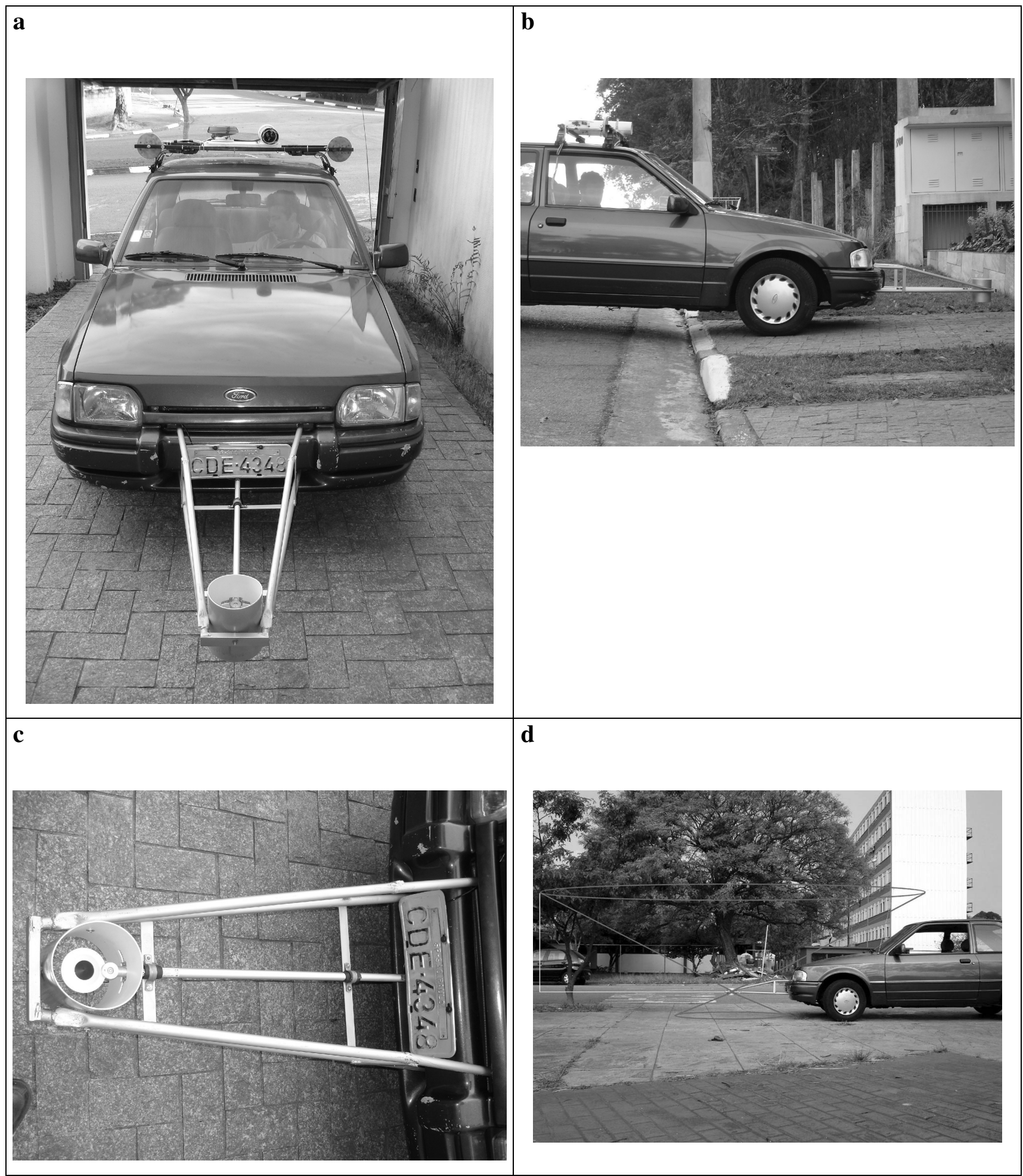

Autor: Tarik Rezende de Azevedo

Figura 2.1 - Laboratório móvel, em perspectiva frontal (a) e lateral (b), saldo - radiômetro com o anel anti refratário (c) e campo de visão (d) gerado pelo dispositivo. 


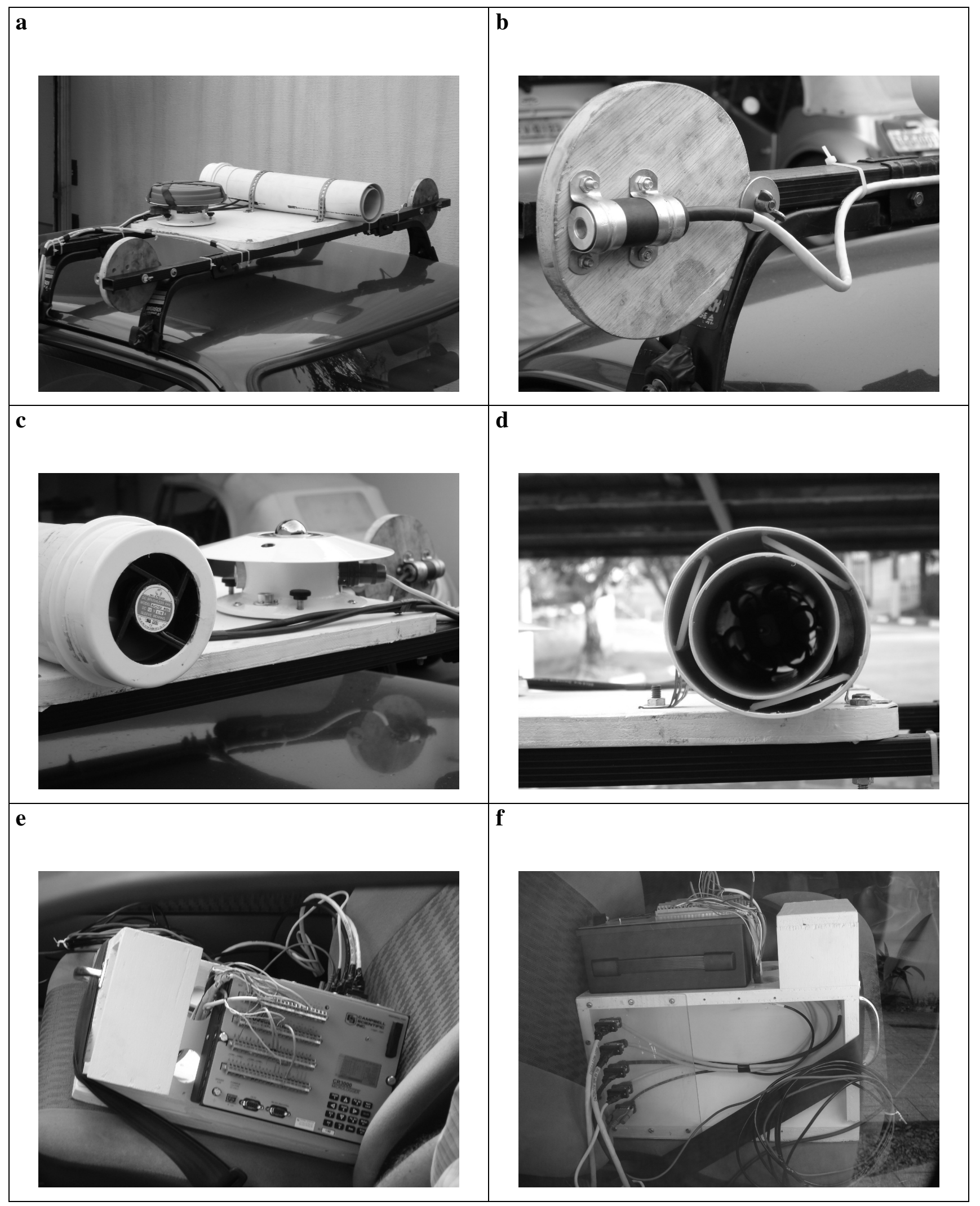

Autor: Tarik Rezende de Azevedo

Figura 2.2 - Plataforma do laboratório móvel (a), sensor IRT fixo em disco giratório (b), pirgeômetro (c), sensor RTD acoplado ao tubo de ventilação (d) e sistema de aquisição de dados em perspectiva frontal (e) e posterior com conectores adaptados (f). 


\subsubsection{O MOSAICO URBANO}

A classificação climática em topoescala é caracterizada por um mosaico paisagístico definido por aquilo que os sensores "vêem" das ruas, por onde o veículo desloca-se. Do mesmo modo que a análise em qualquer escala, fundamentada em observações remotas, independentemente da distância entre o sensor e o alvo, dependerá em grande parte daquilo que o sensor "vê" (SOUX et alii, 2004).

Este mosaico urbano que se configura, é baseado em três matizes mediante a configuração experimental aplicada em campo. A matiz asfáltica (Fig. 2.3 e Tab. 2.1), associada aos alvos para os sensores inferiores de KZ. A matiz celeste (Figs. 2.4 e 2.5, e Tab. 2.2), associada aos alvos para os sensores superiores a KZ. E a matiz vertical (Fig. 2.6 e Tab. 2.3), associada aos alvos para os sensores IRTs.

As matizes apresentadas não representam a completude do alvo, que a rigor corresponderia a uma imagem esférica de $180^{\circ}$. Todavia, representa uma porção angular compreendida por uma abertura aproximada de $60^{\circ}$ a qual confina-se à maior e mais significativa parte do sinal que é observado.

Ressalte-se também que estas matizes não representam a realidade total das ruas na cidade, podendo o leitor simplesmente encontrar feições distintas, com diferentes fatores de visão do céu ou com diferentes elementos compondo as estruturas verticais. No entanto, acredita-se, pela experiência desenvolvida em campo, que estas matizes sucintamente representam as linhas gerais daqueles alvos observados, compondo ao menos alguns traços dos elementos mais significativos que influenciaram a distribuição dos fluxos avaliados.

Esquemas mosaicos distribuem proporcionalmente os fluxos superficiais (PIELKE, 2002, p. 205) sobre terrenos heterogêneos, onde a escala espacial das variações paisagísticas é inferior a algo em torno de 10 ou $5 \mathrm{~km}$. É um procedimento indicado em estudos de modelagem numérica e analítica, em meteorologia e climatologia. Mostra-se especialmente útil neste estudo, no âmbito inferior à mesoescala, para definição de proporções dos elementos relevantes para a camada limite inferior, em cada tipo de ocupação do solo. E útil também para as parametrizações de fluxos na subgrade do domínio. 


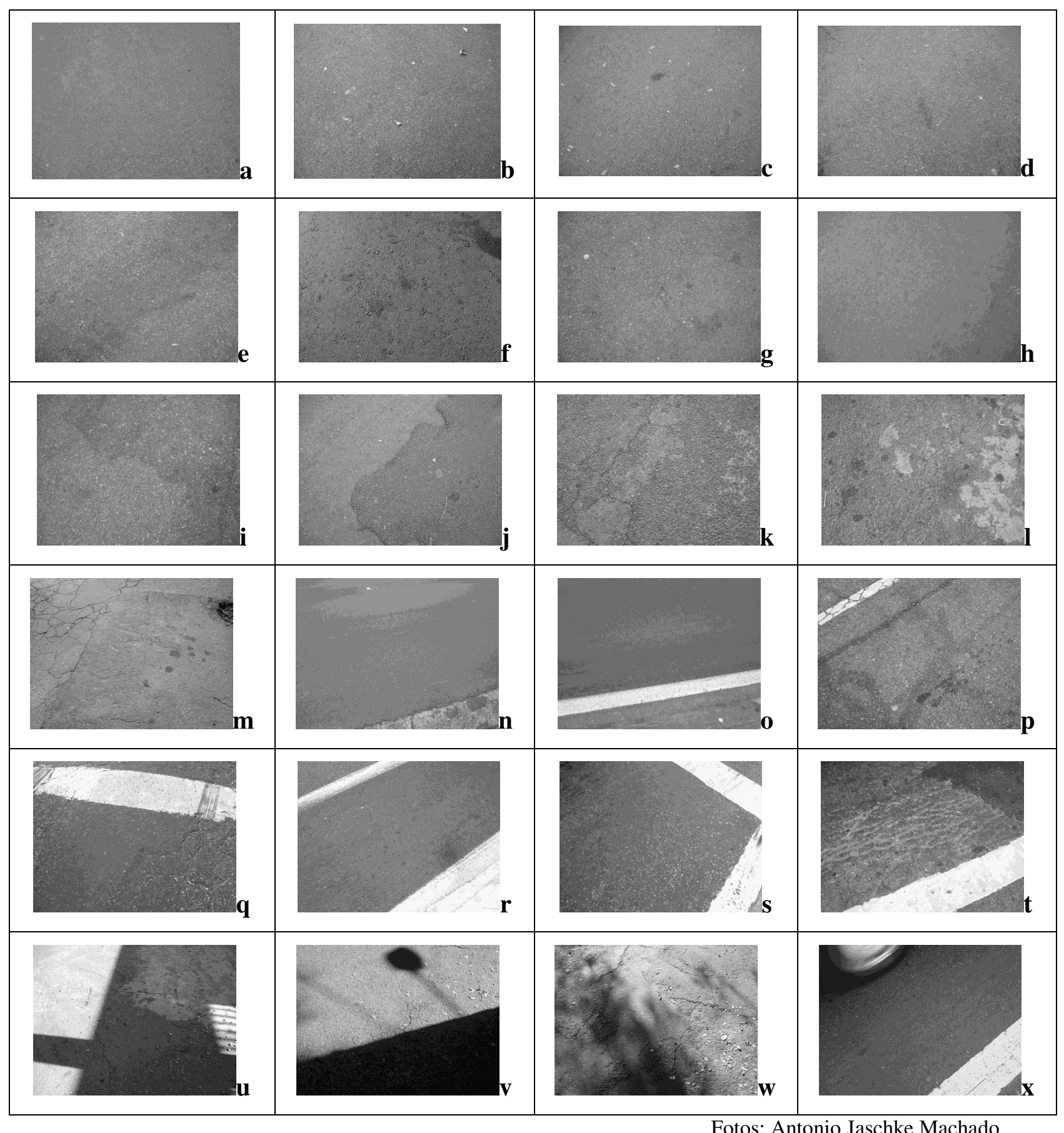

Fotos: Antonio Jaschke Machado

Figura 2.3 - Matiz asfáltica. 1 - homogeneidade (a) a (d). 2 - irregularidades (e) a (h). 3 - de recapeamentos a respingos (i) a (l). 4 - das rachaduras às faixas (m) a (p). 5 - das faixas em asfalto liso às faixas em asfalto altamente irregular, com recapeamentos de diversas idades (q) a (t). 6 - altamente complexos, do sombreado de geometria simples à cena com materiais diversos de elementos dos veículos (u) a (x). 


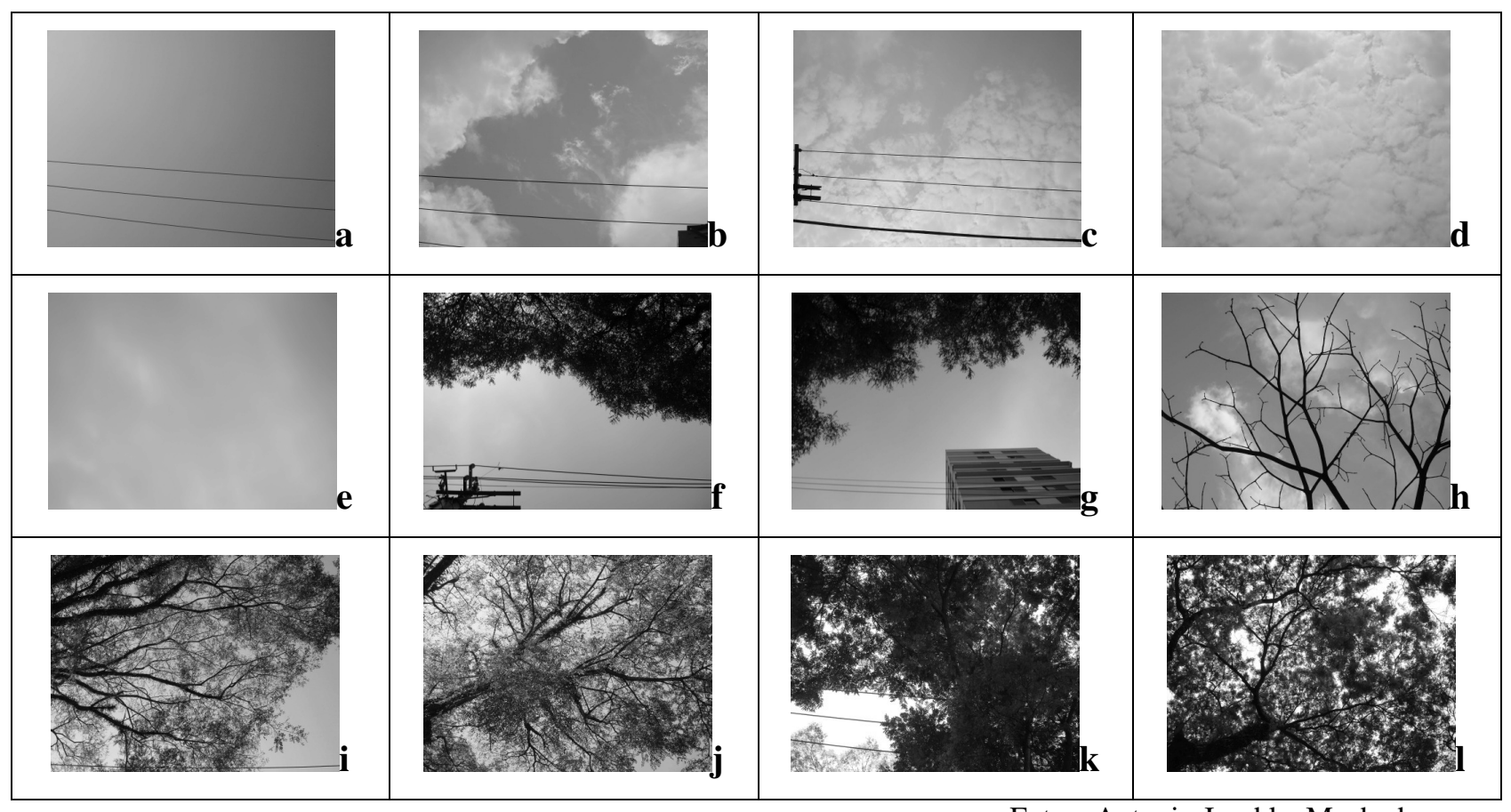

Fotos: Antonio Jaschke Machado

Figura 2.4 - Matiz celeste. 1 - do céu aberto ao nublado com alto-cumulus: (a) a (d). 2 - do totalmente nublado, passando pelas obstruções mistas com árvores e edifícios, às copas desprovidas de folhas: (e) a (h). 3- das copas esparsas às copas densamente foliadas: (i) a (l).

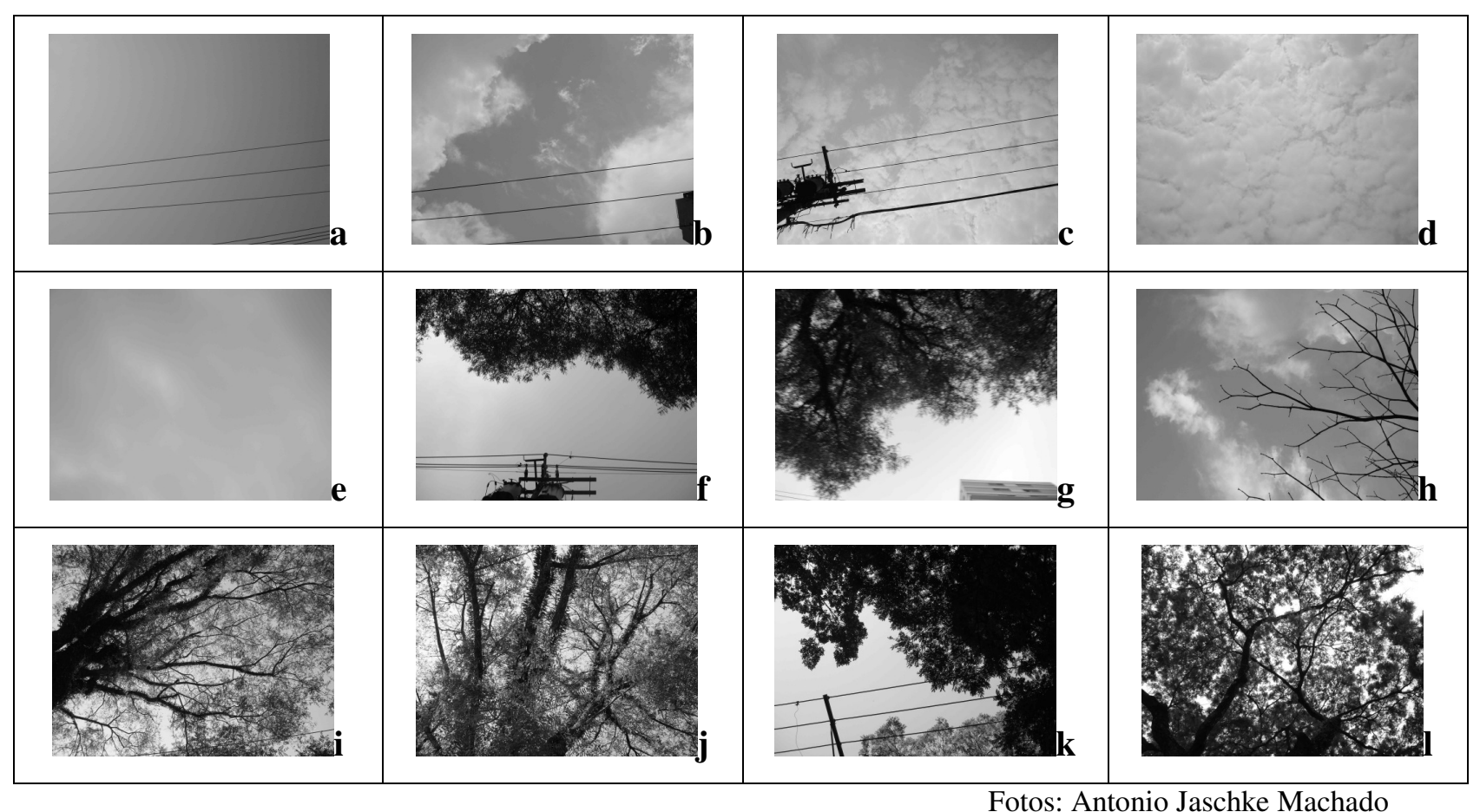

Figura 2.5 - Matiz celeste correspondente à Figura 2.4, observada a partir do nível do pirradiômetro. 


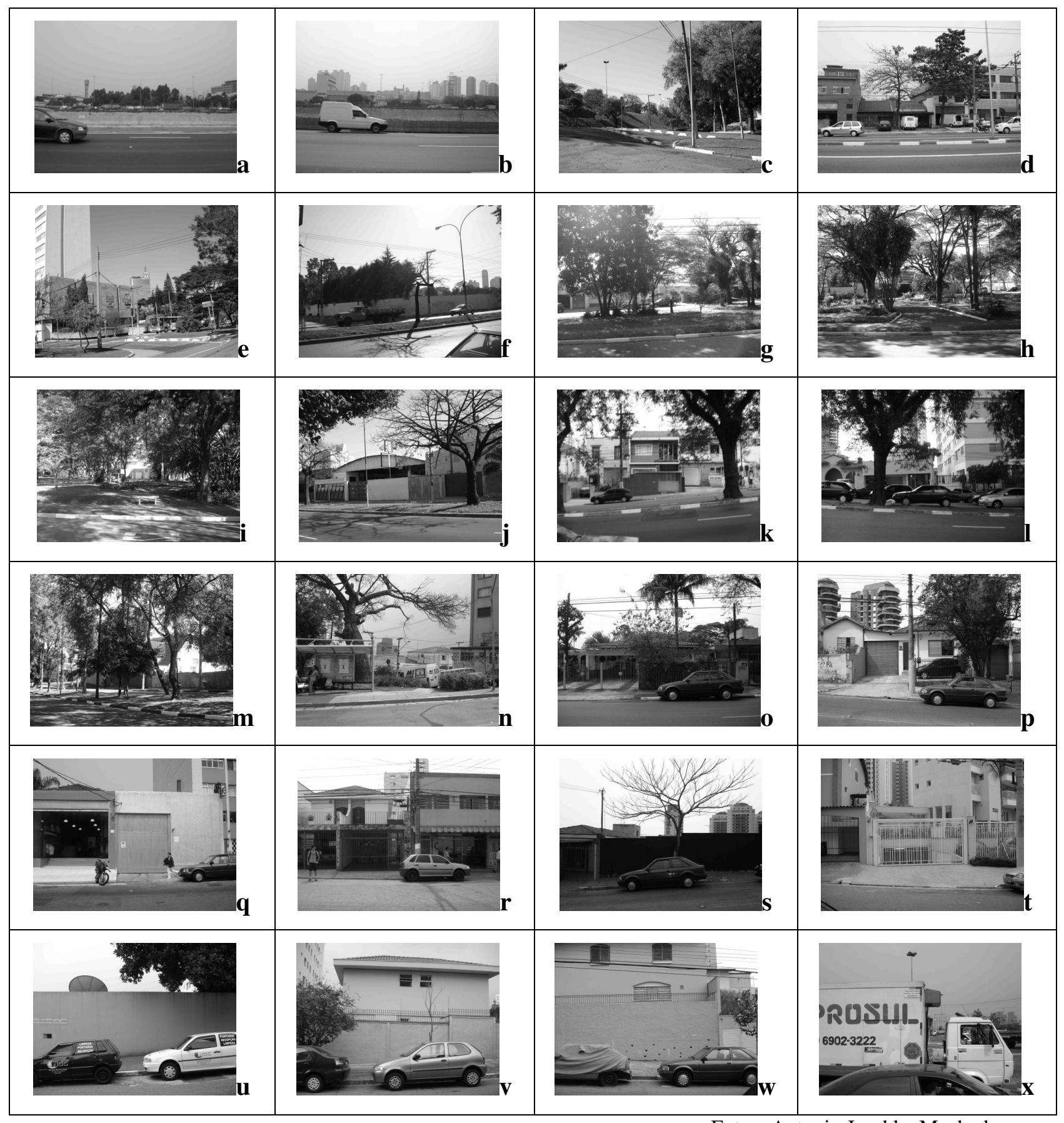

Fotos: Antonio Jaschke Machado

Figura 2.6 - Matiz vertical, do sinal distante, onde a presença térmica do alvo é sobreposta pelo ar circundante, ao sinal próximo, com elevada influência do alvo. 1 - alvos distantes: (a) a (d). 2 - alvos próximos: (e) a (h). 3 das cenas arborizadas às cenas mistas: (i) a (l). 4 - das árvores próximas às paredes próximas: (m) a (p). 5 - das cenas com paredes muito próximas às cenas que contêm exclusivamente paredes, ainda com alguma diversidade de materiais: (q) a (t). 6 - cenas quase homogêneas, das paredes muito próximas e regulares à cena com veículos de grande área lateral parados ou em movimento $(\mathrm{u}) \mathrm{a}(\mathrm{x})$. 
Tabela 2.1 - Máscara para localização relativa à Figura 2.3.

\begin{tabular}{|c|c|c|c|}
\hline $\begin{array}{c}\text { Sebastião Cortez sob } \\
\text { incidência solar }\end{array}$ & $\begin{array}{c}\text { Sebastião Cortez sob a } \\
\text { sombra das árvores }\end{array}$ & pista leste da Pompéia & pista oeste da Pompéia \\
\hline pista oeste da Pio XI & pista norte da Queiroz F & pista norte da Dardanelos & pista leste da Diógenes \\
\hline pista sul da Dardanelos & pista oeste da Diógenes & pista leste da Pio XI & pista única da Tito \\
\hline pista sul da Hermann Jr & $\begin{array}{c}\text { pista sul externa da } \\
\text { Marginal Tietê }\end{array}$ & $\begin{array}{c}\text { pista norte interna da } \\
\text { Marginal Tietê }\end{array}$ & $\begin{array}{c}\text { pista norte da Norma } \\
\text { Gianotti }\end{array}$ \\
\hline pista sul da Norma \\
Gianotti & $\begin{array}{c}\text { pista sul interna da } \\
\text { Marginal Tietê }\end{array}$ & $\begin{array}{c}\text { pista sul da Mq de } S^{\circ} \\
\text { Vicente }\end{array}$ & $\begin{array}{c}\text { pista norte da Mq de } S^{\mathbf{o}} \\
\text { Vicente }\end{array}$ \\
\hline $\begin{array}{c}\text { pista leste da John } \\
\text { Lennon }\end{array}$ & $\begin{array}{c}\text { pista oeste da John } \\
\text { Lennon }\end{array}$ & pista sul da Semaneiros & $\begin{array}{c}\text { pista norte externa da } \\
\text { Marginal Tietê }\end{array}$ \\
\hline
\end{tabular}

Autor: Antonio Jaschke Machado

Tabela 2.2 - Máscara para localização relativa às Figuras 2.4 e 2.5.

\begin{tabular}{|c|c|c|c|}
\hline pista sul da Hermann Jr & pista sul da Dardanelos & $\begin{array}{c}\text { pista norte externa da } \\
\text { Marginal Tietê }\end{array}$ & $\begin{array}{c}\text { pista sul da Mq } \mathrm{Me}^{\mathrm{a}} \mathrm{S}^{\circ} \\
\text { Vicente }\end{array}$ \\
\hline $\begin{array}{c}\text { pista norte interna da } \\
\text { Marginal Tietê }\end{array}$ & $\begin{array}{c}\text { pista norte interna da } \\
\text { Marginal Tietê }\end{array}$ & pista leste da Pompéia & pista oeste da Pio XI \\
\hline $\begin{array}{c}\text { pista oeste da John } \\
\text { Lennon }\end{array}$ & pista sul da Semaneiros & pista sul da Queiroz $\mathrm{F}^{\mathbf{o}}$ & pista leste da Diógenes \\
\hline
\end{tabular}

Autor: Antonio Jaschke Machado

Tabela 2.3 - Máscara para localização relativa à Figura 2.6.

\begin{tabular}{|c|c|c|c|}
\hline $\begin{array}{c}\text { face norte } \\
\text { da Marginal Tietê }\end{array}$ & $\begin{array}{c}\text { face sul } \\
\text { da Marginal Tietê }\end{array}$ & $\begin{array}{c}\text { face oeste } \\
\text { da Semaneiros }\end{array}$ & $\begin{array}{c}\text { face norte } \\
\text { da Norma Gianotti }\end{array}$ \\
\hline $\begin{array}{c}\text { face norte } \\
\text { da Hermann Jr }\end{array}$ & $\begin{array}{c}\text { face sul } \\
\text { da Queiroz } F^{o}\end{array}$ & $\begin{array}{c}\text { face oeste } \\
\text { da John Lennon }\end{array}$ & $\begin{array}{c}\text { face oeste } \\
\text { da John Lennon }\end{array}$ \\
\hline $\begin{array}{c}\text { face leste } \\
\text { da John Lennon }\end{array}$ & $\begin{array}{c}\text { face leste } \\
\text { da Queiroz } F^{o}\end{array}$ & $\begin{array}{c}\text { face oeste } \\
\text { da Pompéia }\end{array}$ & $\begin{array}{c}\text { face leste } \\
\text { da Pompéia }\end{array}$ \\
\hline $\begin{array}{c}\text { face leste } \\
\text { da Semaneiros }\end{array}$ & $\begin{array}{l}\text { face leste } \\
\text { da Pio XI }\end{array}$ & $\begin{array}{c}\text { face leste } \\
\text { da Diógenes }\end{array}$ & $\begin{array}{l}\text { face oeste } \\
\text { da Pio XI }\end{array}$ \\
\hline $\begin{array}{l}\text { face norte } \\
\text { da Tito }\end{array}$ & $\begin{array}{l}\text { face sul } \\
\text { da Tito }\end{array}$ & $\begin{array}{l}\text { face leste } \\
\text { da Pio XI }\end{array}$ & $\begin{array}{c}\text { face norte } \\
\text { da Dardanelos }\end{array}$ \\
\hline $\begin{array}{c}\text { face sul } \\
\text { da Dardanelos }\end{array}$ & $\begin{array}{c}\text { face sul } \\
\text { da Dardanelos }\end{array}$ & $\begin{array}{c}\text { face norte } \\
\text { da Dardanelos }\end{array}$ & 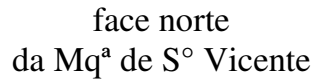 \\
\hline
\end{tabular}

Autor: Antonio Jaschke Machado 


\subsubsection{TRANSETOS E PONTOS DE AMOSTRAGEM}

\subsubsection{Experimento piloto e magnitude do fluxo}

Os experimentos móveis têm como referência inicial um transeto realizado no perímetro da Faculdade de Filosofia, Letras e Ciências Humanas (FFLCH) da Universidade de São Paulo (USP), no Campus da Cidade Universitária Armando Salles de Oliveira (CUASO), localizada no bairro do Butantã da cidade de São Paulo (MACHADO e AZEVEDO, 2005), a partir do qual são identificados os primeiros padrões de referência para a emissão em ondas longas

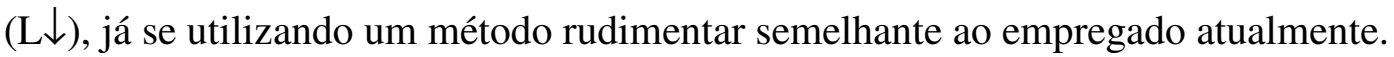

A variabilidade espacial em $L \downarrow$ pode ser analisada através de diversos tipos de ocupação do solo e comparada em magnitude a valores obtidos em outras localidades, sujeitas a variações topográficas muito maiores (IZIOMON et alii, 2003).

A partir deste experimento teste, realizado no início da primavera de 2003, é idealizada uma série de rotas e roteiros a serem experimentados pelo laboratório móvel.

\subsubsection{Domínio espacial e amplitude escalar observada}

Estes roteiros fundamentam-se inicialmente sob a perspectiva da análise escalar (Tab. 2.4) do clima (MONTEIRO, 1975; ORLANSKI, 1976), desde uma escala mais abrangente da RMSP até a perspectiva estritamente localizada do canyon urbano, ou seja, desde a mesoescala $\beta$ até a microescala $\beta$.

Assim sendo, pode-se admitir que os experimentos idealizados e praticados neste trabalho são capazes de representar tanto os fenômenos de microescala $\alpha$, como também aquele de meso escala $\gamma$. Ou seja, encontramo-nos exatamente na fronteira entre dois mundos escalares, que se convenciona denominar o mais reduzido como microescala e o mais amplo de mesoescala.

São planejados quatro conjuntos escalares de roteiros, subdivididos em categorias que ora privilegiam o tipo de ocupação do solo, ora a relevância de fenômenos meteorológicos e ora a analogia com certos deslocamentos históricos sociais através da área compreendida pelo 
limite verde claro da Figura 2.7, que pode bem representar os limites físicos em que o urbano passa a ter suas características mais marcantes atenuadas.

Tabela 2.4 - Representação escalar abrangente da fenomenologia meteorológica e sua relação com os efeitos climáticos urbanos. Em destaque as seguintes concepções: teórica de Orlanski (hachurado sólido), empírica (hachureado sólido e horizontal) e teórica de Monteiro (hachurado sólido, horizontal e diagonal) (modificado após MACHADO e AZEVEDO, 2007a).

\begin{tabular}{|c|c|c|c|c|c|c|}
\hline$>10^{4} \mathrm{~km}$ & $\begin{array}{c}\text { Ondas } \\
\text { de } \\
\text { estabilidade }\end{array}$ & $\begin{array}{l}\text { Ondas } \\
\text { de } \\
\text { maré }\end{array}$ & & & & Macro $\alpha$ \\
\hline $\begin{array}{c}10^{4} \mathrm{~km} \\
2.000 \mathrm{~km}\end{array}$ & & $\begin{array}{l}\text { ondas } \\
\text { baroclínicas }\end{array}$ & & & & Macro $\beta$ \\
\hline $\begin{array}{l}2.000 \mathrm{~km} \\
200 \mathrm{~km}\end{array}$ & & $\begin{array}{l}\text { Frentes } \\
\mathrm{e} \\
\text { furacões }\end{array}$ & & & & Meso $\alpha$ \\
\hline $\begin{array}{l}200 \mathrm{~km} \\
20 \mathrm{~km}\end{array}$ & & & 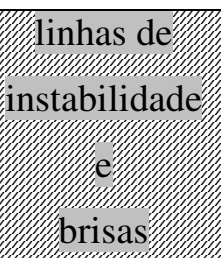 & & & Meso $\beta$ \\
\hline $\begin{array}{l}20 \mathrm{~km} \\
2 \mathrm{~km}\end{array}$ & & & $\begin{array}{r}\text { tempestades } \\
\text { efeitos }\end{array}$ & urbanos & & Meso $\gamma$ \\
\hline $\begin{array}{l}2 \mathrm{~km} \\
200 \mathrm{~m}\end{array}$ & & & $2 \quad$ & 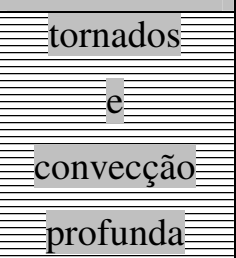 & & Micro $\alpha$ \\
\hline $\begin{array}{l}200 \mathrm{~m} \\
20 \mathrm{~m}\end{array}$ & & & & 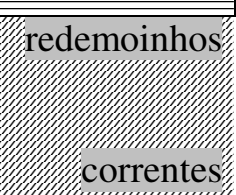 & e & Micro $\beta$ \\
\hline$<20 \mathrm{~m}$ & & & & & $\begin{array}{c}\text { plumas } \\
\text { e } \\
\text { turbulência }\end{array}$ & Micro $\gamma$ \\
\hline & $>1$ mês & mês - dia & dia - hora & hora - min & $\min -\operatorname{seg}$ & \\
\hline
\end{tabular}

Adaptado de Orlanski (1976) 


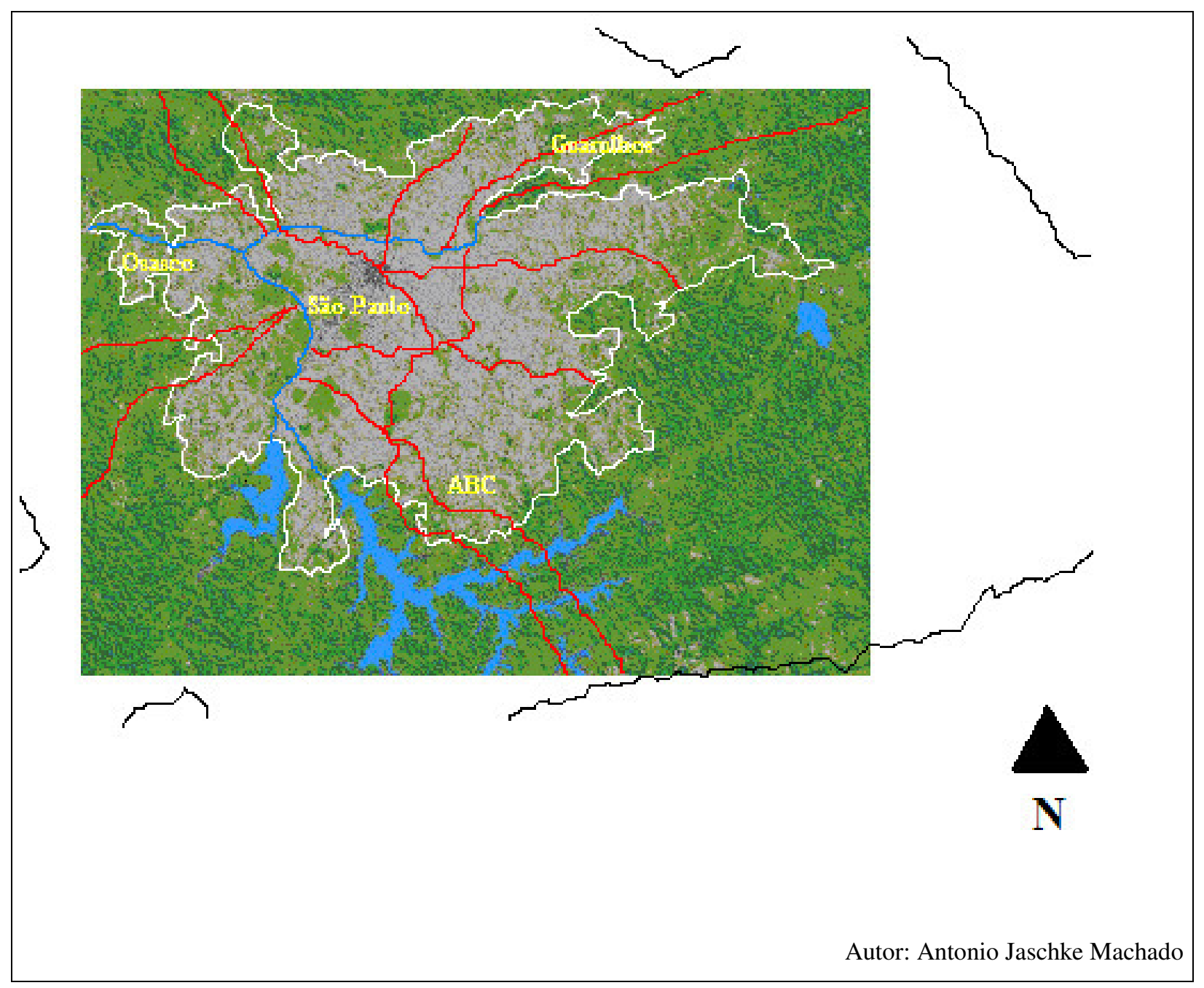

Figura 2.7 - Malha viária que compõe os transetos das escalas 1 e 2 (linhas vermelhas) de amostragem, disposta sobre uma imagem da estimativa de $Q^{*}$ (para os detalhes da obtenção desta imagem classificada ver MACHADO e AZEVEDO, 2006b). O polígono representado pela linha branca corresponde ao limite entre a área da RMSP considerada urbanizada (interior) e a área na qual as características urbanas são atenuadas (exterior), para a escala regional. 


\subsubsection{ESTIMATIVA DE L*}

Após a montagem dos equipamentos (Fig. 2.2) sobre a plataforma e no anel anti-refratário, é realizada uma série de experimentos. Ora fixos em ambiente fechado e sob condições controláveis, ora móveis com exposição ao meio externo e utilizando a configuração do laboratório móvel (Fig. 2.1).

Tendo em vista os objetivos do projeto, é analisado um transeto móvel para verificação da capacidade de detecção de dois efeitos elementares, a ilha atmosférica urbana de calor e a distribuição das temperaturas das paredes (MACHADO e AZEVEDO, 2007a).

Dentre os dados obtidos, merece também destaque o sucesso na aquisição dos fluxos

radiativos. Tanto $\mathrm{L} \downarrow$ como $\mathrm{Q}^{*}$ tem apresentado magnitudes coerentes em relação às encontradas na literatura e compatíveis com a variabilidade de ocupação do solo observada em campo.

\subsubsection{O fluxo $L \uparrow$ noturno}

Para que fosse atingido o objetivo de obtenção do saldo radiativo em ondas longas ( $\left.\mathrm{L}^{*}\right)$, restaria ainda uma especificação necessária para $\mathrm{L} \uparrow$,

$\mathrm{L}^{*}=\mathrm{L} \downarrow-\mathrm{L} \uparrow$

Para o caso noturno, tendo em vista as medições em $Q^{*}$ e $L \downarrow$, esta obtenção é evidente dado que,

$\mathrm{Q}^{*}=\mathrm{L}^{*}$

Ou seja,

$$
\mathrm{L} \uparrow=\mathrm{L} \downarrow-\mathrm{Q}^{*}
$$




\subsubsection{O problema do fluxo $L \uparrow$ diurno}

Mas para o caso diurno este procedimento não é suficiente, pois há que ser considerado ainda o saldo radiativo em ondas curtas $\left(\mathrm{K}^{*}\right)$. Desta maneira, será seguida a modificação da parametrização sugerida por Offerle et alii (2003), apresentada na equação 1.13.

Neste procedimento, a temperatura do ar $\left(\mathrm{T}_{\mathrm{a}}\right)$ e o fluxo recebido em ondas longas ( $\downarrow \downarrow$ ) são observados. A emissividade superficial $\left(\varepsilon_{\mathrm{o}}\right)$ pode ser determinada por levantamentos apresentados na literatura (ARNFIELD, 1982), observando-se que em grande parte dos experimentos realizados a cobertura imediatamente abaixo do sensor é asfáltica.

Restaria então a determinação de $\mathrm{K} \downarrow$. Todavia, se considerarmos o saldo radiativo em ondas curtas, tem-se

$\mathrm{K}^{*}=\mathrm{K} \downarrow-\mathrm{K} \uparrow$

Relações lineares simples (MACHADO e AZEVEDO, 2006b) podem ser utilizadas nestas implementações, sempre a partir de dados coletados abaixo das coberturas superficiais (MACHADO e AZEVEDO, 2005; 2007a), ou seja, no interior da camada das coberturas urbanas (UCL - Urban Canopy Layer).

As imagens obtidas podem ser redefinidas mediante as características de ocupação do solo obtidas indiretamente pela quantificação dos fluxos. E um novo panorama do balanço energético em superfície é visualizado e caracterizado (MACHADO e AZEVEDO, 2006b).

\subsubsection{Reescrevendo a parametrização de Offerle em termos de $K^{*}$}

Além disso, considere-se a componente refletida pela superfície ( $\mathrm{K} \uparrow$ ) expressa em termos das propriedades refletoras $\left(\alpha_{0}\right)$ desta superfície, e obtém-se

$\mathrm{K} \uparrow=\alpha_{\mathrm{o}} \mathrm{K} \downarrow$

Ou ainda, uma maneira alternativa de expressar-se $\mathrm{K}^{*}$,

$\mathrm{K}^{*}=\mathrm{K} \downarrow\left(1-\alpha_{0}\right)$ 
E a parametrização de Offerle et alii (2003) pode ser reescrita,

$\mathrm{L} \uparrow=\varepsilon_{0} \sigma \mathrm{T}_{\mathrm{a}}^{4}+0,08 \mathrm{~K}^{*}+\left(1-\varepsilon_{\mathrm{o}}\right) \mathrm{L} \downarrow$

Ainda considerando-se que,

$\mathrm{Q}^{*}=\mathrm{K}^{*}+\mathrm{L}^{*}$

Substituindo a relação acima na expressão anterior, e desenvolvendo $L^{*}$ em termos das componentes recebida e emitida pela superfície, chega-se a uma nova forma adaptada para a parametrização de Offerle et alii (2003),

$\mathrm{L} \uparrow=1,087 \varepsilon_{\mathrm{o}} \sigma \mathrm{T}_{\mathrm{a}}^{4}+0,087 \mathrm{Q}^{*}+\left(1-1,087 \varepsilon_{\mathrm{o}}\right) \mathrm{L} \downarrow$

Esta última relação parece corroborar para que a estrutura experimental idealizada seja realmente suficiente para a determinação da distribuição do fluxo radiativo em ondas longas. Não apenas em termos da componente recebida, mas também em termos do seu saldo, observando-se que exatamente a temperatura do ar, o saldo radiativo e o fluxo recebido em ondas longas são simultaneamente observados na plataforma móvel. Tornando-se assim dispensável a estimativa conjunta das componentes do fluxo radiativo em ondas curtas.

\subsubsection{OUTRAS INVESTIGAÇÕES CLIMÁTICAS}

Existem dois métodos para se determinar a influência de uma cidade sobre o clima (GEIGER,1950). O mais comum baseia-se na escolha de alguns pontos de observação fixos, no interior e externamente à área ocupada pela cidade, e após o período de alguns anos as séries temporais das variáveis climáticas escolhidas são comparadas. Este procedimento já era reconhecido desde o fim do séc. XIX nas cidades européias.

Em 1929, na cidade de Viena, Áustria, Wilhelm Schmidt (GEIGER, 1950) foi pioneiro no desenvolvimento de um segundo procedimento metodológico. Este procedimento baseava-se na reunião de registros adquiridos em diversos locais através de uma jornada realizada com 
um veículo motorizado. O experimento original de Wilhelm Schmidt fundamentou-se na utilização de um equipamento elétrico para medição da temperatura, que estivesse livre das influências do motor do veículo, e o trajeto realizado deveria ter como chegada o mesmo ponto de partida para que a influência temporal pudesse ser avaliada.

Nas décadas seguintes, medições de umidade, radiação solar, radiação termal e concentração de material particulado foram agregadas ao protótipo inicialmente idealizado por Wilhelm Schmidt em suas medições da temperatura do ar. E conforme as palavras de Geiger (1950), o veículo motorizado foi equipado, tornando-se um "research auto", com as características de um laboratório móvel.

Em linhas gerais, a idéia original do laboratório móvel para estudar especificamente o clima da RMSP provém desde o início da década de 70, a partir do ensaio proposto por Tarifa (1976).

Voogt e Oke (2003) apresentam uma revisão da literatura, sobre como evoluíram, durante a década de 90, os métodos de investigação dos climas urbanos, através da utilização de sensores remotos termais.

Estes métodos passam a destacar a vegetação como elemento importante da camada urbana. As árvores são responsáveis por importantes efeitos de troca de energia em todas as escalas da cidade, especialmente na pequena escala que compreende o canyon urbano (MACHADO e AZEVEDO, 2005).

Deste modo, a área completa $\left(\mathrm{A}_{\mathrm{c}}\right)$, ou total, de uma superfície urbana passa a ser definida como a soma de três áreas distintas: a área exposta do solo $\left(\mathrm{A}_{\mathrm{o}}\right)$, a área das edificações $\left(\mathrm{A}_{\mathrm{e}}\right) \mathrm{e}$ também a área da vegetação $\left(\mathrm{A}_{\mathrm{c}}\right)$.

\subsubsection{PARÂMETROS METEOROLÓGICOS}

Os meteorológicos constituem o único tratado sistemático, que nos chegou da Antigüidade, a respeito daquilo que os gregos denominavam tà metéora (ARISTÓTELES, séc.IV a.C.). Um compêndio de quatro volumes, versando não apenas sobre os fenômenos propriamente atmosféricos (vol. 3), mas também sobre os fenômenos celestes (vol. 1), marítimos (vol. 2) e minerais (vol. 4). 
Apesar da meteorologia moderna ignorar os precursores clássicos responsáveis em primeira instância pela sua própria existência como ciência moderna, curiosamente mantém hoje um forte caráter de agregação de objetos de interesse, que invariavelmente pode abranger desde as feições de um relevo, especulando-se sobre a aeronomia estratosférica, chegando-se até as emanações de compostos químicos por um agrupamento populacional.

A implantação de redes de observação, muitas vezes idealizadas com propósitos de investigação meteorológica, acaba indo muito além dos registros de parâmetros puramente atmosféricos. Sobretudo em ambientes urbanos é comum encontrar equipamentos mensurando concentrações de diversos tipos de gases que constituem o ar da cidade (MACHADO e AZEVEDO, 2007b). 


\subsection{Travessias urbanas e outros experimentos}

Entre 27 de julho de 2006 e 13 de novembro de 2007, em um período, portanto, de 1 ano e 4 meses, foram realizados 49 experimentos, os quais foram compostos por 35 experimentos móveis, 4 experimentos fixos, 4 experimentos fotográficos e 6 experimentos de aferição dos sensores.

A seguir será apresentada uma descrição sumarizada sobre os 35 experimentos móveis (EM), os 4 experimentos fixos (EFX) e os 4 experimentos fotográficos (EFG). 


\subsubsection{OBSERVAÇÕES EM MOVIMENTO}

Machado e Azevedo (2006a) discutem e demonstram algumas particularidades das medições realizadas sobre plataforma móvel. Em especial no que diz respeito às correções para as observações de L utilizando-se pirgeômetros.

Atualmente, as possibilidades são muito mais amplas, mediante a existência de diversos equipamentos e sensores desenvolvidos no decorrer do século XX. No caso da utilização do pirgeômetro sobre plataformas móveis, há inclusive vantagens representadas pela ventilação oriunda do deslocamento do veículo que proporciona um estado de equilíbrio térmico ao corpo do aparelho. Sendo, assim, desnecessária a aplicação de correções, sobretudo em experimentos diurnos devido ao efeito do aquecimento por incidência de radiação solar, em etapas posteriores à coleta dos dados (MACHADO e AZEVEDO, 2006a).

As fichas dos experimentos em movimento são apresentadas no Anexo 2. Para sua adeqüada compreensão, note-se nas figuras contidas nas fichas, as setas como indicação da direção do movimento e do sentido de deslocamento. O círculo represernta o ponto inicial e/ou final do percurso.

\subsubsection{OBSERVAÇÕES ESTÁTICAS}

As fichas dos experimentos estáticos também são apresentadas no Anexo 2, após os experimentos móveis. 


\subsection{Dimensão temporal dos dados}

\subsubsection{RITMOS E DURAÇÕES}

\subsubsection{Simultaneidade dos fluxos energéticos natural e antrópico}

Dois ritmos e suas respectivas durações são verificados em relação ao conjunto de experimentos móveis. $\mathrm{O}$ ritmo semanal, cuja freqüência está associada às atividades humanas na metrópole, e sua duração dependem diretamente da ocorrência de dias úteis e feriados (Tab. 4.1). Já o ritmo horário, cuja freqüência está associada à posição do disco solar em relação ao horizonte, e sua duração dependem precisamente do intervalo no qual é realizado o experimento (Tab. 4.2).

Tabela 4.1 - Frequiência temporal dos experimentos realizados, em relação ao dia da semana, às atividades humanas e aos períodos horários.

\begin{tabular}{|c|c|c|c|c|c|c|c|c|}
\hline $\begin{array}{c}\text { Dia da } \\
\text { semana }\end{array}$ & $\begin{array}{l}\text { Freq. } \\
\text { geral }\end{array}$ & $\begin{array}{c}\text { Freq. } \\
\text { útil }\end{array}$ & $\begin{array}{l}\text { Freq. } \\
\text { emenda }\end{array}$ & $\begin{array}{l}\text { Freq. } \\
\text { feriado }\end{array}$ & $1 \mathrm{~h} \mathrm{a} 9 \mathrm{~h}$ & $9 \mathrm{~h}$ a $13 \mathrm{~h}$ & $13 \mathrm{~h}$ a $17 \mathrm{~h}$ & $17 \mathrm{~h} \mathrm{a} 1 \mathrm{~h}$ \\
\hline Domingo & 5 & & & 5 & 3 & 1 & 1 & \\
\hline Segunda & 2 & 2 & & & 2 & & & \\
\hline Terça & 5 & 4 & & 1 & & 2 & 2 & 1 \\
\hline Quarta & 6 & 6 & & & 1 & & 3 & 2 \\
\hline Quinta & 6 & 5 & & 1 & 1 & 2 & 2 & 1 \\
\hline Sexta & 6 & 5 & 1 & & & 3 & 1 & 2 \\
\hline Sábado & 5 & 4 & 1 & & 3 & 2 & & \\
\hline Total & 35 & 26 & 2 & 7 & 10 & 10 & 9 & 6 \\
\hline
\end{tabular}


Tabela 4.2 - Representação temporal dos experimentos realizados, em relação ao dia da semana, aos instantes de saída e chegada do laboratório móvel e à distância percorrida durante cada travessia.

\begin{tabular}{|c|c|c|c|}
\hline Dia da semana & Saída & Chegada & Distância (km) \\
\hline Domingo & $6 \mathrm{~h} 20 \mathrm{~min}$ & 8 h 20 min & 49 \\
\hline Domingo & $12 \mathrm{~h} 35 \mathrm{~min}$ & $15 \mathrm{~h} 20 \mathrm{~min}$ & 120 \\
\hline Domingo & $6 \mathrm{~h} 25 \mathrm{~min}$ & 8 h 59 min & 85 \\
\hline Domingo & $9 \mathrm{~h} 45 \mathrm{~min}$ & $12 \mathrm{~h} 10 \mathrm{~min}$ & 96 \\
\hline Domingo & $7 \mathrm{~h} 02 \mathrm{~min}$ & $10 \mathrm{~h} 33 \mathrm{~min}$ & 135 \\
\hline Segunda & $6 \mathrm{~h} 33 \mathrm{~min}$ & 9 h 36 min & 68 \\
\hline Segunda & 5 h $56 \mathrm{~min}$ & $9 \mathrm{~h} 13 \mathrm{~min}$ & 117 \\
\hline Terça & $12 \mathrm{~h}$ & $13 \mathrm{~h} 50 \mathrm{~min}$ & 70 \\
\hline Terça & $15 \mathrm{~h} 01 \mathrm{~min}$ & 17 h $30 \mathrm{~min}$ & 29 \\
\hline Terça & 14 h 53 min & $18 \mathrm{~h} 10 \mathrm{~min}$ & 51 \\
\hline Terça & $17 \mathrm{~h} 07 \mathrm{~min}$ & $19 \mathrm{~h} 16 \mathrm{~min}$ & 43 \\
\hline Terça & 8 h $12 \mathrm{~min}$ & $12 \mathrm{~h} 02 \mathrm{~min}$ & 92 \\
\hline Quarta & $5 \mathrm{~h} 50 \mathrm{~min}$ & $9 \mathrm{~h} 40 \mathrm{~min}$ & 99 \\
\hline Quarta & $15 \mathrm{~h} 40 \mathrm{~min}$ & 16 h $50 \mathrm{~min}$ & 16 \\
\hline Quarta & $17 \mathrm{~h} 02 \mathrm{~min}$ & $20 \mathrm{~h} 32 \mathrm{~min}$ & 71 \\
\hline Quarta & $20 \mathrm{~h} 10 \mathrm{~min}$ & $21 \mathrm{~h} 57 \mathrm{~min}$ & 43 \\
\hline Quarta & $15 \mathrm{~h} 31 \mathrm{~min}$ & 17 h $29 \mathrm{~min}$ & 37 \\
\hline Quarta & $14 \mathrm{~h} 46 \mathrm{~min}$ & $18 \mathrm{~h} 05 \mathrm{~min}$ & 99 \\
\hline Quinta & $16 \mathrm{~h} 30 \mathrm{~min}$ & $17 \mathrm{~h}$ & 6 \\
\hline Quinta & $5 \mathrm{~h}$ & $7 \mathrm{~h} 50 \mathrm{~min}$ & 61 \\
\hline Quinta & $16 \mathrm{~h} 40 \mathrm{~min}$ & $19 \mathrm{~h} 40 \mathrm{~min}$ & 73 \\
\hline Quinta & $13 \mathrm{~h} 30 \mathrm{~min}$ & $16 \mathrm{~h} 20 \mathrm{~min}$ & 21 \\
\hline Quinta & $10 \mathrm{~h} 50 \mathrm{~min}$ & $12 \mathrm{~h} 30 \mathrm{~min}$ & 29 \\
\hline Quinta & $10 \mathrm{~h} 19 \mathrm{~min}$ & $16 \mathrm{~h} 8 \mathrm{~min}$ & 85 \\
\hline Sexta & $9 \mathrm{~h} 20 \mathrm{~min}$ & $11 \mathrm{~h}$ & 10 \\
\hline Sexta & $9 \mathrm{~h} 10 \mathrm{~min}$ & $12 \mathrm{~h} 50 \mathrm{~min}$ & 48 \\
\hline
\end{tabular}


Tabela 4.2 - Continuação.

\begin{tabular}{|c|c|c|c|}
\hline Sexta & $9 \mathrm{~h} 10 \mathrm{~min}$ & $16 \mathrm{~h}$ & 56 \\
\hline Sexta & $16 \mathrm{~h} 50 \mathrm{~min}$ & $18 \mathrm{~h} 10 \mathrm{~min} 20 \mathrm{~min}$ & 33 \\
\hline Sexta & $17 \mathrm{~h} 10 \mathrm{~min}$ & $16 \mathrm{~h} 40 \mathrm{~min}$ & 86 \\
\hline Sexta & $14 \mathrm{~h} 30 \mathrm{~min}$ & $8 \mathrm{~h}$ & 71 \\
\hline Sábado & $4 \mathrm{~h} 50 \mathrm{~min}$ & $9 \mathrm{~h} 15 \mathrm{~min}$ & 103 \\
\hline Sábado & $6 \mathrm{~h} 35 \mathrm{~min}$ & $12 \mathrm{~h} 18 \mathrm{~min}$ & $8 \mathrm{~h} 38 \mathrm{~min}$ \\
\hline Sábado & $10 \mathrm{~h}$ & $13 \mathrm{~h} 50 \mathrm{~min}$ & 121 \\
\hline Sábado & $6 \mathrm{~h} 34 \mathrm{~min}$ & & 2216 \\
\hline Sábado & $9 \mathrm{~h} 37 \mathrm{~min}$ & & \\
\hline Total & & & \\
\hline
\end{tabular}

Autor: Antonio Jaschke Mahado

\subsubsection{Efeito das atividades humanas}

Apesar da maior frequiência de experimentos realizados em dias úteis, especialmente entre quinta e sexta-feira, também são realizados experimentos em domingos e feriados. Isto possibilita investigar padrões que podem estar relacionados com o ritmo das atividades humanas na metrópole.

\subsubsection{Efeitos do meio urbano}

O pensamento geográfico vivencia um amplo processo de renovação (MORAES, 2002). Em termos da climatologia urbana os métodos teledetectivos não representam uma novidade, sendo utilizados, desde a década de 80 , sensores orbitais para estimativas dos padrões de ilha de calor em superfície. Como também não representa uma novidade, a utilização de séries temporais de variáveis meteorológicas para descrever o clima da atmosfera sobre a superfície.

O que parece colocar-se como renovação e desafio, trata-se da utilização de plataformas móveis sobre a superfície e a análise indireta das configurações observadas. Dotadas de 
sensores de teledetecção, em geral termômetros e radiômetros sensíveis à banda termal (entre 8 e $14 \mu \mathrm{m})$ do infravermelho, estas plataformas são capazes de fornecer um interessante panorama reflexivo sobre a simultaneidade, no espaço e no tempo, dos processos térmicos, que, sob quaisquer argumentos racionais, não deveria ser imediatamente descartado.

A variabilidade temporal e espacial da temperatura em uma superfície urbana, na atmosfera adjacente a ela, e, conseqüentemente, do efeito de ilha de calor é resultado de uma complexa troca de fluxos de energia no interior de um volume que contém esta superfície. Em relação à investigação dos efeitos do meio sobre a população, privilegia-se o período em torno do amanhecer, também com maior freqüência de experimentos. A expectativa é evidenciar não apenas o efeito de ilha quente na metrópole, mas também a possível ocorrência do efeito de ilha fria. Os fluxos são em geral representados através de uma relação de balanço (OFFERLE et alii 2006) entre fontes e sumidouros de energia,

$Q^{*}+Q_{F}=Q_{H}+Q_{E}+\Delta Q_{S}+\Delta Q_{A}+S$

Os fluxos $\mathrm{Q}_{\mathrm{F}}$ e $\mathrm{Q}^{*}$ representam, respectivamente, as fontes de energia antrópicas e naturais. As fontes naturais são derivadas do saldo dos processos radiativos originários da energia solar e da emissão atmosférica. No entanto é complexa a determinação, especialmente no caso dos fluxos radiativos em ondas longas, da parcela antrópica e da parcela natural mediante ao que é observado. Durante o período noturno, $Q^{*}$ pode tornar-se um sumidouro de energia, em situações nas quais o fluxo em ondas longas provenientes da superfície para a atmosfera é superior ao fluxo observado a partir da atmosfera.

Os fluxos $\mathrm{Q}_{\mathrm{H}}$ e $\mathrm{Q}_{\mathrm{E}}$ representam as trocas turbulentas de energia, por convecção entre a superfície e o ar, sendo definidos, respectivamente, por uma componente de calor sensível e outra de calor latente.

A partir da definição de um volume que envolve a interface entre superfície e atmosfera (OKE, 1988), o termo $\Delta \mathrm{Q}_{\mathrm{S}}$ indica a variação da energia armazenada no volume, principalmente associada a perdas de energia por condução. Enquanto $\Delta \mathrm{Q}_{\mathrm{A}}$ representa a variação de energia advectada pelas circulações de ar, a partir de localidades com diferentes características térmicas. 


\subsubsection{VALIDAÇÃO}

\subsubsection{Inércia térmica}

Conforme a definição de Timothe R. Oke "o clima de animais representa um dos sistemas climáticos mais complexos, porque eles são capazes de deslocarem-se de um ambiente a outro e carregarem com eles seu próprio suprimento de energia " (OKE, 1987, p. 77).

Estes sistemas são fortemente determinados pelas trocas de energia que se estabelecem entre o indivíduo e seu meio (Fig. 4.1). Em relação aos seres humanos, as diferenças fisiológicas associadas à postura ereta definem o modo específico pelo qual estas trocas estabelecem-se.

As trocas de energia estão em geral associadas a uma direção preferencial, através da qual ocorre o fluxo de energia entre a superfície corpórea e o ar circundante, ou a superfície de contato.

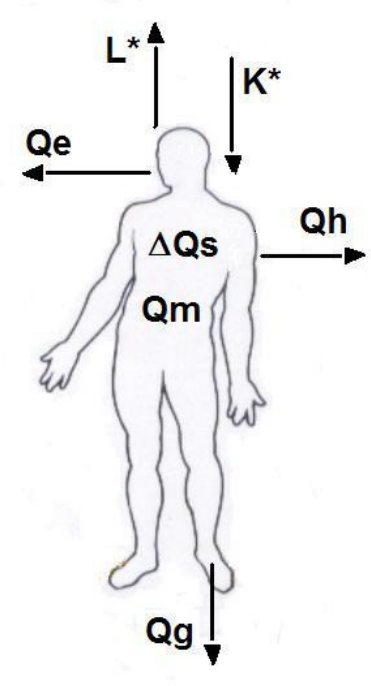

Figura 4.1 - Fluxos envolvidos na troca de energia entre um ser humano e seu ambiente (adaptado para o caso do corpo humano, a partir de OKE, 1987, pag. 191) 
Os fluxos são divididos em duas categorias, os provenientes das fontes de energia e os dissipadores de energia. Existem duas fontes principais de energia para o ser humano: uma externa, associada à absorção da radiação solar $\left(\mathrm{K}^{*}\right)$, sobretudo na faixa das ondas curtas, e uma segunda fonte, porém interna, associada à produção de calor pelos processos metabólicos $\left(\mathrm{Q}_{\mathrm{M}}\right)$.

Em termos dos fluxos associados às perdas de energia pelo corpo humano têm-se: a transferência por condução de calor sensível entre as superfícies sólidas de contato $\left(\mathrm{Q}_{\mathrm{G}}\right)$, as transferências por convecção de calor sensível $\left(\mathrm{Q}_{\mathrm{H}}\right)$ e latente $\left(\mathrm{Q}_{\mathrm{E}}\right)$ entre o corpo e o ar circundante, e a transferência radiativa em ondas longas $\left(\mathrm{L}^{*}\right)$ entre o corpo e o meio através dos fluxos na faixa do infravermelho termal.

Dentre os fluxos de energia apresentados para o modelo proposto (OKE, 1987), K* e L* apresentam o maior impacto imediato para um indivíduo que se desloca por um ambiente complexo. Em geral, estes fluxos são também representados através de sua resultante espectral $\left(Q^{*}\right)$, que equivale ao saldo radiativo total entre estas duas componentes principais.

Para a análise deste impacto, um dos ambientes mais apropriados é o urbano (RIBEIRO e AZEVEDO, 2005), pois ele é composto por uma distribuição muito variada de tipos de ocupação do solo. Além disso, é atualmente o ambiente onde se desenvolve a maior parte das atividades humanas (AZEVEDO, 2001).

A análise da distribuição dos fluxos radiativos em uma cidade pode ser realizada remotamente através de dados obtidos em plataformas orbitais, e preferencialmente combinados com observações realizadas em superfície (Capítulo 3.1, item 3; MACHADO e AZEVEDO, 2006b).

Todavia, seria muito complexa a verificação individual dos fluxos radiativos para cada transeunte que se desloca pelas ruas. Por isso, seria recomendável inicialmente a análise da variabilidade dos fluxos $\mathrm{K}^{*}$ e $\mathrm{L}^{*}$ através de um método que percorra os distintos tipos de ocupação do solo que compõem a superfície da cidade, e que representam o conjunto de variações a que serão submetidos estes indivíduos.

O método escolhido foi, então, o de transversos móveis, utilizando-se equipamentos instalados sobre um veículo que se desloca pela área de estudo (VOOGT e OKE, 1998b). 
Este método foi adaptado para experimentos na cidade de São Paulo, e já apresenta alguns resultados interessantes associados à análise de alguns efeitos climáticos urbanos (MACHADO e AZEVEDO, 2007a), como ilhas de calor, por exemplo, (LOMBARDO,1985).

Todavia, uma questão central e de extrema importância neste caso está associada ao efeito que o veículo teria sobre os padrões observados pelo sensor. Afinal, o motor de um veículo em funcionamento dissipa parte de sua energia através de ondas longas (AZEVEDO, 2001). E um sensor nele instalado, que fosse sensível aos padrões ambientais de $\mathrm{L}^{*}$, poderia estar sujeito à interferência de uma componente indesejável emitida pelo motor, sobretudo considerando sua posição de fixação relativa ao veículo utilizado.

Portanto, o objetivo principal deste estudo é validar um procedimento experimental para observação dos fluxos radiativos em uma área densamente povoada, que represente de uma forma mais próxima possível o efeito sentido pelos indivíduos que se deslocam através desta área e que, principalmente, esteja livre das interferências diretas do próprio sistema experimental de observação.

\subsubsection{Ser humano}

O estado térmico de um indivíduo é definido pelo balanço entre os diversos fluxos de energia (Fig. 4.1) que incidem e emanam de seu corpo:

$Q^{*}{ }_{H B}+Q_{M}=Q_{H}+Q_{E}+Q_{G}+\Delta Q_{S}$

Sendo $Q^{*}{ }_{\text {HB }}$ o saldo resultante entre os diversos fluxos radiativos sobre a superfície corpórea de um indivíduo. Estes fluxos são em geral reunidos em duas categorias, os fluxos radiativos de onda curta $\left(\mathrm{K}^{*}\right)$ e os fluxos radiativos de onda longa $\left(\mathrm{L}^{*}\right)$, representados também em dois sentidos (Figura 4.1), quando atingem o corpo ( $\mathrm{K} \downarrow$ e $L \downarrow$ ) provenientes da atmosfera ou de outras superfícies ao redor do indivíduo, ou quando emanam do próprio corpo ( $\mathrm{K} \uparrow$ e $\mathrm{L} \uparrow$ ):

$Q^{*}{ }_{H B}=(K \downarrow-K \uparrow)+(L \downarrow-L \uparrow)$

O fluxo $\mathrm{K} \uparrow$ depende fundamentalmente do albedo do indivíduo, ou seja, a capacidade da pele e das vestimentas do indivíduo em refletir a luz solar. Enquanto o fluxo L $\uparrow$, depende da 
emissividade da pele e das vestimentas, além da temperatura superficial corpórea do indivíduo, conforme a lei de Stefan-Boltzmann.

Em termos de uma primeira aproximação, que viabilize um método sistemático de observação, assume-se que o fluxo $\mathrm{Q}^{*}{ }_{\mathrm{HB}}$ apresente uma magnitude aproximadamente igual àquela verificada para o fluxo $\mathrm{Q}^{*}$. Como conseqüência desta aproximação, despreza-se a especificidade de albedos e emissividades individuais que possam ser encontrados nas diversas vestimentas utilizadas, e considera-se que o valor médio destes parâmetros não extrapola significativamente a variação encontrada para os diversos elementos que constituem a superfície urbana.

Além disso, assume-se uma situação de curtíssimo prazo, que decorre a partir da resposta ao equilíbrio térmico entre a temperatura da superfície corpórea e a temperatura do ambiente (constituído pela superfície urbana e o ar que o preenche), até a consolidação da resposta termo reguladora do corpo do indivíduo. Este efeito será menos significativo, em relação à aproximação assumida acima, para indivíduos que se deslocam pela cidade.

\subsubsection{Dispositivo}

A introdução do problema da validação de um modelo, em relação à dimensão temporal dos dados que dão origem a este modelo, apresenta os seguintes aspectos complicadores em comparação com as mensurações cinemáticas no Capítulo 1.2.

O método baseia-se na observação do saldo radiativo $\left(\mathrm{Q}^{*}\right)$ na direção ortogonal ao piso das ruas, através da utilização de um pi radiômetro Kipp-Zonen (KZ) acoplado à dianteira de um veículo automotor (Fig. 4.2) Ford, modelo Escort Hobby. Há um anel de PVC branco ao redor do sensor, que obstrui a interferência da emissão por ondas longas originárias no motor quando o veículo encontra-se em funcionamento. Este anel obstrui uma faixa de $30^{\circ} \mathrm{em}$ torno do plano de deslocamento, tanto acima quanto abaixo. Eventuais efeitos desta obstrução podem ser desprezados, em virtude da orientação do sensor e por considerar-se que as superfícies emissoras e irradiantes apresentam um padrão aproximadamente Lambertiano. Estimativas dos valores máximos e mínimos observados de L $\downarrow$, comparando-se os valores obtidos com o dispositivo proposto e com um pirgeômetro, validam esta aproximação (Fig.4.3a). 
A eficácia do anel de PVC é validada através de um extenso conjunto de observações realizadas nas ruas da região metropolitana de São Paulo (RMSP).

Nestes experimentos, um dos aspectos que se busca verificar, é a ocorrência de equilíbrio térmico entre o anel e o ar quando o conjunto desloca-se, através do acoplamento de um termopar na face interior do anel. Nesta situação induz-se artificialmente ventilação sobre o sistema de observação.

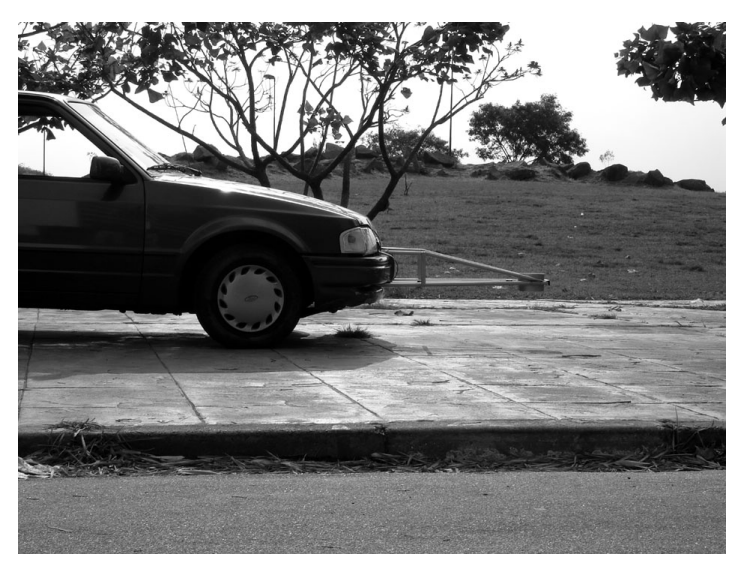

$\mathbf{a}$

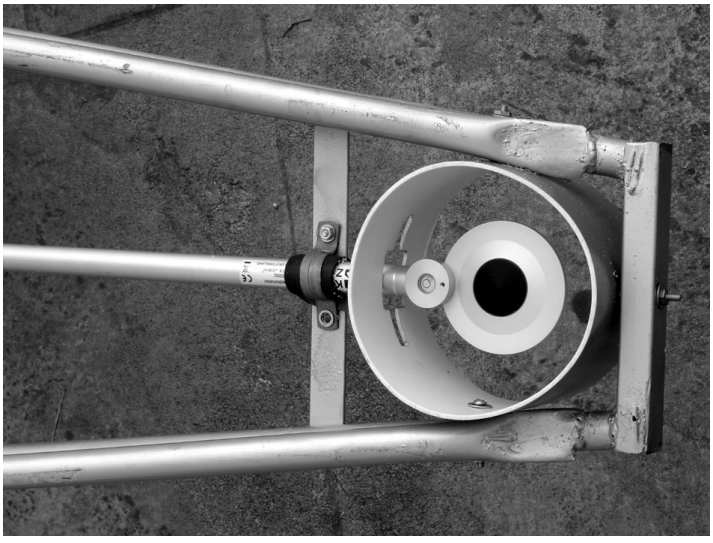

b

Fotos: Tarik Rezende de Azevedo

Figura 4.2 - Veículo com dispositivo dianteiro (a) para fixação de pirradiômetro (b). 


\subsubsection{ESPACIALIZAÇÃO DO EQUILÍBRIO TÉRMICO}

Os dados foram amostrados com a utilização de um sistema de aquisição (micrologger) fabricado pela Campbell Scientific Inc. (CSI), modelo CR3000, $\mathrm{n}^{\mathrm{o}}$ de série 1189. Este equipamento é composto de 14 canais e está munido de duas baterias ácidas de $9 \mathrm{~V}$ cada e recarregáveis. A referência geográfica de todos os percursos foi obtida com a utilização de um sistema manual de posicionamento por satélite GARMIN (GPS), modelo GPS12.

A amostragem foi realizada a uma freqüência de $0,5 \mathrm{HZ}$, e os dados observados armazenados inicialmente a um intervalo de um minuto. Posteriormente, o período de armazenamento foi gradativamente reduzido para 30 segundos e, em seguida, para 10 segundos, sendo elevada, assim, a resolução temporal do conjunto de dados. Foram verificados também os valores extremos (máximo e mínimo) observados.

Para quantificação da temperatura do ar foi utilizado o sensor RM Young, modelo RTD, com $\mathrm{n}^{\mathrm{o}}$ de série TS11222. Este aparelho é sensível a uma amplitude térmica de $\pm 50^{\circ} \mathrm{C}$, e foi acomodado no interior de uma tubulação ventilada na extremidade posterior da cobertura do veículo.

O procedimento fundamenta-se na utilização de uma plataforma móvel montada sobre o veículo motorizado, que é utilizado como um laboratório móvel, composto de uma plataforma instrumental instalada sobre a sua cobertura, além do dispositivo para observação dos fluxos radiativos que é instalado na proa do veículo (Fig. 4.2a).

A resolução espacial é variável, e depende fundamentalmente da velocidade do veículo. Nas vias expressas ou auto-estradas, raramente, atinge-se uma velocidade média inferior a 30 $\mathrm{kmh}^{-1}$, mas nas ruas e avenidas é possível obter-se uma velocidade média em torno de 10 $\mathrm{kmh}^{-1}$.

Considerando-se uma resolução temporal de 1 minuto para o armazenamento dos dados, e uma velocidade de deslocamento média em torno de $30 \mathrm{kmh}^{-1}$, atinge-se uma resolução espacial média de armazenamento em torno de $500 \mathrm{~m}$. Ou em termos de uma resolução temporal de 2 segundos para a amostragem dos dados, e a mesma velocidade de deslocamento, atinge-se uma resolução espacial média de amostragem em torno de $15 \mathrm{~m}$. 
Em situações de tráfego mais intenso, mantendo-se as mesmas resoluções temporais, porém com uma velocidade média em torno de $40 \mathrm{kmh}^{-1}$, a resolução espacial diminui, obtendo-se para o armazenamento uma resolução em torno de $700 \mathrm{~m}$, e para a amostragem em torno de 20 m. Em situações opostas, mantendo-se as mesmas resoluções temporais de armazenamento e amostragem, mas com uma velocidade média em torno de $20 \mathrm{kmh}^{-1}$, a resolução espacial aumenta para $300 \mathrm{~m}$ e $10 \mathrm{~m}$, respectivamente.

Por outro lado, aumentando-se a resolução temporal de armazenamento dos dados para um período de apenas 10 segundos, pode-se alcançar a mesma resolução espacial de armazenamento em torno de $300 \mathrm{~m}$, mesmo com velocidades superiores a $100 \mathrm{kmh}^{-1}$. No entanto, como a velocidade média praticada é raramente superior a $60 \mathrm{kmh}^{-1}$, tal elevação na resolução temporal resulta em uma resolução espacial para os dados armazenados de até 170 $\mathrm{m}$.

\subsubsection{Transetos específicos}

A seguir serão apresentadas as observações feitas a partir dos dados coletados em um trajeto de cerca de 2,6 km, abrangendo as Avenidas Cerro Corá e Heitor Penteado (Fig. 4.3), desde o cruzamento com a Avenida São Gualter até o cruzamento com a Avenida Pompéia.

Este experimento ilustra a série de levantamentos que têm sido realizados na região metropolitana da cidade de São Paulo, e alguns detalhes do armazenamento de dados. Todos os elementos observados foram armazenados em quatro arquivos distintos, correspondendo aos valores médios, ao desvio padrão e aos valores máximos e mínimos absolutos observados em cada um dos intervalos de armazenamento.

O intervalo de armazenamento dos dados foi sendo restringido no decorrer dos experimentos, a partir de um período de 60 segundos até se alcançar um período de armazenamento dos dados de 10 segundos. 

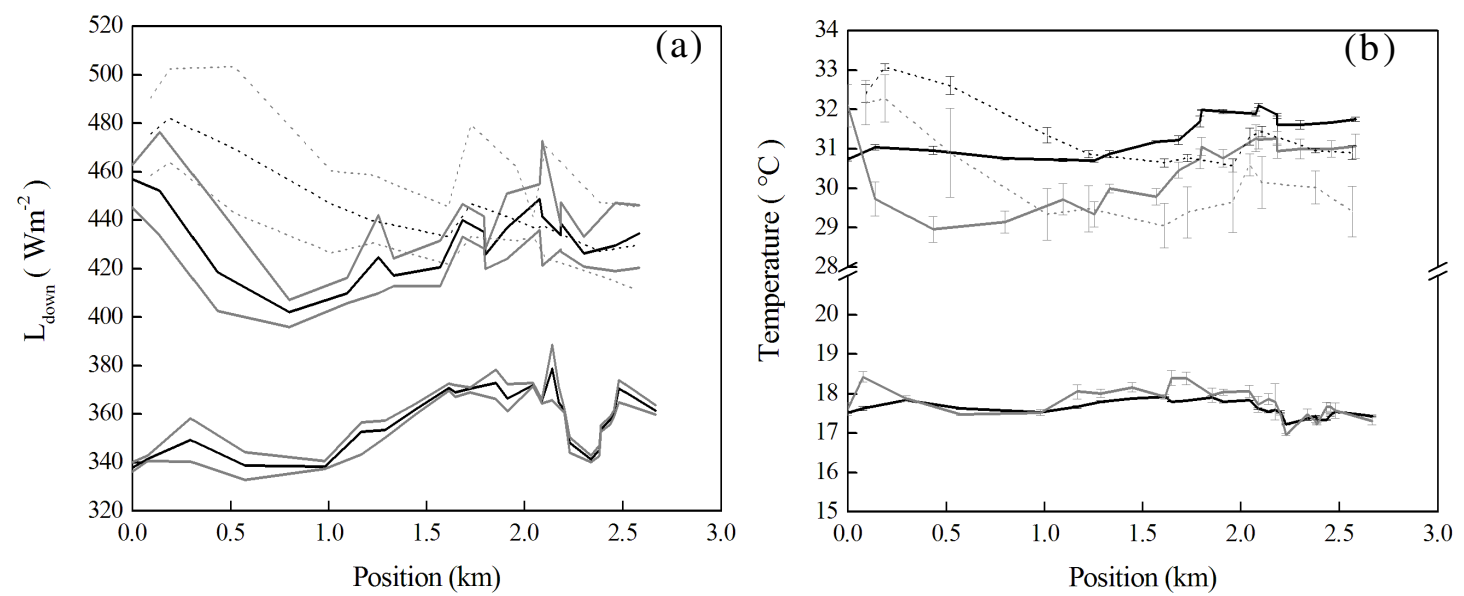

Figura 4.3 - Distribuição espacial do fluxo L $\downarrow$ (a) e das temperaturas do ar (linha escura) e do anel (linha clara) ao redor do radiômetro (b) através das Avenidas Cerro Corá e Heitor Penteado, desde a Avenida São Gualter até o cruzamento com a Avenida Pompéia, nos dias 21 de maio (linhas contínuas abaixo), $1^{\circ}$ de março (linhas contínuas acima) e 16 de fevereiro (linhas pontilhadas acima) de 2007. Também são representados os máximos e mínimos (linhas claras) observados para L $\downarrow$ e o desvio (barras verticais) observado para as temperaturas.

Este percurso específico apresentado foi percorrido em três ocasiões distintas. Inicialmente, na tarde de 16 de fevereiro de 2007, uma sexta-feira, entre $14 \mathrm{~h} 40 \mathrm{~min}$ e $14 \mathrm{~h} 55 \mathrm{~min}$. Uma tarde ensolarada, com nuvens. Este experimento durou cerca de 15 minutos e foi o mais demorado. Havia maior tráfego de veículos, especialmente por tratar-se de véspera do feriado prolongado de Carnaval. Os dados foram armazenados a intervalos de 60 segundos.

Posteriormente, na tarde de $1^{\circ}$ de março de 2007, uma quinta-feira, entre $14 \mathrm{~h}$ 01min e $14 \mathrm{~h}$ $11 \mathrm{~min}$. Uma tarde também ensolarada, porém, quase sem nuvens. Este experimento foi mais rápido, e durou cerca de 10 minutos. Apesar de tratar-se de um dia útil típico, não havia um tráfego de veículos tão intenso. Os dados foram armazenados a intervalos de 30 segundos.

E finalmente, na manhã de 21 de maio de 2007, uma segunda-feira, entre $06 \mathrm{~h} 43 \mathrm{~min}$ e $06 \mathrm{~h}$ 52min. Um início de manhã estrelado, e com nuvens. Este foi o experimento mais rápido, durando aproximadamente 9 minutos. O tráfego de veículos ainda era reduzido, como habitualmente observa-se após um fim de semana. Os dados foram armazenados a intervalos de 10 segundos. 


\subsubsection{2. Área metropolitana}

A totalização de um conjunto muito maior de transversos foi atingida, envolvendo um percurso total de $2.250 \mathrm{~km}$ na área da RMSP. A complexidade em analisar objetivamente as observações registradas, em todo o conjunto de travessias realizadas na área metropolitana, envolve dois problemas cruciais. Inicialmente, a não concordância temporal entre os instantes em que ocorre a observação dos fluxos e os instantes em que ocorre a referência geográfica. Isto porque os dois sistemas de aquisição de dados, micrologger e GPS, funcionaram independentemente. Após a aquisição dos dados de fluxo, apresentou-se um segundo problema, a descentralização dos dados estatísticos em diferentes arquivos que compõem a essência do banco de dados. Fato este inerente à natureza do sistema programado para ativar o micrologger.

Para que estes problemas fossem sanados e houvesse a possibilidade de realização de uma análise objetiva sobre os dados, foram idealizados dois programas auxiliares. Ambos os programas escritos em Fortran e compilados de maneira satisfatória para todo o conjunto de experimentos.

O primeiro programa consiste essencialmente em interpolar linearmente, através da evolução temporal, as coordenadas $(\mathrm{C})$ das posições geográficas referenciadas:

$$
C(t)=C_{0}+\left(t-t_{0}\right) \cdot \frac{\partial C}{\partial t}
$$

Sendo $t$ o instante do registro do valor da temperatura, armazenado no micrologger, e $t_{0}$ o instante imediatamente anterior ao qual corresponda algum valor de referência geográfica $\left(C_{0}\right)$ armazenado no GPS

Originou-se, desta maneira, um arquivo tratado para as coordenadas, fundado em uma grade temporal regular e coincidente com a grade temporal do micrologger. Por outro lado, o segundo programa tem por objetivo a leitura e centralização dos dados estatísticos que constituem os fluxos observados, em um único arquivo que é tratado em um segundo momento para aglutinar os dados das referências geográficas.

Deste modo todos os dados, coletados em todas as travessias, foram unificados em um único arquivo que passou a constituir-se no objeto central das análises. Com esta realização, foi possível observar uma primeira imagem (Fig. 4.4) da distribuição espacial média de todos os 
dados coletados. Esta primeira representação foi feita na forma de um grande transverso bidimensional, composto pela sucessão de travessias realizadas nos diversos dias. Nesta representação fundiram-se todos os aspectos, que a partir deste momento devem ser detalhados. Incluiu-se nesta associação diversas componentes: a natureza sazonal, a variabilidade diurna e noturna, a variabilidade topo climática, a configuração espacial das diversas ocupações do solo na metrópole e a interferência dos ritmos das atividades humanas.

A variabilidade dos dados observados sugeriu uma distribuição de freqüências (Fig. 4.5) que parecem assumir características de uma distribuição normalizada. A temperatura do ar observada na RMSP, ficou confinada a um intervalo definido por um valor máximo próximo a $36^{\circ} \mathrm{C}$ e um valor mínimo ligeiramente superior a $8^{\circ} \mathrm{C}$. Nota-se, assim, uma descontinuidade entre as diversas observações, e uma variabilidade característica de cada uma delas.

Padrões semelhantes foram observados para a temperatura do anel ao redor do radiômetro. Com exceção de alguns poucos episódios, há uma tendência geral de não extrapolação da amplitude observada para a temperatura do ar. Analisando-se a distribuição de frequiência entre as duas temperaturas observadas, foi possível perceber de uma maneira mais clara a concordância satisfatória entre estes dados, além de concordarem em amplitude, suas distribuições são também muito semelhantes. Alguma variação mais significativa pôde ser observada próximo aos valores extremos, mas em torno dos valores modais há um padrão praticamente idêntico.

Para as classes de temperatura em que houve uma boa concordância entre os valores para o ar e os valores para o anel, verificou-se, em geral, freqüências ligeiramente superiores para o ar. Isto se deve em parte ao fato de as observações sobre a superfície do anel não terem sido realizadas em alguns experimentos. 

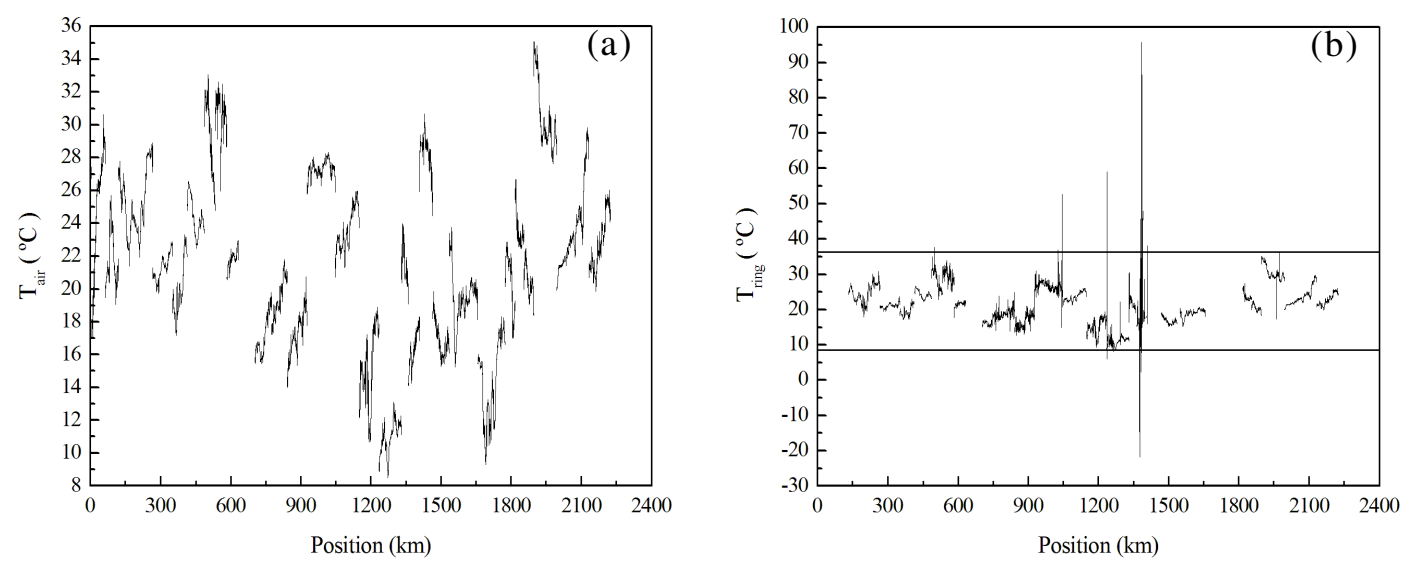

Figura 4.4 - Variabilidade espacial, em transverso, das magnitudes amostradas da temperatura do ar (a) e da temperatura sobre a superfície do anel de PVC (b).
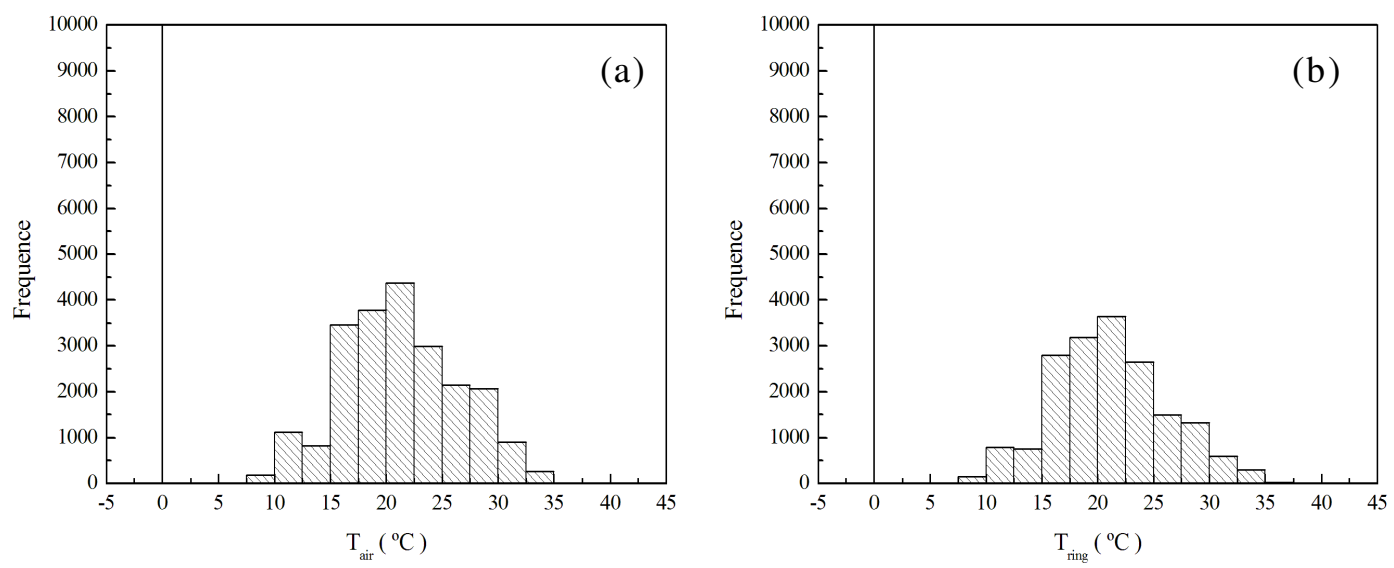

Figura 4.5 - Histogramas das magnitudes amostradas da temperatura do ar (a) e da temperatura sobre a superfície do anel de PVC (b).

As distribuições das amostragens, da temperatura do ar e da temperatura do anel, apresentam padrões semelhantes. Isto sugere, para observações em superfície, ocorrência do equilíbrio térmico entre a superfície do anel que abriga o radiômetro e o ar que flui sobre o dispositivo. Possibilitando desta maneira a ocorrência de padrões térmicos semelhantes entre o sensor e o meio circundante, e portanto validando as observações do fluxo $\mathrm{Q}^{*}$, e principalmente de sua componente $\mathrm{L}^{*}$, realizadas com este dispositivo em um ambiente tipicamente urbano, densamente povoado, onde a instalação de sensores fixos envolve grandes dificuldades.

Observa-se, porém, na distribuição espacial da temperatura do anel algumas distorções que não comprometem a validade dos resultados, mas que deveriam ser esclarecidas a propósito da utilização deste dispositivo em outras situações experimentais encontradas em campo. 
A principal distorção verificada na temperatura do anel (Fig. 4.4b) ocorreu em torno da posição $1300 \mathrm{Km}$, e corresponde a uma variação abrupta em sua amplitude que chega a superar em mais de 100\% a amplitude geral observada para a temperatura do ar. Este episódio ocorreu em observações realizadas no início da manhã do dia 4 de agosto de 2007, durante a estação seca. Nesta ocasião percebeu-se um padrão de forte inversão térmica e resfriamento noturno, com verificação de espessa camada de orvalho sobre a superfície do veículo e névoa densa abaixo das coberturas dos canyons urbanos. Foi uma situação extremamente singular em relação a outras observações realizadas na mesma área.

É possível portanto, que discrepâncias verificadas nos padrões observados da temperatura do anel estejam associadas não propriamente à interferência direta do fluxo de energia emanado pelo motor do veículo, mas sim a um efeito da umidade do ar sobre o sensor termopar acoplado sobre a superfície interna do anel. O sensor termopar é constituído por um filamento metálico extremamente fino e maleável, fixo em sua extremidade por uma fina película aderente. É muito provável que a condensação de vapor de água sobre este filamento irá alterar significativamente as propriedades condutivas do elemento constituinte do sensor, modificando diretamente o sinal amostrado.

Nos resultados localizados observa-se uma tendência similar entre as variabilidades da temperatura do anel e do ar (Fig. 4.3b), com a temperatura do anel apresentando desvios significativamente maiores, sobretudo nos experimentos diurnos. Estes maiores desvios encontrados para a temperatura do anel representam a resposta direta do efeito de ventilação induzida sobre o dispositivo, pelo deslocamento do conjunto, em contrapartida à tendência de aquecimento da superfície do anel pela incidência do calor proveniente do veículo utilizado e de eventual incidência direta da radiação solar.

Percebeu-se durante os experimentos diurnos valores médios da temperatura do anel sistematicamente inferiores à temperatura do ar observada, com a diferença entre elas variando desde cerca de $0,5^{\circ} \mathrm{C}$ até quase $2{ }^{\circ} \mathrm{C}$, assegurando-se não haver uma fonte adicional indesejável de calor sobre o sensor. Este padrão é resultado do efeito combinado entre episódios de cessação do deslocamento impostos pelas condições de tráfego (semáforos ou trechos congestionados), e as características térmicas do material que constitui o anel, principalmente em situações de sombreamento do dispositivo pelas obstruções das paredes ou coberturas urbanas. A capacidade térmica do anel é inferior àquela do ar, o que contribui para uma dissipação do calor sensível muito mais eficiente. Sobretudo imaginando-se uma 
condição de fluxo turbilhonar ao redor do dispositivo, que naturalmente é induzida pelo deslocamento do veículo.

Durante o experimento noturno (Fig. 4.3b, abaixo) verificou-se uma proximidade média do equilíbrio térmico entre a superfície do anel e o ar. No entanto, há uma tendência variacional com valores ligeiramente superiores da temperatura do anel, com diferenças em geral não superiores a $1{ }^{\circ} \mathrm{C}$ e na maior parte do trajeto inferior a $0,5^{\circ} \mathrm{C}$. Estes episódios de aquecimento estão associados ao efeito térmico do motor do veículo, quando ele se encontra estacionado em semáforos, mas que logo são dissipados ao reiniciar-se o deslocamento do conjunto.

Em termos dos padrões médios simultaneamente observados para o fluxo L $\downarrow$ (Fig. 4.3a), tanto nos casos diurnos como noturno, percebe-se uma concordância satisfatória entre a variabilidade espacial dos padrões de fluxos radiativos termais e os correspondentes padrões térmicos. Mesmo admitindo-se os extremos absolutos verificados para o fluxo L $\downarrow$. Portanto, pode-se enfim considerar com razoável grau de confiabilidade, a variabilidade da amplitude verificada para o fluxo $\mathrm{L}^{*}$ com o dispositivo proposto, como efeito direto da componente $\mathrm{L} \downarrow$ do meio urbano circundante sobre o indivíduo.

\subsubsection{VARIABILIDADE DE $Q^{*}$}

Os climas na cidade de São Paulo apresentam uma complexidade espacial, à qual se associam simultaneamente tanto às características naturais da região quanto às características de sua ocupação urbana (TARIFA e ARMANI, 2001).

Elementos superficiais interferem na constituição destes climas, e conseqüentemente nos fluxos de energia recebidos e emitidos no interior da camada de coberturas. Uma das principais fontes e também sumidouro de energia nesta camada, constitui-se no saldo radiativo $\left(Q^{*}\right)$.

Este saldo normalmente define-se como a diferença entre os fluxos radiativos em ondas curtas (K) e longas (L) e, portanto, constitui-se também em um fluxo. Apesar da energia estar sendo 
irradiada e emitida em todas as direções, especialmente no interior da camada de coberturas, em geral estes fluxos são mensurados e representados na direção vertical:

$\mathrm{Q}^{*}=(\mathrm{K} \downarrow-\mathrm{K} \uparrow)+(\mathrm{L} \downarrow-\mathrm{L} \uparrow)$

Ou, em experimentos que ocorram sobre superfícies inclinadas, caso de um veículo automotor deslocando-se sobre a topografia, poderiam ser compreendidos como os fluxos ortogonais a elas.

Quando o fluxo Q* é observado em torres meteorológicas, situadas acima das coberturas dos canyons, verifica-se a sua natureza conservativa no espaço, para uma área urbanizada (SCHMID et alii, 1991). Além dos limites da superfície urbana há tendência em homogeneização dos fluxos energéticos, tornando-se representativos da cidade para uma análise em escala regional (OKE et alii, 1999). A variabilidade espacial dos fluxos conservase, mantendo-se uniforme através de uma região dominada pelos efeitos de um certo aglomerado urbano.

Porém, abaixo das coberturas, as diferenciações geométricas e constituintes dos elementos que compõem a paisagem urbana, e também sua variabilidade espacial podem resultar em uma diversidade de padrões em $Q^{*}$ de maneira alguma óbvia e sequer conservativa (MACHADO e AZEVEDO, 2006b). As áreas fontes para o saldo radiativo passam também a não ser mais fixas, assim como já eram consideradas móveis as áreas fontes para os fluxos turbulentos de ar. Veículos em deslocamento e a própria movimentação dos indivíduos estão sujeitos a alterações constantes também em relação aos fluxos radiativos. Modelos matemáticos podem não ser capazes de identificar tal variabilidade temporal e espacial, por uma resolução limitada. Mas esta variabilidade existe, e as pessoas que caminham pelas cidades são capazes de percebê-la.

A cidade é o lugar onde as pessoas vivem e desenvolvem suas atividades. $\mathrm{O}$ detalhamento temporal e espacial dos fenômenos nos climas urbanos (OKE, 1987), nesta escala de vida, é uma das metas que tem sido sistematicamente buscada por Tim Oke e seus seguidores.

O sensoriamento remoto dos climas urbanos (VOOGT e OKE, 2003) apresenta-se como uma técnica que vem sendo desenvolvida e aperfeiçoada através das últimas décadas. Não se limitando apenas à utilização de sensores em plataformas móveis, mas também sensores acoplados a veículos (VOOGT e OKE, 1998b), deslocando-se através das vias de uma cidade. 
Medidas com radiômetros posicionados abaixo das coberturas urbanas já têm sido experimentadas em escala real ou modeladas em escala reduzida (VOOGT e OKE, 1991). Especialmente em termos dos fluxos de ondas longas, para estimativa de um panorama mais preciso da distribuição térmica através da intrincada superfície urbana (VOOGT e OKE,1997), que não repouse apenas sobre as limitações geométricas do ponto de vista do satélite.

Todavia, ao assumir-se a componente de ondas curtas do fluxo radiativo, aumenta-se o grau de complexidade da análise para a camada abaixo das coberturas e não se tem encontrado na literatura estudos sistemáticos a este respeito. Surge, portanto, como desafio à utilização de radiômetros expostos às condições cotidianas diurnas que as pessoas experimentam no interior de uma cidade. Devendo seus resultados serem interpretados como efeito combinado entre os fluxos termais e a irradiação solar através do ambiente urbano.

Dois casos são, portanto, investigados neste trabalho. Inicialmente um setor mais extenso, abrangendo uma área naturalmente dominada desde o Clima Tropical Úmido Serrano da Cantareira-Jaraguá (N-II) até o Clima Tropical Úmido de Altitude do Planalto Paulistano (NI). E em termos do caráter urbano que lhe é peculiar, desde a Unidade Climática Urbana da Periferia (U-II) até a Unidade Climática Urbana Central (U-I). Posteriormente um setor mais restrito, totalmente imerso no domínio dos climas N-I e U-I (TARIFA e ARMANI, 2001, p.49 com siglas adaptadas).

As características (TARIFA e ARMANI, 2001, mapa 2.1 anexo) do primeiro setor investigado fundamentam-se na transição de uma área com topos planos, ventilados, com boa dispersão de poluentes e temperaturas amenas, para uma área com elevada estabilidade atmosférica noturna e matinal. Enquanto para o segundo setor predomina o forte aquecimento diurno e a má dispersão de poluentes.

\subsubsection{Amplificação diária}

Os transetos percorridos foram georreferenciados (Fig. 4.6) e correspondem a observações realizadas no verão de 2006 / 2007.

Durante o primeiro transeto (Fig. 4.6a) percorreu-se a via Anhanguiera, desde as proximidades do trevo de Perus, passando-se pela Vila Jaguará, e atingindo-se a Marginal dos Pinheiros, 
próximo à ponte Ari Torres. Este trajeto foi realizado entre a primeira e a segunda hora da manhã do dia 30 de dezembro, um sábado de feriado prolongado. A velocidade média desenvolvida esteve em torno de $30 \mathrm{kmh}^{-1}$. As condições meteorológicas foram de céu claro e calmaria. No segundo transeto (Fig. 4.6b) realizado no mesmo intervalo de tempo que o primeiro, em torno de 50 minutos, percorreu-se um setor entre a porção oeste e a porção central da cidade de São Paulo, desde os bairros da Lapa e Água Branca, passando pela Avenida Cardoso de Almeida e atingindo os bairros de Higienópolis e Santa Cecília. Este trajeto foi realizado durante à tarde do dia 07 de fevereiro, uma quarta-feira dia útil comum. A velocidade média desenvolvida foi relativamente inferior ao primeiro caso, em torno de 10 $\mathrm{kmh}^{-1}$. As condições meteorológicas (Fig. 4.7) foram de tempo ensolarado com a presença de cumulus congestus e vento fraco.

Não houve registro da umidade absoluta, e aparentemente os experimentos ocorreram sob condições não saturadas. Não foi observado nevoeiro durante a realização do primeiro, apesar de ter ocorrido precipitação intensa após a realização do segundo.

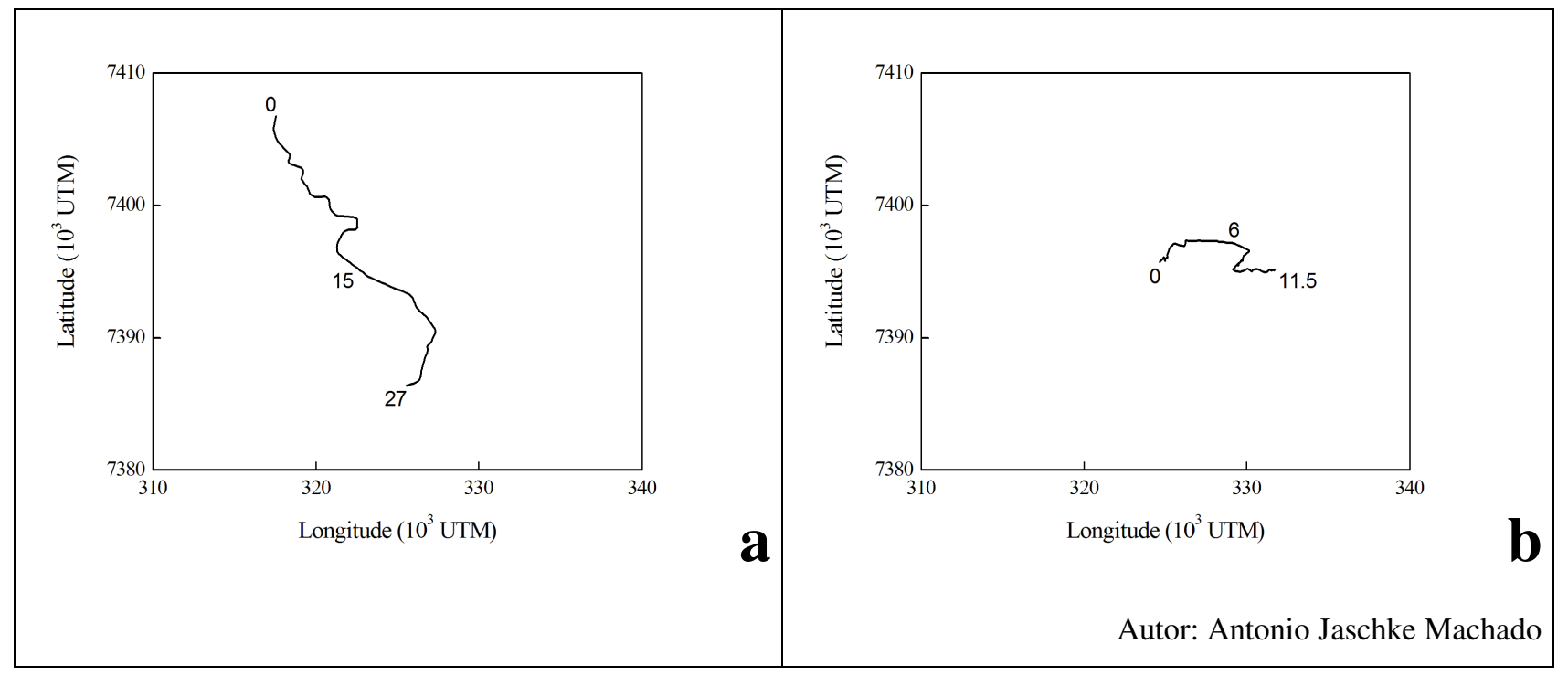

Figura 4.6 - Percursos georreferenciados realizados com o laboratório móvel, no eixo Anhangüera - Marginal Pinheiros (a) e no eixo Francisco Matarazzo - Pacaembu - Higienópolis (b). Os números indicados através dos percursos representam determinadas posições em $\mathrm{km}$. 


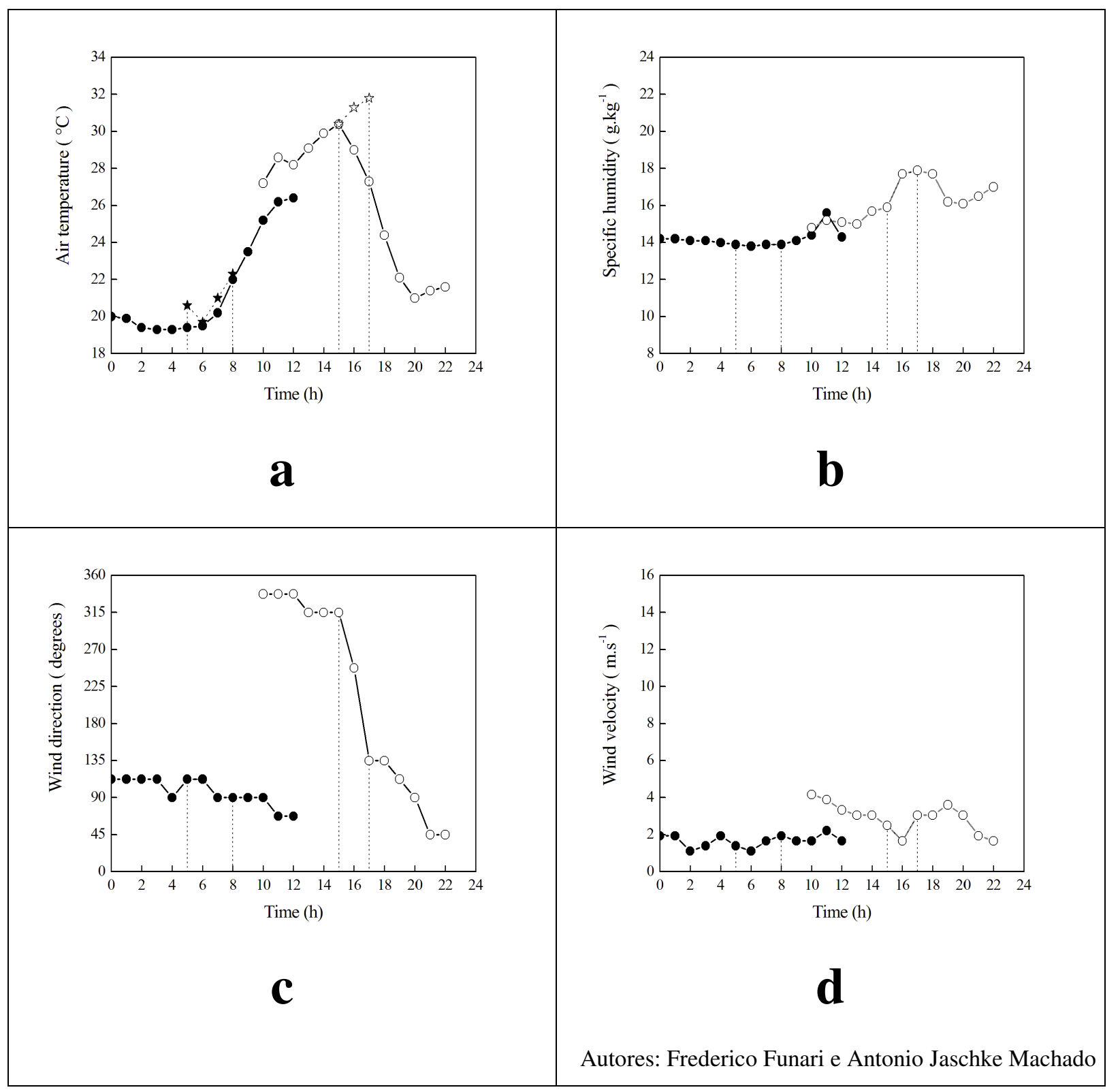

Figura 4.7 - Evolução temporal da temperatura do ar (a), da umidade específica (b) e da direção (c) e velocidade (d) do vento próximo à superfície, nos dias 30 de dezembro (círculo fechado) e 7 de fevereiro (círculo aberto), para uma estação meteorológica situada na porção sul da cidade de São Paulo e para o veículo em deslocamento nas ruas (estrela), em um período de 12 horas em torno do intervalo (polígonos entre as linhas verticais pontilhadas) de realização dos experimentos.

No decorrer dos dois experimentos foram observados padrões distintos de Q* (Fig 4.8), com pequena amplitude máxima para o primeiro caso (em torno de $50 \mathrm{Wm}^{-2}$ ) e grande amplitude máxima para o segundo caso $\left(500 \mathrm{Wm}^{-2}\right)$. Os perfis temporais foram corrigidos através da realização da georreferência, possibilitando a representação da distribuição espacial (Fig. 4.9) do fluxo de $\mathrm{Q}^{*}$ observado para a direção ortogonal às vias percorridas. Nota-se que os 
padrões são semelhantes, pois os percursos foram realizados de maneira contínua, e as mesmas amplitudes são mantidas.

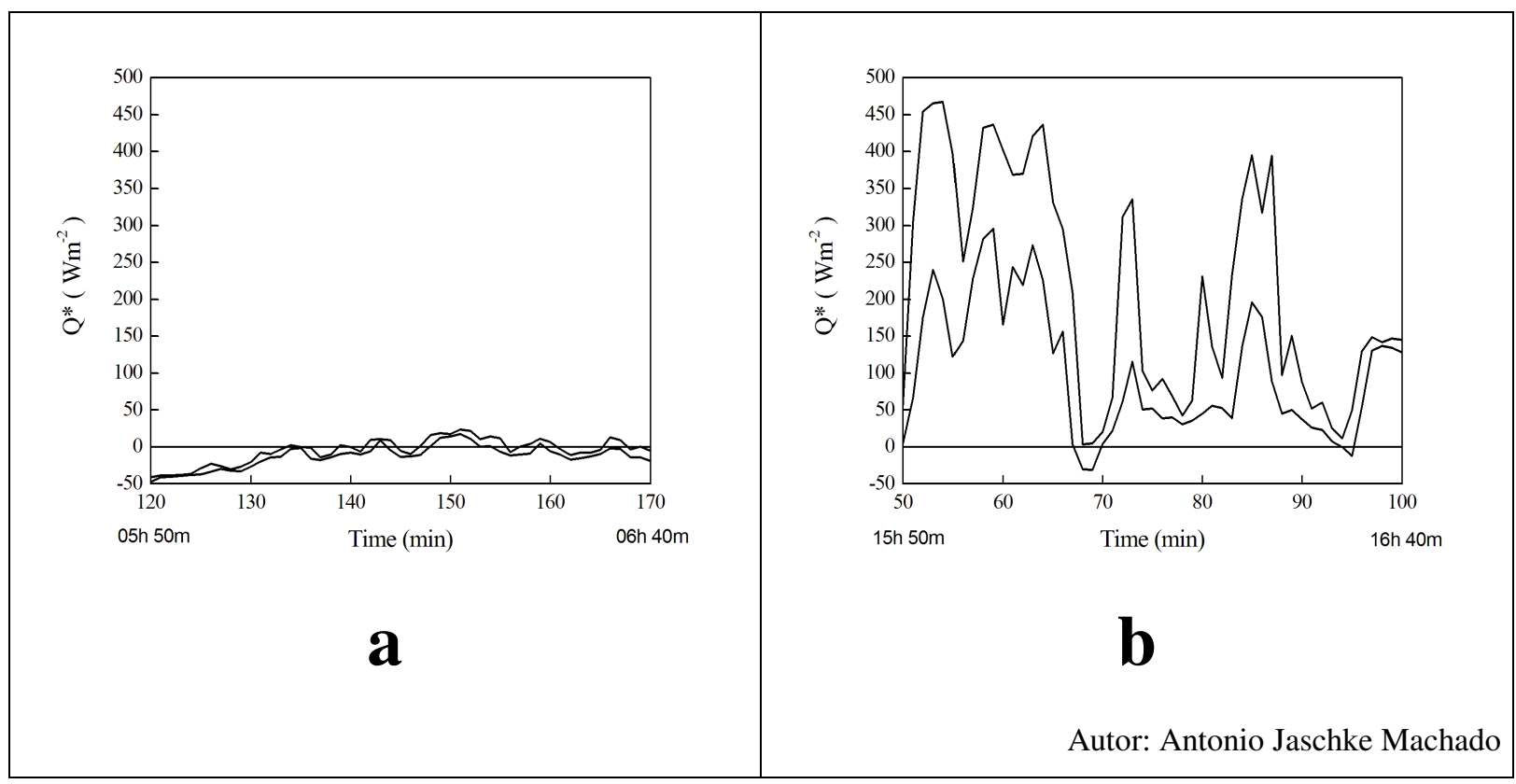

Figura 4.8 - Distribuição temporal do saldo radiativo máximo (acima) e mínimo (abaixo) absolutos observados no eixo Anhangüera - Marginal Pinheiros (a) e no eixo Francisco Matarazzo - Pacaembu - Higienópolis (b).

Apesar do primeiro experimento ter sido realizado no início da manhã, verificou-se um padrão ainda característico do período noturno, quando do ponto de vista meteorológico seriam esperados valores negativos para $Q^{*}$. Este padrão foi reforçado, sobretudo, pela presença inicialmente da barreira orográfica na margem setentrional do rio Tietê, e posteriormente pela presença de áreas urbanas intensamente verticalizadas na margem oriental do rio dos Pinheiros. Obstáculos, tanto naturais como antropogênicos, acabam retardando o horário do nascer do sol sob o ponto de vista de um observador que se desloca no interior de um canyon.

No entanto, também é observada uma tendência intermitente para oscilação de $\mathrm{Q}^{*}$ em torno do valor nulo (Fig. 4.9a), especialmente ao se deslocar da via Anhangüera para à Marginal dos Pinheiros, ou seja, de uma área com ocupação onde ainda predominam extensos setores arborizados e florestados para uma área com ocupação tipicamente urbana. $\mathrm{O}$ fluxo de $\mathrm{Q}^{*}$ passa a apresentar valores positivos intermitentes, indicativos de um aumento da componente radiativa recebida, supondo-se que a componente emitida pela superfície do piso dos canyons 
é mantida quase que de maneira constante, pela homogeneidade da cobertura deste piso e da pouca variabilidade térmica esperada para o intervalo observado.

Como a intensidade da radiação solar recebida ainda é muito fraca nesta situação, pode-se praticamente desprezá-la em comparação a amplitudes em torno de algumas dezenas de Watts. Portanto, há uma indicação considerável para que o aumento verificado no fluxo radiativo observado seja gerado fundamentalmente por emissão térmica a partir das coberturas e das paredes dos canyons e do ar que o preenche. Nestes termos, o aumento verificado em Q* pode estar associado à presença de viadutos e extensos muros no decorrer do trajeto, bem como à própria atmosfera poluída.

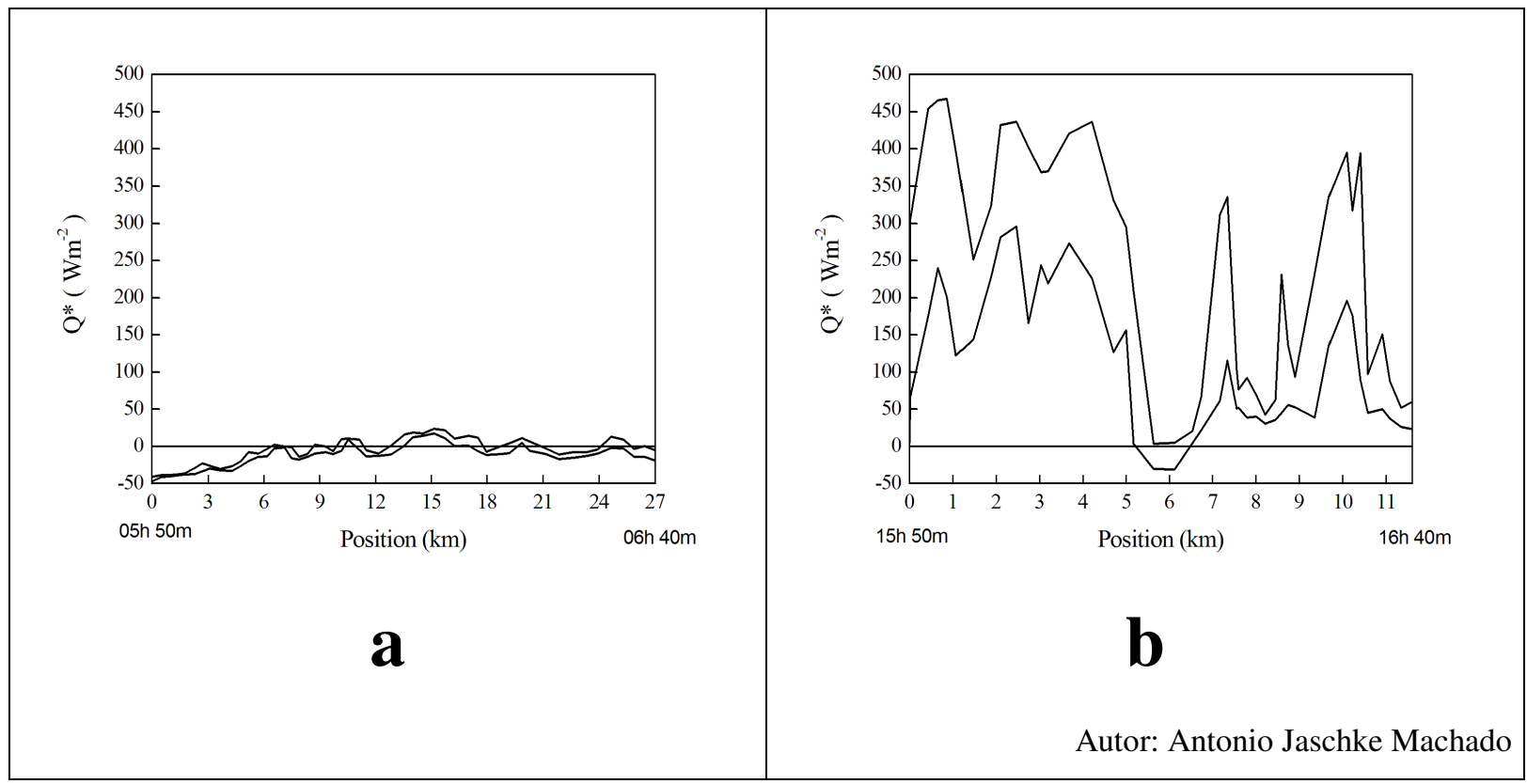

Figura 4.9 - Distribuição espacial do saldo radiativo máximo (acima) e mínimo (abaixo) absolutos observados no eixo Anhangüera - Marginal Pinheiros (a) e no eixo Francisco Matarazzo - Pacaembu - Higienópolis (b).

Por outro lado, o segundo experimento, realizado em uma típica tarde de verão, apresenta um padrão para $\mathrm{Q}^{*}$, característico do período diurno com valores marcadamente positivos, mantendo-se a priori o ponto de vista meteorológico em respeito à magnitude de $\mathrm{Q}^{*}$. Mas mesmo nesta situação, quando se passa para o ponto de vista de um observador situado abaixo das coberturas dos canyons, outra possibilidade parece ser viabilizada.

Nota-se neste caso, algumas tendências de redução abrupta no valor de Q* (Fig. 4.9b), podendo-se atingir inclusive valores negativos à plena "luz do dia". Este fenômeno parece ser mais evidente, e em essência associa-se à obstrução do fluxo solar irradiado através da 
atmosfera, aflorando subitamente o fato de que a superfície do piso do canyon emite mais do que recebe, ou seja, está mais aquecida. Os obstáculos nesta situação são constituídos por viadutos, edifícios mais elevados e também vegetação, pois não se pode desprezar nestes setores da cidade a presença de árvores que compõem a paisagem urbana.

Na Figura 4.10 busca-se localizar de maneira mais precisa dois destes episódios, que denotam um contraponto entre a expectativa meteorológica acima das coberturas e a realidade geográfica que envolve a camada de coberturas dos canyons.

São representados os setores aproximados, em torno das posições $15 \mathrm{~km}$ (Fig. 4.9a) e $6 \mathrm{~km}$ (Fig. 4.9b), onde há inversão no sinal de Q*. Estes setores correspondem, respectivamente, ao trecho da Marginal dos Pinheiros situado ao lado da Cidade Universitária, e ao trecho da Avenida Francisco Matarazzo situado ao lado do Parque da Água Branca, ambos percorridos na mesma direção (noroeste - sudeste).

Aparentemente, no primeiro caso, há indícios de que a inversão positiva em Q* (Fig. 4.9a) pode ser favorecida em boa parte pela presença do muro posicionado ao lado da raia olímpica da Cidade Universitária (Fig. 4.10a). Enquanto no segundo caso, há indícios de que a inversão negativa em Q* (Fig.4.9b) é favorecida pela presença de vegetação arbórea na fronteira entre o parque a via pública. Em ambas as situações o sensor esteve sob a influência destes elementos, fundamentalmente porque o veículo deslocou-se preferencialmente à direita destas vias.

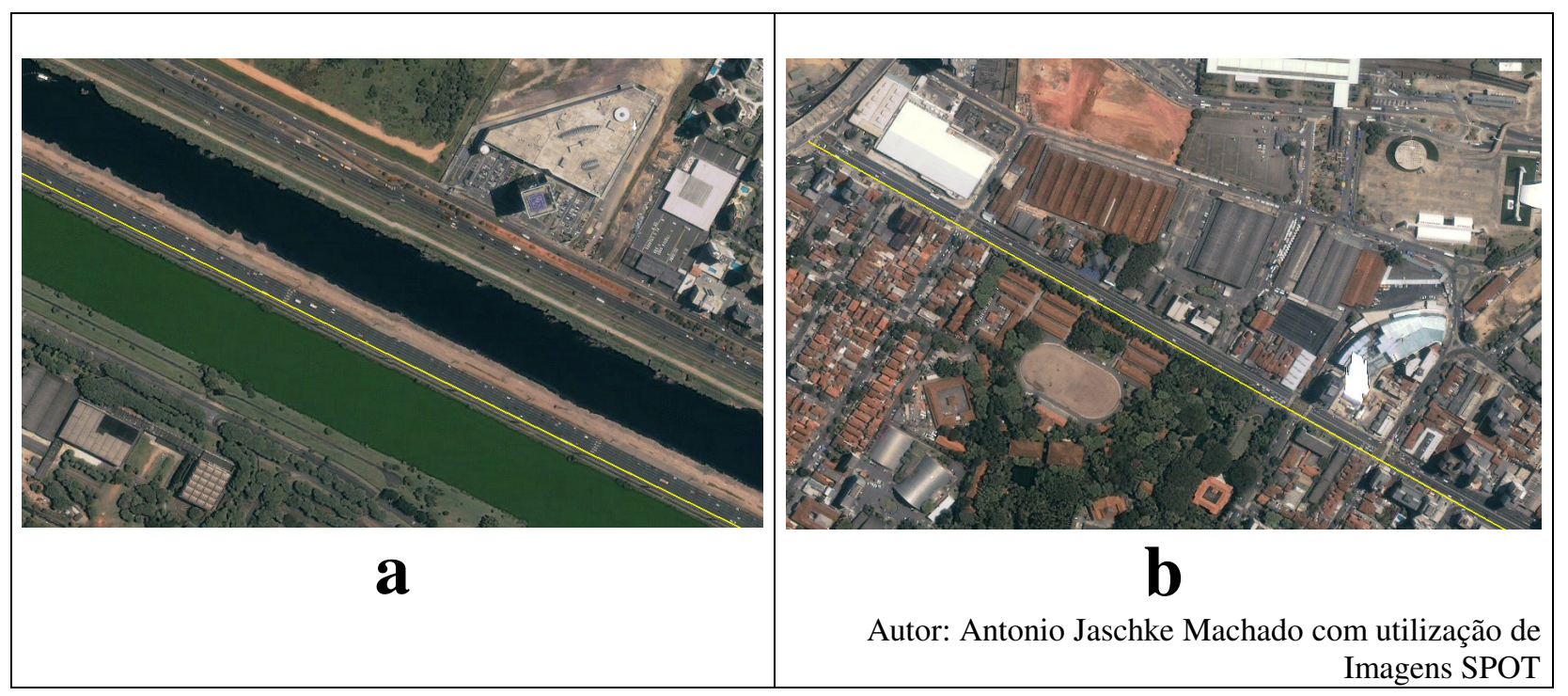

Figura 4.10 - Marginal dos Pinheiros (a) ao lado da Cidade Universitária, e Av. Francisco Matarazzo (b) ao lado do Parque da Água Branca. A linha reta clara indica o trajeto do veículo. 


\subsubsection{Atividade humana}

Além da ocupação do solo, outros fatores que podem ser suscitados a respeito dos padrões de Q* observados, dizem respeito ao ritmo horário do fenômeno e ao ritmo das atividades humanas na cidade (AZEVEDO, 2001).

Foi feita uma tentativa preliminar (Fig. 4.11) em verificar os padrões de $Q^{*}$ para segmentos dos mesmos trechos verificados nos experimentos apresentados anteriormente, e sob condições meteorológicas similares àquelas ocorridas nestes experimentos. No entanto, em horários distintos, basicamente que apresentassem um ângulo de elevação do disco solar semelhante (Fig. 4.11a) à situação observada anteriormente (Fig. 4.9b). E que também levassem em consideração o ritmo semanal das atividades da população, sendo realizados os novos experimentos em uma quinta-feira (Fig. 4.11a), dia útil, com tráfego de veículos mais intenso, e em um domingo (Fig. 4.11b) posterior a um dia de feriado.

É notável um mínimo principal (Ponte Cidade Jardim), e um mínimo secundário (Ponte Eusébio Matoso) observado em $\mathrm{Q}^{*}$, quando o veículo posiciona-se abaixo de pontes e viadutos (Fig. 4.11a). Além disso, o mínimo em $Q^{*}$ observado em uma tarde de dia útil (Fig.4.9b) na Avenida Francisco Matarazzo, em torno da fronteira com o Parque da Água Branca, parece preservar-se em intensidade e abrangendo um setor um pouco mais extenso (Fig. 4.11b) no início de uma manhã de domingo. Um mínimo, também negativo, um pouco mais acentuado é observado mais adiante desta localidade (Fig. 4.11b), que já era associado a um mínimo positivo de Q*, mas não muito pronunciado, no período da tarde (Fig. 4.9b). Este segundo setor abrange uma área bastante arborizada e com edifícios altos, entre a Praça Vilaboim e a praça Buenos Aires em Higienópolis, até a esquina com a Avenida Angélica.

Não é possível estabelecer a priori uma relação direta, entre o sentido de fluxo do saldo radiativo observado no interior da camada urbana de coberturas e o período do dia. Sendo talvez mais adequada uma relação com os tipos de clima da cidade.

Os experimentos realizados indicam que é possível a observação de valores positivos ou negativos de $\mathrm{Q}^{*}$ em diferentes horários. Este fato indica que este fluxo de energia não é espacialmente conservativo abaixo das coberturas, e sua variabilidade espacial deve ser fortemente influenciada pelos diversos tipos de ocupação do solo. 
Em geral, o fluxo Q* é pensado como um fluxo prevalecente na direção vertical. Isto se deve às observações realizadas acima das coberturas, que explicitam a grande relação entre trocas atmosféricas e superficiais em uma situação com "horizonte livre".

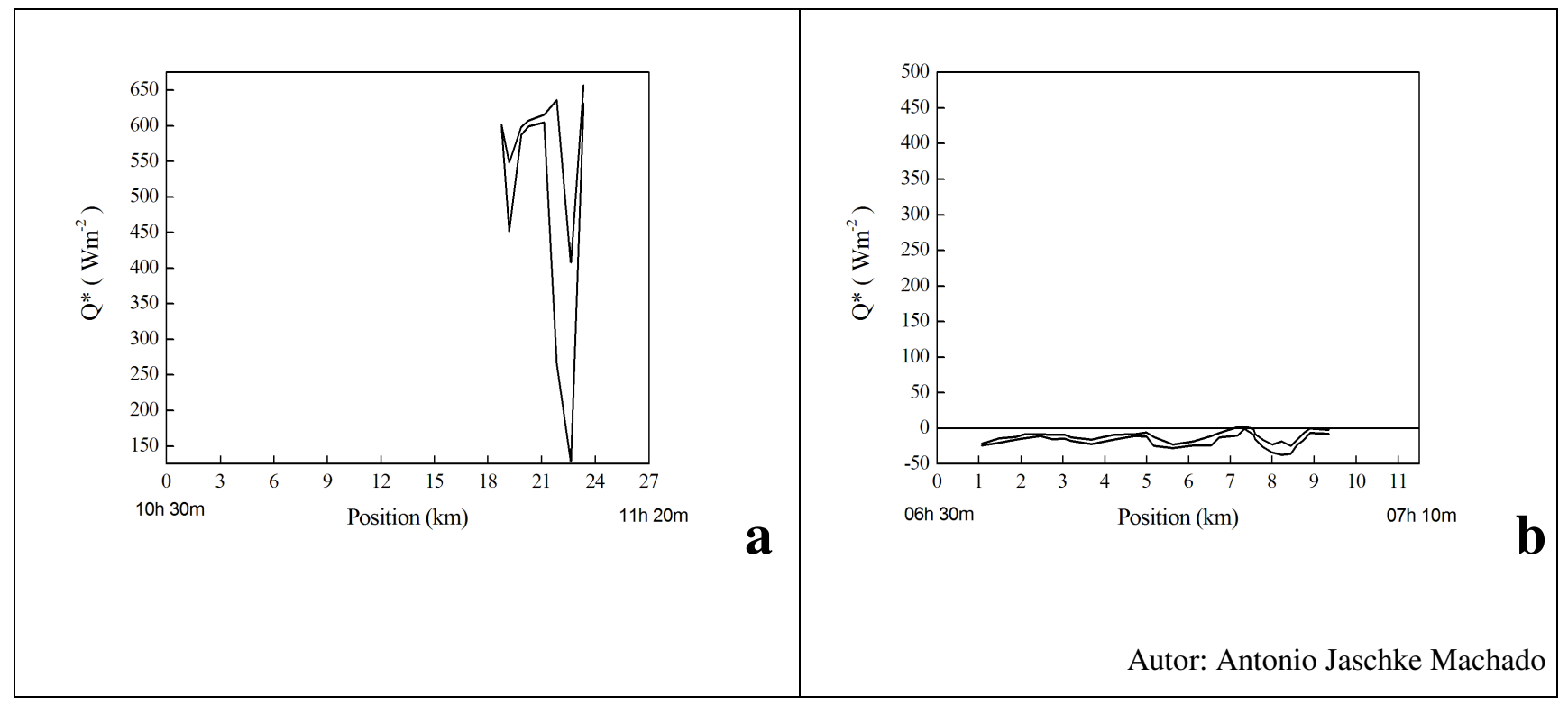

Figura 4.11 - Idem à Figura 4.9, para os dias 12 (a) e 22 de abril (b).

Se o fluxo Q* é pensado abaixo das coberturas, então as trocas radiativas horizontais entre as paredes dos canyons ou entre veículos poderiam passar a ter um papel relevante. Todavia, nestes casos seriam mais apropriadas medições fixas.

Portanto, entre setores com diferente constituição química do ar, como avenidas com tráfego intenso e parques urbanos, por exemplo, o método apresentado cumpre seu propósito. Fundamentado-se as observações em medições móveis, os fenômenos representados passam a pertencer a uma escala intermediária, entre a escala da cidade total e a escala de suas fontes unitárias.

Sobre as condições meteorológicas, nota-se no início da manhã ou no decorrer da tarde que a temperatura do ar nas ruas tende a ser mais elevada do que num local afastado destas, podendo superar $4^{\circ} \mathrm{C}$. Isso, com velocidades do vento baixas, em torno de $2 \mathrm{~m} . \mathrm{s}^{-1}$. No caso do segundo experimento, isto pode estar associado às alterações meteorológicas, tendo em vista a elevação da umidade específica e a inversão na direção do vento.

Nesta primeira aproximação, os padrões de Q* para horários com grande ângulo da elevação solar apresentam amplitudes semelhantes, tanto quando sob pontes e viadutos ou quando atravessando áreas arborizadas. Porém, a magnitude é elevada em um local com tráfego de 
veículos mais intenso e com um canyon urbano de largura maior, como é o caso das avenidas marginais. Para horários com baixa elevação solar, a magnitude de $\mathrm{Q}^{*}$ em áreas centrais da cidade, em locais próximos a parques e edifícios altos, torna-se próxima à verificada no setor que atravessa a periferia da cidade, em dias de feriado.

Em uma segunda aproximação, além de serem validadas as medições mediante o padrão térmico do anel de PVC, será necessário também se aprofundar um pouco mais em questões relativas à variabilidade temporal do fenômeno e à influência das atividades humanas sobre os dados obtidos. Afinal, as medições são realizadas em meio a tráfego e veículos, elemento diretamente associado a estas atividades. 


\subsection{Dimensão espacial dos dados georreferenciados}

\subsubsection{LUGARES}

\subsubsection{Mancha urbana}

Dentre todas as localidades visitadas até o mês de novembro de 2007, 27 localidades destacam-se por terem sido visitadas com maior freqüência (Tab. 5.1). A freqüência aqui, assim como no caso dos ritmos, corresponde a um certo número de dias. Ou seja, uma localidade visitada em dias diferentes, independentemente de ter sido visitada em horários distintos em um mesmo dia.

\subsubsection{Além da metrópole}

O conjunto de localidades visitadas, com tipos de ocupação potencialmente distintos, foi muito maior (Tab. 5.2). Algumas localidades foram visitadas com freqüência por uma mera necessidade logística. Seja porque estão próximas ao posto de comando dos experimentos, seja porque representam vias de acesso rápido a setores distantes, seja pelas suas particularidades físicas de interesse. 
Tabela 5.1 - Distribuição de amostragem dos lugares visitados com maior freqüência.

\begin{tabular}{|c|c|}
\hline Lugar & Freqüência \\
\hline Rua Dardanelos & 35 \\
\hline Av. Diógenes Ribeiro de Lima & 33 \\
\hline Rua PioXI & 30 \\
\hline Marginal Tietê & 16 \\
\hline Av. São Gualter & 15 \\
\hline Rua Tito & 14 \\
\hline Rua Pedroso de Morais & 13 \\
\hline Av. Marquês de São Vicente & 11 \\
\hline Viaduto da Lapa & 11 \\
\hline Rua Nª $S^{a}$ da Lapa & 10 \\
\hline Marginal Pinheiros & 9 \\
\hline Ponte do Piqueri & 7 \\
\hline Av. Cerro Corá & 7 \\
\hline Bairro City Lapa & 7 \\
\hline Av. Prof. Frederico Hermann Jr. (CETESB) & 7 \\
\hline Av. Brig. Faria Lima & 6 \\
\hline Praça Panamericana & 6 \\
\hline Rua Antonio Alarcon (Tr. Dardanelos-PioXI) & 6 \\
\hline Av. Francisco Matarazzo & 6 \\
\hline Av. do Estado & 5 \\
\hline Av. Ipiranga & 5 \\
\hline Rod. Anhangüera & 5 \\
\hline Rua Vergueiro & 5 \\
\hline Av. Paulista & 5 \\
\hline Av. Heitor Penteado & 5 \\
\hline Av. Sumaré & 5 \\
\hline Av. Queiroz Filho (Cemitério da Lapa) & 5 \\
\hline
\end{tabular}


Tabela 5.2 - Distribuição de amostragem dos 313 principais lugares visitados. São reconhecidos alamedas (Al), avenidas (A), bairros (B), cemitérios (Cem), colégios (Col), elevados (Elev), estádios, (Est), expressos (Exp), favelas (Fav), garagens (G), hospitais (Hosp), jardins (J), largos (L), marginais (M), municípios (Mun), parques $(\mathrm{P})$, pontes e viadutos $(\mathrm{Pt})$, praças $(\mathrm{Pc})$, rodovias $(\mathrm{Rod})$, ruas $(\mathrm{R})$, shopping centers (Shop), travessas $(\mathrm{Tr})$, trevos (Trev), túneis (T) e algumas localidades notáveis.

\begin{tabular}{|c|c|c|c|c|c|c|c|c|c|}
\hline Lugar & Freq. & Lugar & Freq. & Lugar & Freq. & Lugar & Freq. & Lugar & Freq. \\
\hline $\mathrm{ABC}$ & 2 & A.JoaoDias & 1 & B.CityLapa & 7 & L.Batata & 2 & Pt.EusebioM & 3 \\
\hline Al.BatPolicia & 1 & A.JuscelKubit & 1 & B.Educandari & 1 & L. Extra & 1 & Pt.Goldfaber & 2 \\
\hline Al.Nothmann & 2 & A.Lider & 1 & B.FreguesiaO & 1 & L.SaoBento & 1 & Pt.ImNordesti & 1 \\
\hline A.AbraaoMor & 1 & A.LinsVascon & 1 & B.Guaianaze & 1 & L.SaoFrancis & 2 & Pt.Jabaquara & 1 \\
\hline A.Aclimacao & 1 & A.MateoBei & 1 & B.Higienopol & 2 & M.Pinheiros & 9 & Pt. Jaguare & 3 \\
\hline A.AlcantMach & 2 & A.Mazzei & 1 & B.Ipiranga & 1 & M.Tiete & 16 & Pt. JMesquita & 1 \\
\hline A.Almirante... & 1 & A.MBoiMirim & 1 & B.Jaguare & 1 & MetroBFunda & 1 & Pt.Lapa & 11 \\
\hline A.AmarGurgel & 1 & A.Mercurio & 2 & B.LapaBaixo & 1 & Mun.Barueri & 1 & Pt.Limao & 2 \\
\hline A.Angélica & 1 & A.MiguelStef & 2 & B.LauzanPta & 1 & Mun.Cabreuv & 1 & Pt.MarMaluf & 1 \\
\hline A.Aricanduva & 1 & A.NacoesUni & 2 & B.Penha & 1 & Mun.Caieiras & 1 & Pt.Pacaembu & 2 \\
\hline A.AssisRibeir & 2 & A.Nordestina & 1 & B.Perus & 1 & Mun.Cotia & 1 & Pt.Piqueri & 7 \\
\hline A.Bandeirant & 3 & A.OlimpioSilv & 1 & B.S.Mateus & 2 & Mun.EmbuArt & 2 & Pt.Pompeia & 3 \\
\hline A.Brasil & 2 & A.OtacilioTom & 1 & B.SMiguelPta & 2 & Mun.EmbuGu & 1 & Pt.Remedios & 1 \\
\hline A.BrasLeme & 2 & A.Pacaembu & 4 & B.Tatuapé & 1 & Mun.Fr.Roch & 1 & Pt.RepMairip & 1 \\
\hline A.Brig.FarLim & 6 & A.Paulista & 5 & B.Tucuruvi & 1 & Mun.Guarulh & 3 & Pt.SecrAgric & 1 \\
\hline A.Brig.LuisAn & 2 & A.PedAlvCabr & 2 & B.VJaguara & 1 & Mun.Itapeciri & 1 & Pt.Socorro & 1 \\
\hline A.CerroCora & 7 & A.Pompeia & 3 & B.VilaMadale & 2 & Mun.Itaquaq & 2 & Pt.Tatuape & 3 \\
\hline A.Consolacao & 2 & A.Pr.Altino & 1 & B.VilaMatilde & 2 & Mun.Mairipor & 4 & Pt.Transamer & 2 \\
\hline A.CorifeuAM & 2 & A.Pr.JKenned & 1 & B.VNCachoeir & 1 & Mun.Maua & 1 & PçBuenAires & 2 \\
\hline A. Diogenes & 33 & A.Pr.TancreN & 1 & CampoMarte & 1 & Mun.Osasco & 1 & PçCharMuller & 2 \\
\hline A.DireitoHum & 1 & A.QueirozFilh & 2 & CampusCidU & 2 & Mun.PirapBJ & 1 & PçEnzoFerrar & 1 \\
\hline A.DomPedroI & 1 & A.RadialLest & 2 & CampusUNIP & 1 & Mun.RibeirPir & 1 & PçForumPinh & 1 \\
\hline A.DrArnaldo & 3 & A.Reboucas & 3 & CEAGESP & 1 & Mun.SantPar & 1 & PçJoaoMend & 3 \\
\hline A.Dru.Vilares & 1 & A.RicardoJafe & 1 & Cebolao & 1 & Mun.St.Andre & 2 & PçPanameric & 6 \\
\hline A.DuqCaxias & 2 & A.RioBranco & 2 & Cem. Lapa & 5 & Mun.SBernar & 2 & PçdoPatriarc & 2 \\
\hline A.EirasGarcia & 1 & A.RioPequen & 1 & CETESB & 7 & Mun.SCaetan & 2 & PçPordoSol & 1 \\
\hline A.EliseuAlmei & 1 & A.Rudge & 2 & Col.Mackenz & 2 & Mun.Suzano & 1 & PçRepublica & 1 \\
\hline A.EngCaetAlv & 1 & A.SalimFMal & 2 & Col.StoIvo & 1 & Mun.TaboaS & 4 & PçdaSe & 2 \\
\hline A.ErmanoMar & 4 & A.SantosDum & 1 & Elev.CosSil & 4 & P.Aclimacao & 1 & PçVilaboim & 2 \\
\hline A. EscPolitec & 1 & A.SaoGualter & 15 & EstPacaembu & 1 & P.AgBranca & 4 & PrefeitSPaulo & 2 \\
\hline A.Estado & 5 & A.SaoJoao & 3 & ExpTirad & 2 & P.Carmo & 1 & Rep.Mairipor & 2 \\
\hline A.EstEGuCipo & 1 & A.SaoLuis & 1 & Fav.ABC & 1 & P.D.PedroII & 1 & Rodoanel & 3 \\
\hline A.EstItapeciri & 1 & A.Semaneiro & 1 & Fav.PtJM.MT & 1 & P.Ibirapuera & 2 & Rod.Anchieta & 2 \\
\hline A.FMatarazzo & 6 & A.Sumare & 5 & FestaAchiropi & 1 & P.Luz & 1 & Rod.Anhang & 5 \\
\hline A.FranMorato & 3 & A.Tiradentes & 1 & FAAP & 2 & P. Principes & 1 & Rod.AyrtSenn & 3 \\
\hline A.Guarapiran & 1 & A.Villares & 1 & G.ACarolina & 3 & P.VilaLobos & 3 & Rod.Bandeir & 1 \\
\hline A.Guarulhos & 1 & A.23deMaio & 2 & G.Iperoig & 1 & PatiodoColeg & 1 & Rod.CasteloB & 2 \\
\hline A.HPenteado & 5 & A.VitalBrazil & 2 & HortoFloresta & 1 & Pt.Antarctica & 1 & Rod.EmbuCot & 2 \\
\hline A.HenrSchau & 4 & A.ZakiNarchi & 1 & Hosp.StCasa & 1 & Pt.Aricanduva & 1 & Rod.FernDias & 4 \\
\hline A.Ibirapuera & 1 & B.Aclimacao & 1 & J.America & 1 & Pt.AvAlmirant & 1 & Rod.Imigrant & 1 \\
\hline A.IgnAnhaiaM & 1 & B.AltoPinheir & 1 & J.Boaçava & 1 & Pt.Bandeirant & 1 & Rod.ItapEmG & 1 \\
\hline A.Interlagos & 1 & B.ArturAlvim & 1 & J.Botanico & 1 & Pt.Bresser & 2 & Rod.Mair.Cai & 1 \\
\hline A.Ipiranga & 5 & B.BelaVista & 1 & J.Europa & 1 & Pt.CasaVerde & 4 & Rod.Mair.FrR & 2 \\
\hline A.Itaquera & 2 & B.Cambuci & 2 & J.Gloria & 2 & Pt.Cebolao & 2 & Rod.PrDutra & 3 \\
\hline A.Jabaquara & 2 & B.CampElise & 1 & J.Sto.Elias & 1 & Pt.Cha & 1 & Rod.RapTav & 3 \\
\hline A.Jaguare & 1 & B.Cantareira & 1 & L.Arouche & 2 & Pt.CidUnivers & 4 & Rod.RegisBit & 3 \\
\hline
\end{tabular}

Autor: Antonio Jaschke Machado 
Tabela 5.2 - Continuação.

\begin{tabular}{|c|c|c|c|c|c|c|c|c|c|}
\hline Lugar & Freq. & Lugar & Freq. & Lugar & Freq. & Lugar & Freq. & Lugar & Freq. \\
\hline & & & & & & & & \\
\hline Rod.Romeiro & 1 & R.CardAlmeid & 2 & R.LiberoBada & 2 & R.StaRosa & 2 & Shop.Guarulh & 1 \\
\hline Rod.Roseira & 2 & R.Clelia & 4 & R.LuisGoes & 1 & R.SenQueir & 4 & Shop.MarkPl & 1 \\
\hline R.daAlfandeg & 1 & R.Consolaç & 1 & R.Marq.S.Vic & 11 & R.SilvaBueno & 1 & Tr.Dard.PioXI & 6 \\
\hline R.AlfBovero & 1 & R.Coriolano & 4 & R.MiGasMes & 1 & R.TeodSamp & 2 & Trev.Perus & 2 \\
\hline R.Apiacas & 1 & R.CunhaGago & 2 & R.MouratoCo & 1 & R.Tito & 14 & Trop.Capricor & 1 \\
\hline R.Apinages & 3 & R.Dardanelos & 35 & R.Natingui & 1 & R.13deMaio & 1 & T.Anhangab & 1 \\
\hline R.ArturAzeve & 2 & R.DesVale & 1 & R.NSdaLapa & 10 & R.Turiassu & 2 & T.Ibir.Jabaq & 1 \\
\hline R.Augusta & 1 & R.DMoraes & 2 & R.OscarFreir & 1 & R.daUniao & 1 & T.daMarta & 1 \\
\hline R.BarFunda & 1 & R.Dr.Zurquim & 1 & R.PMachado & 1 & R.VargemCed & 1 & T.MataFria & 2 \\
\hline R.BoaVista & 1 & R.GastaoMes & 2 & R.PaulaSouz & 1 & R.Vergueiro & 5 & T.Olim.Matar & 1 \\
\hline R.Butantã & 3 & R.GBuchard & 1 & R.PedrosoMo & 13 & R.WashiLuis & 1 & T.Paul.DArn & 1 \\
\hline R.Camargo & 1 & R.Groenlandi & 1 & R.PeixGomid & 1 & R.Whitaker & 1 & T.Pç.Roosev & 1 \\
\hline R.CampPiauí & 1 & R.Guaicurus & 2 & R.Pinheiros & 1 & R.XavierTole & 1 & Zona Cereal & 3 \\
\hline R.Canario & 1 & R.IgnacioPRo & 1 & R.PioXI & 30 & R.ZeqAbreu & 2 & Zona Leste & 3 \\
\hline R.Cantareira & 2 & R.Iperoig & 4 & R.Piracuama & 4 & Sambodromo & 1 & Zona Norte & 2 \\
\hline R.CapoteVale & 2 & R.JoaoRamal & 3 & R.P.FabFanu & 1 & SecrAgricult & 1 & & \\
\hline R.CardealArc & 2 & R.doLavapes & 1 & R.Purpurina & 1 & SerraCantarei & 1 & & \\
\hline
\end{tabular}

Autor: Antonio Jaschke Machado

\subsubsection{LOCALIZAÇÃO EM PRIMEIRA APROXIMAÇÃO}

\subsubsection{Uma rede metropolitana}

Em uma primeira aproximação, é apresentada a rede de trajetos realizados com o laboratório móvel, e que efetivamente pode ser georreferenciada de maneira bem-sucedida (Fig. 5.1).

Esta rede é inicialmente localizada em termos das coordenadas astronômicas, mediante sua posição relativa aos limites geopolíticos do município de São Paulo. 


\subsubsection{Adensamento no município}

Nota-se alguns trajetos realizados além deste limite, caracterizando uma investigação que efetivamente considera a região metropolitana do município.

Muitos segmentos que compõem esta rede foram percorridos mais de uma vez, havendo até o momento um adensamento da rede em torno do setor central do município de São Paulo.

\subsubsection{Extremos menos adensados}

Dentre os segmentos de maior extensão, posicionados além do limite municipal, nota-se a oeste o percurso linear até Bom Jesus de Pirapora, enquanto a leste tem-se o percurso circular cujo arco mais oriental inclui os municípios de Ribeirão Pires, Suzano e Itaquaquecetuba.

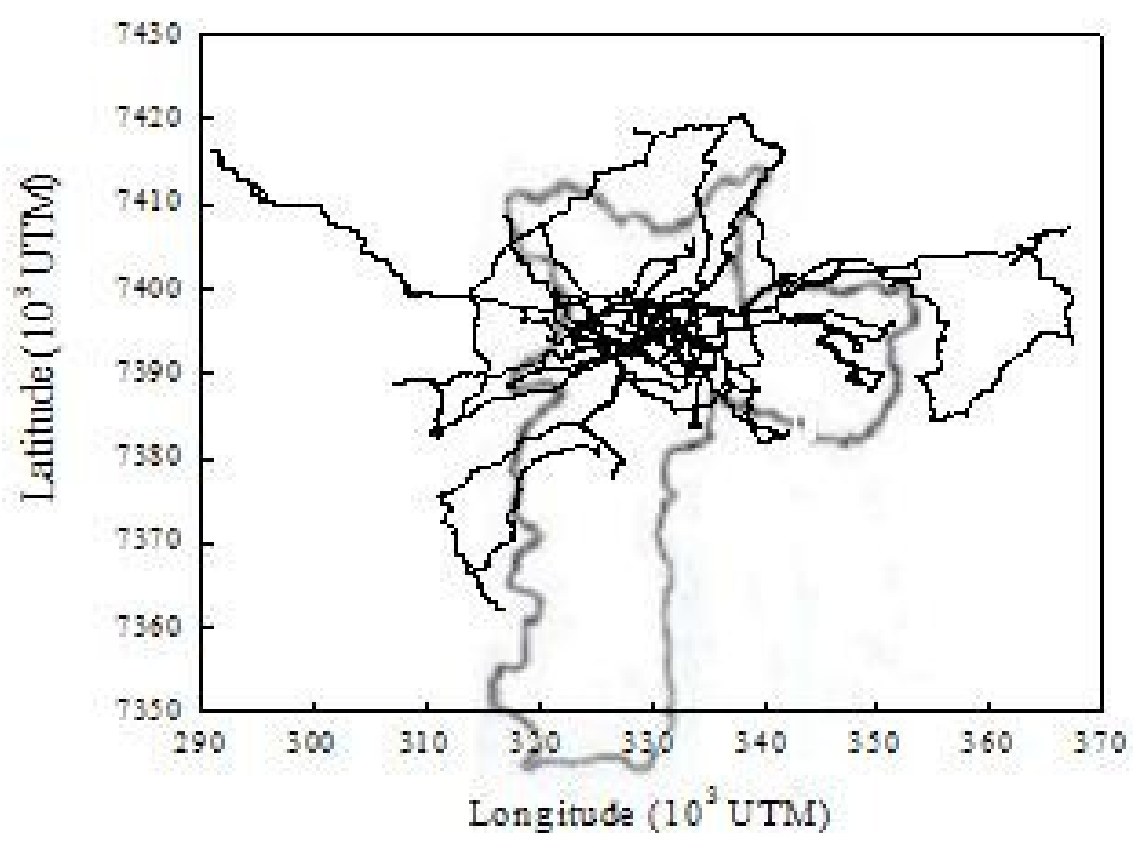

Autor: Antonio Jaschke Machado

Figura 5.1 - Rede de trajetos efetivamente georreferenciados entre 27 de julho de 2006 e 31 de maio de 2007, e sua localização relativa à fronteira geopolítica do município de São Paulo. 


\subsection{Natureza das emissões}

\subsubsection{RESULTADOS EM TRANSETOS}

\subsubsection{Distribuição unidimensional de $\mathbf{L}$}

As trocas de energia por emissão radiativa entre o piso de um percurso e os elementos que compõem sua cobertura podem ser vistas de um modo útil, especialmente no caso da componente recebida próximo ao chão, utilizando-se a analogia térmica (Capítulo 2.3, ítem3).

O fluxo $L^{*}$ é quase sempre negativo para a maioria das superfícies. No entanto, há situações, como sob a presença de vegetação, em que a perda líquida diminui em direção ao chão por causa da redução do fator de visão do céu. Fundamentalmente por este motivo, assim como no caso dos padrões térmicos (Capítulo 2.3, item 2.3.3.2), as observações associados às emissões dos diversos elementos são armazenadas em arquivos que contenham as informações relativas não apenas ao valor médio, mas também aos desvios e sobretudo aos extremos absolutos verificados.

Por outro lado, a intermitência entre fatores diversos de visão do céu, ora com o hemisfério obscurecido ora não, torna definitiva a opção que restringe o intervalo de armazenamento reduzindo-o e fixando-o permanentemente aos 10 segundos. (veja as discussões Capítulo 2.1, item 2.1.1.3; Capítulo 2.3, itens 2.3.3.1 e 2.3.3.2).

\subsubsection{Efeitos múltiplos sobre $L \downarrow$}

O fluxo radiativo vertical em ondas longas entre um sistema piso-vegetação-ar-edificações (tal como na Figura 4.3) pode ser bem compreendido em um transeto específico. Mas a natureza deste fluxo em um volume é menos claro. A partir deste momento os esforços serão concentrados em relação aos balanços radiativos e energéticos (de uma maneira mais ampla) 
do sistema total que constitui a metrópole. Os fluxos horizontais são considerados separadamente, mas também fazem parte do mesmo sistema.

\subsubsection{TOTALIZAÇÃO DOS RESULTADOS}

O perfil bruto dos fluxos radiativos e temperaturas das superfícies remotamente observadas (Fig. 6.1) correspondem àquele para a temperatura do ar, que foi apontado no Capítulo 2.2 (Figura 4.4).

A variabilidade dos dados observados sugere uma distribuição de freqüências (Fig. 6.2) que, à exceção de $\mathrm{Q}^{*}$, parecem assumir características de uma distribuição normalizada.

O saldo em ondas longas apresentado é obtido a partir do segundo canal do pirgeômetro e é resultado do saldo que ocorre sobre a termo-pilha, tendo em vista sua emissão a partir de seu equilíbrio térmico com o corpo do aparelho. Considerando-se o equilíbrio térmico entre o pirgeômetro e o ar que o circunda (para uma discussão mais detalhada ver Capítulo 3.1, item 3.1.4; MACHADO e AZEVEDO, 2006a), para o veículo em movimento, o que se obtem aqui é o saldo em ondas longas para um nível acima e relativamente afastado da superfície asfáltica $\left(\mathrm{L}_{\mathrm{N}}{ }^{*}\right)$. Este nível está posicionado a uma altura correspondente à altura da cobertura do veículo, e é da ordem de 1,5 m. Nota-se que $\mathrm{L}_{\mathrm{N}}{ }^{*}$ apresenta um padrão fundamentalmente negativo, indicando que a base do canyon urbano está em geral mais aquecida do que o conjunto formado pelo céu e as paredes. Percebe-se também que sua magnitude modal corresponde a algo em torno de $70 \mathrm{Wm}^{-2}$.

Apresentando amplitudes positivas com magnitudes máximas muito superiores a $\mathrm{L}_{\mathrm{N}}$, observe-se agora a distribuição para Q*. Esta sobrepujança de intensidade de fluxo é devida na maior parte às observações diurnas sob efeito da radiação solar de incidência direta. Todavia, note-se que a amplitude negativa apesar de bem inferior é da ordem de grandeza da magnitude de $\mathrm{L}_{\mathrm{N}}{ }^{*}$. Isto se deve ao fato de ambas serem aproximadamente coincidentes durante o período noturno. 
É curioso perceber na distribuição de $Q^{*}$, que apesar da evidência de grandes máximos associados a um fluxo positivo de elevada intensidade, o seu valor modal é negativo e de pequena magnitude, correspondendo a algo em torno de $30 \mathrm{Wm}^{-2}$. Este fato parece indicar que de um modo geral, na camada urbana abaixo das coberturas, $Q^{*}$ não funciona exatamente como uma fonte de energia, mas sim como um sumidouro. Ou seja, pensando-se apenas na troca de calor pelos processos radiativos, a camada urbana estaria lentamente resfriando-se por perda radiativa.

Os fluxos radiativos observados são, na realidade, resultado da configuração térmica na metrópole. Em geral, as paredes parecem tender a um equilíbrio térmico com o ar. Porém, isto não é sempre verdade, principalmente nos experimentos realizados durante os dias sob domínio de massas de ar frias e secas. Nesta situação as paredes podem estar consideravelmente mais resfriadas do que o ar, apresentando inclusive valores negativos de temperatura. Do ponto de vista exclusivamente térmico parecem indicar possíveis localidades potenciais para a ocorrência de geadas na metrópole. De todas as formas, observa-se que a amplitude térmica média do ar na metrópole paulistana não ultrapassa o intervalo entre $8^{\circ} \mathrm{C} \mathrm{e}$ $36^{\circ} \mathrm{C}$.

A natureza das propriedades físicas observadas no meio urbano parece estar associada à presença de quatro elementos fundamentais (Fig. 6.3): a atmosfera, as árvores, o asfalto e as superfícies verticais (Capítulo 2.1). Esta associação é de certo modo resultado da forma como ocorre a estruturação e a montagem dos sensores para os experimentos idealizados. 


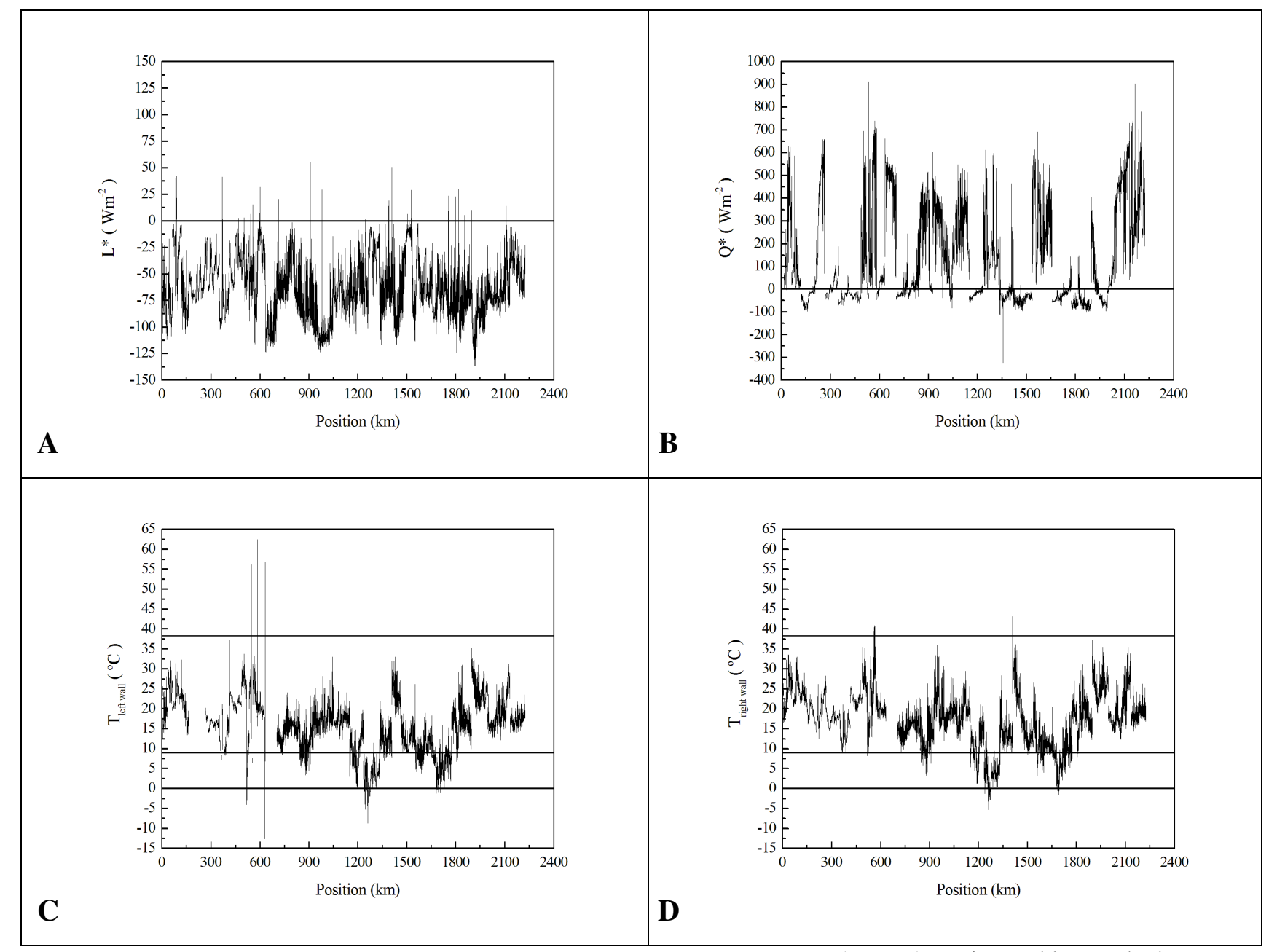

Autor: Antonio Jaschke Machado

Figura 6.1 - Variabilidade espacial, em transeto, das magnitudes amostradas do saldo radiativo em ondas longas verificado sobre o veículo (a), saldo radiativo multiespectral verificado acima da superfície (b), temperatura sobre as superfícies verticais à esquerda do veículo em deslocamento (c) e temperatura sobre as superfícies verticais à direita do veículo em deslocamento (d). 


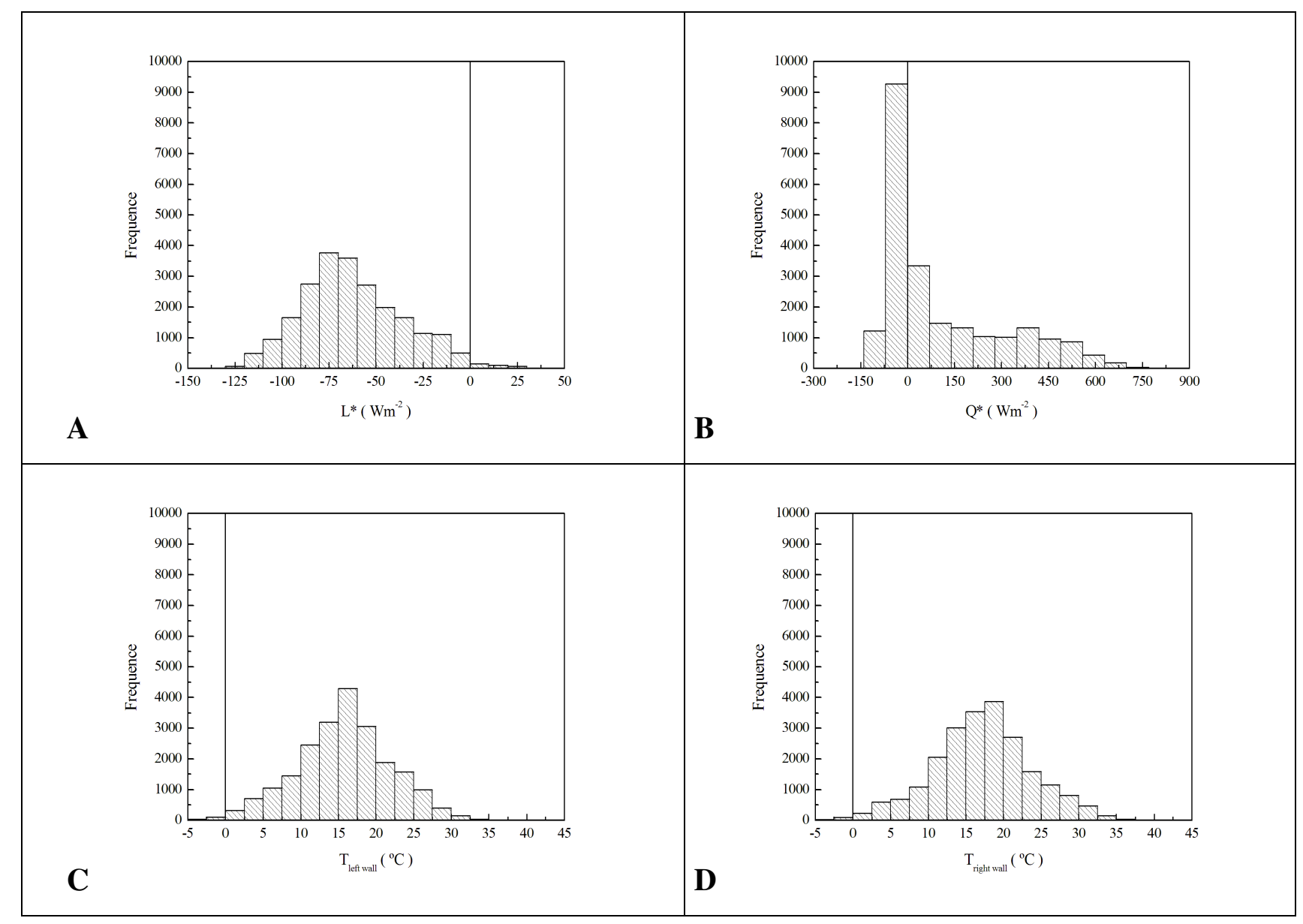

Autor: Antonio Jaschke Machado

Figura 6.2 - Histogramas das magnitudes amostradas do saldo radiativo em ondas longas verificado sobre o veículo (a), saldo radiativo multiespectral verificado acima da superfície (b), temperatura sobre as superfícies verticais à esquerda do veículo em deslocamento (c) e temperatura sobre as superfícies verticais à direita do veículo em deslocamento (d). 


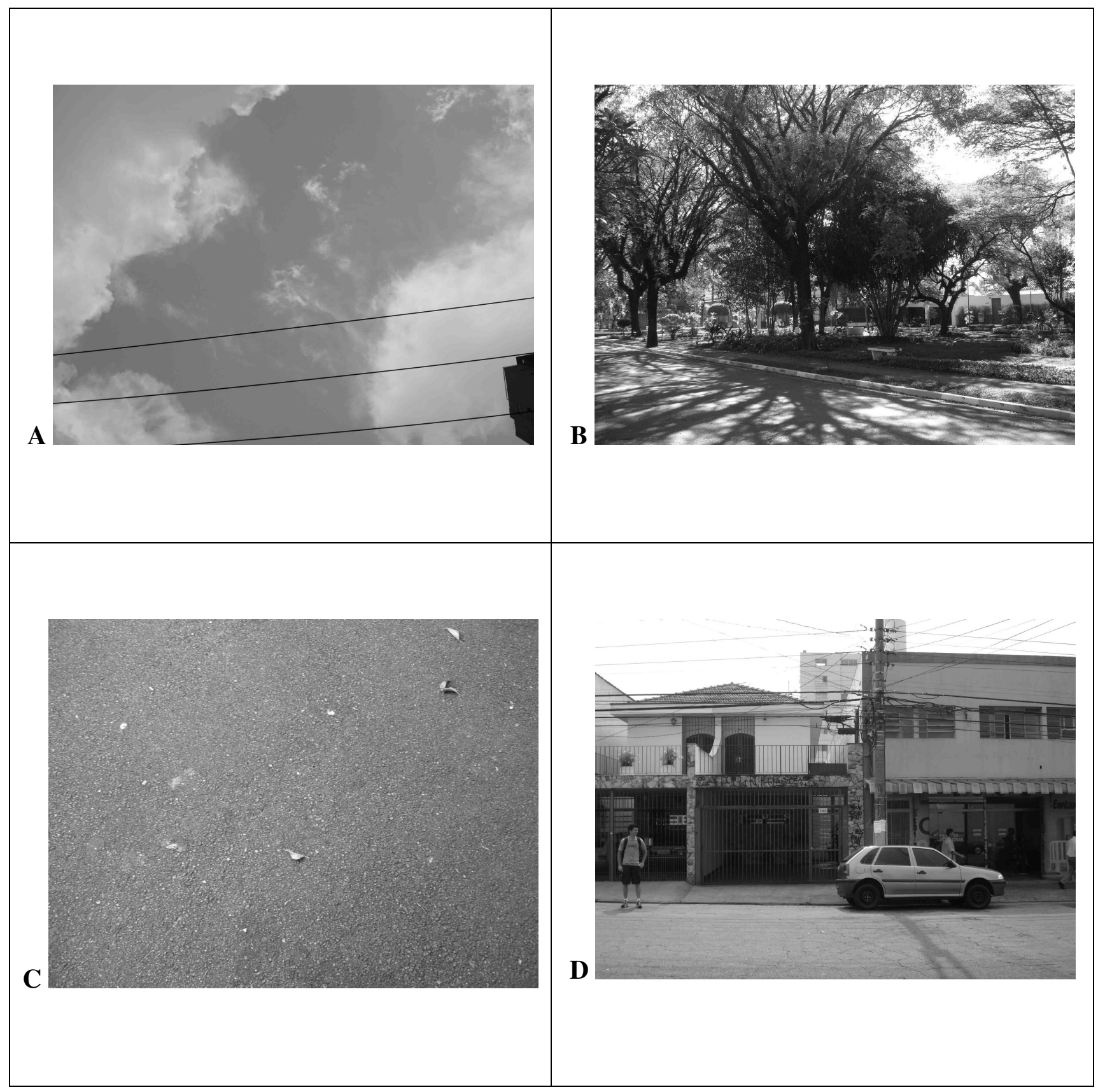

Autor: Antonio Jaschke Machado

Figura 6.3 - Vista do céu na Rua Dardanelos (a), das árvores na Praça John Lennon (b), do asfalto na Rua Sebastião Cortês (c) e das superfícies verticais na Rua Tito (d). 


\subsubsection{Avaliação}

Com o intuito de verificar diretamente os padrões térmicos associados a estes elementos do meio urbano (Fig. 6.4), foi idealizado um conjunto de experimentos fixos. Estes experimentos foram realizados sempre em uma mesma localidade, a Rua Sebastião Cortês na região oeste do município de São Paulo. Foram verificados diferentes horários, desde o amanhecer ao anoitecer, tanto na estação úmida como na estação seca.

A verificação direta da temperatura superficial, por intermédio de termístores, serve fundamentalmente para validar as observações remotas realizadas com os IRTs e radiômetros. Fornecendo-se, assim, uma estimativa das emissividades associadas às paredes revestidas por concreto, às vias asfaltadas, às folhas das árvores e ao ar.

Medindo-se sob duas situações distintas, mediante a maior ou menor exposição ao céu aberto, determina-se sempre um par de padrões térmicos correspondentes. Estes padrões correspondem, respectivamente, às situações com predominância de incidência solar direta ou com predominância de sombreamento pelos diversos elementos urbanos.

Os perfis apresentados na Figura 6.4 são dispostos de maneira semelhante à disposição das Figuras 6.1 e 4.4, sob uma sucessão de experimentos. Todavia, ao invés de uma distribuição espacial, por tratar-se agora de um experimento fixo, o que se tem é a evolução temporal das diversas temperaturas superficiais.

Não foram observados valores que extrapolassem os valores médios da temperatura do ar observada nos experimentos móveis. Percebe-se com isso uma certa desmitificação dos elevados valores de temperatura que poderiam estar associados sobretudo ao asfalto. $\mathrm{O}$ que se nota são constantes padrões de aquecimento e resfriamento que se repetem conforme a sombra das árvores e edifícios se deslocam, mediante a variação do ângulo de elevação do disco solar.

É curioso observar o que se sucede com a vegetação, nos episódios em que a temperatura sob a copa sombreada torna-se superior à temperatura da copa exposta aos raios solares. Neste caso, os valores inferiores na parte superior da copa não estão necessariamente sob o sombreamento de edifícios ou de outras árvores mais altas. Mesmo sob incidência direta dos raios solares, as copas das árvores parecem apresentar um gradiente de temperatura invertido, do topo ensolarado para a base sombreada. Este efeito precisaria ainda ser melhor estudado. Seria uma contribuição da emissão em ondas longas a partir de elementos abaixo das copas, 
ou seria um resultado do chamado "efeito termostato" associado à abertura e fechamento dos estômatos?

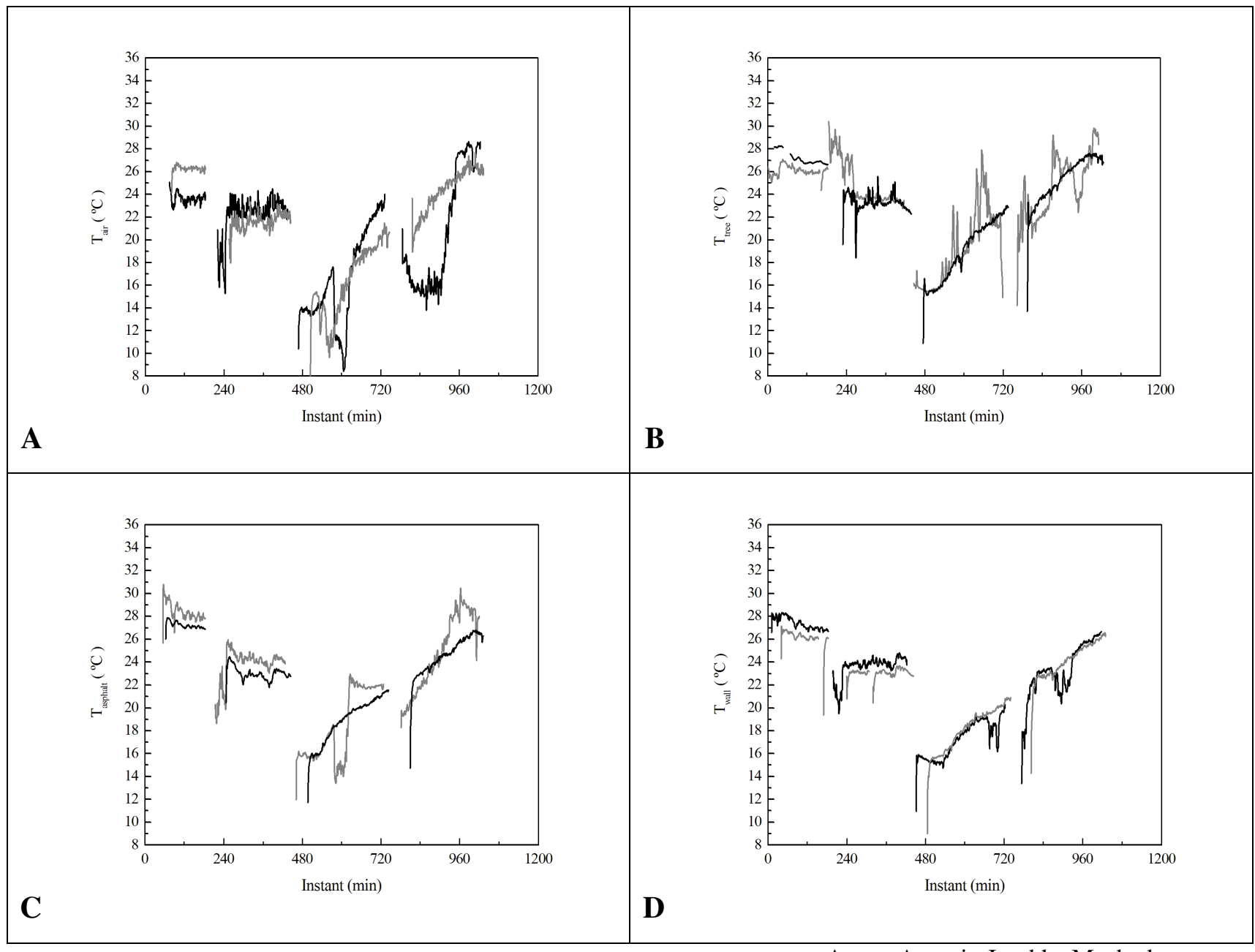

Autor: Antonio Jaschke Machado

Figura 6.4 - Variabilidade temporal das temperaturas, na Rua Sebastião Cortês, do ar (a), das folhas das árvores (b), do asfalto (c) e dos muros (d). As linhas claras indicam superfícies originariamente expostas, enquanto as linhas escuras indicam superfícies originariamente sombreadas. 


\subsubsection{Inferência}

Retornando ao objeto central do trabalho, observa-se agora já ser quase possível a obtenção de uma estimativa mais realista dos fluxos em onda longa no meio urbano.

Antes de mais nada, no entanto, para casos como esse, é preciso estimar o valor efetivo de $\mathrm{L}^{*}$ (Fig. 6.5) para um nível justamente acima da superfície asfáltica. Mais precisamente para algo em torno de 0,3 m acima dela, correspondendo ao nível onde está fixa a proa instalada no veículo, com o saldo-radiômetro acoplado. Para isto, deve-se iniciar estimando o fluxo L $\downarrow$ 1 Convém, portanto, utilizar L*, subtraindo-se deste a emissão da termo-pilha, conforme a lei de Stefan-Boltzman para o corpo negro e a temperatura do ar observada, tendo em vista a condição de equilíbrio térmico.

A partir da estimativa de $\mathrm{L} \downarrow$, pode-se chegar à estimativa da componente $\mathrm{L} \uparrow$, utilizando-se Q* e a temperatura do ar observados e aplicados à parametrização proposta para esta componente (Eq. 1.13). Neste caso, a emissividade considerada para o asfalto é de 0,95 (Arnfield, 1982; Oke, 1987; Arya, 2001).

Tendo-se as duas componentes verticais, a diferença entre elas fornece imediatamente a estimativa de $\mathrm{L}^{*}$ em um nível muito próximo ao asfalto. O padrão de distribuição discutido para $\mathrm{L}_{\mathrm{N}} *$ é muito semelhante ao verificado em $\mathrm{L}^{*}$. É possível notar, talvez, um valor modal um pouco mais intenso para $\mathrm{L}^{*}$, em torno de $75 \mathrm{Wm}^{-2}$. Isto se deve ao fato da cobertura asfáltica estar em geral mais aquecida do que o ar.

Os valores modais verificados para as componentes $\mathrm{L} \downarrow$ e $\mathrm{L} \uparrow$ valem respectivamente algo em torno de 350 e $415 \mathrm{Wm}^{-2}$. Evidenciando que em média a base do canyon urbano está mais aquecida do que o céu e as paredes.

De maneira análoga pode-se estimar a emissão das paredes $\left(\mathrm{L}_{\mathrm{W}}\right)$ através das observações realizadas com os dois IRTs, posicionados tanto à direita como à esquerda do veículo (Fig.6.6). Aplicando-se a lei de Stefan-Boltzmann para um corpo cinza para cada valor observado da temperatura das paredes, e supondo-se uma emissividade média para os alvos laterais em torno de 0,9 (Arnfield, 1982; Oke, 1987; Arya, 2001), apesar da grande

\footnotetext{
${ }^{1}$ Na realidade, esta componente do fluxo foi diretamente observada nos experimentos iniciais, correspondendo ao primeiro canal do pirgeômetro. Porém, o consumo da bateria específica a este uso mostrou-se demasiadamente elevada, além do método não ser o mais preciso.
} 
variabilidade reconhecida de materiais constituintes, obtém-se valores modais em torno de 370 e $350 \mathrm{Wm}^{-2}$, para os alvos à direita e à esquerda, respectivamente.

Esta diferença entre os valores médios gerais não reflete ainda as diferenças que resultariam das distintas orientações das paredes em relação à posição do disco solar. Eles devem-se sobretudo ao posicionamento do veículo perante o sentido de direção relativo ao trânsito. Assim sendo, há em geral uma menor distância entre o sensor e os alvos à direita, o que constituiria valores mais realistas. Os alvos à esquerda podem, em diversas situações, estar posicionados demasiadamente distantes do sensor. O sinal associado a estes últimos estaria contaminado por uma excessiva divergência de fluxo, o que implicaria em valores reduzidos para a temperatura aparente estimada. 


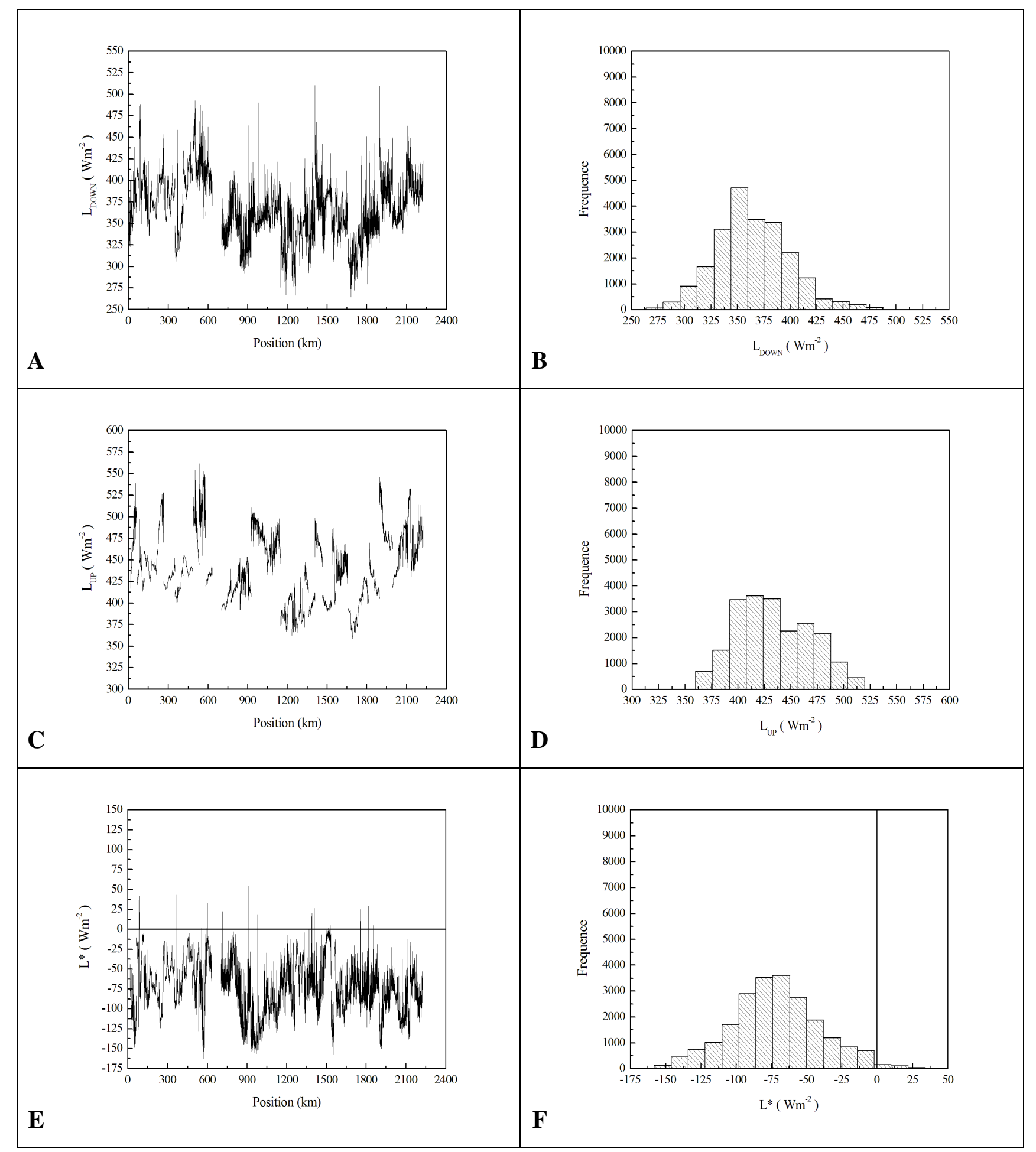

Autor: Antonio Jaschke Machado

Figura 6.5 - Variabilidade espacial, em transeto, das magnitudes estimadas e da respectiva distribuição de frequiências do fluxo incidente (a, b), do fluxo emitido (c, d) e do saldo radiativo em ondas longas (e, f) sobre a superfície do piso urbano. 


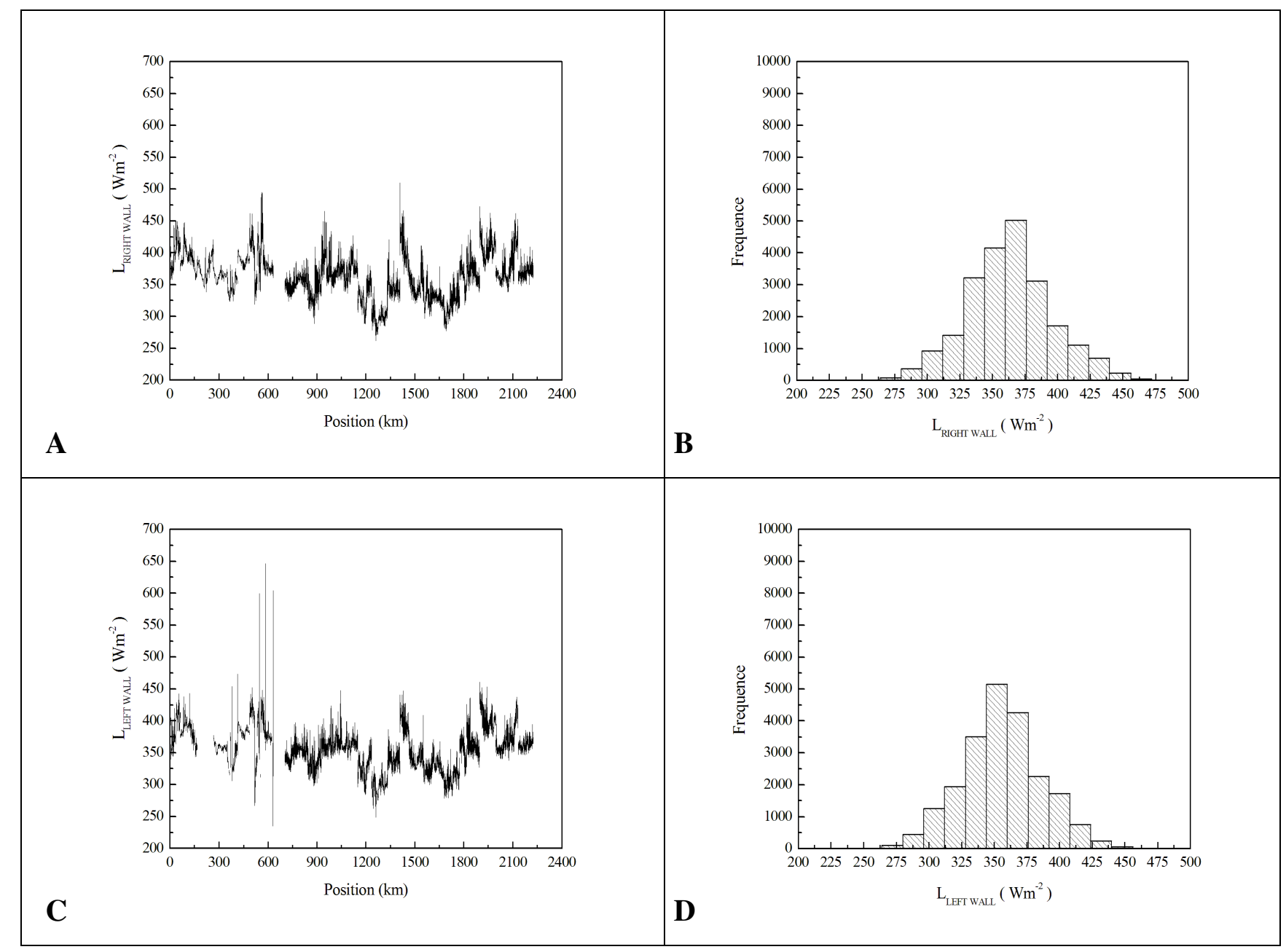

Autor: Antonio Jaschke Machado

Figura 6.6 - Variabilidade espacial, em transeto, das magnitudes estimadas e da respectiva distribuição de freqüências do fluxo emitido pelas paredes à direita do veículo em deslocamento $(\mathrm{a}, \mathrm{b})$ e do fluxo emitido pelas paredes à esquerda $(\mathrm{c}, \mathrm{d})$, em ondas longas.

Portanto, para um indivíduo que se desloca pelas ruas de uma cidade, em termos médios gerais, há um fluxo resultante em ondas longas incidindo sobre ele (Fig. 6.7). Este fluxo deve ser sentido principalmente pelos indivíduos cujos corpos ainda não atingiram o equilíbrio térmico com o meio urbano, e em geral é normalmente desprezado nas situações em que haja incidência direta dos raios solares.

De uma forma geral, trata-se de um fluxo com magnitude ligeiramente superior à $\mathrm{L}^{*}$, e sua direção de incidência não corresponde exatamente à normal em relação à superfície. Realmente, trata-se de um fluxo resultante entre $\mathrm{L}^{*}\left(\sim 70 \mathrm{Wm}^{-2}\right)$ e o saldo observado entre as laterais do canyon $\left(\mathrm{LW}_{\mathrm{W}}^{*}=\sim 20 \mathrm{Wm}^{-2}\right)$. Resultando, assim, em ângulo de incidência da ordem de $15^{\circ}$ em relação à normal, e dirigido para o eixo longitudinal do canyon urbano. 


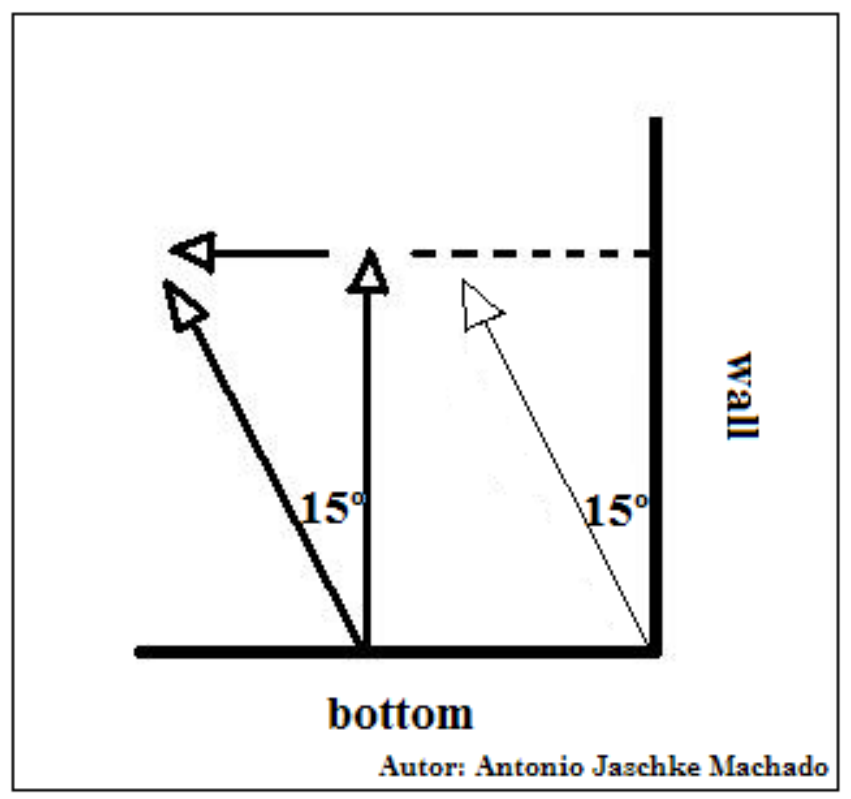

Figura 6.7 - Representação geométrica do fluxo radiativo resultante em ondas longas, sentido por um indivíduo deslocando-se no interior de um canyon urbano.

Desenvolvidas estas idéias fundamentais, resta agora concluir com a verificação das emissividades que foram utilizadas nas estimativas de $\mathrm{L} \uparrow \mathrm{e} \mathrm{L}_{\mathrm{W}}$.

Como se trata da determinação de valores genéricos, a princípio, seja para o asfalto, seja para as paredes, que, na realidade, são constituídas por uma imensa variedade de materiais (concreto, pedra, tijolos, madeira, placas metálicas), contando-se inclusive com seres humanos em vias com grande concentração de pedestres, procede-se à análise da distribuição de freqüências para as temperaturas observadas diretamente sobre a parede e a cobertura asfáltica nos experimentos fixos (Fig. 6.8).

Neste caso, parece haver uma distribuição normal associada, porém, de maneira ainda não conclusiva. Há indícios de um segundo, ou até um terceiro máximo acompanhando o valor modal. Este fato deve-se provavelmente à realização menos exaustiva dos experimentos fixos.

De todo modo, são assumidos os valores modais para o asfalto (em torno de $22,5^{\circ} \mathrm{C}$ ) e a parede (em torno de $23^{\circ} \mathrm{C}$ ). Apesar da amplitude térmica para a base do canyon ser superior (cerca de $20^{\circ} \mathrm{C}$ ) àquela observada para a parede (cerca de $15^{\circ} \mathrm{C}$ ), este resultado parece indicar para o significante fato de que a base dos canyons sofre, muitas vezes, o efeito de 
sombreamento das paredes que podem permanecer ainda sob incidência direta dos raios solares. Mesmo que sob um ângulo de incidência reduzido.

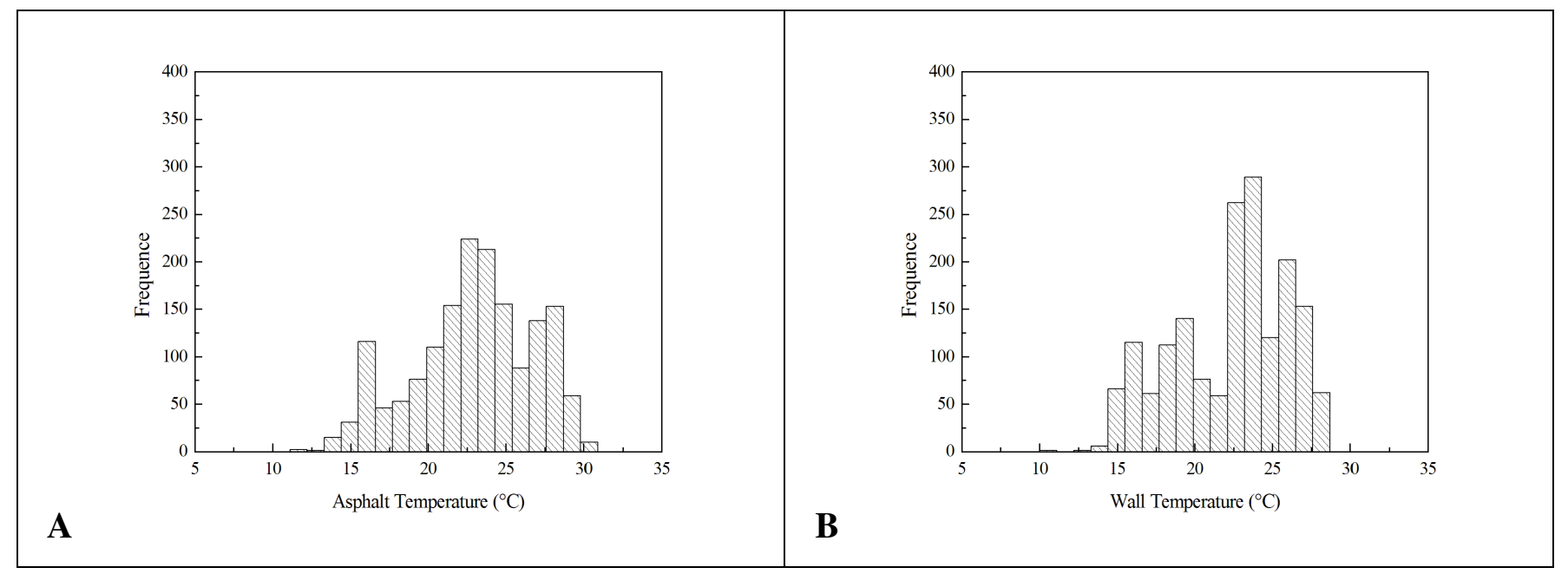

Autor: Antonio Jaschke Machado

Figura 6.8 - Histogramas das magnitudes amostradas da temperatura da cobertura asfáltica (a) e da temperatura da parede (b), verificadas na Rua Sebastião Cortês, Zona Oeste do município de São Paulo.

\subsubsection{Emissividade}

Aplicando-se, enfim, a lei de Stefan-Boltzmann para um corpo cinza, entre estas temperaturas médias observadas nos experimentos fixos e aqueles valores médios estimados para os fluxos em ondas longas nos experimentos móveis, obtém-se as estimativas médias da emissividade asfáltica e das paredes para a metrópole paulistana (Tab. 6.1).

A emissividade encontrada para as ruas de São Paulo, em geral cobertas por asfalto, porém, em alguns casos com cobertura de concreto (como no caso do Rodoanel ou de alguns viadutos) é de algo em torno de 0,96. Enquanto para as paredes, aqui se inclui toda a generalização de materiais encontrados, é algo em torno de 0,84 .

Ao se comparar estes resultados com aqueles aplicados a partir dos valores encontrados na literatura, é possível notar uma boa concordância para o caso das ruas cobertas por asfalto. Nesta situação o erro relativo mediante os valores aplicados no cálculo de L* corresponde a uma subestimativa em torno de $1 \%$. 
No caso da emissividade das paredes, a situação parece ser oposta. Identifica-se uma superestimativa da ordem de $7 \%$. Aqui a questão não é apenas o fato da variabilidade de materiais poder influenciar nos resultados, mas também o fato de ter-se utilizado o limite superior das estimativas encontradas na literatura para as paredes $(0,9)$. Reconhece-se (Arnfield, 1982; Oke, 1987; Arya, 2001) que a emissividade das paredes possui amplitude maior, e seu valor mínimo poderia oscilar entre 0,86 e 0,88. Caso valores desta magnitude tivessem sido aplicados na estimativa de $\mathrm{L}_{\mathrm{W}}$, o erro relativo evidentemente seria inferior.

Tabela 6.1 - Emissividades estimadas e observadas.

\begin{tabular}{|c|c|c|c|c|c|}
\hline $\begin{array}{c}\text { Tipos de } \\
\text { superfície }\end{array}$ & $\begin{array}{c}\text { Fluxo modal } \\
\text { observado } \\
(\mathrm{L} \uparrow)\end{array}$ & $\begin{array}{c}\text { Temperatura } \\
\text { modal } \\
\text { observada }\end{array}$ & $\begin{array}{c}\text { Emissividade } \\
\text { estimada } \\
\text { (Arnfield, 1982; } \\
\text { Arya, 2001) }\end{array}$ & $\begin{array}{c}\text { Emissividade } \\
\text { observada }\end{array}$ & $\begin{array}{c}\text { Erro relativo } \\
\text { da estimativa }\end{array}$ \\
\hline $\begin{array}{c}\text { Cobertura } \\
\text { asfáltica }\end{array}$ & $415 \mathrm{Wm}^{-2}(\mathrm{~L} \uparrow)$ & $22,5^{\circ} \mathrm{C}$ & 0,95 & 0,96 & $-1 \%$ \\
\hline $\begin{array}{c}\text { Paredes } \\
\text { urbanas }\end{array}$ & $370 \mathrm{Wm}^{-2}\left(\mathrm{~L}_{\mathrm{W}}\right)$ & $23,5^{\circ} \mathrm{C}$ & 0,90 & 0,84 & $+7 \%$ \\
\hline
\end{tabular}

Autor: Antonio Jaschke Machado

É muito interessante ainda notar que o método experimental desenvolvido aqui apresenta uma semelhança muito grande ao método de Gauss para solução de equações transcendentais.

No procedimento idealizado por Gauss, a solução não é precisamente exata. Porém, sempre associada a um erro, que pode ser tão inferior quanto maior o número de iterações que sejam executadas em uma via convergente. Aqui, do mesmo modo, temperatura e fluxo em ondas longas se relacionam mediante a lei de Stefan-Boltzman, tendo-se como parâmetro do erro as estimativas da emissividade das superfícies observadas.

Finalmente, deve-se assumir que foi realizado um grande esforço em localizar as magnitudes dos fluxos em ondas longas em algumas de suas componentes principais, especificamente em 
termos da localização astronômica sobre a região da metrópole e de sua representação nos canyons urbanos.

Este processo de localização dos fluxos deve agora se aprofundar em termos mais amplos das relações geográficas, seja pela variabilidade microclimática em São Paulo, seja pela tipologia da ocupação do solo, seja pelo ritmo das atividades humanas.

Somente desta maneira poderá dar-se prosseguimento à próxima etapa do trabalho, que deve discutir principalmente a distribuição destes fluxos sobre a região metropolitana.

Feita a localização dos fluxos em transetos, e a assimilação e ordenamento deste dados, é possível proceder a uma análise objetiva mais complexa, que vise reconhecer a distribuição não mais com um caráter meramente bidimensional, mas também tridimensional.

Neste caso, tendo-se a área da metrópole como domínio, será viável avaliar a distribuição dos fluxos como um plano de informação. De tal modo que este plano poderá ser relacionado a outros, buscando-se reconhecer os modos de interação dos fluxos em ondas longas com outras propriedades geográficas da metrópole.

\subsubsection{NATUREZA DA CIDADE}

\subsubsection{Métodos alternativos}

O desenvolvimento e implementação de equipamentos e instrumental para mensuração de parâmetros ambientais, como o novo dispositivo de anel de sombreamento (OLIVEIRA et alii, 2002b) utilizado para medir a radiação solar difusa em superfície, ou os minirregistradores (AZEVEDO e TARIFA, 2002), é sempre interessante, pois pode gerar alternativas de mais baixo custo e de mais fácil aplicação, inclusive em aferições no meio urbano, como nestes casos apresentados.

Além de observações em pontos fixos, observações em bases móveis também podem ser úteis em situações que não haja quantidade de equipamentos suficientes para se fazer um 
levantamento espacial adequado (VOOGT e OKE, 1998 b; MACHADO e AZEVEDO, 2004; 2005).

Todo o universo conceitual de modelos gerados pelos diferentes métodos de mensuração e análise pode ser reunido em sistemas de processamento geral da informação geográfica, como é o caso do SPRING (INPE, 1999), em que diferentes geo-campos (mapa temático, imagem de sensor remoto ou modelo numérico de terreno) e geo-objetos (mapas cadastrais ou mapas de redes) podem ser agrupados dando origem a diferentes planos de informação e enriquecendo cada vez mais as informações acumuladas e disponíveis no banco de dados.

\subsubsection{Formas}

As formas urbanas merecem ser consideradas em estudos de avaliação do fluxo radiativo em ondas longas, na camada abaixo das coberturas. Há evidências suficientes (BARRING, 1985; MACHADO e AZEVEDO, 2006a) que levam a crer que as temperaturas observadas proximamente à superfície são consideravelmente mais influenciadas pela configuração do céu em uma determinada área, do que a temperatura do ar que venha a ser observada em níveis gradativamente mais elevados. 
3. Análise modificada pela reflexão 


\subsection{Distribuição das emissões}

\subsubsection{ANÁLISE EM MESOESCALA}

\subsubsection{Controle turbulento}

“A concentração de material particulado inalável (na Grande São Paulo, Fig. 7.1) depende essencialmente da densidade e volume de veículos em circulação. Mais por resuspender (...) o particulado acumulado junto às superfícies (...), do que pela produção efetiva.” (AZEVEDO, 2004, p. 85).

Além da turbulência de natureza mecânica, este trabalho busca chamar à atenção a relevância da turbulência de natureza térmica (convectiva), como agente também importante nos processos que determinam as condições microclimáticas próximas ao chão (STULL, 1988; GEIGER et alii, 2003).

\subsubsection{Fluxo divergente}

A partir de uma malha de $2.200 \mathrm{~km}$ de transetos móveis realizados na área metropolitana, e da rede telemétrica fixa da CETESB, são obtidas as distribuições espaciais de $V_{M}$ e $-\nabla_{h} \cdot L^{*}$ (Figs. 7.2 a 7.8 e Eq. 7.1), bem como dos poluentes (Capítulo 3.1, item 2) em termos de coordenadas esféricas (longitude, $\theta$ e latitude, $\lambda$ ), interpolando-se pelo inverso da distância quadrática entre os pontos amostrados e os nós da malha regular do domínio (Fig.7.1).

Como a distância entre $E L$ e $K Z$ é da ordem de grandeza de $1 \mathrm{~m}$ e assume-se $L \downarrow$ constante nesta camada, pode-se aproximar $-\nabla_{h} \cdot L^{*}$ ao gradiente de $L \uparrow$ aplicando-se o sistema internacional de unidades (S.I.): 
$-\nabla_{h} \cdot L *(\theta, \lambda)=-\frac{\partial L *(\theta, \lambda)}{\partial z} \cong L \uparrow_{E L}(\theta, \lambda)-L \uparrow_{K Z}(\theta, \lambda)$

\subsubsection{Distribuição tridimensional}

O experimento móvel, devido à disposição dos sensores, apresenta a possibilidade de estimativa de $L^{*}$ em dois níveis distintos com uma importante particularidade. O sensor disposto no nível inferior $(K Z)$ sofre a influência direta do efeito térmico da superfície do chão. Enquanto o sensor disposto acima do veículo $(E L)$, sobre uma base branca de madeira, torna-se alheio a este efeito, ficando sujeito à condição térmica do ar, sobretudo nos episódios de deslocamento com efeito induzido da ventilação (ver a discussão detalhada em MACHADO e AZEVEDO, 2006a). Por outro lado, em relação à superfície acima, composta pela atmosfera e elementos do meio (edificações e árvores), ambos os sensores sofrem praticamente o mesmo efeito. Pois, a distância entre eles é muito menor do que a distância entre ambos e as fontes radiométricas acima. Estes aspectos tornam o divergente vertical $-\nabla_{h} \cdot L^{*}$, obtido por esta disposição, basicamente um indicador do módulo gradiente de temperatura de dois níveis, entre o chão e o ar a uma altura muito próxima àquela dos abrigos das estações fixas.

Todos os valores numéricos representam médias calculadas sobre todo o conjunto de experimentos realizados, nunca segmentadas por intervalos de tempo. Apenas segmentadas por áreas nas comparações com as estações fixas. Isto é possível pelo grande número de amostragens com uma mesma configuração experimental, sob diversas condições (STULL,1988, p. 35). 


\subsubsection{Estabilidade vertical}

A distribuição espacial de $-\nabla_{h} \cdot L^{*}$ (Fig. 7.7) apresenta uma grande área clara de valores negativos bastante elevados sobre os setores nordeste e leste ao redor da mancha urbana, associados à cobertura vegetal. Um núcleo mais intenso ocorre no setor nortenordeste, justamente no território abrangido pela serra da Cantareira e pela Mata Fria. Estes resultados indicam que os locais mais propícios para o alavancamento do desenvolvimento convectivo a partir do chão, definidos pela maior instabilização do ar, são aqueles com adensamento arbóreo permeados por trechos impermeabilizados. Ou seja, a cobertura asfáltica - ou outros elementos artificiais - cercada por vegetação implica um gradiente vertical mais intenso da temperatura. O chão torna-se mais aquecido, enquanto o ar permanece com temperatura amena.

Um núcleo secundário bem definido também é evidente no centro do domínio investigado (Fig. 7.7). Observe-se que este núcleo não representa exatamente a área central do município de São Paulo, mas uma área mais abrangente que se extende desde o Morumbi até o Ipiranga no eixo oeste-leste, e desde o Pacaembu até o Brooklin no eixo norte-sul, com centro geométrico próximo ao Parque do Ibirapuera. O centro da cidade está a nordeste, no setor com valores nulos de $-\nabla_{h} \cdot L^{*}$. Este resultado corrobora a justificativa física do parágrafo anterior. Pois a área correspondente a este núcleo secundário é planificada sob os princípios da "cidade jardim", com maior adensamento de árvores e parques permeando as edificações. 


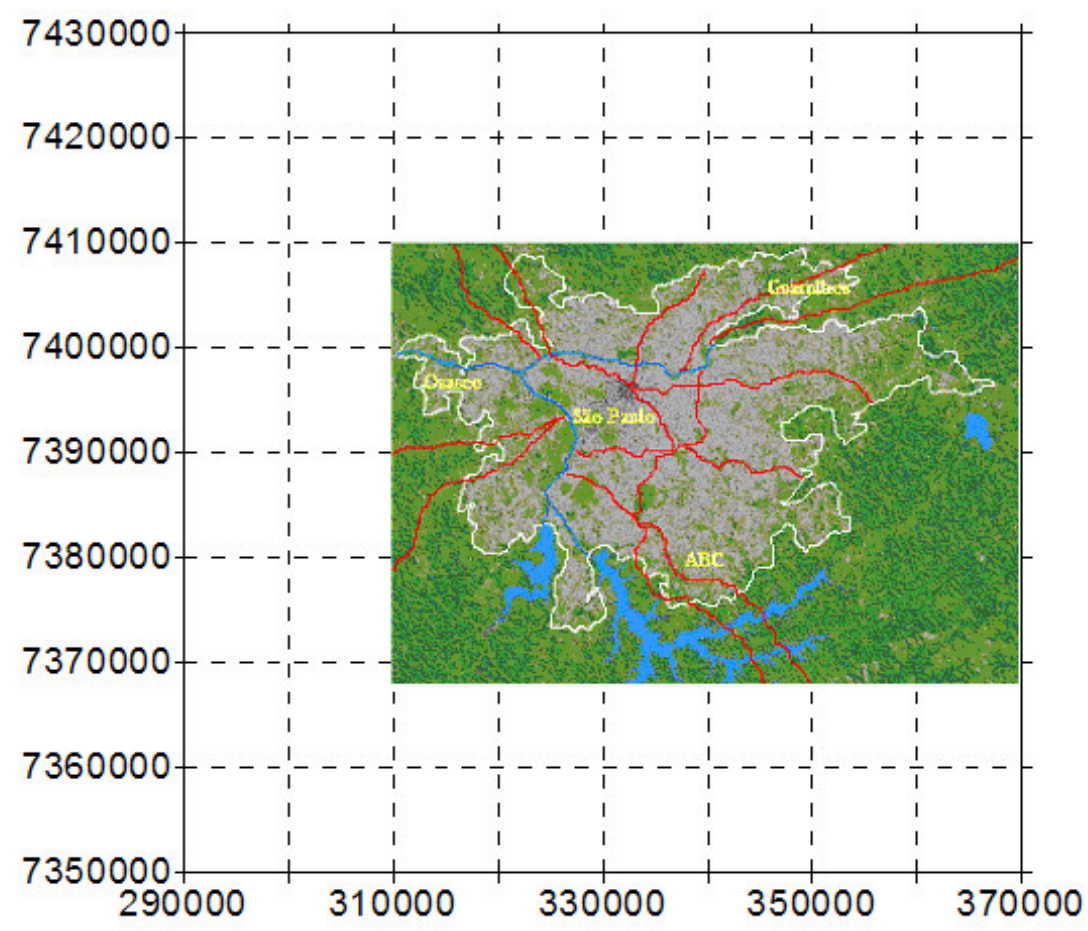

Autor: Antonio Jaschke Machado

Figura 7.1 - Domínio principal em coordenadas UTM, com a localização da mancha urbana principal da metrópole paulistana definida pela análise preliminar do fluxo $\mathrm{Q}^{*}$. Este domínio corresponde a um quadrado com lados medindo $80 \mathrm{~km}$ (ver item 3b, Figura 7.23). 


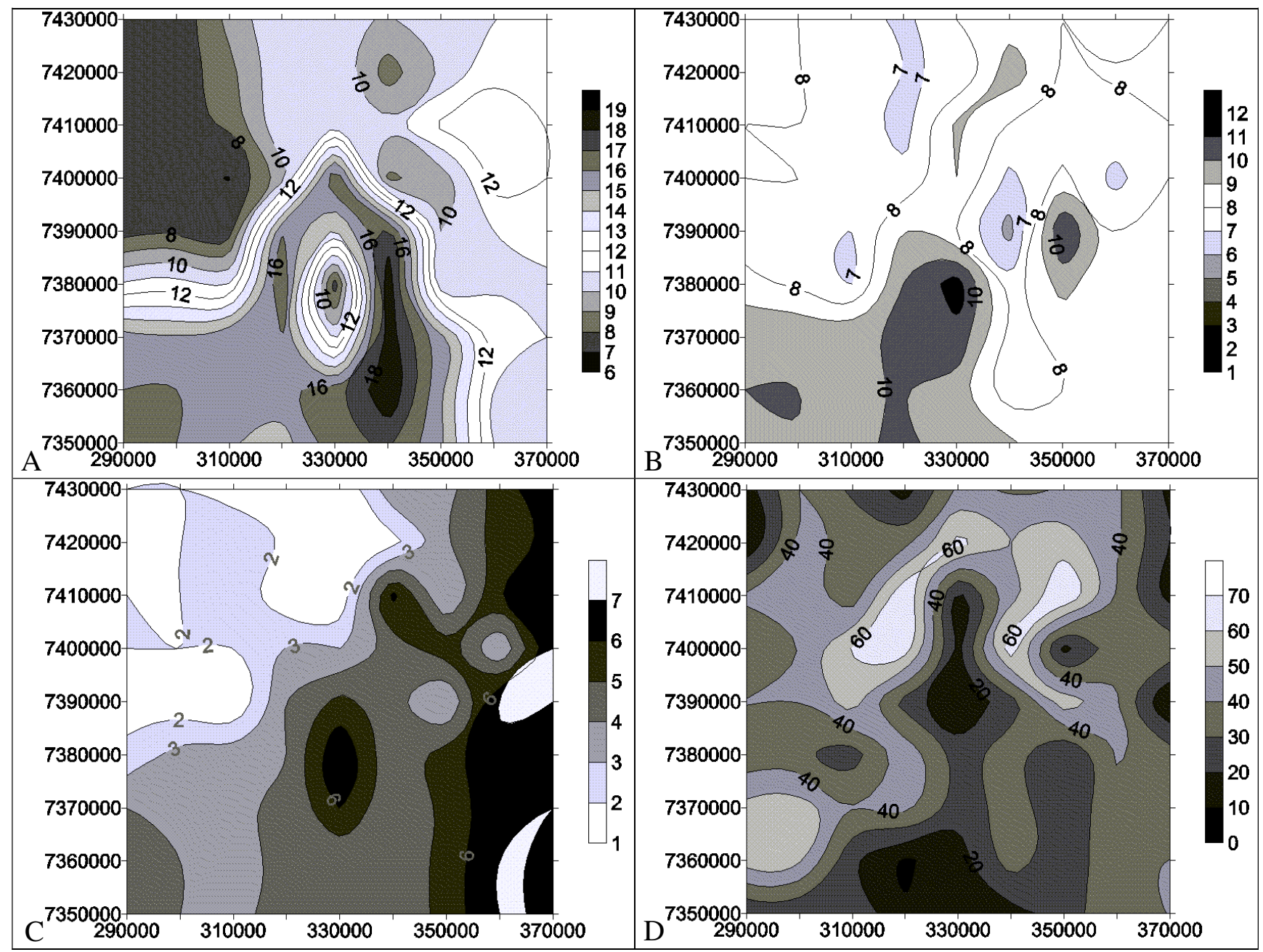

Autor: Antonio Jaschke Machado

Figura 7.2 - Distribuição espacial da hora local (a), do mês (b) e do dia da semana (c) em que foram realizadas as observações. Também é apresentada a distribuição espacial da velocidade média ${\mathrm{em} \mathrm{kmh}^{-1}}^{(\mathrm{d})}$ desenvolvida durante a aquisição dos dados. 


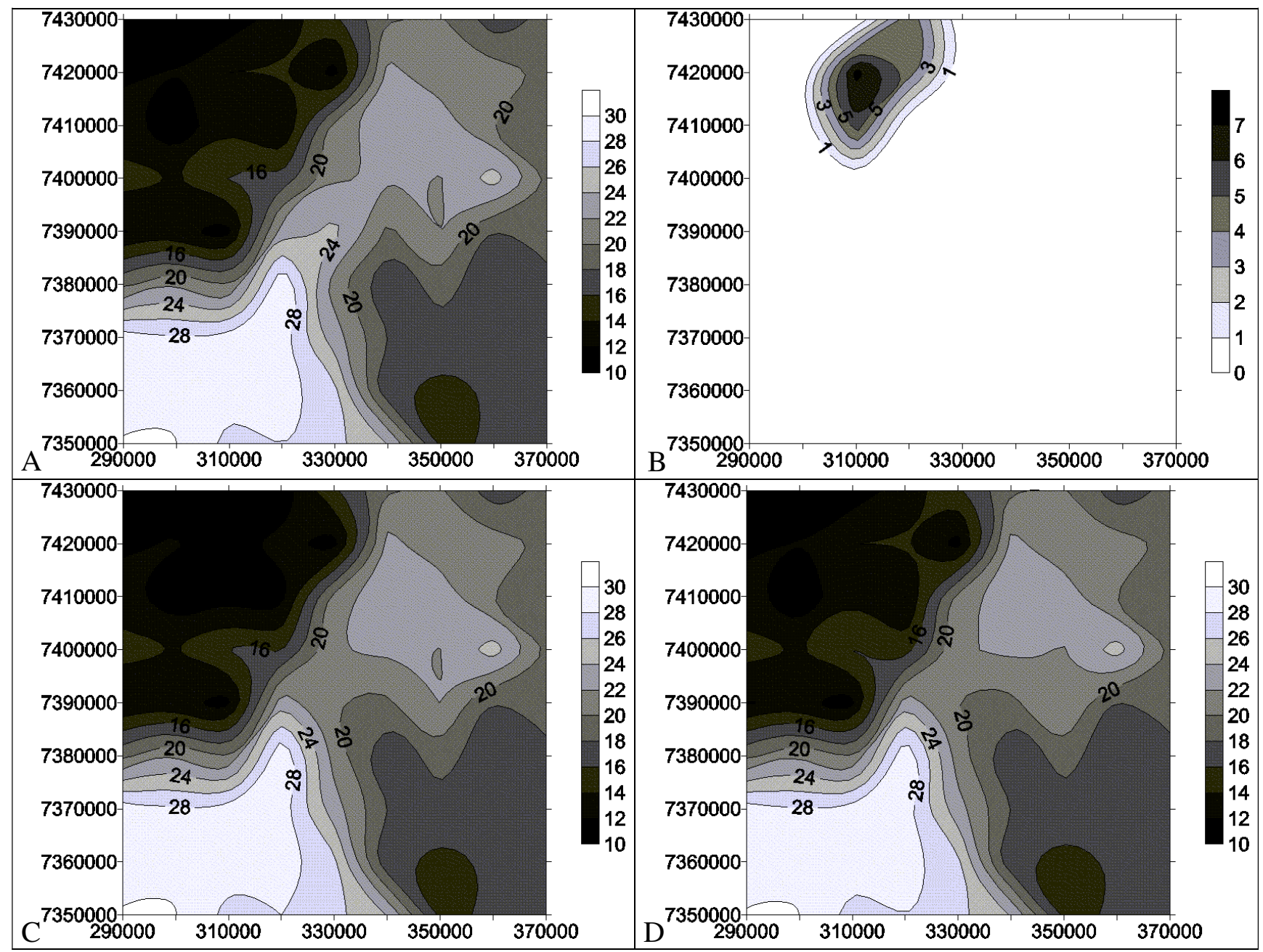

Autor: Antonio Jaschke Machado

Figura 7.3 - Distribuição espacial da temperatura média do ar em ${ }^{\circ} \mathrm{C}$ (a), do desvio padrão (b) e dos valores máximos (c) e mínimos (d) observados em cada intervalo de amostragem. 


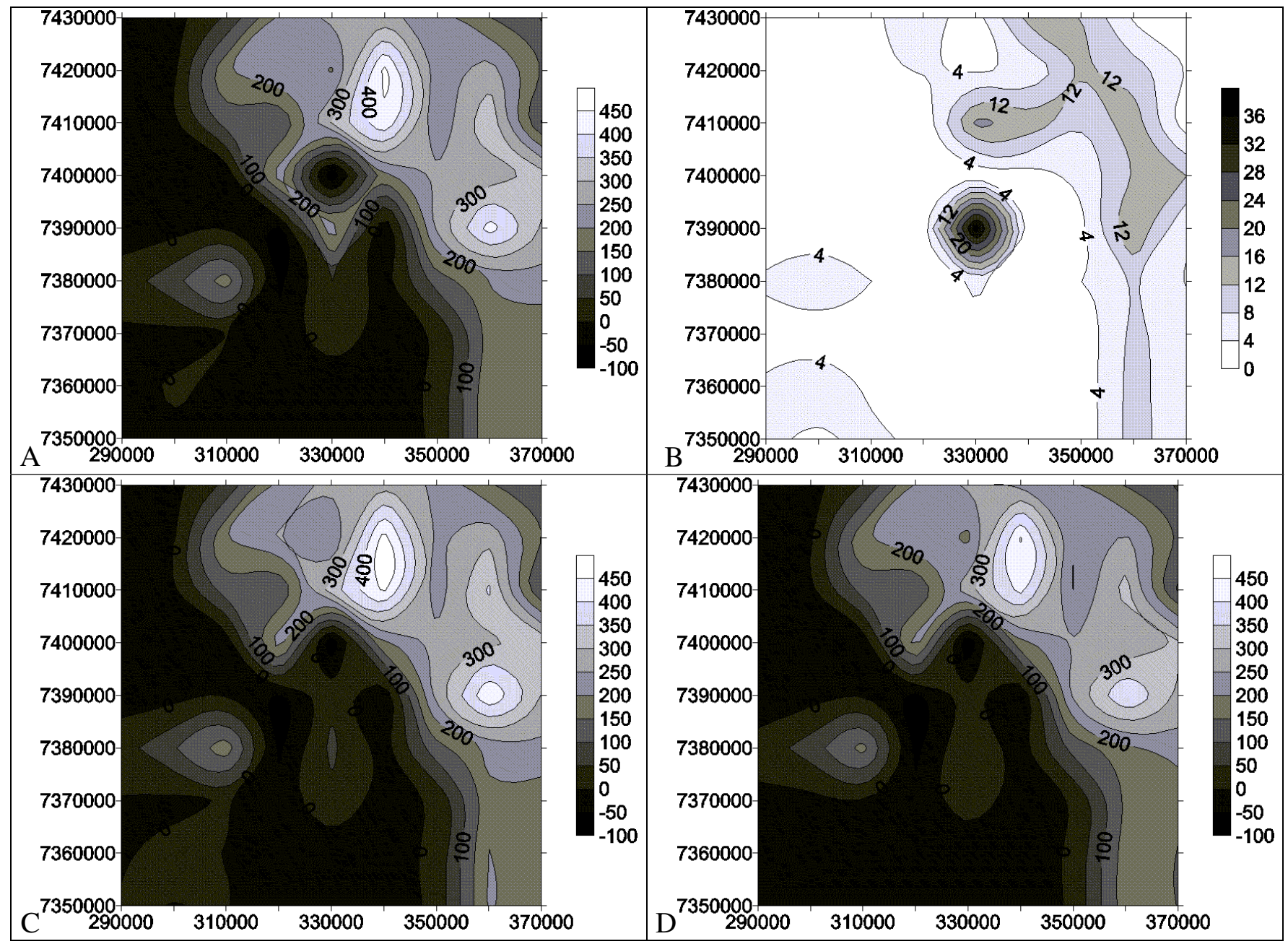

Autor: Antonio Jaschke Machado

Figura 7.4 - Distribuição espacial do fluxo $\mathrm{Q}^{*}$ médio em $\mathrm{Wm}^{-2}$ (a), do desvio padrão (b) e dos valores máximos (c) e mínimos (d) observados em cada intervalo de amostragem. 


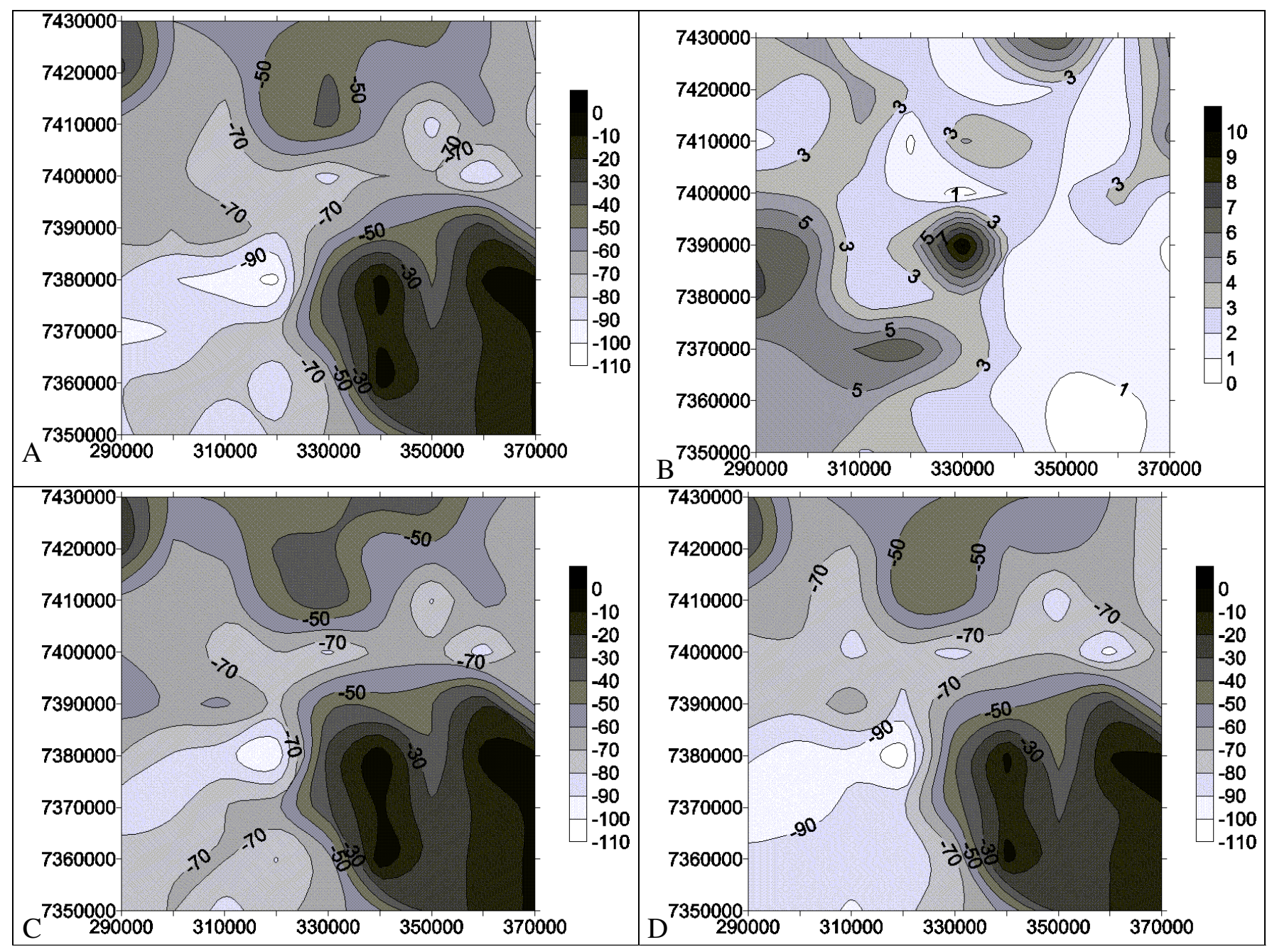

Autor: Antonio Jaschke Machado

Figura 7.5 - Distribuição espacial do fluxo $\mathrm{L}^{*}$ médio em $\mathrm{Wm}^{-2}$ (a), do desvio padrão (b) e dos valores máximos (c) e mínimos (d) observados com o pirgeômetro em cada intervalo de amostragem. 


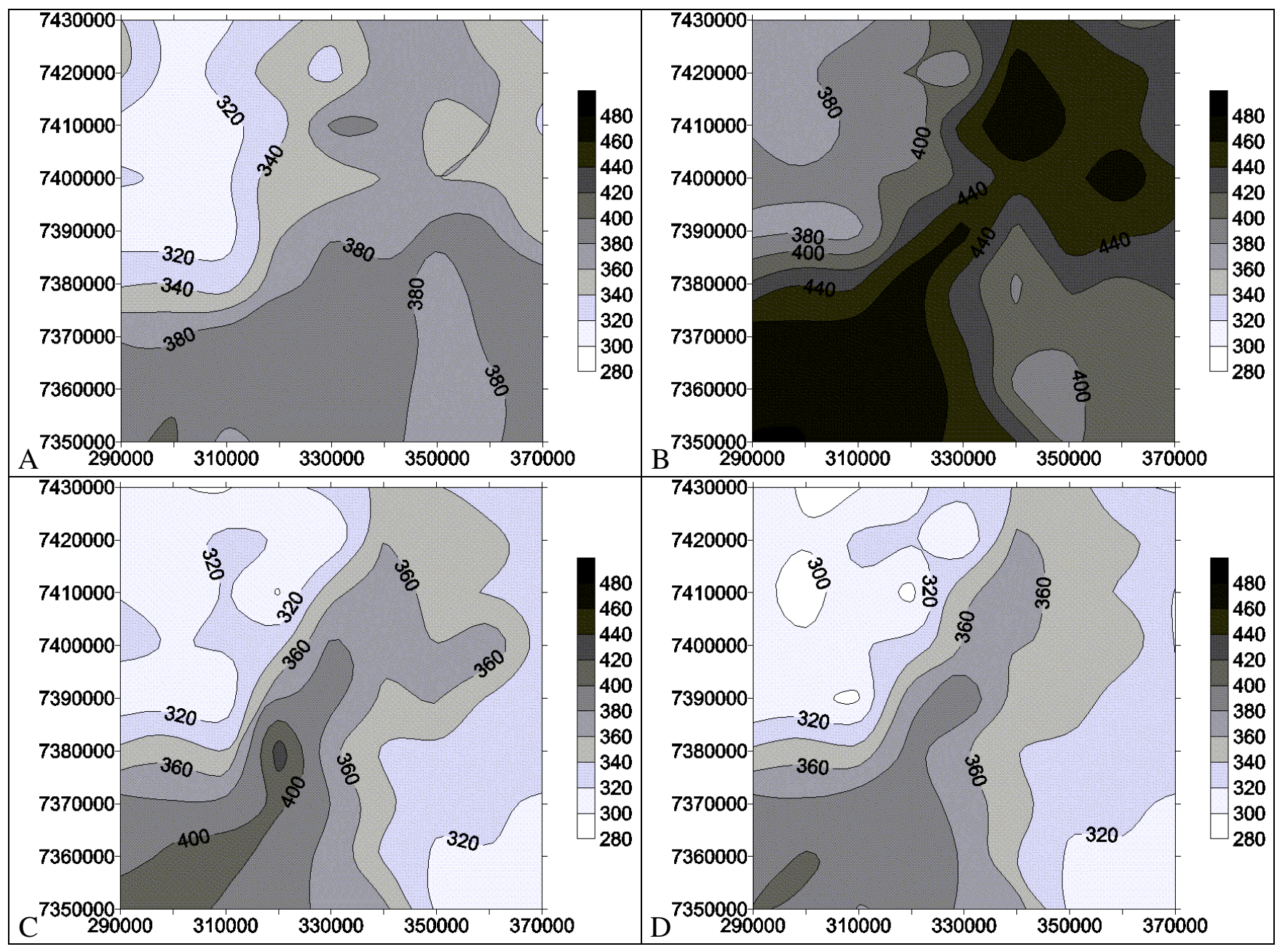

Autor: Antonio Jaschke Machado

Figura 7.6 - Distribuição espacial dos fluxos L $\downarrow$ médio (a), L $\uparrow$ (b), e dos fluxos estimados $\mathrm{L} \rightarrow$ (c) e $\leftarrow$ L (d) emitidos pelas paredes dos canyons, em $\mathrm{Wm}^{-2}$ para cada intervalo de amostragem. 


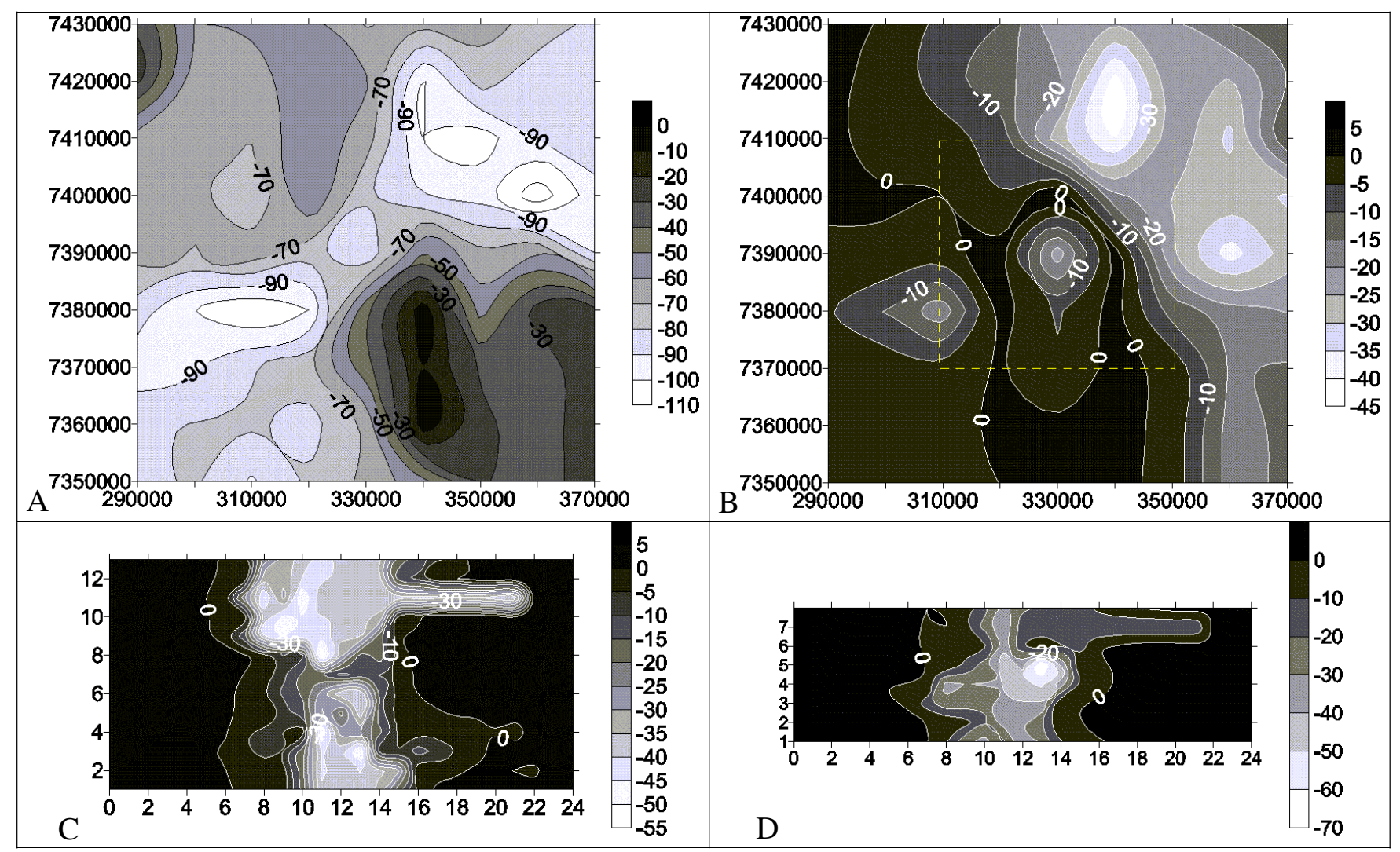

Autor: Antonio Jaschke Machado

Figura 7.7 - Distribuição espacial do fluxo L* estimado no nível do pirradiômetro (a) e da divergência vertical $-\nabla \cdot L^{*}$ estimada na camada próxima ao chão (b), em $\mathrm{Wm}^{-2}$ para cada intervalo de amostragem. Evolução diária da divergência $-\nabla \cdot L^{*}$ em termos do ritmo mensal (c) e do ritomo semanal (d). $\mathrm{O}$ polígono pontilhado em (b) envolve o centro expandido da cidade de São Paulo. 


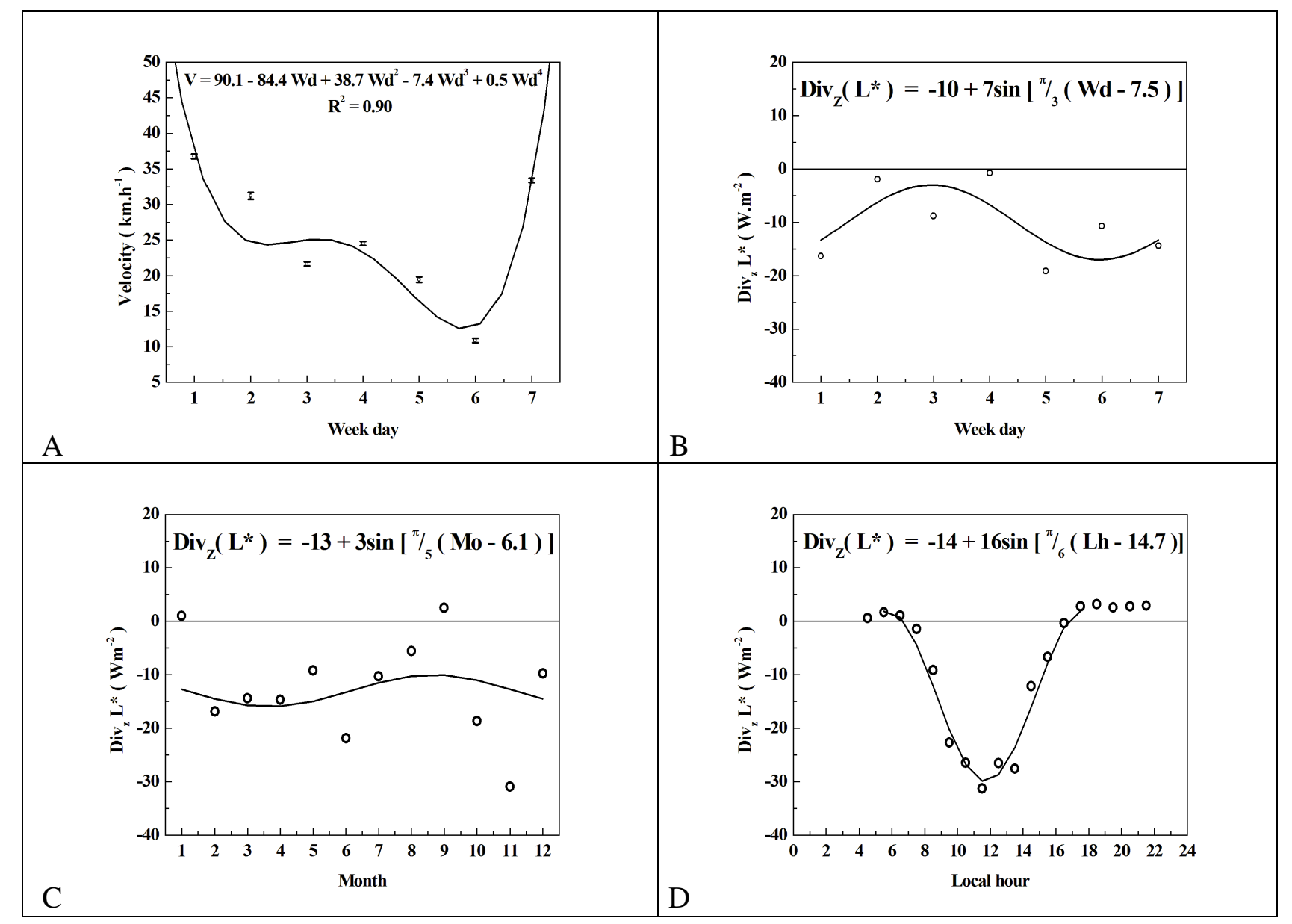

Autor: Antonio Jaschke Machado

Figura 7.8 - Evolução semanal da velocidade média desenvolvida durante os experimentos (a), com sugestão de um polinômio de quarta ordem interpolado, respectivo coeficiente quadrático de correlação e barras de erro representando o erro relativo. Evolução temporal da divergência $-\nabla \cdot L^{*}$ em termos do ritmo semanal (b), anual (c) e diário (d), com sugestão de ciclos senoidais interpolados. 


\subsubsection{RELAÇÃO COM OS POLUENTES}

A ação dos raios solares inicia a formação da névoa fotoquímica sobre a cidade (OKE, 1987, p. 319, Tab. 9.3). O dióxido de nitrogênio $\left(N O_{2}\right)$ é decomposto, originando ozônio $\left(\mathrm{O}_{3}\right)$.

“(...) Vários dos constituintes da poluição urbana são potenciais consumidores de ozônio (...), como os monóxidos de carbono (CO), nitrogênio (NO) e enxofre (SO), produzidos (...), sobretudo em processos de combustão. (...) O aumento da intensidade da atividade urbana implica em aumento das taxas de produção de monóxido de nitrogênio (...), que, consome parte do ozônio, transformando-se (novamente) em dióxido de nitrogênio.” (AZEVEDO, 2003, p. 2).

A concorrência entre as concentrações máximas para estes gases ressalta a relação entre o ritmo da atividade urbana e a concentração de ozônio na camada situada abaixo das coberturas urbanas $(U C L)$, onde se inicia a mistura dos gases atmosféricos.

Neste processo há liberação de átomos de oxigênio que se agrupam com hidrocarbonetos, formando radicais $\left(H_{C} O_{X}\right)$. Estes radicais, por sua vez, concorrem em reagir com o $\mathrm{NO}_{2}$ produzido, formando assim os nitratos peróxi-acetil (PAN).

Apesar dos óxidos de nitrogênio $\left(N O_{X}\right)$ serem naturalmente produzidos nos processos de decomposição da matéria orgânica, deve-se observar que nos ambientes densamente urbanizados não é desprezível a produção de $\mathrm{NO}_{2}$ como produto da oxidação do $\mathrm{NO}$. Sendo resultante da fixação de nitrogênio e oxigênio durante processos de combustão em veículos.

Todavia, esta combustão é incompleta devido à baixa eficiência do sistema que a ocasiona, também gerando desse modo $C O$. As emissões de $C O$ são concentradas ao longo de rodovias (volume elevado de veículos) e ruas com tráfego congestionado (densidade elevada de veículos). Este gás é estável na atmosfera, sendo removido principalmente pela atividade de microrganismos no solo. A impermeabilização dos solos na cidade deve prejudicar esta remoção.

Uma parcela considerável dos veículos na cidade utiliza óleo como combustível. Um dos produtos que é expelido durante a queima deste combustível é o dióxido de enxofre $\left(\mathrm{SO}_{2}\right)$. Este gás é o composto antropogênico de enxofre mais significativamente presente na 
atmosfera urbana. Sob condições propícias, o $\mathrm{SO}_{2}$ reage com o vapor de água, formando ácido sulfúrico. Em seguida, este ácido reage com outras substâncias para formar partículas de sulfato, que através de uma série de outros processos sedimentam-se sobre a superfície urbana.

Mas apenas cerca de $10 \%$ do material particulado $(P M)$ provém de fontes antrópicas, como a combustão, ou como a atividade associada às edificações de engenharia civil. De modo geral, excetuando-se os casos locais de extrema intensificação destas atividades, cerca de $90 \%$ do $P M$ é derivado de fontes naturais, podendo surgir tanto no estado sólido como também no líquido.

\subsubsection{Parametrização das concentrações}

A distribuição de concentração de poluentes (Figs. 7.9 a 7.22) apresenta um padrão com valores mínimos (exceção feita a PM) em torno de $30 \mathrm{kmh}^{-1} \mathrm{e}-30 \mathrm{Wm}^{-2}$ (para detalhes sobre os dados de poluentes ver item 5; MACHADO e AZEVEDO, 2007b).

Os valores máximos estão associados tanto a velocidades baixas como a velocidades elevadas. E em termos de $-\nabla_{h} \cdot L^{*}$, as concentrações máximas estão associadas a valores quase nulos desta divergência, sob um viés ligeiramente positivo. Como também a valores negativos elevados, entre $-40 \mathrm{Wm}^{-2} \mathrm{e}-50 \mathrm{Wm}^{-2}$ (exceção feita a $\mathrm{PM}$ ). A melhor correlação foi encontrada entre $-\nabla_{h} \cdot L *$ e $\mathrm{SO}_{2}$, superior a 0,94 .

Os núcleos intensos e negativos de $-\nabla_{h} \cdot L^{*}$ concordam com a ocorrência de valores mínimos dos poluentes gasosos (Figs. 7.11 a 7.22). Todavia, para o caso das partículas sólidas (Fig. 7.9 e 7.10) o oposto se verifica. Uma grande área com valores elevados da concentração de $P M$ é verificada justamente no setor onde predominam as áreas de mata a nordeste da área metropolitana, e, além disso, é também verificada uma pequena área com valores mais elevados no centro do domínio, na área com maior densidade de parques urbanos. Isto indica que os poluentes sólidos têm realmente origem predominantemente natural.

Os indícios apresentados apontam para uma relação exponencial-linear entre a concentração de $P M$ e $V_{M}$. Enquanto para os demais poluentes o melhor ajuste ocorre para 
relações polinomias de segunda à quarta ordem. No caso de $-\nabla_{h} \cdot L^{*}$ as relações são sempre polinomiais. Estas relações podem ser expressas de modo sintético (Figs. 7.10, 7.12, 7.14, 7.16, 7.18, 7.20, 7.22, d, acima), através de um somatório de termos cujos coeficientes $\left(a_{N}\right)$ são os parâmetros procurados.

\subsubsection{Mistura termodinâmica}

Deve-se considerar que os valores de $V_{M}$ são representativos da própria velocidade média na metrópole. O deslocamento do laboratório móvel é afetado pelo tráfego de veículos ao redor, enquanto os valores de $-\nabla_{h} \cdot L^{*}$ são representativos de maior (valores negativos) ou menor (valores positivos) exposição do chão ao aquecimento por incidência da radiação solar.

Para os poluentes sólidos $(P M)$, a taxa de concentração apresenta valores máximos sob duas circunstâncias distintas. A primeira, com baixos valores de $V_{M}$, deve-se à elevada densidade de veículos. Neste caso, a turbulência é menos intensa, porém age de maneira constante e uniforme por um período relativamente longo. Os "engarrafamentos" na cidade podem levar horas para dissiparem-se, re-suspendendo sistematicamente o material. Já a segunda, com elevados valores de $V_{M}$, é devida ao volume elevado de veículos. Nas vias expressas a densidade de veículos é freqüentemente menor, porém o volume é em geral maior. A possibilidade de deslocamentos mais rápidos torna a turbulência mecânica mais intensa, e apesar de ser mais irregular é capaz de agir mantendo o material suspenso por um intervalo maior.

Há indícios de um valor negativo "ideal" de $-\nabla_{h} \cdot L^{*}$ capaz de manter o material sólido em suspensão, justamente na camada atmosférica em que são medidos. Sob valores muito baixos de $-\nabla_{h} \cdot L^{*}$ as concentrações são menores devido à maior estabilidade da camada, que fica sujeita ou aos fracos deslocamentos verticais adiabáticos, ou à subsidência associada à inversão térmica. Mas há também uma tendência de redução na concentração para valores negativos elevados. Neste caso, o lapse rate da camada é suficiente para gerar deslocamentos verticais convectivos mais intensos, distribuindo o material suspenso em um volume maior. 
Para os poluentes gasosos a interpretação requer um ajuste, pois a ação gravitacional e as forças de tração perdem relevância em comparação ao empuxo associado à convecção. Os máximos observados em relação a $-\nabla_{h} \cdot L^{*}$, para valores em torno de zero, são a única evidência de elevação na concentração de poluentes por um fator puramente físico. Ou seja, um lapse rate tênue é suficiente para gerar pequenos turbilhões capazes de manter os poluentes misturados na camada em que são observados. Conforme $-\nabla_{h} \cdot L^{*}$ torna-se mais intenso, as concentrações caem abruptamente devido aos grandes turbilhões (termas), que se desenvolvem conforme a convecção evolui, suspendendo os gases para camadas mais elevadas.

Todavia, são evidentes altas concentrações nas situações com baixas magnitudes de $V_{M}$, e de modo menos evidente em relação aos elevados valores de $V_{M}$ e $-\nabla_{h} \cdot L^{*}$. Nestes casos, o fator químico passa a ser preponderante, pois são situações geradoras de poluentes gasosos. Baixos valores de $V_{M}$ e elevados valores negativos de $-\nabla_{h} \cdot L^{*}$ indicam um ambiente congestionado de veículos e com grande disponibilidade de radiação solar. O indicativo de $-\nabla_{h} \cdot L^{*}$ como elemento representativo de uma fonte química é respaldado pela distribuição de $\mathrm{SO}_{2}$. Mas não há evidências para assegurar os elevados valores de $V_{M}$ como indicadores de uma fonte química. Nos casos investigados, não fica claro se há realmente a ocorrência deste máximo, ou se os valores acomodam-se em torno de um patamar característico da camada. 


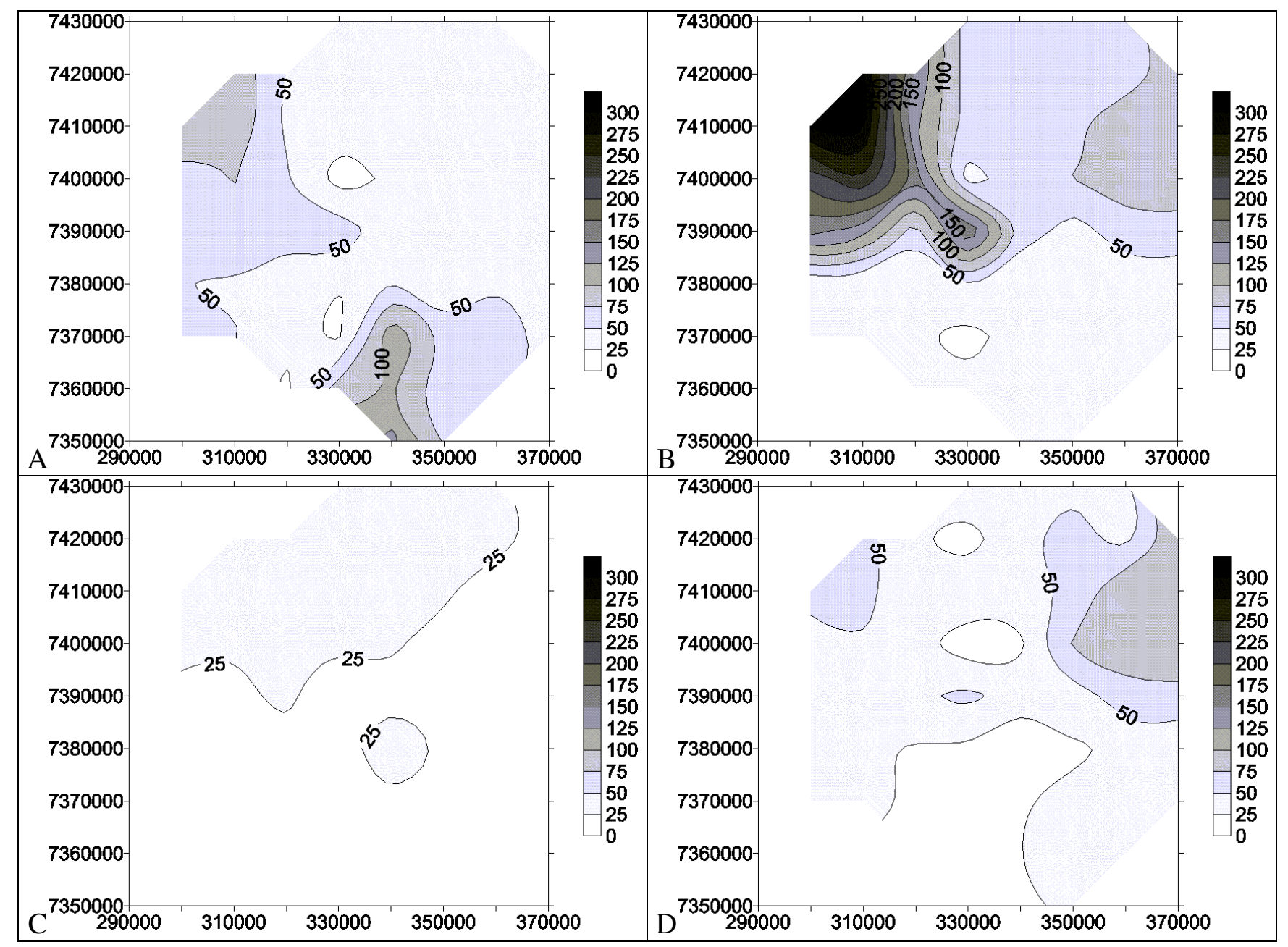

Autor: Antonio Jaschke Machado

Figura 7.9 - Evolução da distribuição espacial da concentração de material particulado $\left(\mu \operatorname{gm}^{-3}\right)$ na região metropolitana de São Paulo nos anos de 2002 (a), 2003 (b), 2004 (d) e 2005 (c), sentido horário. 


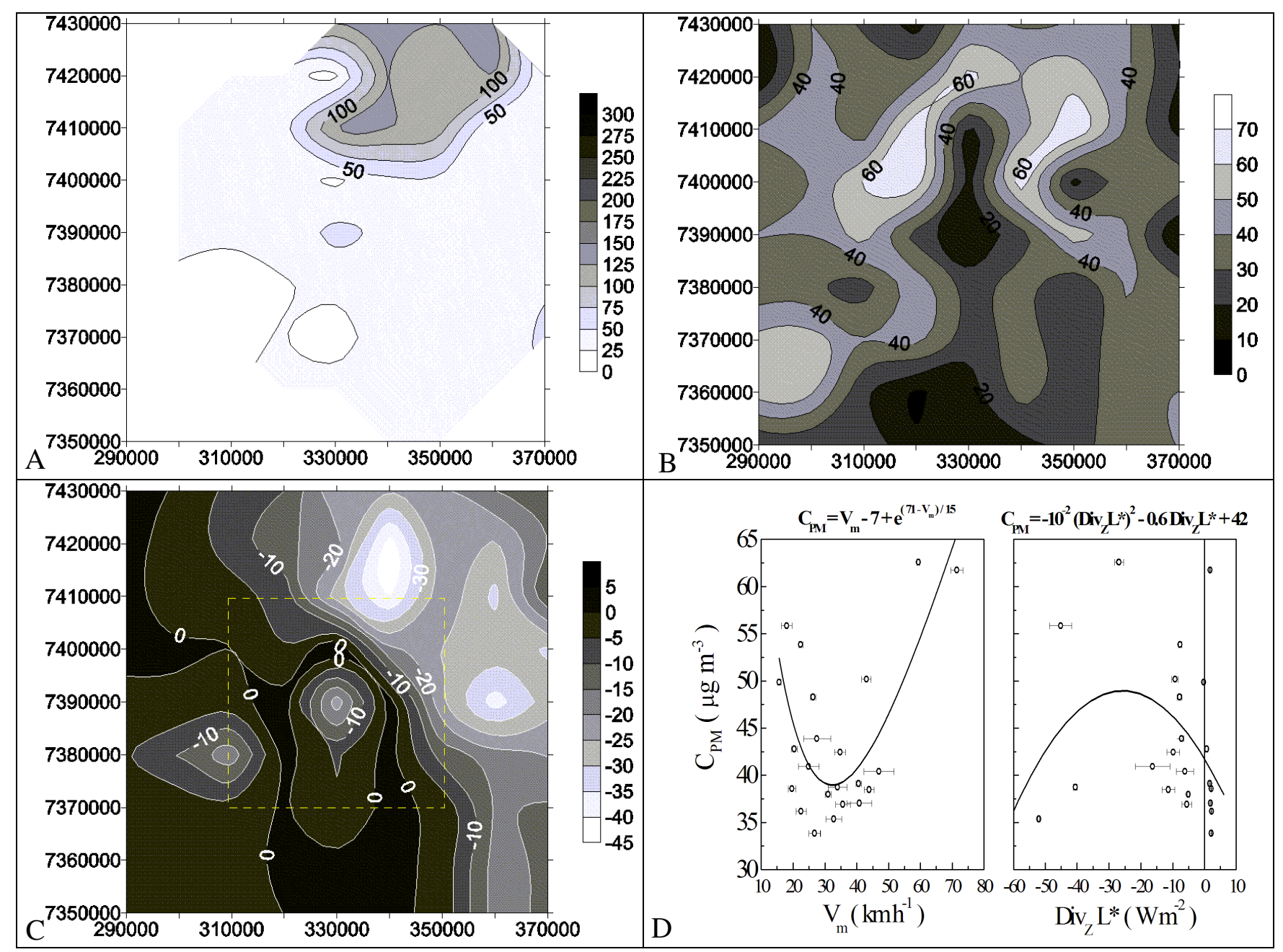

Autor: Antonio Jaschke Machado

Figura 7.10 - Distribuição média da concentração de material particulado $\left(\mu \mathrm{gm}^{-3}\right)$ na região metropolitana de São Paulo, em termos de sua relação espacial para o período entre 2002 e 2005 (a) e em termos de sua relação com a velocidade média veicular estimada em $\mathrm{kmh}^{-1}(\mathrm{~d}$ - esquerda) e com a divergência $-\nabla \cdot L *$ estimada em $\mathrm{Wm}^{-2}(\mathrm{~d}$ - direita). As barras de erro representam o desvio padrão. São sugeridas expressões polinomias e exponenciais para as relações em (d). Distribuição espacial da velocidade média veicular (b) e da divergência $-\nabla \cdot L *(\mathrm{c})$, estimadas para o ano de 2007. 


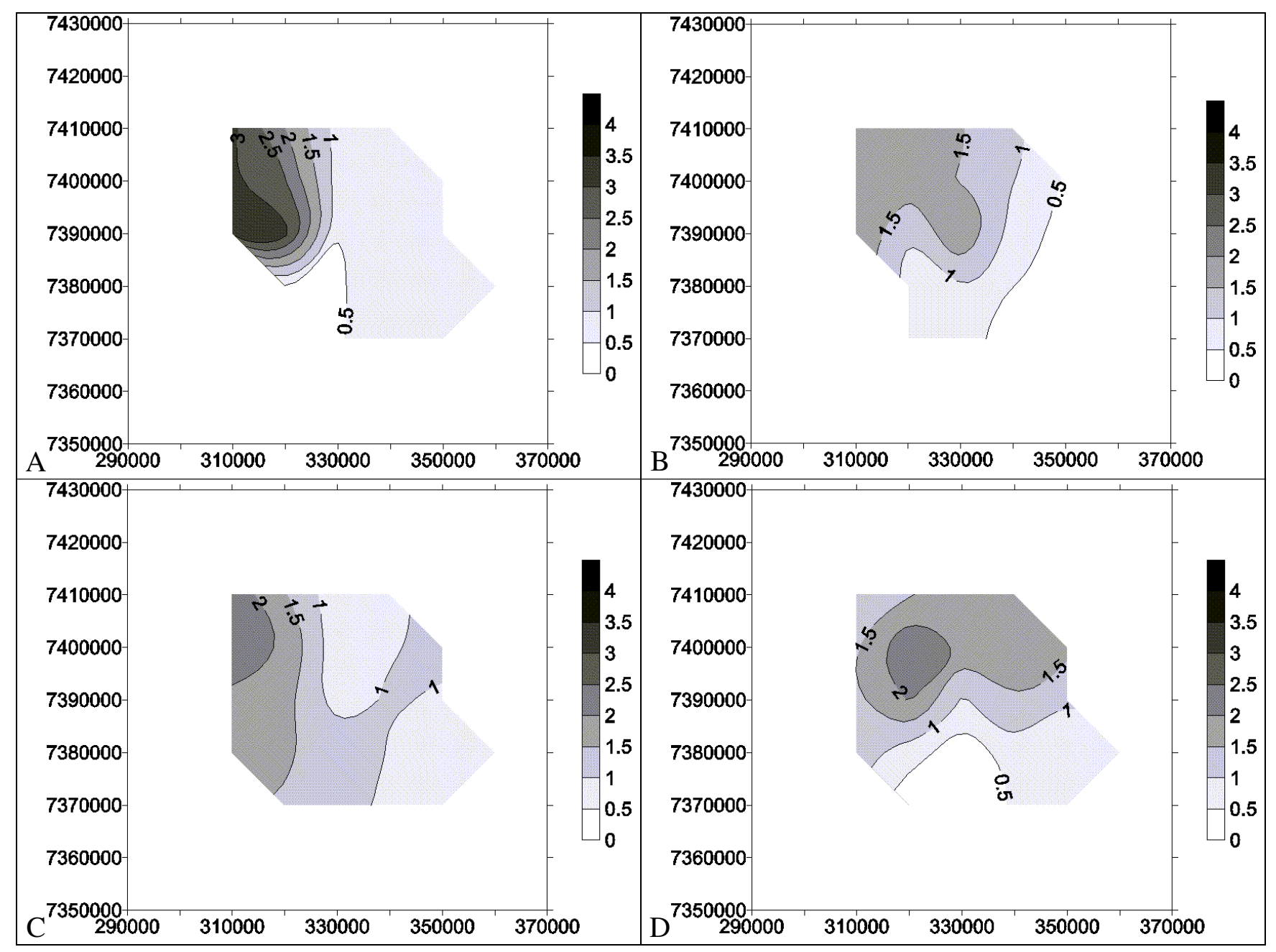

Autor: Antonio Jaschke Machado

Figura 7.11 - Evolução da distribuição espacial da concentração de monóxido de carbono (ppm) na região metropolitana de São Paulo nos anos de 2002 (a), 2003 (b), 2004 (d) e 2005 (c), sentido horário. 


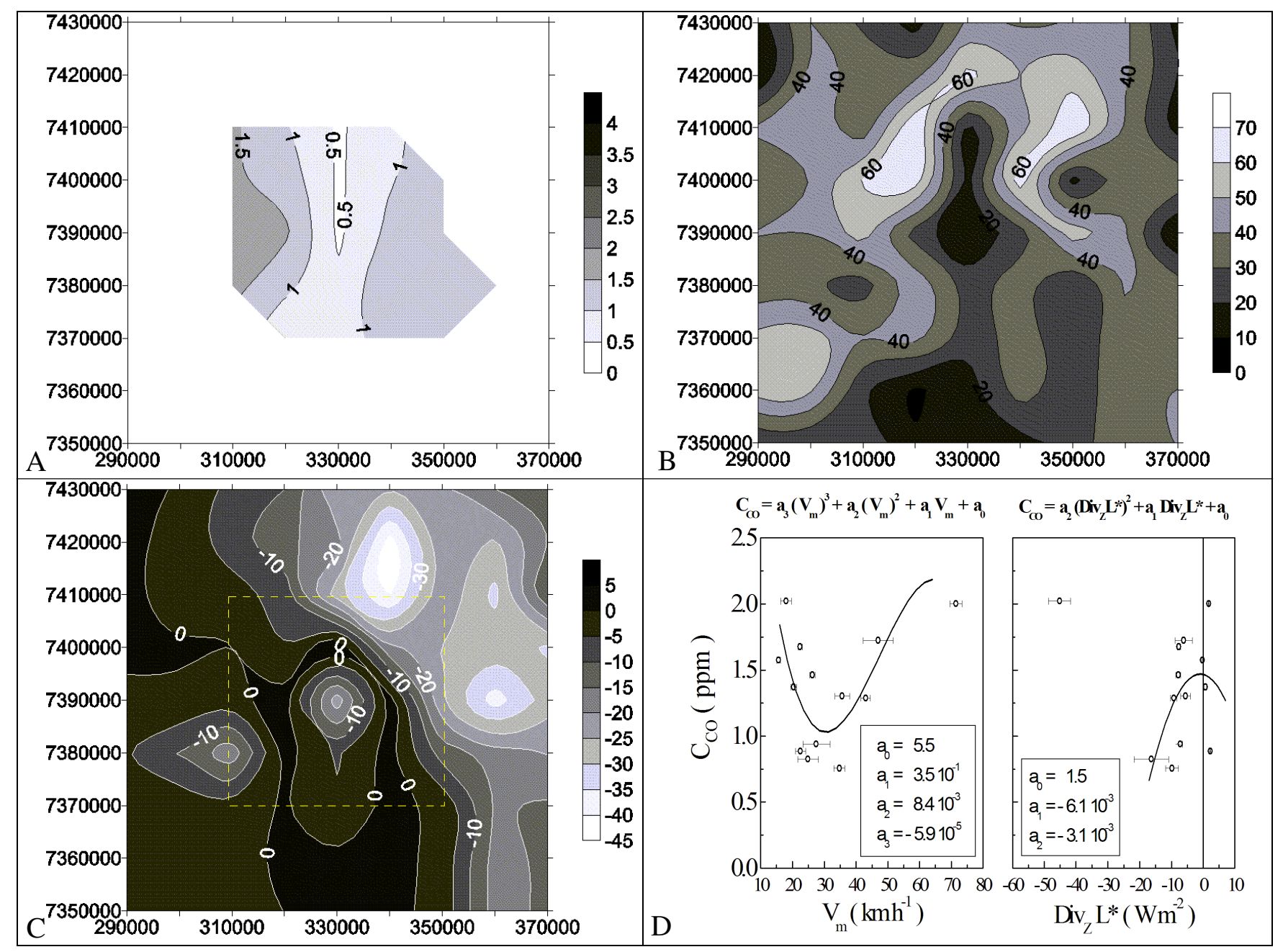

Autor: Antonio Jaschke Machado

Figura 7.12 - Distribuição média da concentração de monóxido de carbono (ppm) na região metropolitana de São Paulo, em termos de sua relação espacial para o período entre 2002 e 2005 (a) e em termos de sua relação

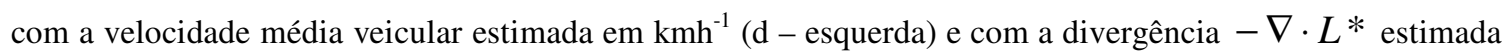
em $\mathrm{Wm}^{-2}(\mathrm{~d}$ - direita). As barras de erro representam o desvio padrão. São sugeridas expressões polinomias de segunda e terceira ordem para as relações em (d). Distribuição espacial da velocidade média veicular (b) e da divergência $-\nabla \cdot L^{*}$ (c), estimadas para o ano de 2007. 


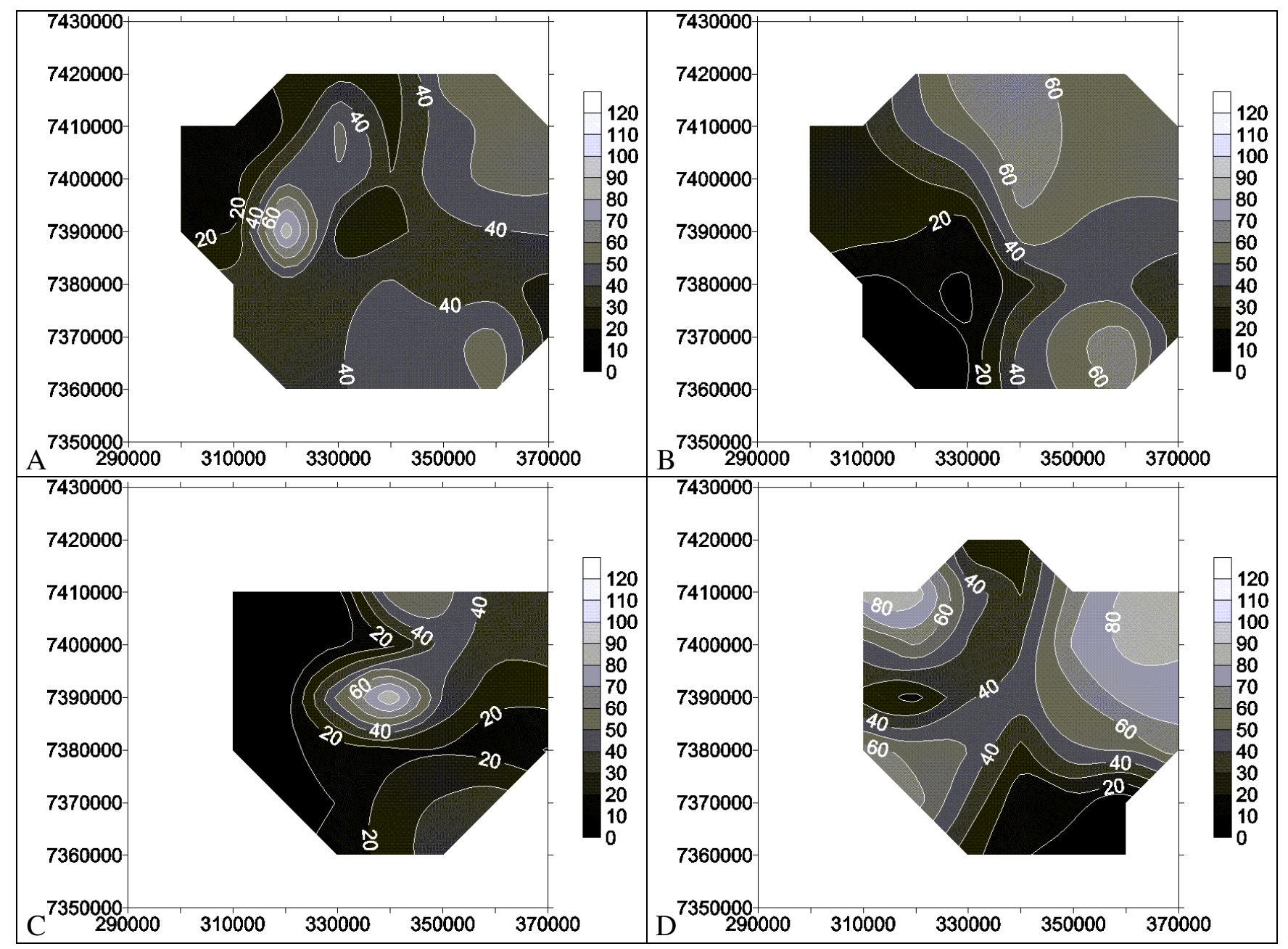

Autor: Antonio Jaschke Machado

Figura 7.13 - Evolução da distribuição espacial da concentração de ozônio $\left(\mu \mathrm{gm}^{-3}\right)$ na região metropolitana de São Paulo nos anos de 2002 (a), 2003 (b), 2004 (d) e 2005 (c), sentido horário. 


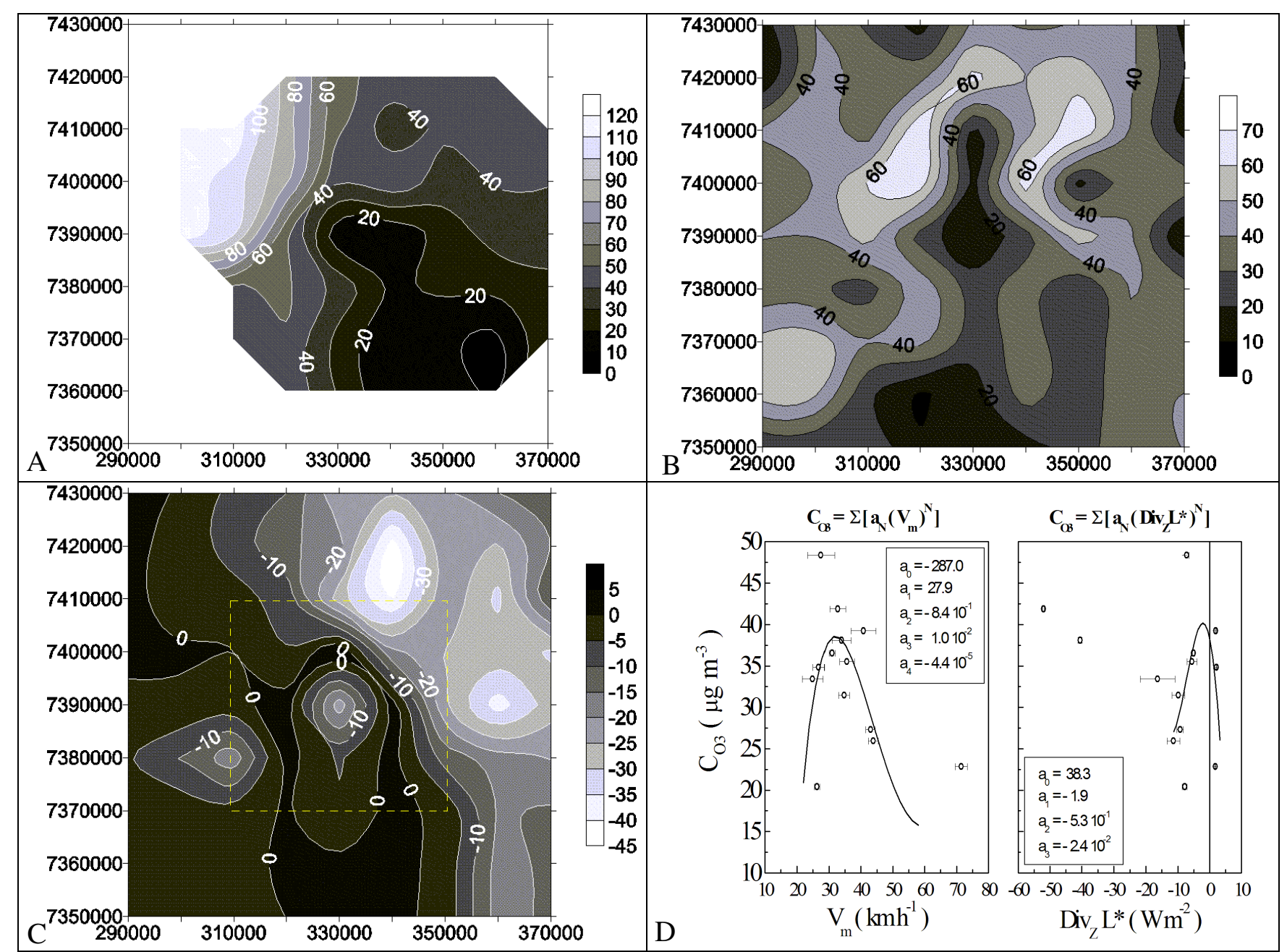

Autor: Antonio Jaschke Machado

Figura 7.14 - Distribuição média da concentração de ozônio $\left(\mu \mathrm{gm}^{-3}\right)$ na região metropolitana de São Paulo, em termos de sua relação espacial para o período entre 2002 e 2005 (a) e em termos de sua relação com a

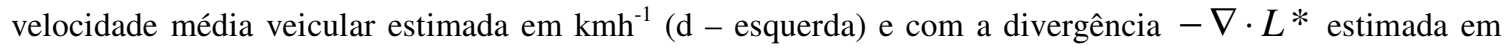
$\mathrm{Wm}^{-2}(\mathrm{~d}$ - direita). As barras de erro representam o desvio padrão. São sugeridas expressões polinomias de terceira e quarta ordens para as relações em (d). Distribuição espacial da velocidade média veicular (b) e da divergência $-\nabla \cdot L^{*}(\mathrm{c})$, estimadas para o ano de 2007. 


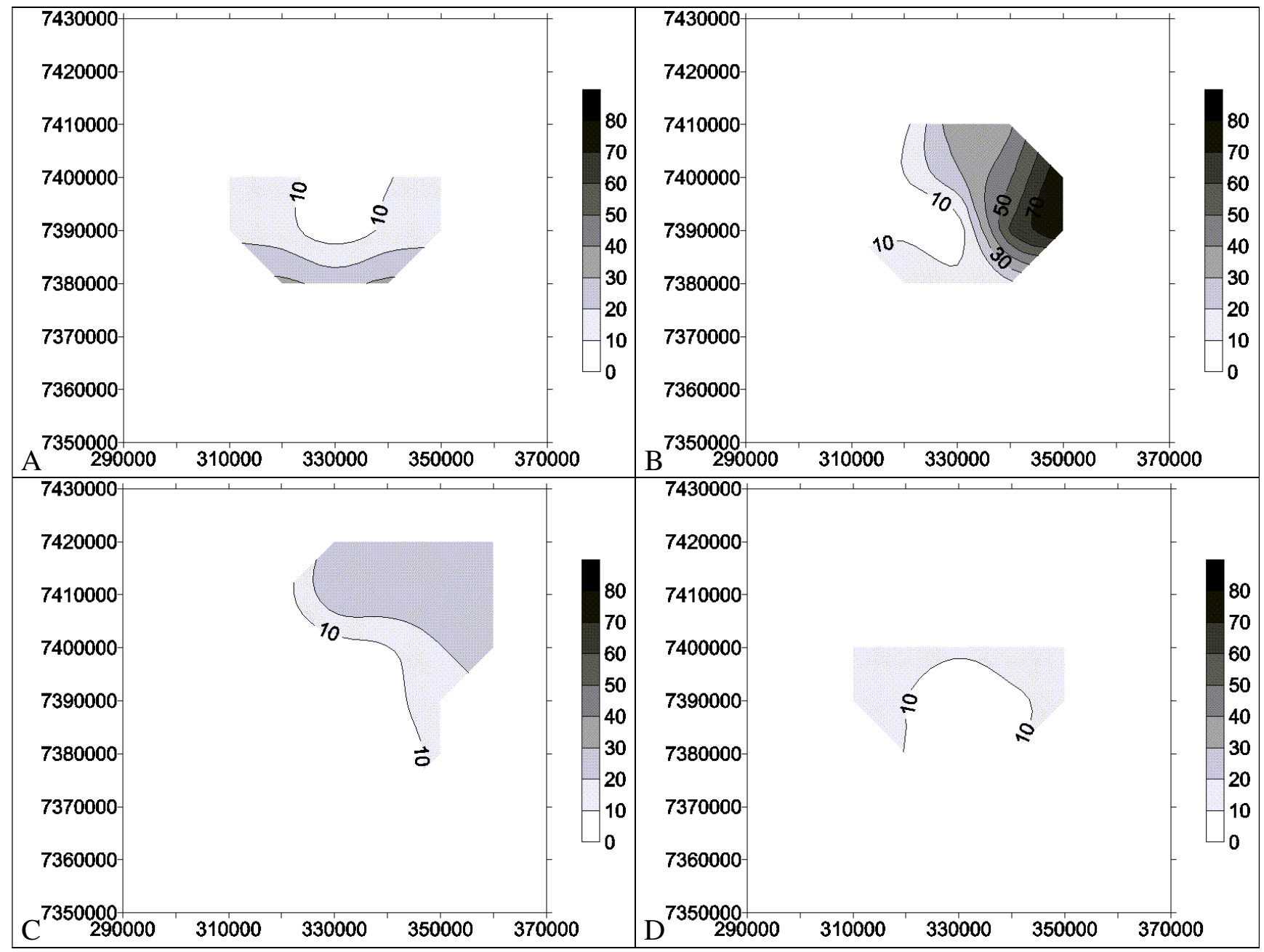

Autor: Antonio Jaschke Machado

Figura 7.15 - Evolução da distribuição espacial da concentração de dióxido de enxofre $\left(\mu \operatorname{gm}^{-3}\right)$ na região metropolitana de São Paulo nos anos de 2002 (a), 2003 (b), 2004 (d) e 2005 (c), sentido horário. 


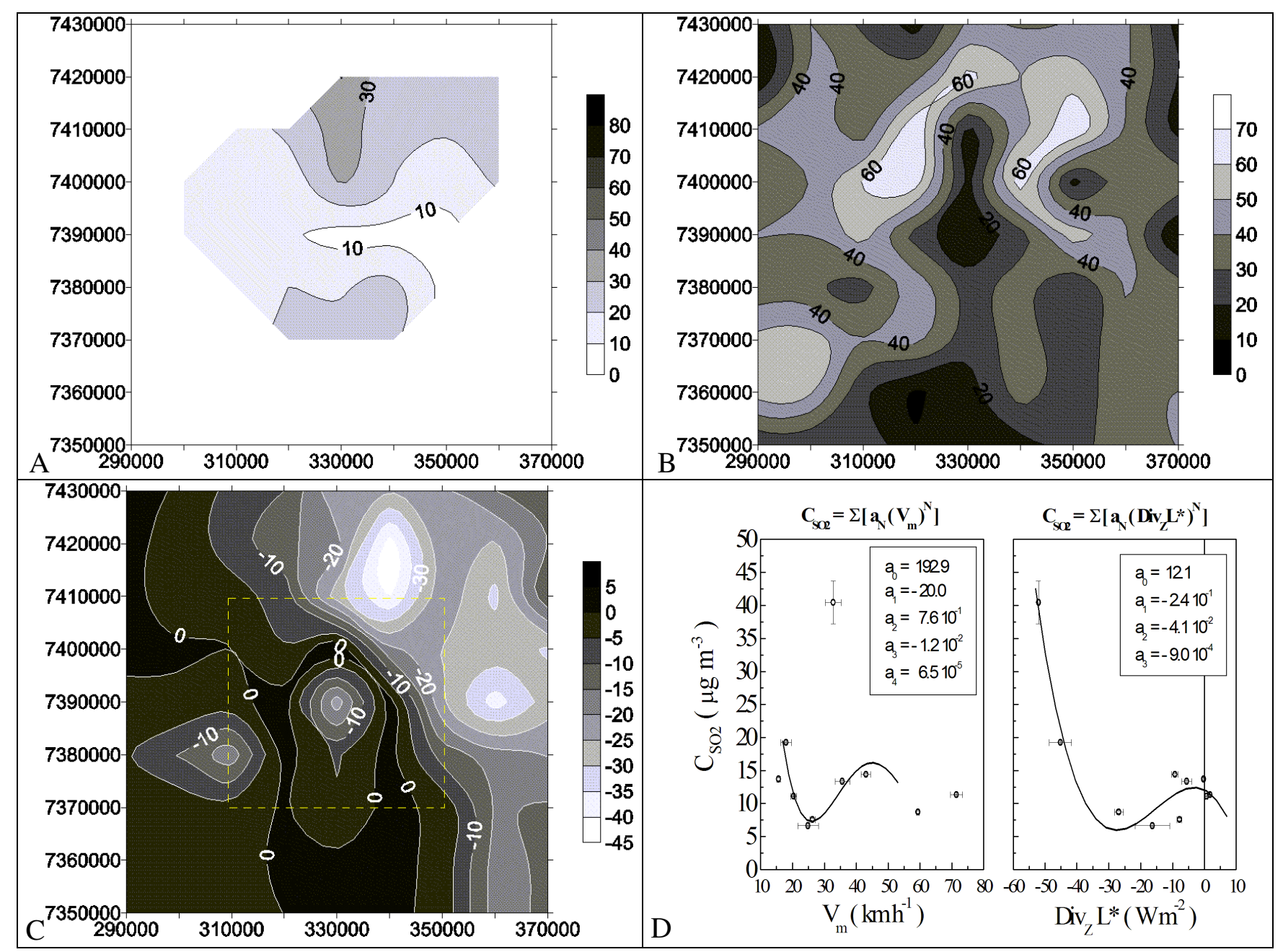

Autor: Antonio Jaschke Machado

Figura 7.16 - Distribuição média da concentração de dióxido de enxofre $\left(\mu \mathrm{gm}^{-3}\right)$ na região metropolitana de São Paulo, em termos de sua relação espacial para o período entre 2002 e 2005 (a) e em termos de sua relação com a velocidade média veicular estimada em $\mathrm{kmh}^{-1}(\mathrm{~d}$ - esquerda) e com a divergência $-\nabla \cdot L *$ estimada em $\mathrm{Wm}^{-2}(\mathrm{~d}$ - direita). As barras de erro representam o desvio padrão. São sugeridas expressões polinomias de terceira e quarta ordens para as relações em (d). Distribuição espacial da velocidade média veicular (b) e da divergência $-\nabla \cdot L^{*}(\mathrm{c})$, estimadas para o ano de 2007. 


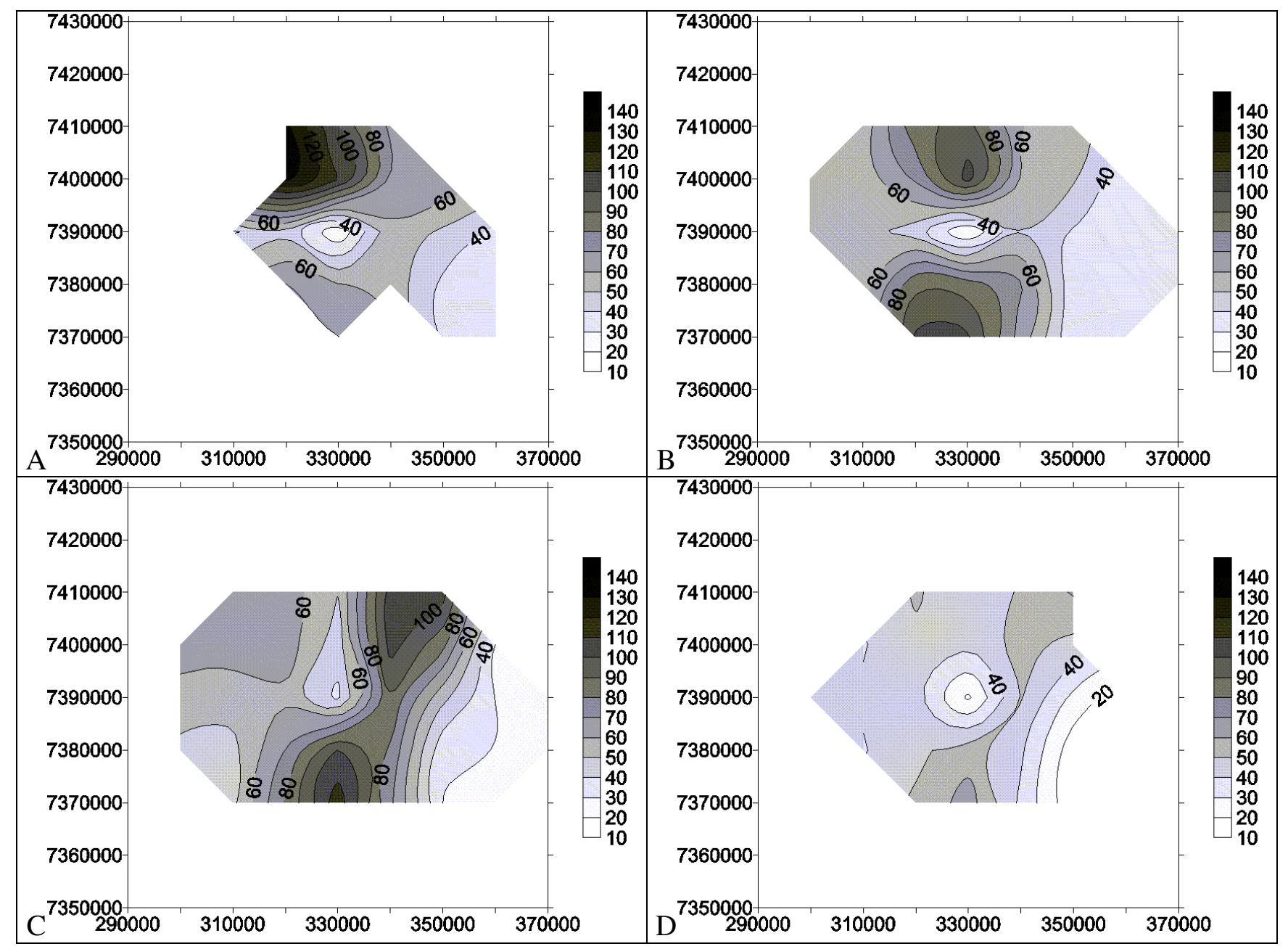

Autor: Antonio Jaschke Machado

Figura 7.17 - Evolução da distribuição espacial da concentração de dióxido de nitrogênio $\left(\mu \mathrm{gm}^{-3}\right)$ na região metropolitana de São Paulo nos anos de 2002 (a), 2003 (b), 2004 (d) e 2005 (c), sentido horário. 


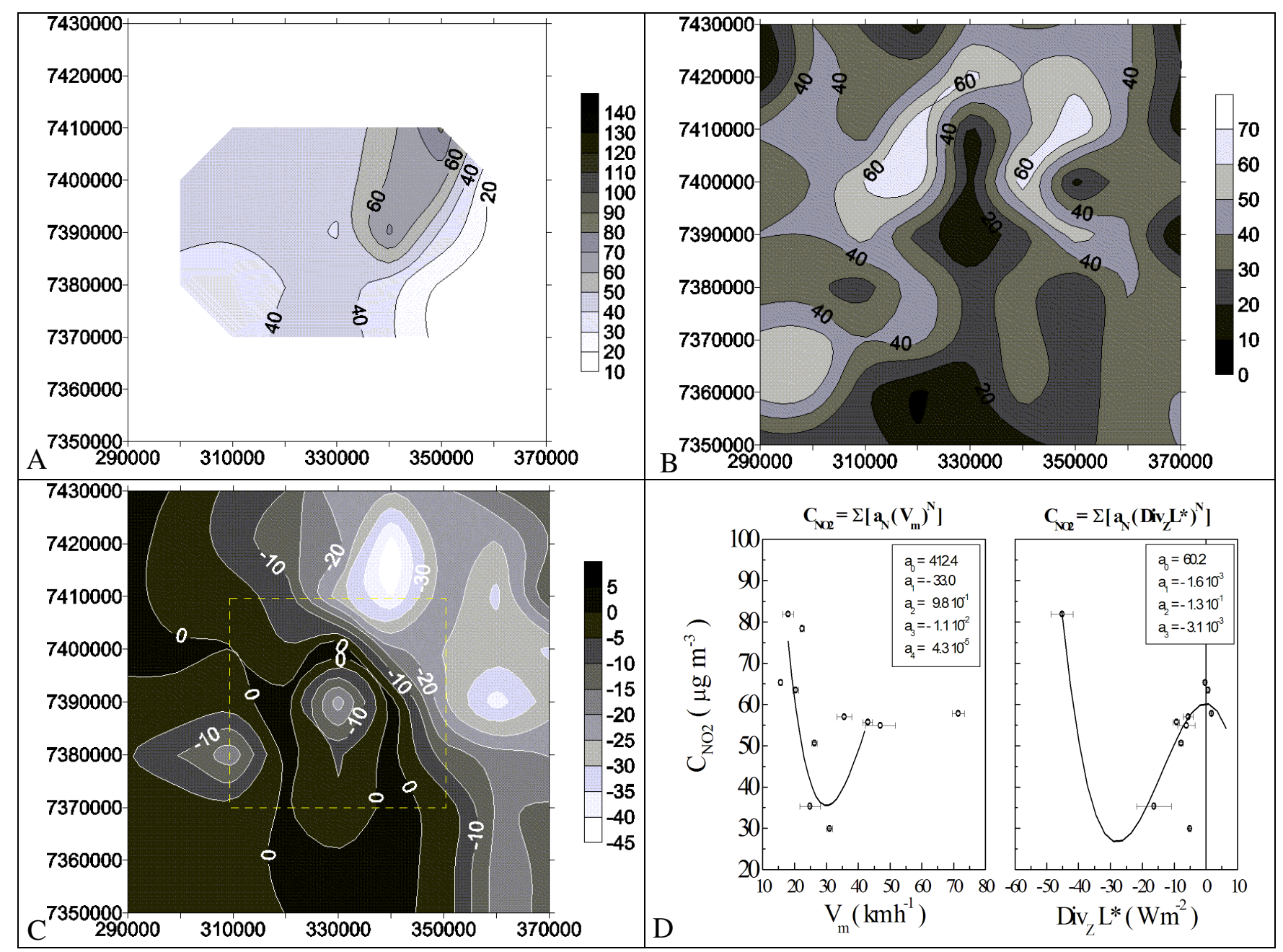

Autor: Antonio Jaschke Machado

Figura 7.18 - Distribuição média da concentração de dióxido de nitrogênio $\left(\mu \operatorname{gm}^{-3}\right)$ na região metropolitana de São Paulo, em termos de sua relação espacial para o período entre 2002 e 2005 (a) e em termos de sua relação com a velocidade média veicular estimada em $\mathrm{kmh}^{-1}(\mathrm{~d}$ - esquerda) e com a divergência $-\nabla \cdot L *$ estimada em $\mathrm{Wm}^{-2}$ (d - direita). As barras de erro representam o desvio padrão. São sugeridas expressões polinomias de terceira e quarta ordens para as relações em (d). Distribuição espacial da velocidade média veicular (b) e da divergência $-\nabla \cdot L^{*}$ (c), estimadas para o ano de 2007. 


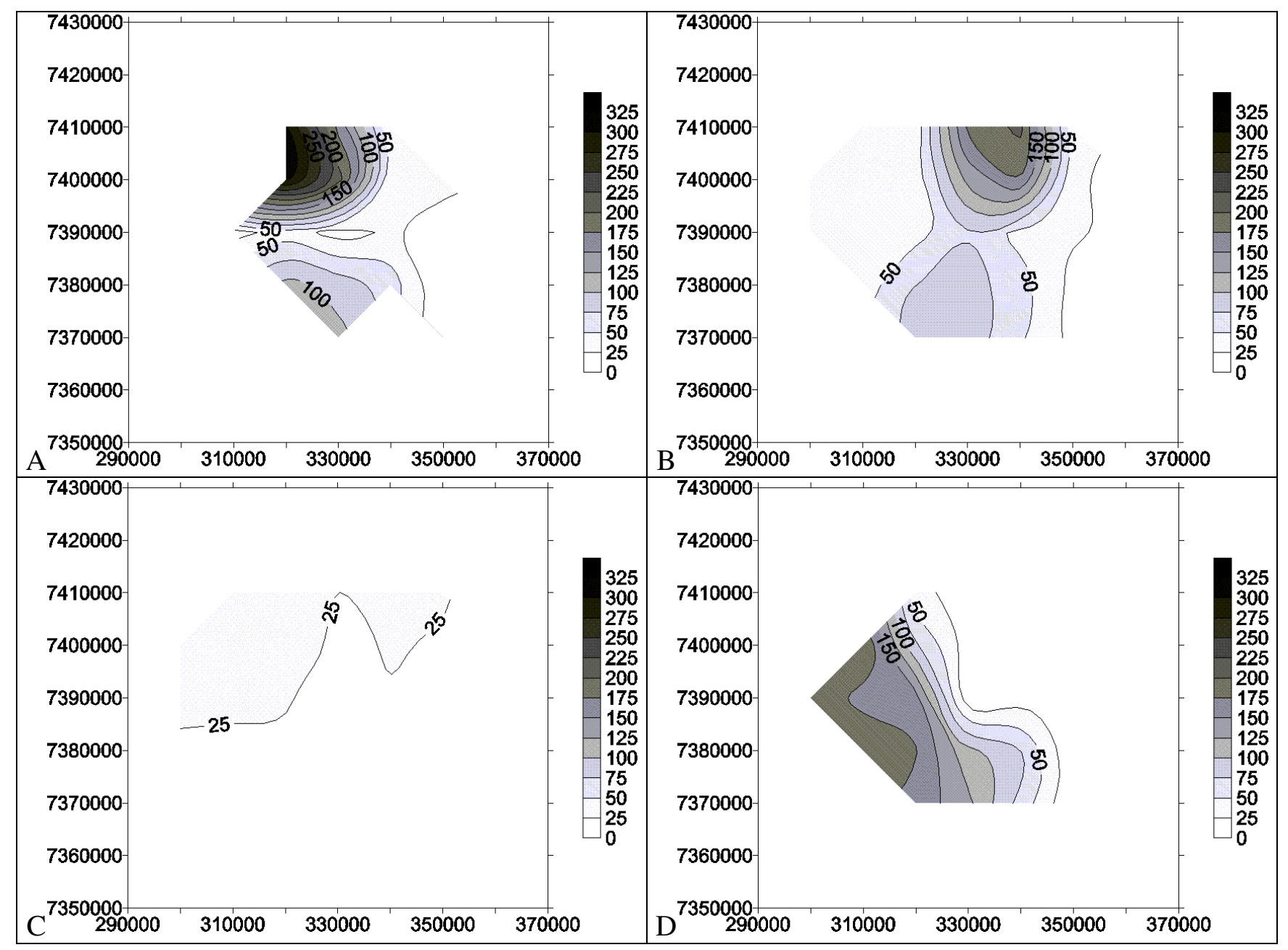

Autor: Antonio Jaschke Machado

Figura 7.19 - Evolução da distribuição espacial da concentração de monóxido de nitrogênio $\left(\mu \mathrm{gm}^{-3}\right)$ na região metropolitana de São Paulo nos anos de 2002 (a), 2003 (b), 2004 (d) e 2005 (c), sentido horário. 


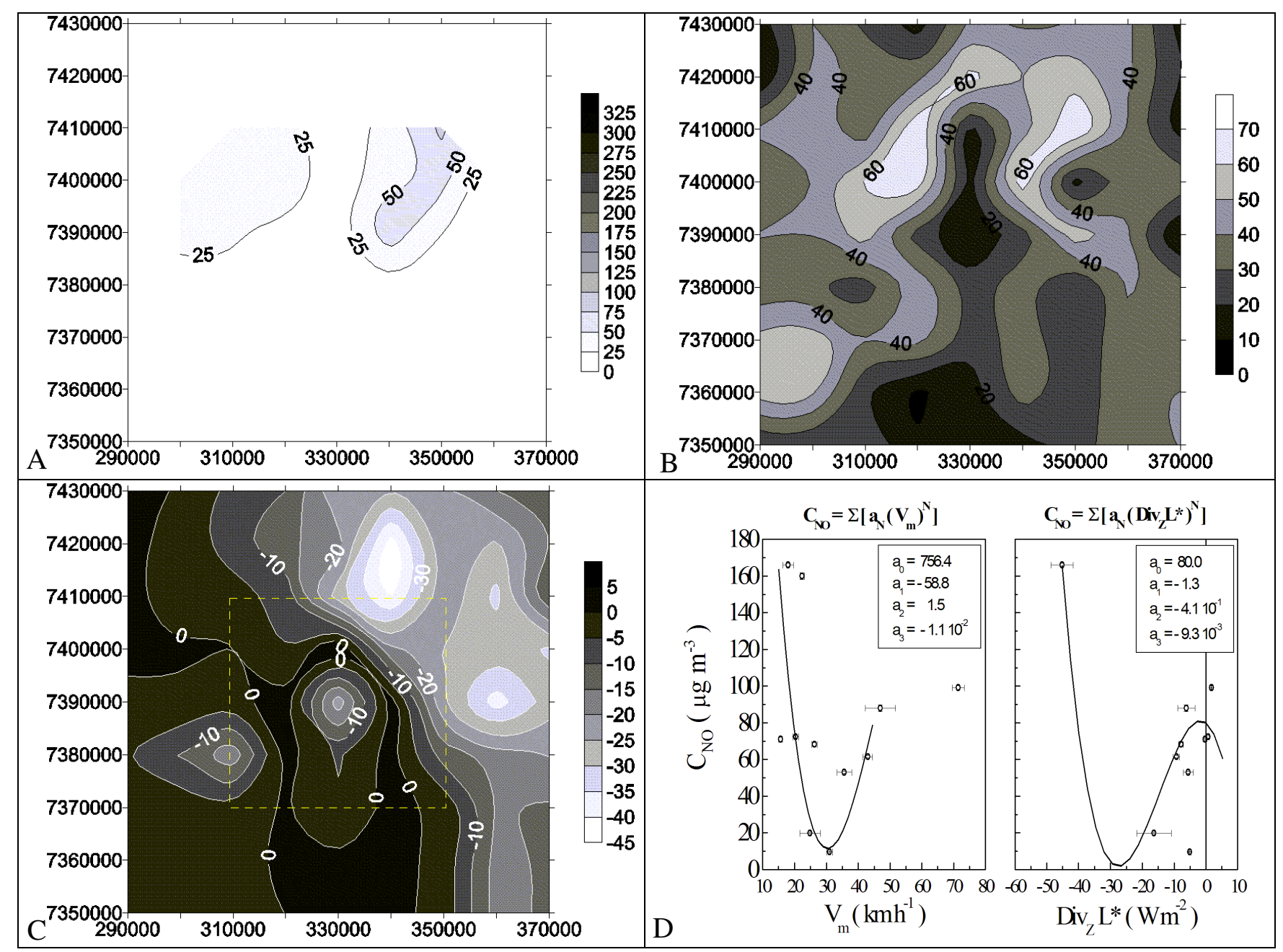

Autor: Antonio Jaschke Machado

Figura 7.20 - Distribuição média da concentração de monóxido de nitrogênio ( $\mu g^{-3}{ }^{-3}$ na região metropolitana de São Paulo, em termos de sua relação espacial para o período entre 2002 e 2005 (a) e em termos de sua relação com a velocidade média veicular estimada em $\mathrm{kmh}^{-1}$ ( $\mathrm{d}$ - esquerda) e com a divergência $-\nabla \cdot L^{*}$ estimada em $\mathrm{Wm}^{-2}(\mathrm{~d}-$ direita). As barras de erro representam o desvio padrão. São sugeridas expressões polinomias de terceira ordem para as relações em (d). Distribuição espacial da velocidade média veicular (b) e da divergência $-\nabla \cdot L^{*}$ (c), estimadas para o ano de 2007. 


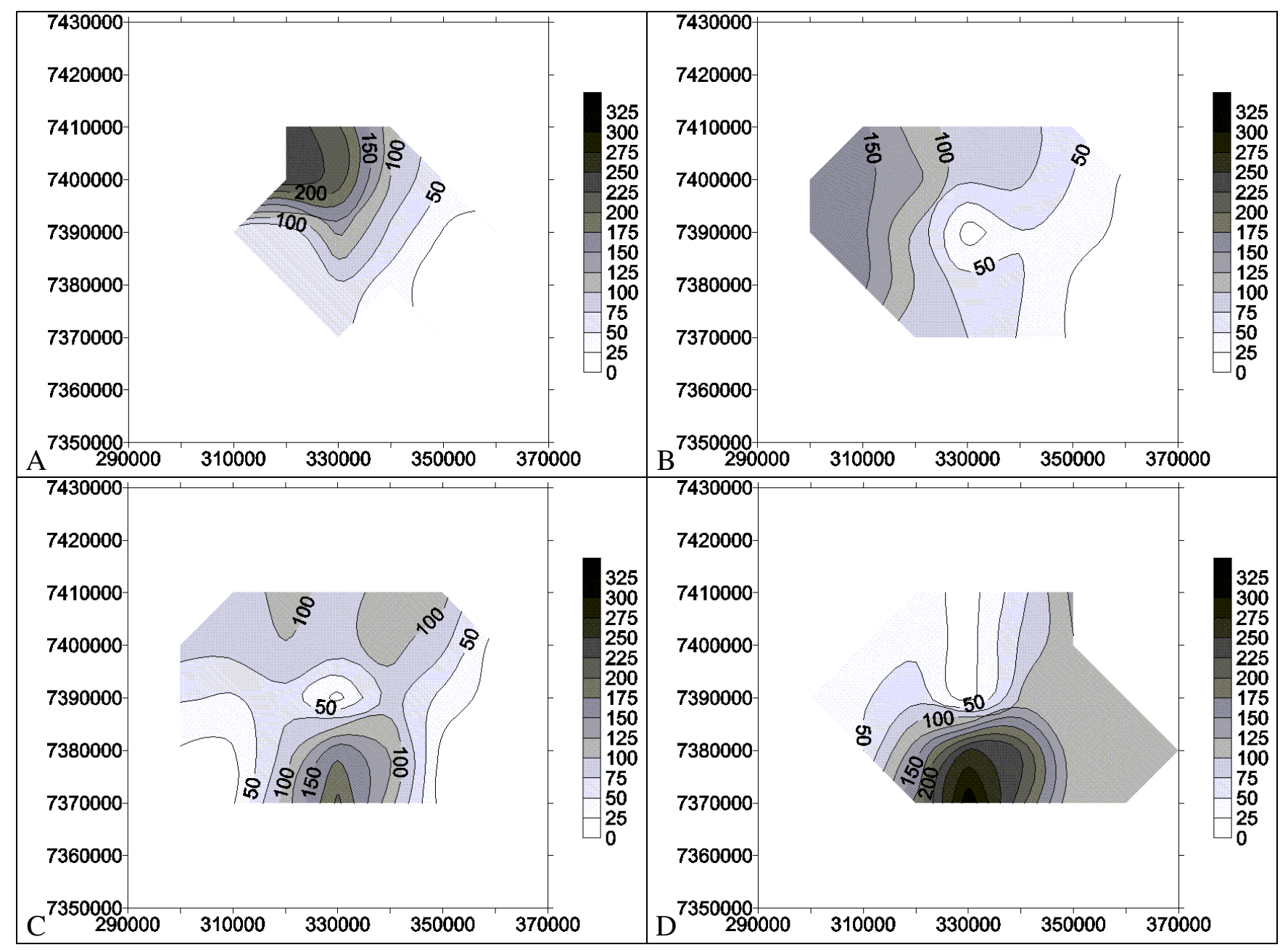

Autor: Antonio Jaschke Machado

Figura 7.21 - Evolução da distribuição espacial da concentração dos óxidos de nitrogênio (ppb), excetuandose o NO e o $\mathrm{NO}_{2}$, na região metropolitana de São Paulo nos anos de 2002 (a), 2003 (b), 2004 (d) e 2005 (c), sentido horário. 


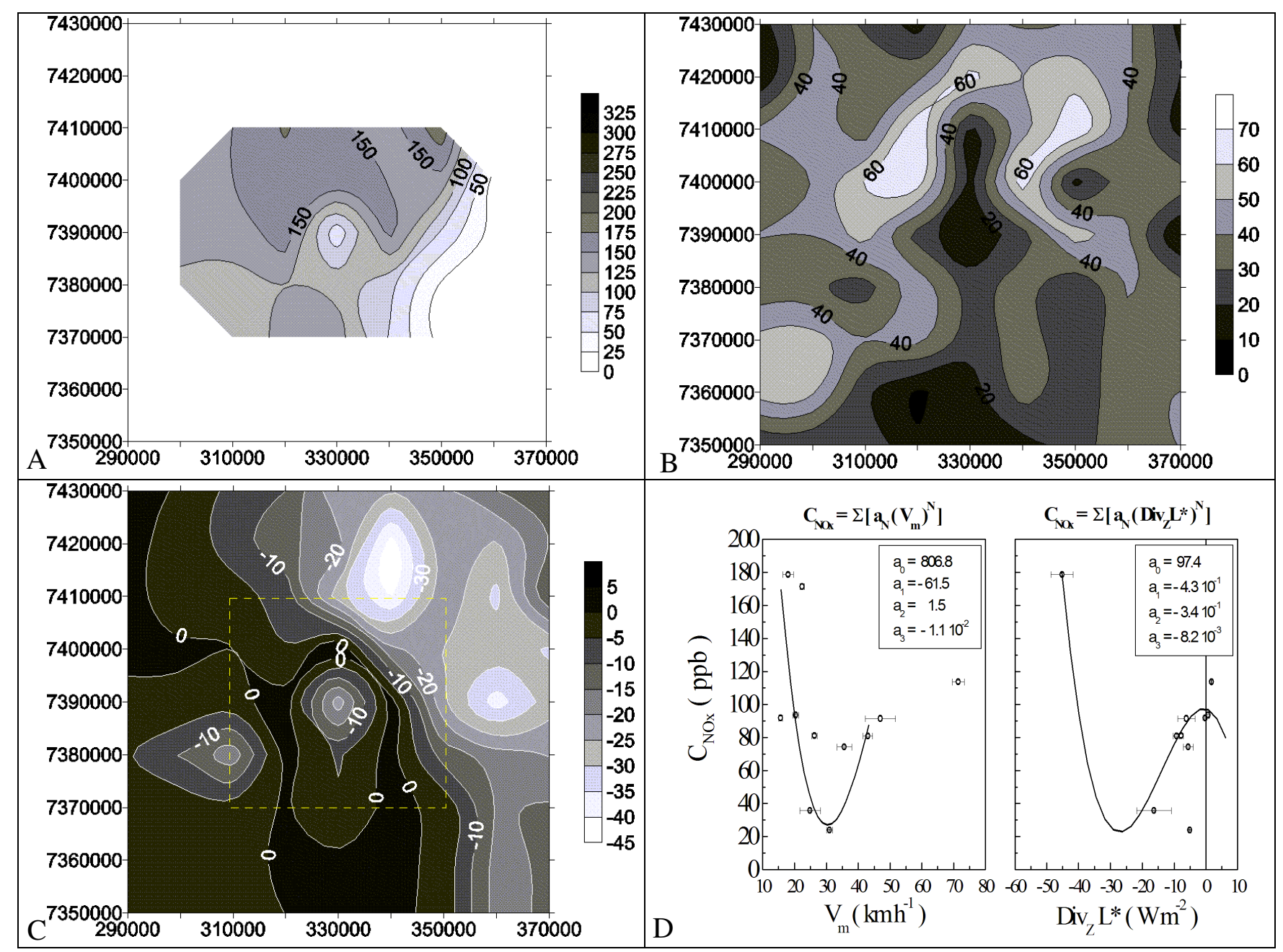

Autor: Antonio Jaschke Machado

Figura 7.22 - Distribuição média da concentração de óxidos de nitrogênio (ppb), exceto o $\mathrm{NO}$ e o $\mathrm{NO}_{2}$, na região metropolitana de São Paulo, em termos de sua relação espacial para o período entre 2002 e 2005 (a) e em termos de sua relação com a velocidade média veicular estimada em $\mathrm{kmh}^{-1}$ (d - esquerda) e com a divergência $-\nabla \cdot L^{*}$ estimada em $\mathrm{Wm}^{-2}(\mathrm{~d}-$ direita $)$. As barras de erro representam o desvio padrão. São sugeridas expressões polinomias de terceira ordem para as relações em (d). Distribuição espacial da velocidade média veicular (b) e da divergência $-\nabla \cdot L^{*}$ (c), estimadas para o ano de 2007. 


\subsubsection{BALANÇO ENERGÉTICO}

\subsubsection{Parametrização do fluxo $L_{a} \downarrow$}

Sob condições de céu claro, as estimativas urbanas de $L \downarrow$ podem ser diferentes das medições por causa da variabilidade dos aerossóis atmosféricos (OFFERLE et alii, 2003). Ao comparar seis fórmulas de emissividade, para condições de céu claro, Prata (1996) encontrou rmse (root mean square error) variando de 10 a $22 \mathrm{Wm}^{-2}$, para uma grande variedade de locais.

Assim, devido ao fluxo $L \downarrow$ ser menos observado que $K \downarrow$, deve ser apresentada uma estimativa de $L \downarrow$ e analisada sua validação em relação aos fluxos observados no trajeto e à ocupação do solo. Utiliza-se, então, um modelo atmosférico de uma única camada (OFFERLE et alii, 2003), conforme a Equação 1.3, tal que:

$\mathrm{L}_{\mathrm{a}} \downarrow=\varepsilon_{\mathrm{a}} \sigma \mathrm{T}_{\text {ceu }}^{4}$

Onde, $\mathrm{T}_{\text {ceu }}$ é a temperatura atmosférica volumétrica (em graus Kelvin) aproximada pela temperatura próxima à superfície $\left(\mathrm{T}_{\mathrm{a}}\right)$ e $\varepsilon_{\mathrm{a}}$ é a emissividade atmosférica ampla estimada:

$\varepsilon_{\mathrm{a}}=\varepsilon_{\text {claro }}+\varepsilon_{\text {nuvem }}$

Os esquemas de emissividade para o céu claro $\left(\varepsilon_{\text {claro }}\right)$ ao nível da superfície têm sido revistos com detalhes em várias localidades (PRATA, 1996; CRAWFORD e DUCHON, 1999; NIEMELÄ et alii, 2001) e a formulação de Prata (1996) tem sido a mais recomendada (ver Capítulo 2.2, item 2).

A Equação 1.4 é preferida também por incluir testes para uma área urbana (NEWTON, 1999 in OFFERLE et alii, 2003). 
Na Eq. 1.4, o parâmetro w é representado pelos valores atmosféricos médios da pressão de vapor $\left(e_{a}\right)$ e de $T_{a}$ na altura da camada superficial de referência (nível da cobertura do veículo, a aproximadamente 1,75 m acima do piso do canyon).

A pressão de vapor (Eq. 1.5) corresponde a uma fração da pressão de vapor de saturação, definida pela umidade relativa (em \%) próxima à superfície $\left(\mathrm{UR}_{\mathrm{a}}\right)$ :

$\mathrm{e}_{\mathrm{a}}=10^{-2} \mathrm{e}_{\mathrm{sa}} \mathrm{UR}_{\mathrm{a}}$

Segundo Bolton (1980), a pressão de vapor de saturação (em hPa) pode ser descrita como função apenas da temperatura do ar em ${ }^{\circ} \mathrm{C}$ :

$\mathrm{e}_{\mathrm{sa}}=6,1078 \exp \left[7,5 \mathrm{~T}_{\mathrm{a}} /\left(237,3+\mathrm{T}_{\mathrm{a}}\right)\right]$

Aplicando-se, portanto, a parametrização, descrita acima, aos valores de temperatura do ar e umidade relativa observados no período do experimento, obtém-se um fluxo de $\mathrm{L}_{\mathrm{a}} \downarrow$ de aproximadamente $385 \mathrm{Wm}^{-2}$, ou seja, da mesma magnitude que os fluxos observados para os setores do percurso com maior obstrução do céu pela vegetação. No entanto, esta parametrização deveria resultar em valores inferiores a $360 \mathrm{Wm}^{-2}$, pois é o que se esperaria a partir das observações, tendo em vista uma situação de céu claro para os setores com menor obstrução do céu.

São consideradas, como se verá na discussão adiante, modificações nos padrões de temperatura e umidade do ar, que possam implicar em alterações de $\mathrm{L}_{a} \downarrow$ parametrizado. Oke (1987) apresenta a poluição atmosférica como um elemento que também pode contribuir para o aumento no fluxo de $L_{a} \downarrow$. O próprio Oke (1981) acaba ressaltando a importância da geometria urbana, em detrimento do fator poluição, como elemento preponderante para o aumento da radiação térmica observada na superfície. No caso do local estudado, por apresentarem os canyons uma relação $A_{o} / A_{l e}$ baixa, talvez o fator poluição não devesse ser desconsiderado em setores com maior visibilidade do céu, ainda mais levada em conta a presença de um anticiclone pré-frontal no período do experimento. 
De fato, Ribeiro e Azevedo (2005) mostram através do mapeamento de concentrações do material particulado total em suspensão na RMSP, que a CUASO apresenta melhor qualidade do ar em relação ao entorno urbano, com concentrações abaixo dos padrões permitidos. Todavia, estas concentrações, como verificam Almeida et alii (2002), não podem ser consideradas desprezíveis, já que é observado, para a localidade da CUASO, um

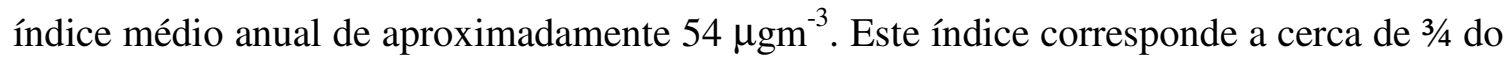
índice médio no entorno imediato e a metade do índice observado nos setores mais poluídos da RMSP.

Deve-se deixar claro que a parametrização aqui aplicada corresponde aos métodos apresentados na literatura, para uma situação de ar limpo, onde apenas o conteúdo de umidade é considerado como contribuinte para as variações nas taxas de $L_{a} \downarrow$. Mas um esforço ainda precisa ser feito para que futuras parametrizações venham considerar a presença dos poluentes atmosféricos, sobretudo em ambientes urbanos, mesmo que nas localidades estudadas as concentrações observadas não mais ultrapassem o limiar prejudicial à saúde.

Realizando, pois, alguns testes de sensibilidade a respeito da formulação apresentada anteriormente, verificou-se que elevações da temperatura do ar implicam também em elevações no fluxo $\mathrm{L}_{\mathrm{a}} \downarrow$ calculado, o que contraria ainda mais as observações sob céu desobstruído. Todavia, considerando-se a temperatura do ar uniforme e reduzindo-se a umidade do ar, até sua total extinção (ar totalmente seco), obteve-se um fluxo $\mathrm{L}_{\mathrm{a}} \downarrow$ de aproximadamente $324 \mathrm{Wm}^{-2}$, inferior aos valores mínimos observados (característicos dos setores com menor, ou muito pouca, obstrução do céu).

Considerando-se, também, um ligeiro aumento da temperatura do ar, da ordem de $0,5^{\circ} \mathrm{C} \mathrm{e}$ uma brusca redução da umidade relativa, em cerca de $20 \%$ (situação extremamente seca, com umidades relativas entre 05 e $10 \%$ ) será possível verificar valores de $\mathrm{L}_{\mathrm{a}} \downarrow$ em torno de $340 \mathrm{Wm}^{-2}$, ou seja, com a mesma magnitude dos valores observados para a situação de céu aberto. 
Vale lembrar que a estação meteorológica fica localizada na pequena depressão radiométrica do máximo indicado por $\mathrm{T}_{12}$ na Figura $6.12 \mathrm{~b}$, ou seja, entre áreas arborizadas. Portanto, considerando-se que as medidas de $L \downarrow$ de intensidade mais baixa provieram de setores asfaltados com pouca ou quase nenhuma vegetação, pareceu razoável assumir uma situação de ar ligeiramente mais aquecido e com reduzida presença de vapor de água, já que há maior impermeabilização do solo e esperaria-se menores taxas de liberação de calor latente nestes setores. $\mathrm{O}$ que condizeria de forma mais fidedigna à realidade sentida pelo pedestre neste ambiente.

\subsubsection{Termos do balanço energético}

Machado e Azevedo (2006b) empregaram relações lineares simples entre as componentes radiativas e o índice NDVI, parametrizadas através de valores observados e estimados por Machado e Azevedo (2005), em uma situação com ângulo zenital solar semelhante ao horário correspondente ao de obtenção das imagens do satélite Landsat. Esta modificação no método original teve como objetivo determinar um ganho radiativo $\left(\mathrm{Q}^{*}\right)$ que fosse representativo da camada entre o piso das vias públicas e as coberturas (topo das árvores e dos edifícios), a qual denomina-se UCL (urban canopy layer), e que, portanto, fosse mais próximo à realidade dos habitantes da cidade.

A estimativa de $Q^{*}$ pode ser segmentada em categorias (MACHADO e AZEVEDO, 2006b) representativas da ocupação do solo. As categorias floresta e arborizado, que apresentam os valores mais baixos de $\mathrm{Q}^{*}$, bem como a categoria espelhos d'água, que apresentam os valores mais elevados de $\mathrm{Q}^{*}$, respondem bem ao aspecto cobertura do solo. Superfícies líquidas, que não apresentam qualquer tipo de sombreamento, são suscetíveis a uma incidência superior da radiação solar.

Seria esperado que $\mathrm{Q}_{\mathrm{E}}$ apresentasse valores significativamente maiores que $\mathrm{Q}_{\mathrm{H}}$ (MACHADO e AZEVEDO, 2006b), em relação ao máximo principal. O fato de $\mathrm{Q}_{\mathrm{E}}$ ser 
ligeiramente inferior a $\mathrm{Q}_{\mathrm{H}}$ ocorre por se considerar o balanço energético sob a perspectiva do nível do pedestre, ou seja, a área sombreada abaixo das copas.

\subsubsection{EFEITO CINEMÁTICO}

A utilização de pirgeômetros, instalados sobre plataformas fixas, requer a aplicação da correção de Fairall et alii (1998). Esta correção visa eliminar o efeito gerado pelo aquecimento diferencial entre a cúpula do sensor e corpo do aparelho, devido ao aquecimento por incidência de radiação solar.

A não aplicação desta correção, sob este tipo de utilização do equipamento, acarreta um acréscimo indesejável nos valores observados em episódios de céu claro e ventos fracos, devido à emissão adicional oriunda da própria cúpula que reveste o sensor, no caso uma termopilha, isso leva, em alguns casos, os pesquisadores a acoplarem sistemas ventilados em torno do corpo do aparelho.

No entanto, mostra-se (MACHADO e AZEVEDO, 2006a), através de relações matemáticas e conceitos físicos simples, que esta correção pode ser desprezada em aplicações do aparelho sobre plataformas móveis. Estimando-se, inclusive, uma velocidade mínima de deslocamento do móvel, capaz de gerar uma ventilação artificial sobre o sensor que aproxime tanto a cúpula, como todo o corpo do aparelho, do equilíbrio térmico com o ar circundante. 


\subsection{O lugar das emissões}

\subsubsection{CARACTERIZAÇÃO TÉRMICA COMPLETA}

Um indivíduo que se desloca pelas ruas de uma cidade está sujeito a trocas de energia. Estas trocas são definidas em grande parte pelos fluxos radiativos. Não apenas pela ação das ondas curtas durante o período diurno, principalmente nos episódios ensolarados. Mas sobretudo, de modo constante, pela ação das ondas longas emitidas pelo meio. E cujo fluxo é resultado do complexo padrão térmico que se estabelece (MACHADO e AZEVEDO, 2006a).

Não são apenas as emissões provenientes da atmosfera ou do piso do canyon que podem interferir sobre a condição climática do indivíduo. Há também a contribuição associada às emissões das paredes dos canyons.

Esta contribuição possui elevada variabilidade espacial, na direção horizontal e também na direção vertical. O campo de visão horizontal de um indivíduo fica, em grande parte das situações, restrito às paredes. Porém, tomando-se amostras do campo de visão vertical (Fig.8.1), sob diversos ângulos de elevação, nota-se que o alvo nem sempre será as paredes. Estes alvos podem se constituir em amostras complexas, mistas, representando uma contribuição relativa entre paredes, atmosfera e até mesmo vegetação.

As emissões urbanas possuem natureza anisotrópica, que pode ser claramente evidenciada através de observações móveis, incluindo-se as paredes dos canyons (VOOGT e OKE, 1998b; MACHADO e AZEVEDO, 2007a).

Medições realizadas por Dubois (1929) já indicavam a influência dos aspectos topográficos sobre a perda radiativa em ondas longas experimentada por um indivíduo (GEIGER et alii, 2003, p. 24-26). Notando-se que as feições típicas, do que décadas adiante os microclimatologistas convencionariam chamar de canyon urbano, eram ainda definidas por 
Dubois como meras feições topográficas. Hoje o canyon urbano é considerado mais um elemento de tipificação da ocupação do solo do que propriamente um elemento topográfico.

A propósito, um indivíduo deslocando-se em uma cidade estará realmente sujeito à variabilidade topográfica entre ruas que representam aclives ou declives ocasionais. Todavia, como as próprias observações de Dubois indicam, a inclinação do horizonte de um indivíduo terá muito menos relevância sobre o fluxo efetivo em ondas longas, do que a geometria das feições que circunscrevem o lugar do indivíduo.

Unsworth e Monteith (1975) sugerem uma distribuição angular do fluxo radiativo em ondas longas $\left(L \downarrow_{\zeta}\right)$, incidente sobre uma superfície, como função do ângulo zenital ( $\zeta$ ), complemento do ângulo de elevação, devido à natureza anisotrópica dos fluxos radiativos (OKE, 1987, p. 354):

$L \downarrow_{\zeta}=\frac{\sigma T^{4}}{\pi}\left[\alpha+\beta \ln \left(\frac{u}{\cos \zeta}\right)\right]$

onde a emissividade $(\varepsilon)$ torna-se função de $u$, a espessura óptica para o vapor de água, função de $T$, a temperatura da cobertura acima do indivíduo, e função de $\alpha$ e $\beta$, determinados empiricamente. Nos casos sob céu aberto, independentemente da nebulosidade, o fluxo $L \downarrow_{\zeta}$ apresentará um valor mínimo em torno da direção zenital, para a qual o parâmetro $u$ é mínimo.

Todavia, para o ambiente urbano, o fator de visão do céu é freqüentemente reduzido e algumas vezes obstruído justamente na direção zenital (OKE, 1987, p. 355). Desse modo, na Eq. 8.1, a temperatura não é necessariamente contribuição apenas do estado térmico do ar ao redor do indivíduo, mas também dos elementos urbanos, como a vegetação, dos veículos e sobretudo das paredes das edificações.

A distribuição horizontal da temperatura das paredes apresenta um distanciamento progressivo da temperatura do ar, resultado da evolução temporal do resfriamento que ocorre em uma taxa superior devido às propriedades térmicas dos materiais (Figuras 8.2 a 8.6). Já na direção de deslocamento é possível perceber padrões de variabilidade da 
temperatura aparente na base do canyon (Figs. 8.7 e 8.8), correspondente à cobertura asfáltica.

Para o caso de um típico canyon urbano, com paredes elevadas, é possível também investigar uma interessante relação térmica para a temperatura no interior do veículo (Figs.8.7 e 8.9) e para a face sul, sombreada.

Com efeito, qual seria, então, o significado das condições ideais de exposição de uma estação de observações climáticas (LINACRE, 1992, p. 29-30), para um indivíduo na cidade? A cobertura asfáltica está longe da considerada ideal. Os obstáculos estão demasiadamente próximos mediante sua dimensão vertical. Sem falar na inexorável estacionariedade. Os topoclimas são característicos dos lugares, e sua observação de modo fixo limita a compreensão de sua diversidade. As características não são em geral homogeneamente advectadas, podendo haver em muitos casos uma área fonte preferencial (ver TARIFA, 1999).

Por estes motivos, os padrões térmicos do que se constituiu em obstáculos, para uma estação fixa, são investigados. É evidente que a condição climática do meio atmosférico interessa. Porém, ela pertence a uma escala superior àquela que é imediatamente relevante ao indivíduo.

Vale ressaltar que modificações da ocupação do solo ao redor de uma estação fixa urbana podem implicar variações em relação aos dados climáticos observados. Indícios de aquecimento ou resfriamento, por exemplo, podem ser falsamente associados a uma aparente modificação climática em escalas superiores àquela da própria ocupação. Medições móveis, por outro lado, contribuem para a desmistificação da origem de tal variabilidade. Podendo, em geral, explicitar esta variabilidade como uma condição já estabelecida há muito na área urbanizada, característica intrínseca dos tipos diversos de ocupação do solo no território da cidade.

As observações móveis realizadas neste estudo não são corrigidas a priori ao efeito da temporalidade. Destacando-se justamente uma situação com variabilidade das condições de 
maior escala e outra na qual tais condições são praticamente invariáveis e restritas à posição solar, representadas pelos experimentos na Av. Paulista e na Av. Pompéia, respectivamente.

O efeito de distanciamento entre as taxas de resfriamento é percebido tanto em uma situação em que a própria temperatura do ar decresce em decorrência dos efeitos da circulação atmosférica em mesoescala (Fig. 8.5b,d), como em uma situação onde a temperatura do ar permanece praticamente inalterada (Fig. 8.5a,c), mas onde há, porém, variabilidade da direção de deslocamento e da ocupação do solo, representadas pela alternância das áreas sombreadas e dos setores com vias arborizadas.

A amplitude térmica maior é percebida entre as temperaturas do ar e das paredes conforme os sensores são rotacionados, elevando-se o ângulo. O que implica uma distribuição vertical aparente da temperatura das paredes, tendendo a valores menores para um ângulo de $45^{\circ}$ (Fig. 8.4c).

Este é um efeito combinado já verificado em outros estudos de campo, com IRTs montados a $30^{\circ}$ e a $45^{\circ}$ (VOOGT e OKE, 1998b, p. 203). Inicialmente, ele se deve à redução do fluxo $L \downarrow$ que atinge a superfície proveniente das paredes mais elevadas dos edifícios, por um padrão misto que compõe o alvo formado em parte por setores de céu aberto. Mas, em contrapartida, também há uma componente de $L \downarrow$ originária do céu por reflexão nas paredes. Os materiais que compõem as paredes são muitas vezes revestimentos de baixa emissividade (ferro oxidado, por exemplo). A reflexão especular, predominante sobre a reflexão difusa no caso de superfícies lisas, também não deveria ser desprezada nesta situação. A emissividade do vidro é muito variável para as ondas longas, tornando a discussão ainda mais complexa para este material em específico. Encontra-se referências da emissividade do vidro desde 0,7 (VOOGT and OKE, 1998b - ver conclusões; ARNFIELD, 1982) a até 0,93 (OKE, 1987, p. 281). Indicando que o vidro não é um emissor necessariamente tão eficiente como poderia-se pensar a priori, em comparação a pedras, paredes escuras, neve fresca, uma floresta de coníferas ou o próprio gelo, por exemplo.

Medições realizadas com sensores IRTs, fabricados pela Apogee Instruments e comercializados pela Campbell Scientific Instruments (CSI), devem ser corrigidas 
linearmente para obtenção de um valor mais próximo à temperatura real $\left(\mathrm{T}_{\mathrm{i}}\right)$ da superfície observada.

A partir da temperatura aparente $\left(\mathrm{T}_{\mathrm{ap}}\right)$ reconhecida pelo sensor termopar de precisão, para o canal infravermelho termal, instalado no corpo do aparelho, deve ser aplicado um conjunto de três coeficientes $(\mathrm{P}, \mathrm{H}$ e $\mathrm{K})$. Estes coeficientes correspondem a três termopares instalados e são relacionados por intermédio de polinômios de segunda ordem à temperatura do corpo do aparelho, que por sua vez necessita de uma temperatura de referência para sua estimativa.

No experimento foi utilizado como temperatura de referência à própria temperatura do ar medida com o sensor RTD. Desta maneira, assim como para outros procedimentos que utilizam sensor infravermelho, como pirgeômetros, por exemplo, instalado sobre plataformas móveis (MACHADO e AZEVEDO, 2006a), o equilíbrio térmico entre o corpo do aparelho e o ar circundante é um fator que corrobora para a realização das medições.

Com base nestas considerações, convém aplicar a seguinte correção para a obtenção da temperatura do alvo:

$T_{i}=T_{a p}-\frac{0.25}{P} \cdot\left[\left(. T_{a p}-H\right)^{2}-K\right]$

O padrão térmico no piso indica alternância da condição de sombreamento, para as ruas dispostas na direção meridional. Na direção zonal este padrão reduz-se consideravelmente, predominando ou uma situação com chão ensolarado ou sombreado por várias horas (Fig.8.8). Isto deve-se fundamentalmente à altura do canyon para a face sul.

A variabilidade da amplitude térmica do chão em relação ao ar, associa-se à amplitude térmica entre as paredes e o ar (Fig. 8.6), considerando-se o posicionamento das paredes por um observador posicionado no interior do edifício, olhando para fora. Em todos os casos há tendência para uma rápida resposta das paredes, em termos de aquecimento, conforme ocorre uma ligeira elevação na temperatura do asfalto, tanto no caso em que os sensores IRTs são posicionados a $0^{\circ}$ (valores elevados), como no caso em que são elevados 
a $30^{\circ}$ ou $45^{\circ}$ (valores inferiores). Com exceção da face sul, sem incidência direta da radiação solar, a tendência de elevação da temperatura é mais lenta. Todavia, um ponto de inflexão ocorre justamente na transição entre os alvos baixos, compostos exclusivamente por paredes, para aqueles compostos por cenas mistas, com presença de céu aberto. No caso das faces leste e oeste esta transição é drasticamente seccionada, entre um setor preferencialmente ensolarado e outro preferencialmente sombreado.

No interior do veículo a relação com a temperatura das paredes elevadas parece indicar uma relação inversa (Fig. 8.9). Há uma associação direta mais consistente com a temperatura do ar. Mas esta associação é muito mais simétrica com a temperatura do piso. Ou seja, para um indivíduo deslocando-se no interior de um veículo, sem ventilação, no caso de um canyon, interessa menos a temperatura das paredes ou mesmo do ar que o preenche, mas sim a condição de variabilidade térmica do piso, do asfalto, pela emissão do fluxo $L \uparrow$. Os padrões não foram tão regulares em outras situações.

O fluxo $L \downarrow$ recebido das paredes, do céu ou das copas das árvores apresentou um padrão próximo do esperado no caso do canyon urbano sem vegetação, tanto para emissão das paredes como da atmosfera (Fig. 8.10). Porém, para as cenas mistas, com paredes elevadas, o fluxo em ondas longas variou muito pouco em termos da variabilidade térmica.

No caso de um canyon arborizado o padrão foi surpreendente, havendo redução do fluxo $L \downarrow$ apesar da temperatura ter se elevado. O padrão esperado prevaleceu no caso das cenas mistas com o sensor a $30^{\circ}$ de elevação, visivelmente seccionado entre setores com maior ou menor contribuição do céu. Esta configuração indica o impacto das largas copas sobre as ruas. Além do sombreamento, à tarde a vegetação apresentou um padrão térmico estabilizado apesar da evolução do aquecimento diurno. A resposta fisiológica da vegetação inibe o aquecimento crescente. Conseqüentemente contribui para a redução proporcional da emissão do fluxo $L \downarrow$ em setores ao redor, através da determinação de um estado térmico de equilíbrio distinto em relação aos setores mais afastados.

O efeito das elevadas emissividades estimadas quando se utiliza como referência as temperaturas aparentes das paredes mais altas, tanto a $30^{\circ}$ como a $45^{\circ}$, explica-se pelo fato 
de as temperaturas aparentes verificadas com os sensores IRTs para ângulos de elevação superiores a $0^{\circ}$ serem gradativamente subestimadas. Para $45^{\circ}$ a emissividade estimada é superior à emissividade estimada com o sensor a $30^{\circ}$. Quanto mais o sensor afasta-se da direção normal ao alvo, menor é a contribuição do fluxo $L \downarrow$. Dado o posicionamento de um sensor, o inverso pode ocorrer quando o alvo está posicionado justamente na direção normal a ele. No caso dos sensores dispostos no plano horizontal, a contribuição maior para o fluxo $L \downarrow$ observado será proveniente dos alvos próximos ao zênite.

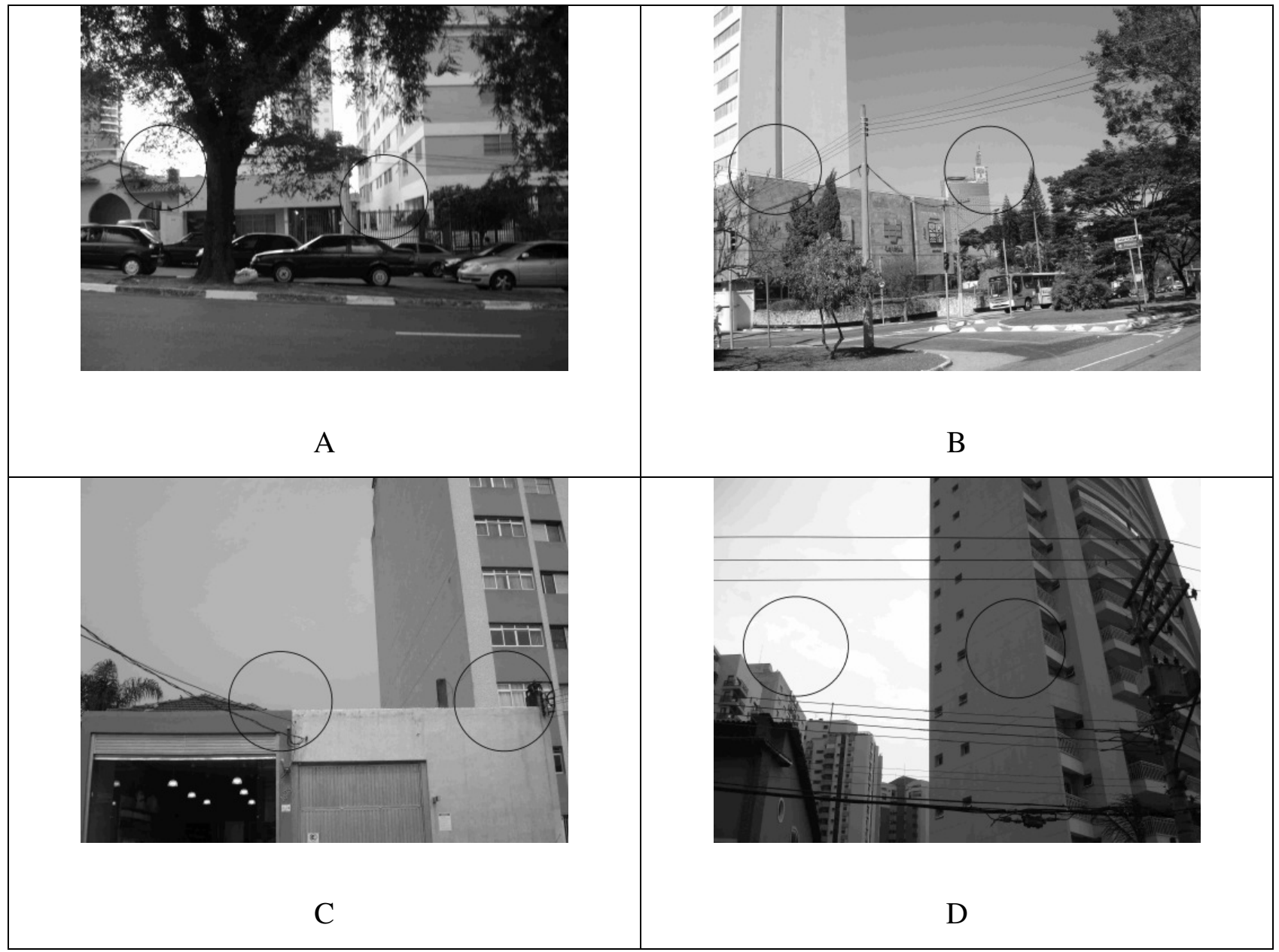

Autor: Antonio Jaschke Machado

Figura 8.1 - Cenas características das paredes de canyons urbanos encontradas durante os experimentos: Av.Pompéia (a), Av. Prof. Frederico Hermann Jr. (b), Rua Tito (c) e Rua Dardanelos (d). Os círculos indicam a área aproximada dos alvos definidos pelo ângulo de abertura do sensor IRT, posicionado em diferentes ângulos de elevação (ver Capítulo 3.3, item 1). 


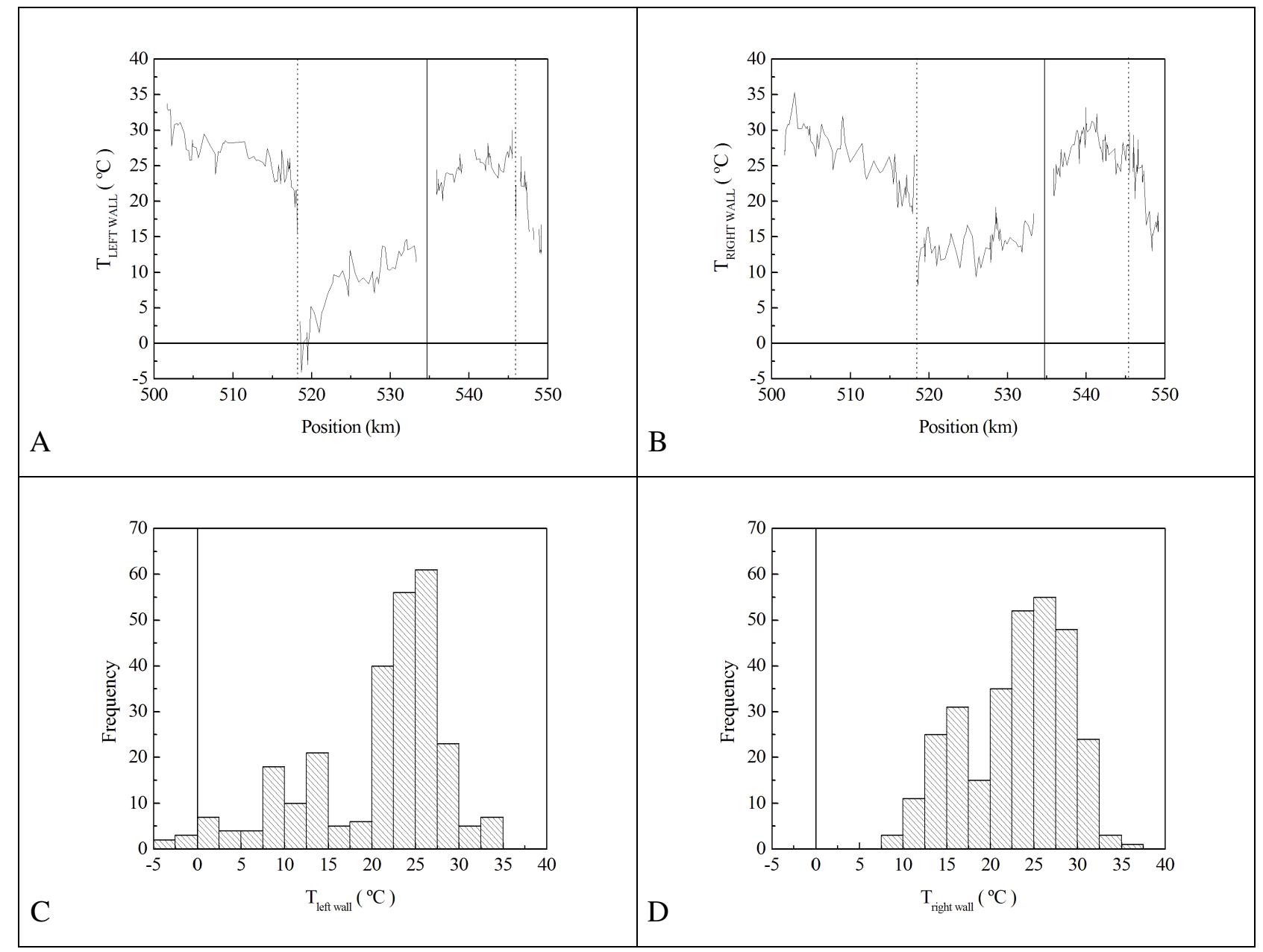

Autor: Antonio Jaschke Machado

Figura 8.2 - Distribuição espacial (a, b) e amostral (c, d) da temperatura das paredes dos canyons obtidas com dois sensores $I R T$, posicionados à direita $(\mathrm{b}, \mathrm{d})$ e à esquerda do veículo $(\mathrm{a}, \mathrm{c})$. A linha vertical contínua $(\mathrm{a}, \mathrm{b})$ delimita dois experimentos realizados em localidades distintas, à esquerda na Av. Paulista e à direita na Av. Pompéia. As linhas verticais pontilhadas delimitam trechos dos experimentos nos quais os sensores IRTs foram posicionados em diferentes ângulos de elevação. 


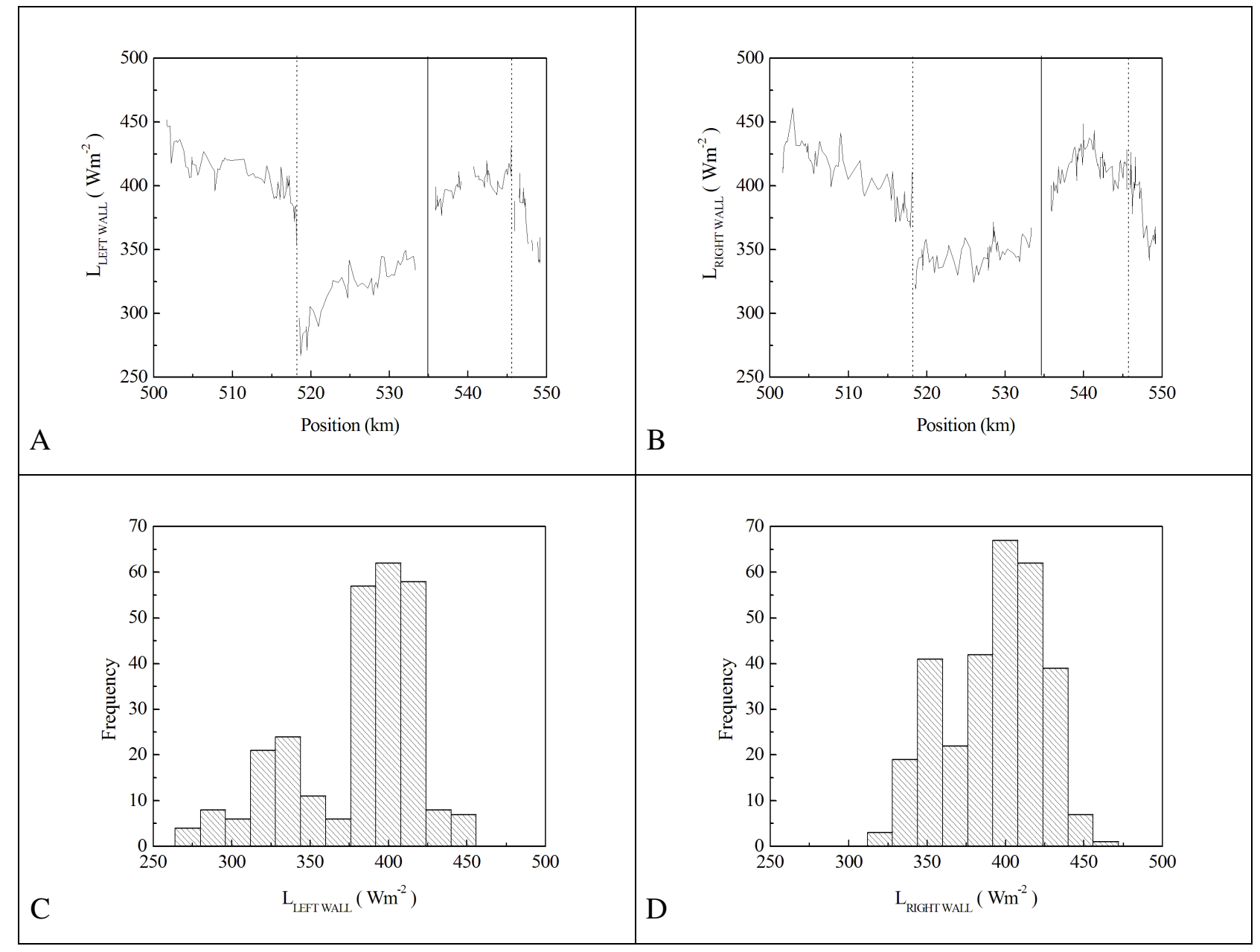

Autor: Antonio Jaschke Machado

Figura 8.3 - Distribuição espacial (a, b) e amostral (c, d) dos fluxos L $\uparrow$ emitidos pelas paredes dos canyons, estimados a partir das observações realizadas com os sensores IRTs posicionados à direita (b, d) e à esquerda do veículo $(a, c)$. A linha vertical contínua $(a, b)$ delimita dois experimentos realizados em localidades distintas, à esquerda na Av. Paulista e à direita na Av. Pompéia. As linhas verticais pontilhadas delimitam trechos dos experimentos nos quais os sensores IRTs foram posicionados em diferentes ângulos de elevação. 

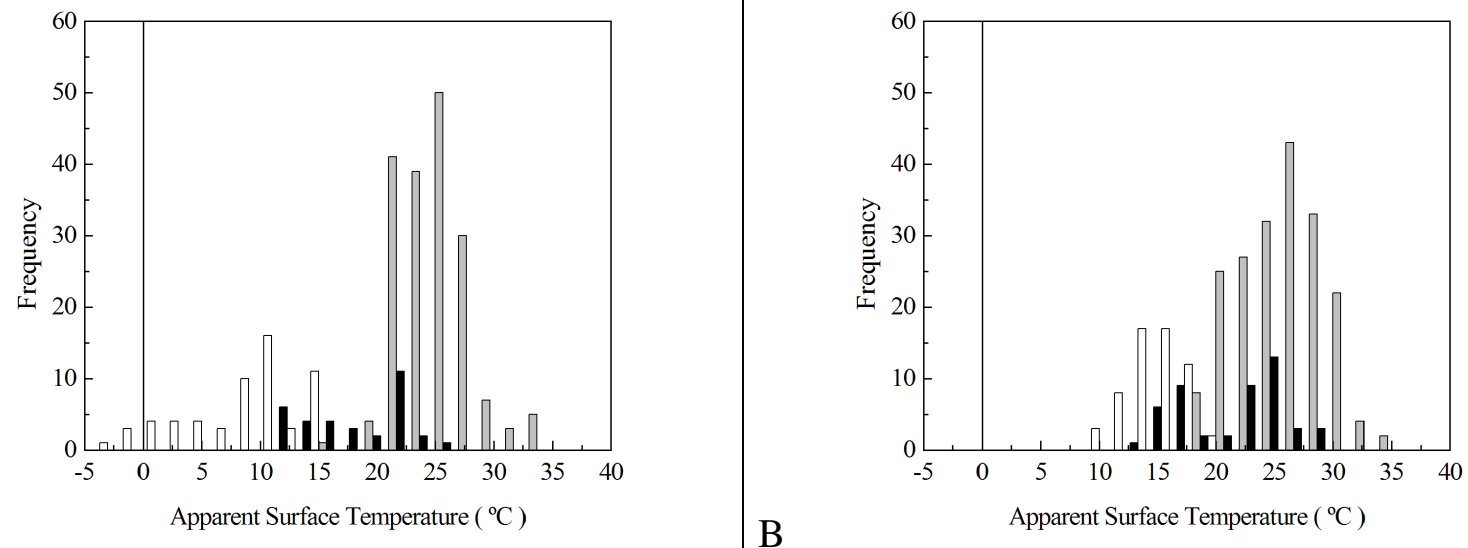

A

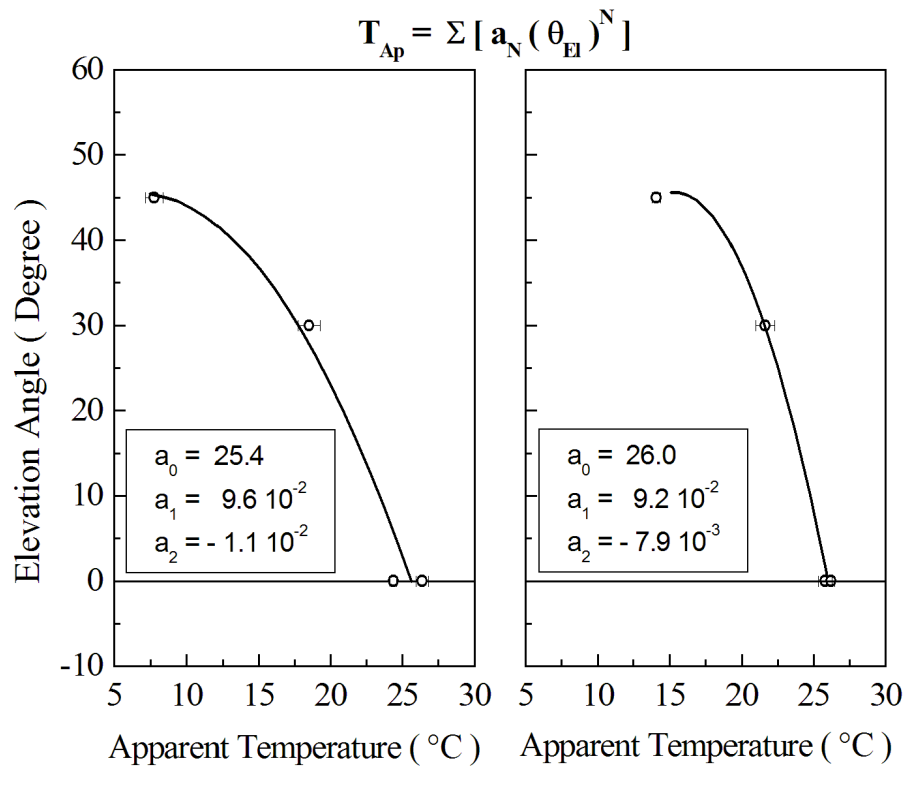

Autor: Antonio Jaschke Machado

Figura 8.4 - Distribuição amostral da temperatura aparente das paredes dos canyons obtidas com os sensores IRTs posicionados à direita (b) e à esquerda (a). As colunas cinzas indicam o sensor posicionado a um ângulo de elevação de $0^{\circ}$, as pretas a $30^{\circ}$ e as brancas a $45^{\circ}$. Distribuição vertical (c) da temperatura média aparente, as barras indicam o erro relativo e as linhas contínuas sugerem um polinômio de segunda ordem que melhor representa esta distribuição. 


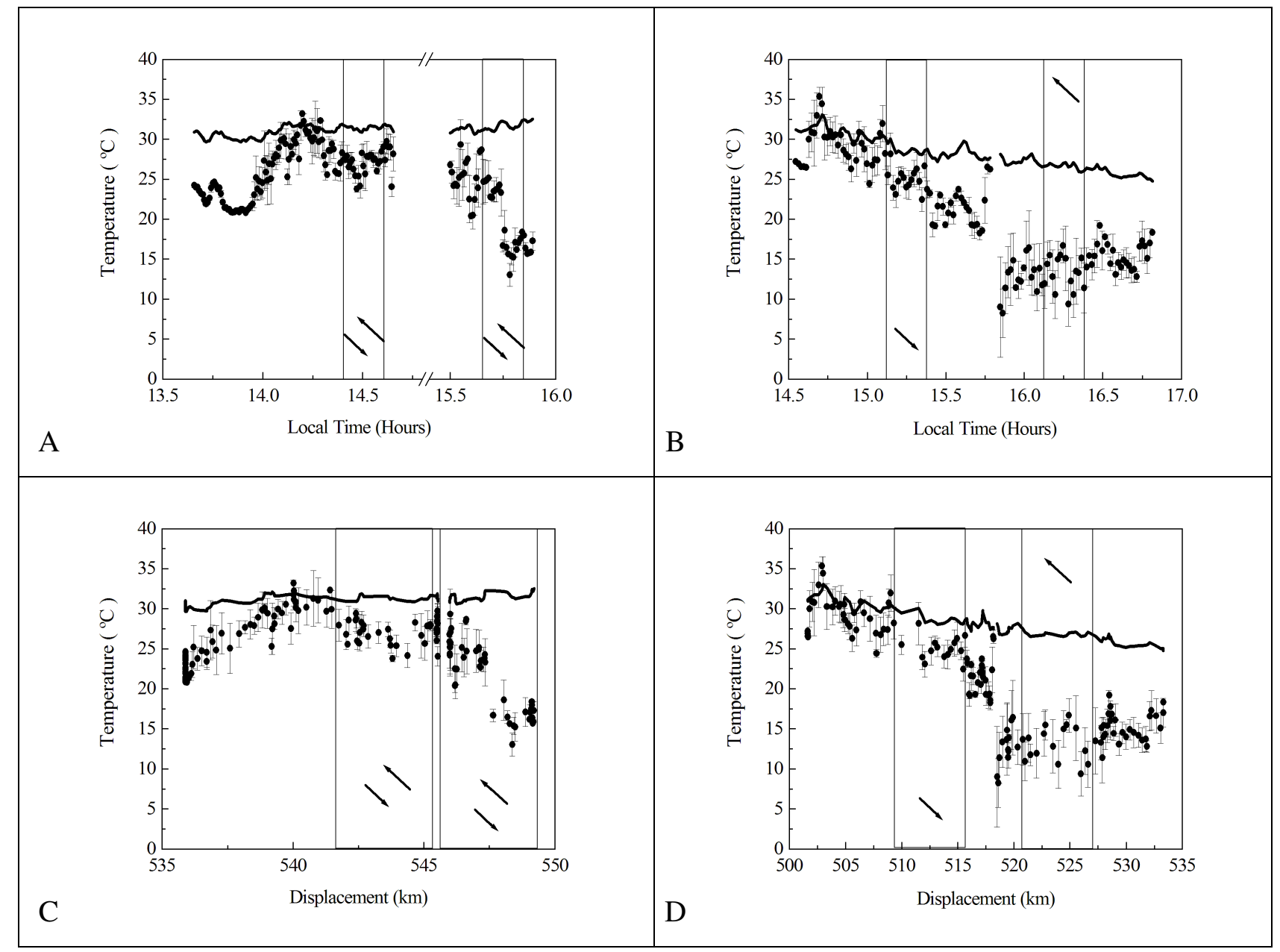

Autor: Antonio Jaschke Machado

Figura 8.5 - Distribuição temporal (a, b) e espacial (c, d) da temperatura média das paredes dos canyons durante o experimento na Av. Paulista (b, d) e o experimento na Av. Pompéia (a, c). As barras de erro indicam o desvio padrão. As linhas contínuas escuras representam a temperatura do ar observada durante os experimentos. As linhas verticais definem os trechos compreendidos pelas Avenidas. As setas indicam o sentido de deslocamento nestas vias. 

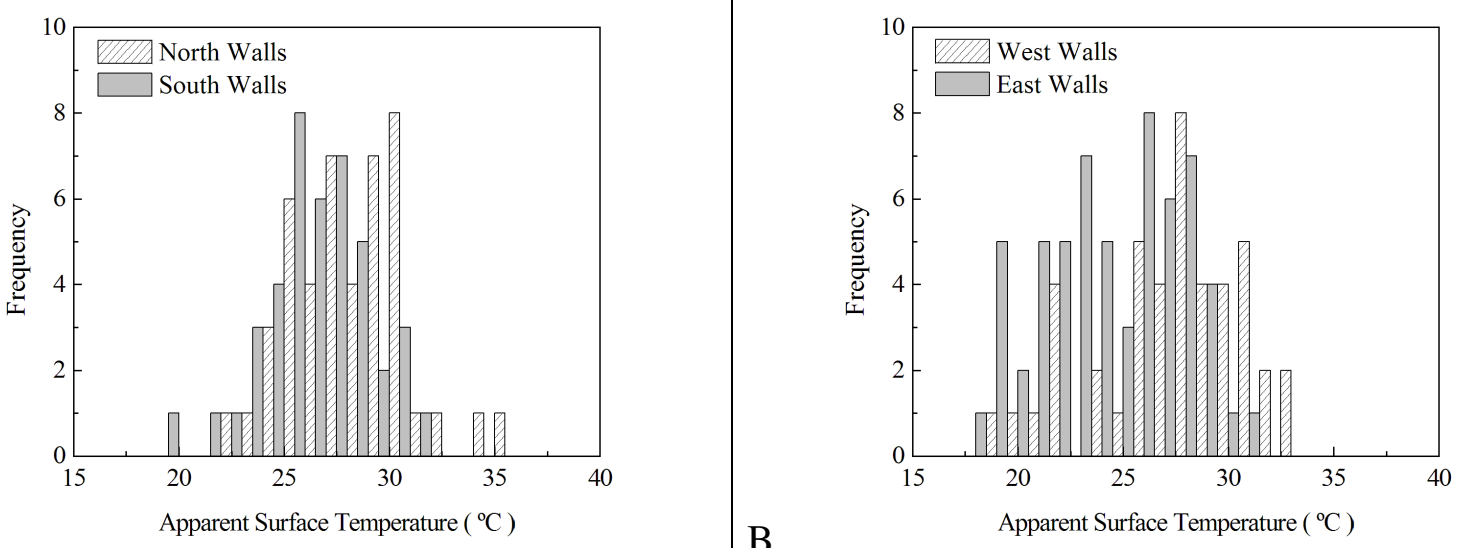

A

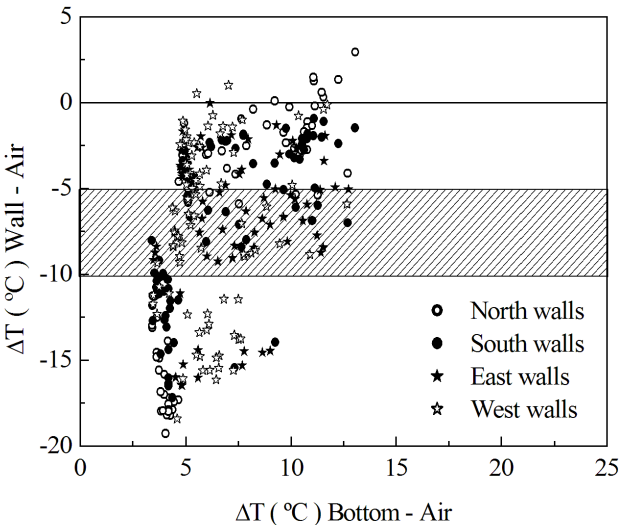

C

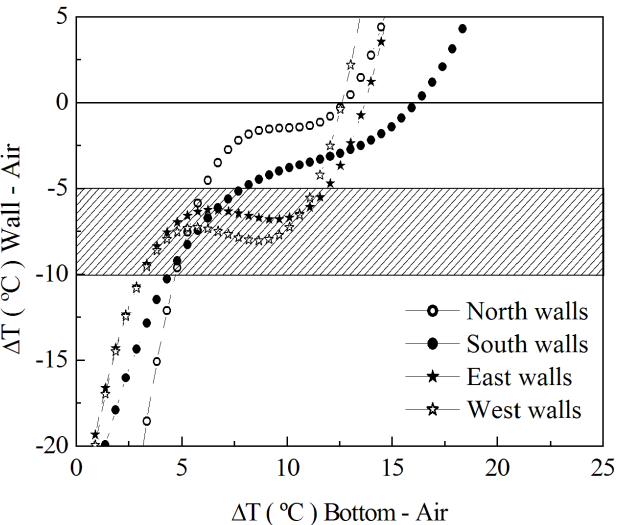

$\mathrm{D}$

Autor: Antonio Jaschke Machado

Figura 8.6 - Distribuição amostral da temperatura aparente das paredes, para os canyons posicionados na direção zonal (a) ou na direção meridional (b). Distribuição da amplitude térmica entre as paredes e o ar em relação à amplitude térmica entre o piso do canyon e o ar (c), sugerindo-se os perfis polinomias que melhor se adequam a estas distribuições (d). A distribuição cardeal das paredes é referenciada por um observador imaginário posicionado no interior do edifício, que observa para além das janelas. As áreas hachuradas (c, d) representam o intervalo onde prevalecem as cenas mistas entre paredes e céu. 


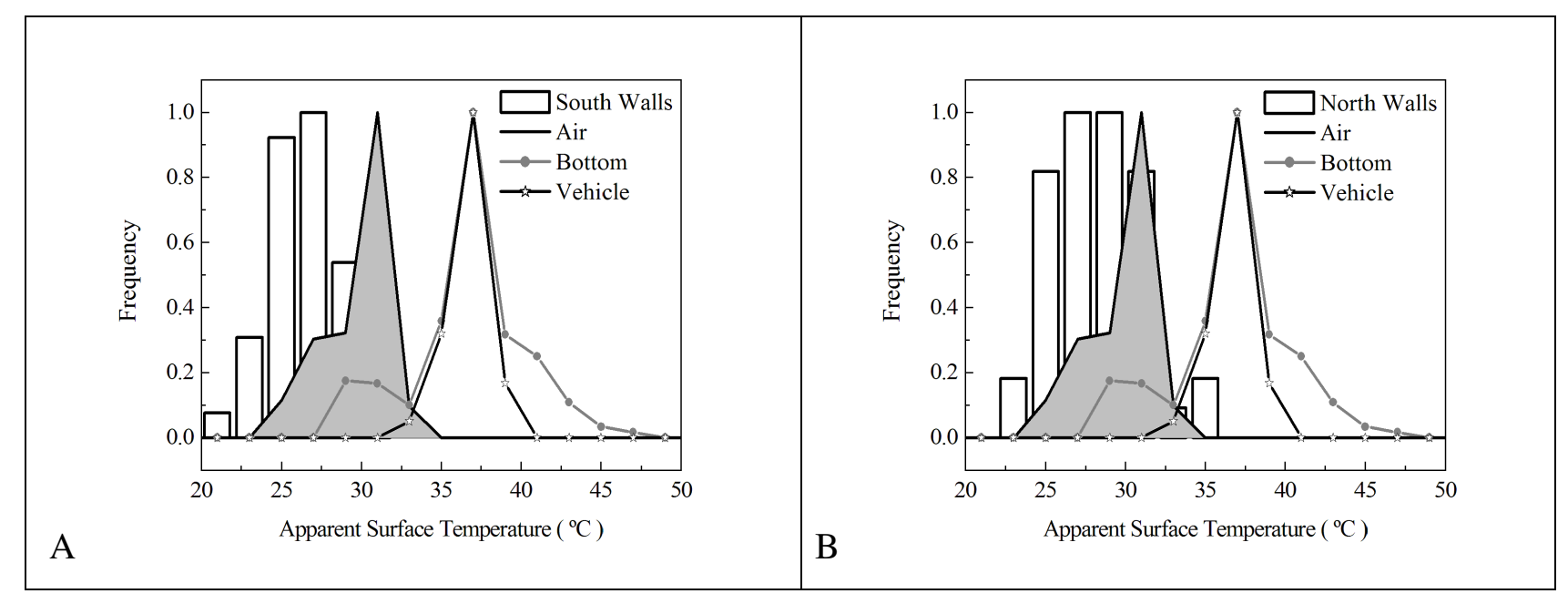

Autor: Antonio Jaschke Machado

Figura 8.7 - Distribuição amostral da temperatura do ar, do piso, no interior do veículo e sobre a superfície das faces sul (a) e norte (b).

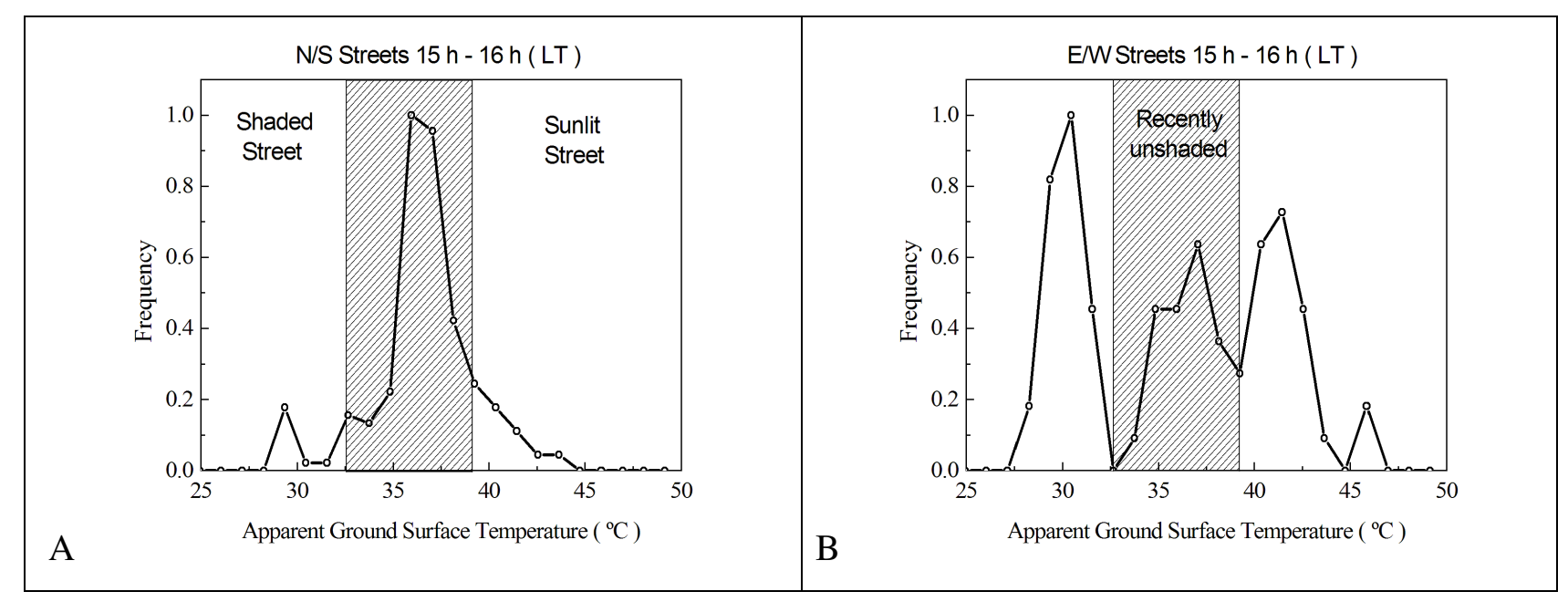

Autor: Antonio Jaschke Machado

Figura 8.8 - Distribuição amostral da temperatura aparente do piso dos canyons meridionais (a) e zonais (b). 


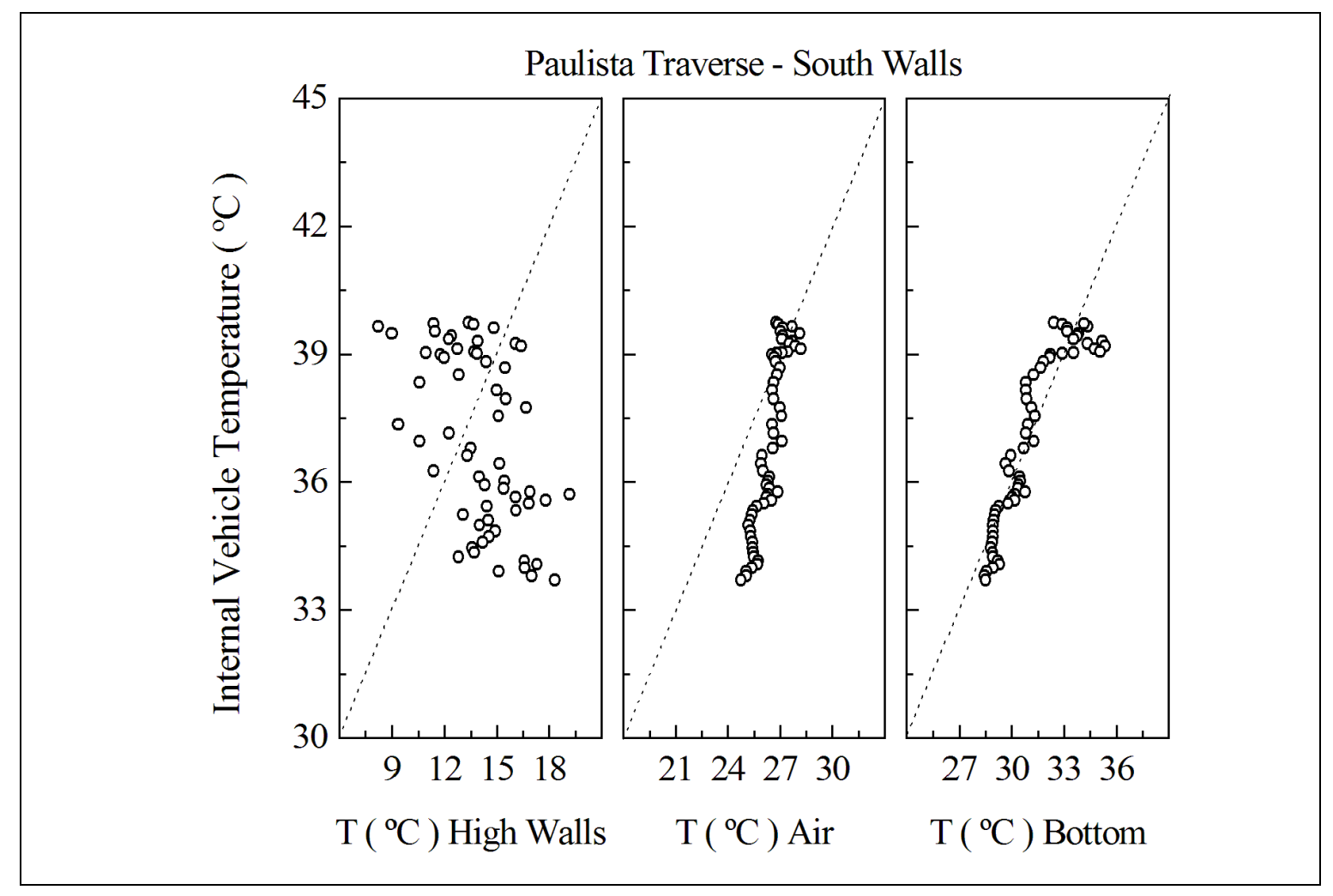

Autor: Antonio Jaschke Machado

Figura 8.9 - Distribuição da temperatura observada no interior do veículo em relação à temperatura das paredes mais altas (esquerda), à temperatura do ar (centro) e à temperatura do piso (direita). As linhas pontilhadas indicam a correlação linear perfeita. 


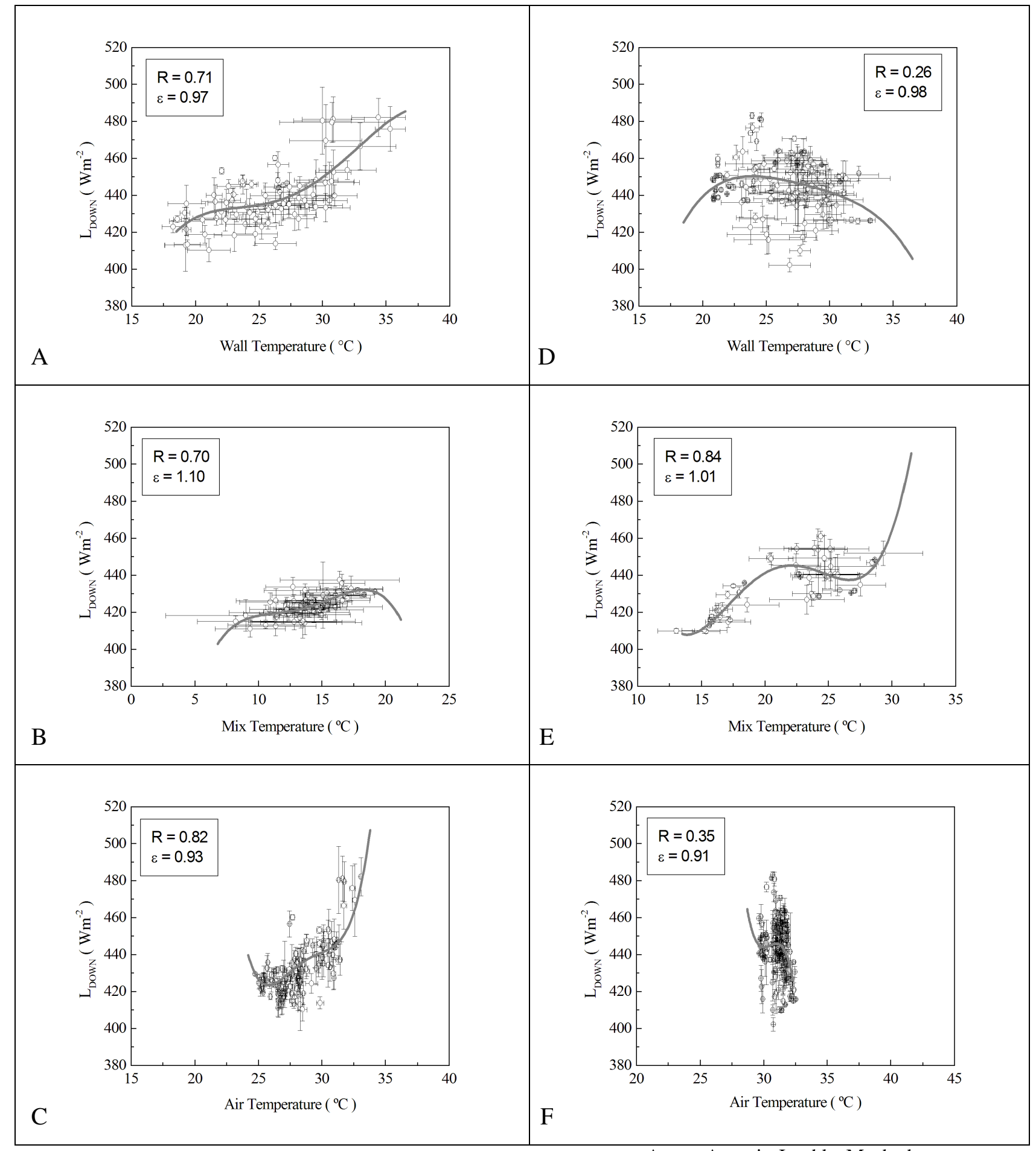

Autor: Antonio Jaschke Machado

Figura 8.10 - Distribuição do fluxo L $\downarrow$ médio em relação à temperatura das paredes (a, d), das cenas mistas (b, e) e do ar (c, f), observado durante os experimentos na Av. Paulista (a, b, c) e na Av. Pompéia (d, e, f). As barras representam o desvio padrão. As linhas contínuas indicam os polinômios de quarta ordem que melhor se ajustam. Os índices de correlação são representados por $\mathrm{R}$ e as emissividades estimadas por $\varepsilon$. 


\subsubsection{ANÁLISE EM TOPOESCALA}

\subsubsection{Umidade}

A partir do momento em que são consideradas as unidades de ocupação do solo em topoescala, pode-se definir áreas onde predominam as construções baixas, vias mais largas e com pouco ou nenhuma arborização. Estas áreas possuem um fator de visão do céu elevado, possibilitando que o fluxo L $\downarrow$ observado em setores com esta característica seja altamente representativo das condições atmosféricas.

Desse modo, conhecendo-se a temperatura do ar, é possível aferir através de alguma dentre as muitas relações paramétricas encontradas na literatura uma estimativa razoável para o conteúdo de umidade no ar. Estas estimativas, que devem constituir uma etapa seguinte a este projeto inicial, poderão ser averiguadas através de medições da umidade relativa do ar em complementação aos resultados atingidos até o momento.

Por este motivo, foi adquirido o sensor de umidade Vaisälä, modelo HMP 50UBB3A1X. Este sensor é compatível com o micrologger CR3000 da Campbell e deve fazer parte da plataforma móvel, com seu sinal sendo adquirido simultaneamente aos demais ou mesmo em experimentos individuais exclusivos para averiguação da condição de umidade nas áreas já cobertas pelos experimentos anteriores. 


\subsubsection{Fluxos distribuídos climaticamente}

A análise topoescalar dos termos do balanço de energia $\left(L^{*}, Q^{*}\right.$ e $\left.Q_{H}\right)$ e da pressão de vapor estimada (e) através da expressão de Brunt (GEIGER et alii, 2003), pode ser aperfeiçoada considerando-se imagens remotas como as do satélite SPOT.

\subsubsection{Classificação}

Com o intuito de distribuir relativamente aos tipos de ocupação do solo, foi idealizada e apresentada a seguir uma classificação em termos desta, mediante a topologia aplicada por Tarifa e Armani (2001) para a grande unidade climática urbana central. Dessa maneira, destacam-se quatro tipos característicos de ocupação do solo: o verticalizado (Fig. 8.11), o bairro verde (Fig. 8.12), o industrial (Fig. 8.13) e o residencial com predomínio de edificações baixas (Fig. 8.14).

A partir das distribuições, são finalmente caracterizados os fluxos radiativos em termos destas ocupações do solo (Tab. 8.1). 


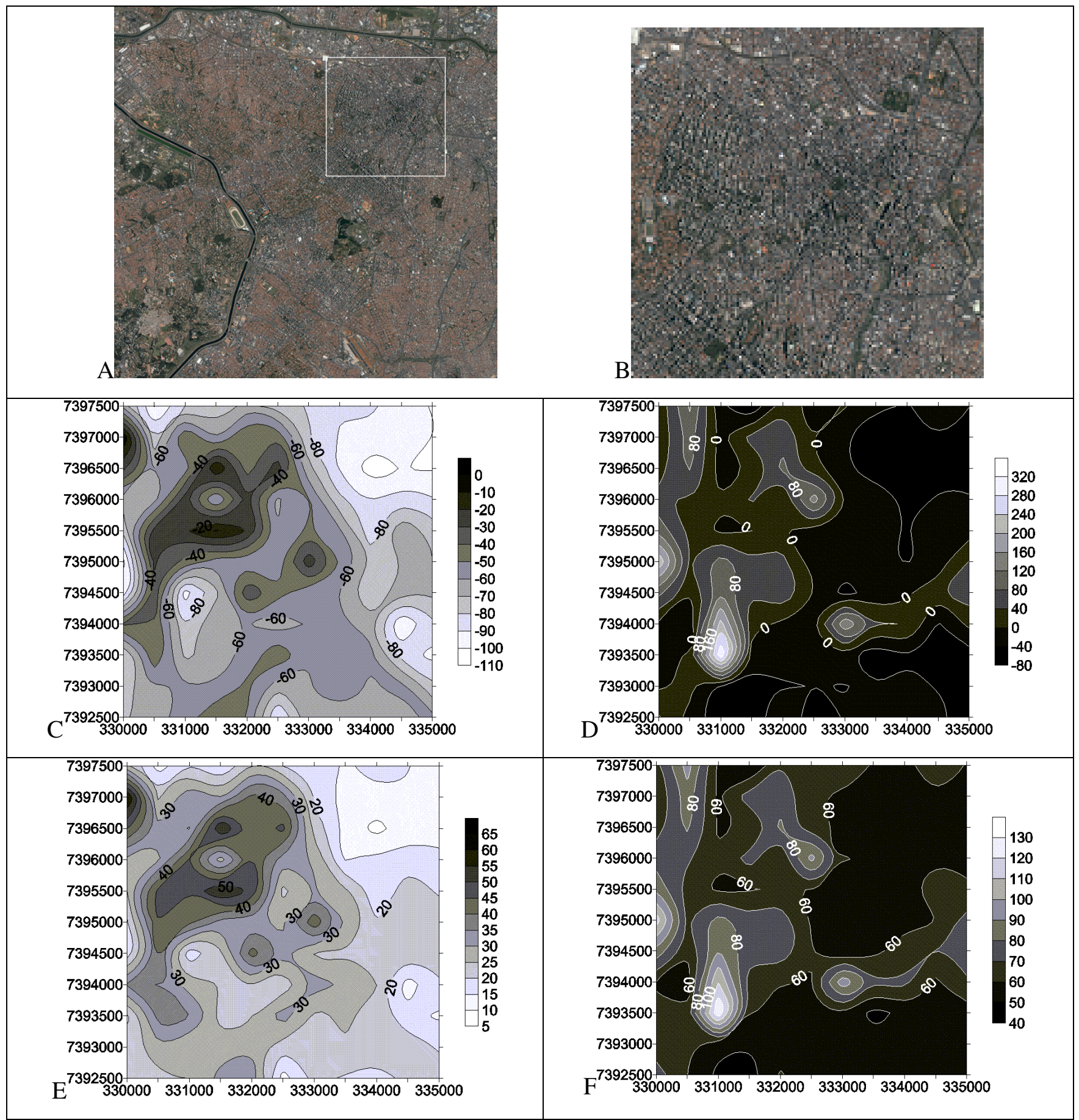

Autor: Antonio Jaschke Machado

Figura 8.11 - Imagem SPOT do município de São Paulo (a). O polígono branco delimita a região central da cidade (b). Distribuição espacial dos fluxos $\mathrm{L}^{*}$ (c), $\mathrm{Q}^{*}$ (d) e $\mathrm{Q}_{\mathrm{H}}$ (e) em $\mathrm{Wm}^{-2}$, e da pressão de vapor (f) estimada em hPa. 


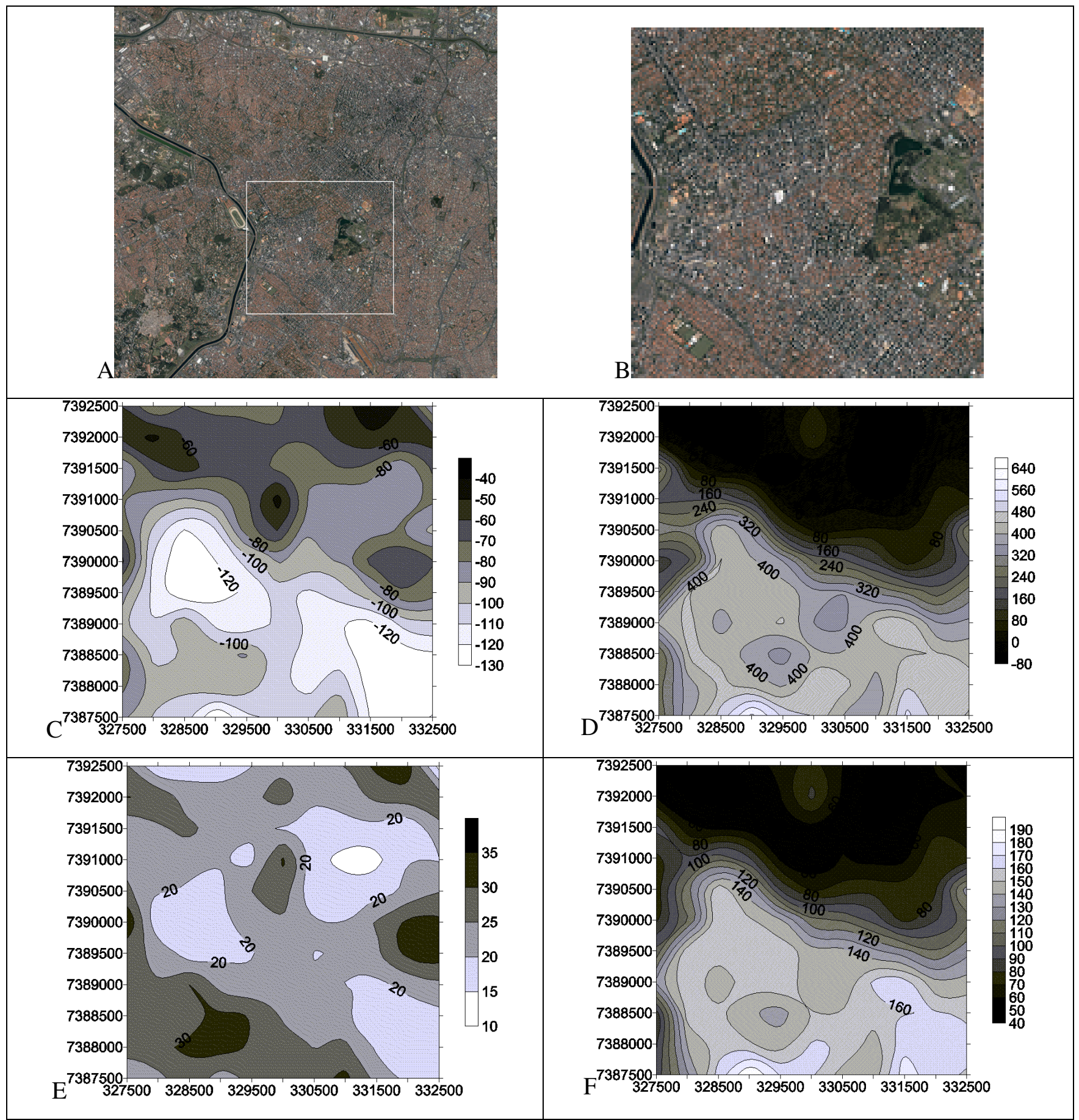

Autor: Antonio Jaschke Machado

Figura 8.12 - Imagem SPOT do município de São Paulo (a). O polígono branco delimita a região do Parque do Ibirapuera e Jardins em direção à várzea do Pinheiros (b). Distribuição espacial dos fluxos L* (c), Q* (d) e $\mathrm{Q}_{\mathrm{H}}(\mathrm{e})$ em $\mathrm{Wm}^{-2}$, e da pressão de vapor (f) estimada em $\mathrm{hPa}$. 


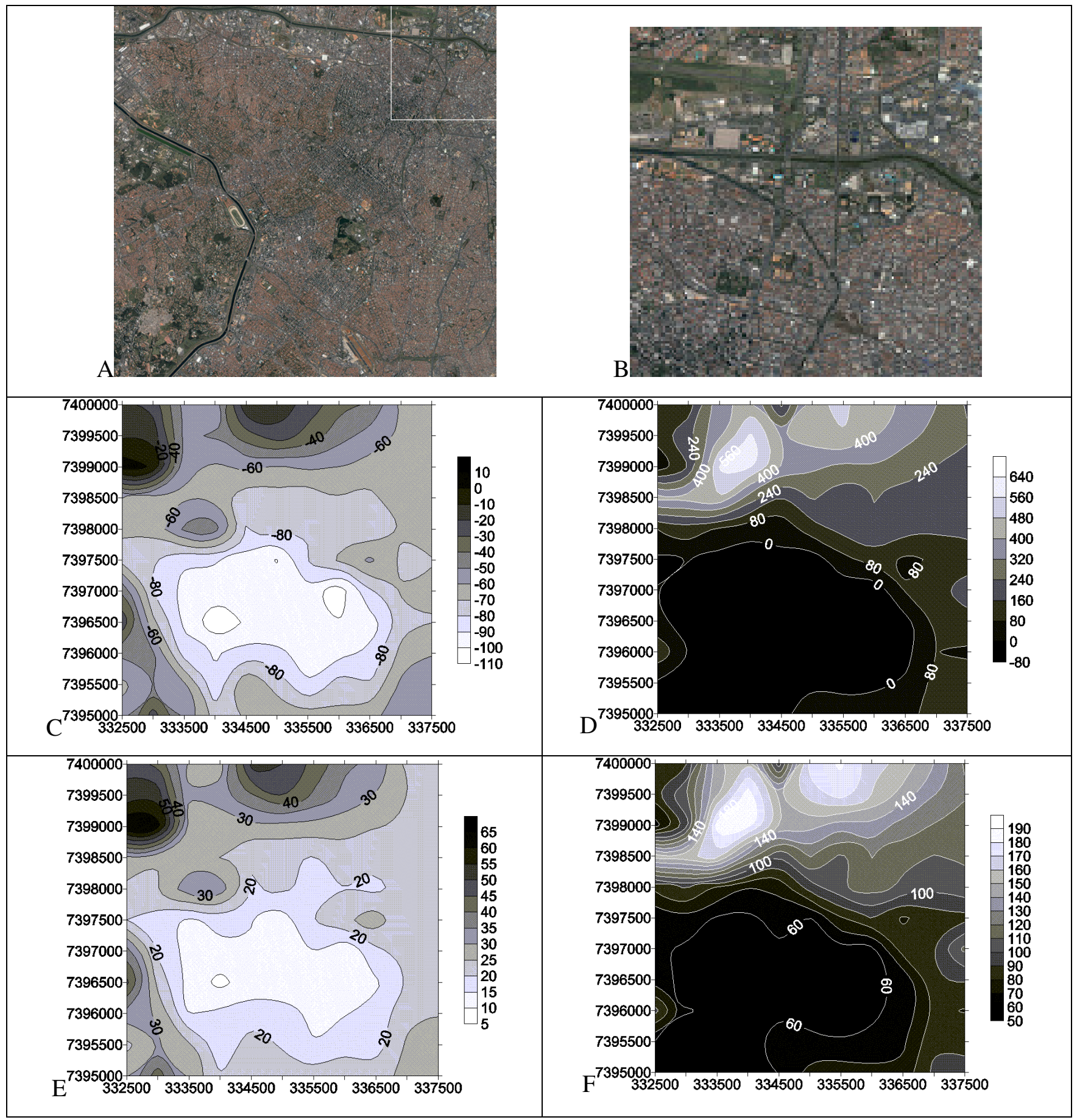

Autor: Antonio Jaschke Machado

Figura 8.13 - Imagem SPOT do município de São Paulo (a). O polígono branco delimita a região da Marginal Tietê que abrange a confluência do Tamanduateí em direção à várzea do Carmo (b). Distribuição espacial dos fluxos $\mathrm{L}^{*}(\mathrm{c}), \mathrm{Q}^{*}$ (d) e $\mathrm{Q}_{\mathrm{H}}(\mathrm{e})$ em $\mathrm{Wm}^{-2}$, e da pressão de vapor (f) estimada em $\mathrm{hPa}$. 


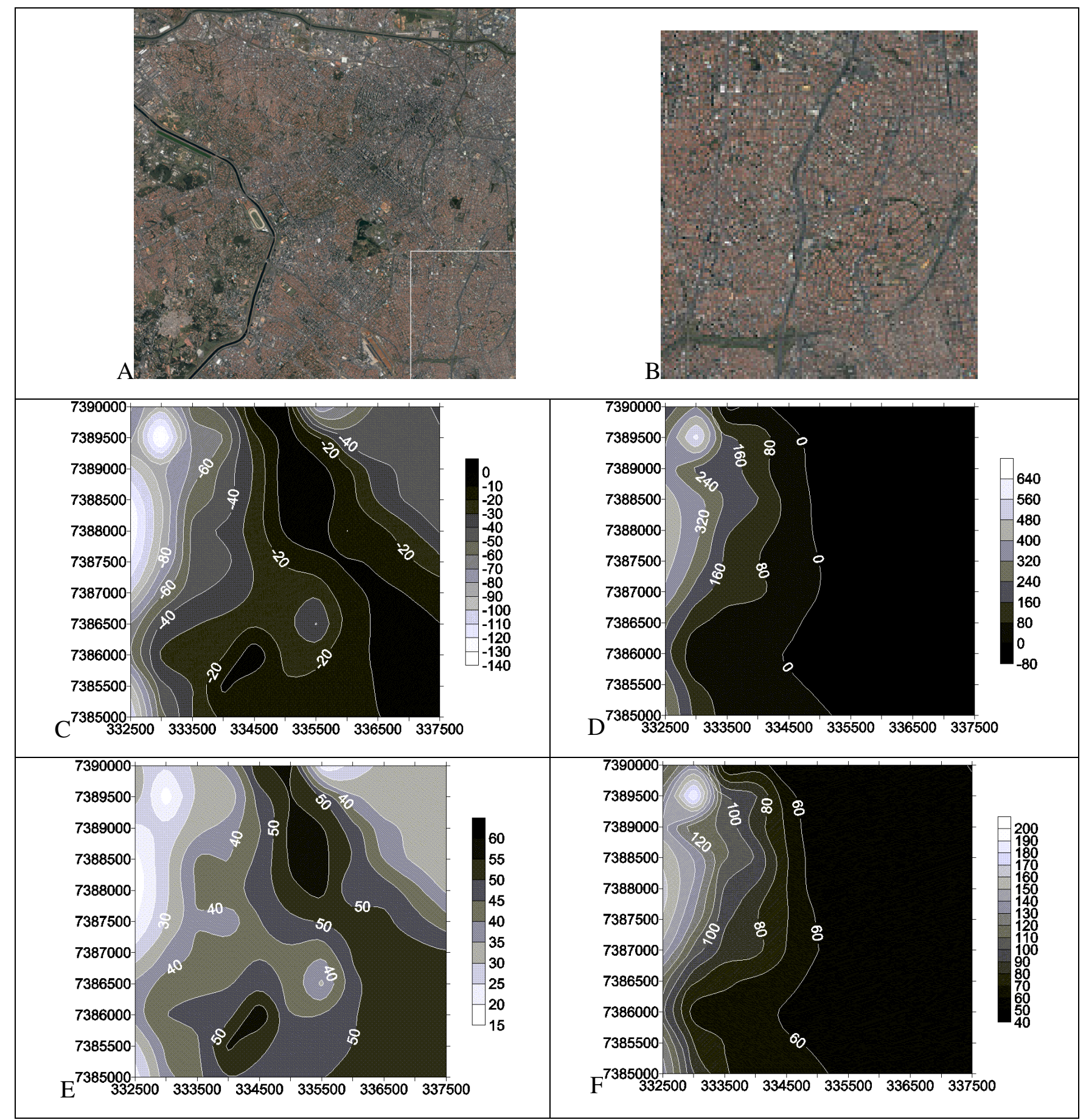

Autor: Antonio Jaschke Machado

Figura 8.14 - Imagem SPOT do município de São Paulo (a). O polígono branco delimita a região do Jabaquara, abrangendo o entruncamento com a Av. dos Bandeirantes ao sul e estendendo-se a leste pelos bairros do Ipiranga e da Saúde (b). Distribuição espacial dos fluxos L* (c), Q* (d) e $\mathrm{Q}_{\mathrm{H}}(\mathrm{e})$ em Wm ${ }^{-2}$, e da pressão de vapor (f) estimada em hPa. 
Tabela 8.1 - Fluxos L* (onda longa), Q* (multiespectral) e K* (onda curta) médios observados e estimados, acompanhados dos respectivos erros relativos e associados a diferentes tipos de ocupação do solo.

\begin{tabular}{|c|c|c|c|c|}
\hline & Verticalizado & Bairro Verde & Industrial & Residencial \\
\hline $\mathrm{L}^{*}{ }_{\mathrm{M}}\left(\mathrm{Wm}^{-2}\right)$ & $-56,9$ & $-79,3$ & $-79,3$ & $-33,3$ \\
\hline $\mathrm{L}^{*}{ }_{\mathrm{RE}}$ & $0,7(1,2 \%)$ & $1,8(2,3 \%)$ & $0,9(1,1 \%)$ & $2,8(8,4 \%)$ \\
\hline $\mathrm{Q}^{*}{ }_{\mathrm{M}}\left(\mathrm{Wm}^{-2}\right)$ & $-0,7$ & 137,7 & 72,1 & 73,0 \\
\hline $\mathrm{Q}^{*}{ }_{\mathrm{RE}}$ & $2,1(300,0 \%)$ & $14,1(10,2 \%)$ & $5,4(7,5 \%)$ & $13,4(18,4 \%)$ \\
\hline $\mathrm{K}^{*}{ }_{\mathrm{M}}\left(\mathrm{Wm}{ }^{-2}\right)$ & 56,2 & 217,0 & 151,4 & 106,3 \\
\hline $\mathrm{K}^{*}{ }_{\mathrm{RE}}$ & $2,4(4,3 \%)$ & $15,6(7,2 \%)$ & $5,7(3,8 \%)$ & $16,0(15,1 \%)$ \\
\hline
\end{tabular}

Autor: Antonio Jaschke Machado 


\subsubsection{Estudo de caso}

A análise escalar pode ser aprofundada para escalas inferiores àquelas típicas da topoescala, aproximando-se mais ainda da realidade do indivíduo na cidade e dos próprios limites do método aplicado.

O banco de dados constituído abre inúmeras possibilidades de estudo de casos particulares no interior da área metropolitana, como já tem sido explorado em Machado e Azevedo (2004, 2005, 2006a, 2007a) e em algumas seções desta tese (ver, por exemplo, item 3.2.1). Com a finalidade de ainda ilustrar uma destas possibilidades, será apresentado a seguir o caso da Avenida Queiroz Filho (Fig. 8.15) situada na Zona Oeste da cidade de São Paulo.

Este caso da Queiroz Filho é apresentado, por reunir uma série de fatores que corroboram para uma compreensão didática do fenômeno. Dentre estes fatores vale citar, disponibilidade de imagem orbital do setor, satisfatório levantamento fotográfico para identificação de elementos da paisagem, observações conjuntas dos fluxos radiativos e das temperaturas das paredes em horários e dias da semana distintos e com sensores distintos, particularidade do posicionamento astronômico com o eixo da Avenida ocupando uma direção muito próxima à zonal (oeste-leste), em torno do qual oscila uma trajetória quase perfeitamente senoidal com as faces constituidoras das paredes do canyon voltadas para todas as direções possíveis, entre outros, como a própria variabilidade de tipos de ocupação do solo.

Este trajeto de cerca de $1,5 \mathrm{~km}$ foi percorrido em torno de cinco ou seis vezes, sendo possível identificar sua localização em torno das coordenadas $7396.10^{3}$ UTM - lat e $324.10^{3}$ UTM - lon (ver ficha EM-1 em Anexo 2). Foram escolhidas a manhã do dia 22 de abril de 2007, um domingo de outono, e a noite do dia 15 de agosto de 2007, uma quarta-feira de inverno. Ambas situações de céu claro, porém, com distintos padrões de umidade. $\mathrm{O}$ dia 22 foi um dia típico da estação úmida, com pancadas de chuva à tarde, enquanto o dia 15 foi um dia típico da estação seca, com ar poluído e sem evolução de brisa marítima.

O trajeto foi percorrido em ambas situações no sentido B para A (ver Fig. 8.15), através de um suave aclive, pouco mais acentuado ao fim do percurso. A ocupação do solo oscila 
entre um arco inicial constituído por empreendimentos comerciais nas duas faces do canyon e poucas árvores, e um arco posterior com face norte bastante recuada, face sul próxima à via e totalmente murada, além de intensamente arborizado, sobretudo, com copas bastante largas.

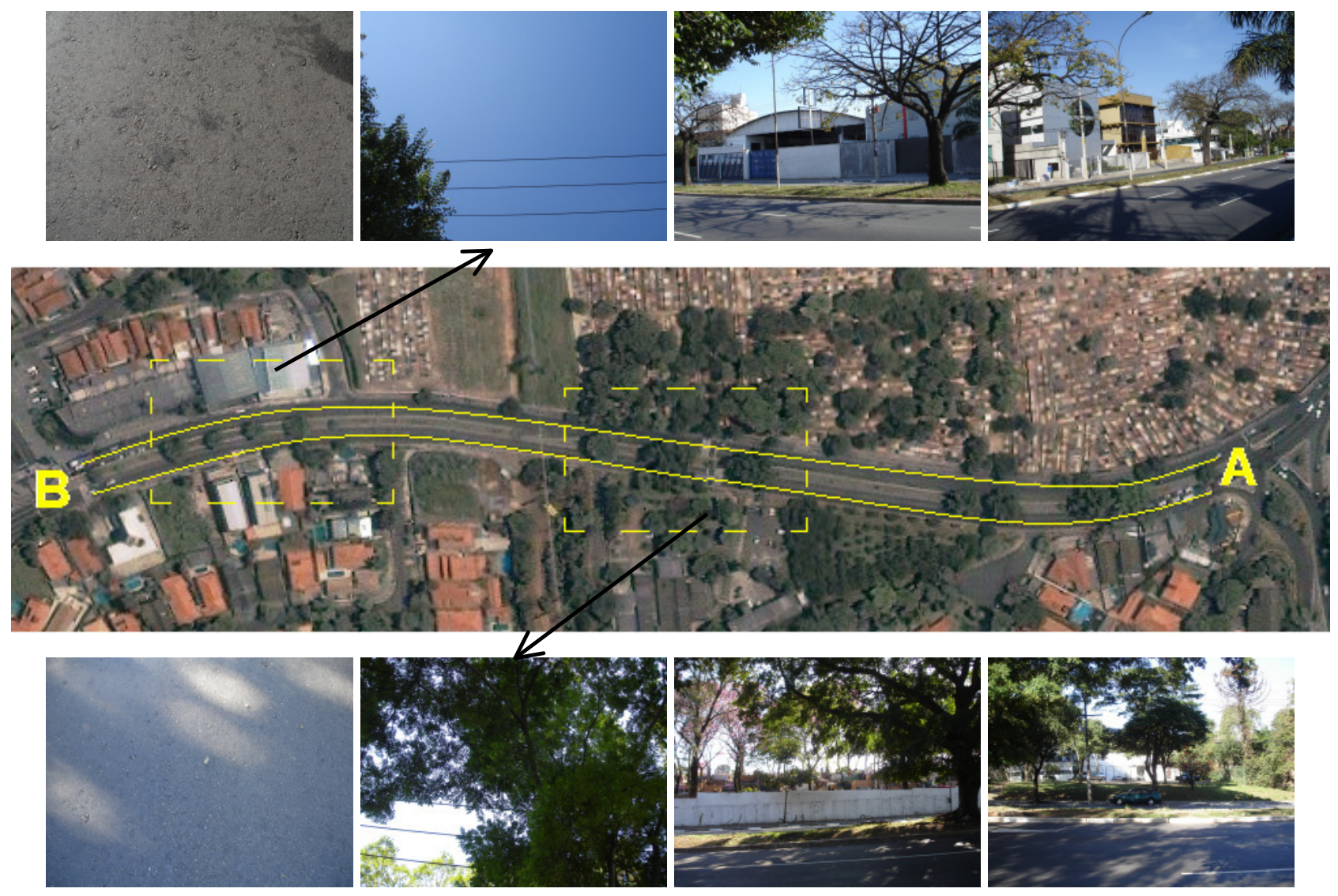

Autor: Antonio Jaschke Machado

Figura 8.15 - Imagem SPOT da área em torno à Av. Queiroz Fo. (centro), entre a Av. Diógenes Ribeiro de Lima (A) e a Av. Imperatriz Leopoldina (B). As linhas contínuas representam os trajetos percorridos e correspondem às pistas norte e sul. Os polígonos tracejados delimitam dois setores com ocupações distintas, ao setor oriental correspondem as imagens adjacentes abaixo, enquanto ao setor ocidental correspondem as imagens adjacentes acima. As imagens acima e abaixo também possuem uma correspondência mútua, da esquerda para a direita representam respectivamente a visão do nadir, a visão do zênite, a visão da face sul e a visão da face norte. 
Através destes dois arcos constituidores do trajeto, são revelados interessantes padrões de fluxos que compõem o balanço radiativo (Fig. 8.16) e de temperaturas das paredes do canyon (Fig. 8.17).

O balanço radiativo diurno é positivo, enquanto o balanço radiativo noturno é negativo, basicamente efeito do aquecimento solar no primeiro caso (ver curva no alto da Fig. 8.16). Sendo mais pronunciado no primeiro setor do percurso onde uma visão mais ampla do céu permite o aquecimento superficial mais pronunciado.

Considerando apenas o balanço em ondas longas, nota-se uma quase similaridade entre a situação diurna e a situação noturna. Sendo a situação noturna ligeiramente mais pronunciada no sentido negativo para o primeiro setor. Uma visão mais ampla do céu acaba implicando também uma maior taxa de resfriamento noturno por perda radiativa.

É curioso notar que, apesar da maior variabilidade média se manifestar nos fluxos $\mathrm{K}^{*}$ e $\mathrm{Q}^{*}$ (oscilam cerca de $40 \mathrm{Wm}^{-2}$ entre o máximo e o mínimo), é no fluxo $\mathrm{L}^{*}$ que se manifesta a maior variabilidade relativa, oscilando cerca de $30 \mathrm{Wm}^{-2}$ para a mesma localidade, isto é, quase $80 \%$ da variabilidade média (!) - ver barras de desvio padrão na Figura 8.16.

Em relação à temperatura das paredes do canyon (Fig. 8.17), verifica-se em linhas gerais um equilíbrio muito próximo à temperatura do ar, sobretudo, na situação diurna. Na situação noturna as paredes tendem a se tornar ligeiramente mais frias, de um modo geral. Destacando-se, no entanto, o primeiro setor (extremo oeste na Fig. 8.17) onde as paredes chegam a estar entre 4 e $6^{\circ} \mathrm{C}$ mais frias do que o ar.

Alguns máximos merecem destaque (note os dois picos na Fig. 8.17, acima). Tanto no extremo oeste como no extremo leste do percurso há presença de paredes, cerca de $12^{\circ} \mathrm{C}$ a $6^{\circ} \mathrm{C}$ mais aquecidas do que o ar. Trata-se da parede de um galpão e do muro de um cemitério dispostos ambos com faces sudeste, e que, portanto, já estão mais expostos há algum tempo a raios solares matutinos. 
Além disso, há também o declínio verificado entre máximos (Fig. 8.17, abaixo) no segundo setor. Isso se deve fundamentalmente ao pronunciado afastamento relativo da parede do canyon, entreposta ao observador por vários arbustos, árvore e gramíneas.
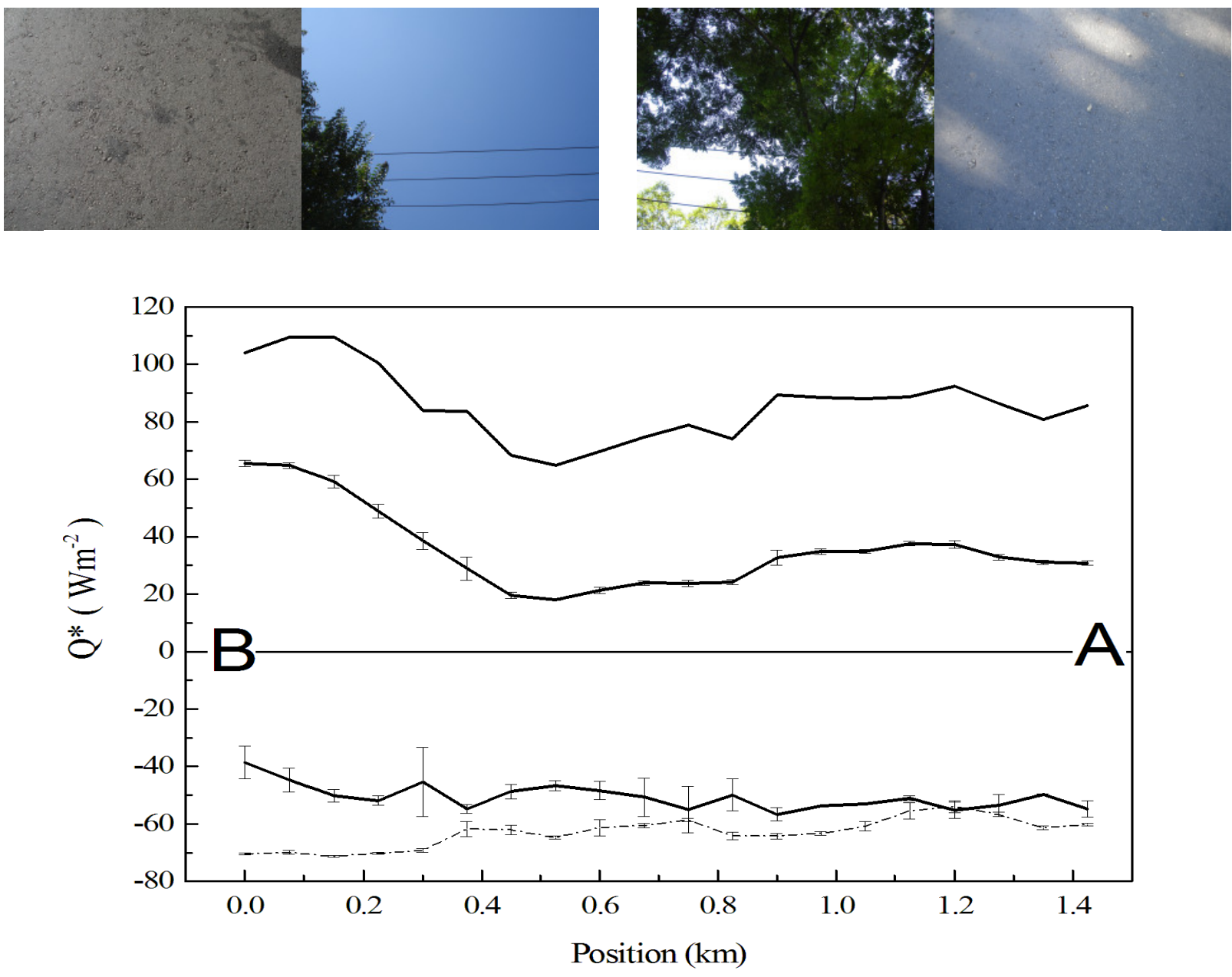

Autor: Antonio Jaschke Machado

Figura 8.16 - Distribuição espacial do balanço radiativo observado na Av. Queiroz Fo., entre os pontos B e A representados na Fig. 8.15, em torno das 8 h e 15 min de uma manhã de domingo no outono (linha contínua central), e em torno das $21 \mathrm{~h}$ e $52 \mathrm{~min}$ de uma noite de quarta-feira no inverno (linha tracejada abaixo). As linhas contínuas mais acima e mais abaixo representam, respectivamente, a componente de onda curta estimada para este balanço $\left(\mathrm{K}^{*}\right)$ e a componente de onda longa observada para este balanço ( $\left.\mathrm{L}^{*}\right)$. As imagens acima indicam cenas não simultâneas do nadir e do zênite para as posições correspondentes ao gráfico. 

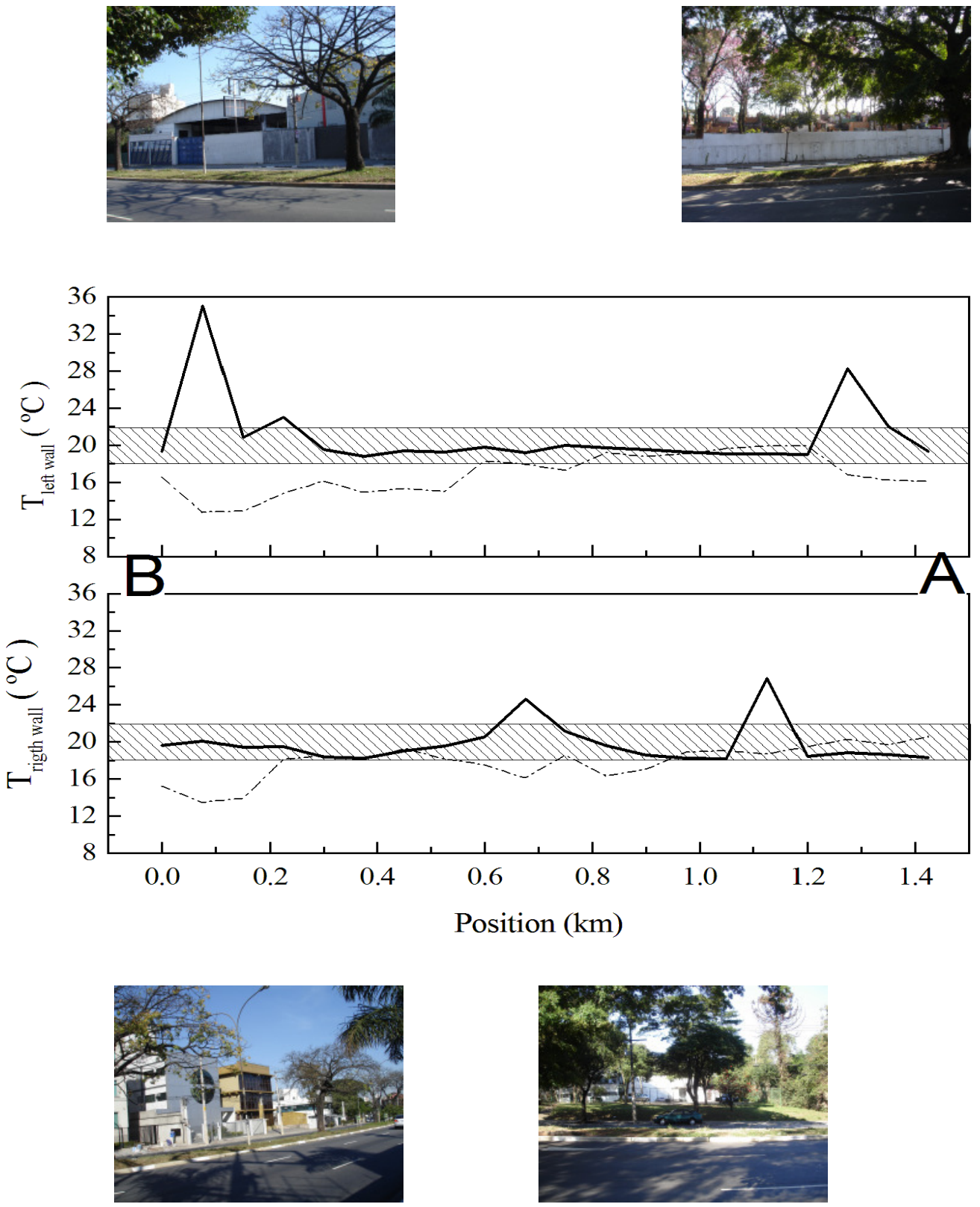

Autor: Antonio Jaschke Machado

Figura 8.17 - Distribuição espacial da temperatura das paredes observadas na Av. Queiroz Fo., entre os pontos B e A representados na Fig. 8.15, em torno das 8 h e 15 min de uma manhã de domingo no outono (linhas contínuas), e em torno das 21 h e $52 \mathrm{~min}$ de uma noite de quarta-feira no inverno (linhas tracejadas). As linhas acima representam as paredes que compõem a face sul, enquanto as linhas abaixo representam as paredes que compõem a face norte. As imagens acima e abaixo indicam, respectivamente, cenas não simultâneas da face sul e da face norte para as posições correspondentes ao gráfico. Áreas hachuradas nos gráficos indicam a amplitude da temperatura do ar observada entre as duas situações estudadas. 


\subsection{Compreensão sobre os elementos emissores urbanos}

\subsection{1. À GUISA DE CONCLUSÃO}

\subsubsection{A variabilidade dos fluxos radiativos observada em movimento}

A imagem do esquema experimental em si (Fig. 2.1) já é suficiente para indicar um aspecto indubitavelmente original e ao mesmo tempo desafiador deste processo de investigação científica.

Quando se idealizou inicialmente o experimento, tendo sempre em mente os trabalhos já desenvolvidos especialmente por Timothe Oke e seus seguidores, em particular a J. A. Voogt, o conceito da plataforma móvel se apresentava como algo já vislumbrado dentro das possibilidades experimentais em clima urbano.

Neste âmbito, as observações do fluxo radiativo em ondas longas com a utilização de um pirgeômetro acoplado à plataforma móvel já parecia ser um elemento suficiente que respaldaria todos os esforços. Porém, a partir do momento em que se concebeu a possibilidade de acoplar um saldo-radiômetro à dianteira de um veículo em movimento pela cidade - e aqui deve-se creditar méritos à genialidade e encorajamento de Tarik Rezende de Azevedo - e, posteriormente, materializando-se esta possibilidade, foi possível vislumbrar algo que pôde ir além dos próprios objetivos iniciais deste trabalho.

Agora é possível investigar algo que ultrapassa a mera observação da componente L $\downarrow$. Tornou-se possível, também, verificar o próprio cômputo geral dos fluxos radiativos $\mathrm{Q}^{*}$, em um intervalo espectral muito mais amplo; estimar $L^{*}$, com referência à superfície que 
compõe o chão propriamente dito, o piso do canyon urbano, a superfície do solo em si ou o que dele restou, ou, ainda, o que sobre ele se modelou, desde o início deste projeto um desafio preocupante; e, graças também aos procedimentos paramétricos aplicados, atingirse uma estimativa de $\mathrm{K}^{*}$ e suas componentes normais ao piso.

Estes procedimentos foram extremamente relevantes, pois houve a possibilidade de se acoplar um sensor à proa do carro, que, apesar de não dispor de observações diretas de todas as componentes, era muito mais leve e versátil, além de apresentar um custo reduzido.

A experiência de pilotar um veículo, com este sensor acoplado à frente, é reveladora sobretudo a quem pilota e tem a capacidade de simultaneamente verificar os sinais adquiridos em tempo real e automaticamente. O georeferenciamento simultâneo também se mostrou sem dúvida alguma fundamental, mas seu resultado e significado era sempre apreciado a posteriori.

Entretanto, a visualização simultânea dos fluxos radiativos observados $\left(\mathrm{Q}^{*}\right.$ e L* ao nível da plataforma), à medida que o próprio observador desloca-se pela intrincada cobertura da mancha urbana de uma grande metrópole, abre uma perspectiva enorme onde os insigths afloram toda a intuição acumulada por experiências pretéritas abrindo um horizonte de quão vasta pode ser a complexidade da distribuição dos fluxos radiativos que emergem do detalhamento abaixo das coberturas.

As flutuações entre os sinais do saldo-radiômetro e do pirgeômetro pareciam indicar algo muito além da simples limitação do tempo de resposta dos sensores. Pareciam indicar algo que não se percebe em uma plataforma fixa, sempre limitada ao efeito advectivo das características provenientes das áreas fonte no caso dos fluxos convectivos turbulentos, e ao efeito de obstrução no caso dos fluxos radiativos propriamente ditos. Pareciam indicar o próprio resultado da travessia de áreas, regiões e sub-regiões dominadas por distintos microclimas e mesoclimas, despontando nuanças sutis que de tão frágeis somente em movimento e em atitude concentrada pode-se sentir entre estas duas escalas mais vigorosas. Pareciam delinear os topoclimas, tão dificilmente estabelecidos entre os valores médios 
com grande inércia da mesoescala e a turbulência atônita da camada baixo das coberturas, mas bem definidos por variâncias e co-variâncias de padrões evidentes.

Toda a sistematização do que é analisado e investigado a seguir carrega sempre a lembrança e o feeling destes momentos ímpares que somente o observador, dentro de seu veículo e com o visor do sistema de aquisição ao lado, pode sentir, perceber, registrar em sua mente.

Temo por não ter conseguido ainda reproduzir tudo o que pude perceber em campo, foi uma experiência nova e complexa com este tipo de arranjo. Tento ser minimamente honesto quando apresento as barras de erro, informações da sensibilidade dos aparelhos e a preocupação em adquirir os valores absolutos. Mas também não posso privar-me de apresentar apaixonadamente uma cena que tanto me tocou. Acredito que há algo ainda a ser mostrado e que não tive ainda capacidade de traduzir em texto, gráficos, fotos, tabelas, equações ou modelos.

Mas de qualquer modo, esta percepção inicial, em campo, ainda longe dos computadores, constitui nossa primeira evidência da variabilidade espacial que se procura demonstrar.

\subsubsection{O efeito temporal sobre observações espaciais em movimento}

O problema da variabilidade temporal durante as observações é um fato irrefutável e o mais óbvio de todos. Para usar uma expressão tantas vezes empregada por Nélson Rodrigues, é o óbvio ululante, que de tão óbvio é o primeiro aspecto a ser investigado nas séries de dados levantadas em plataformas fixas.

Simplesmente não há como evitar a sucessão das observações em um aparato de observação constituído por um único conjunto de equipamentos. Não há como fugir de uma das realidades mais básicas de qualquer elemento físico, a sua característica temporal. E é justamente neste ponto que repousa a principal crítica a este trabalho, pelos comentários 
que tenho oportunidade de ouvir nos locais onde tenho a satisfação de apresentar aspectos dos experimentos realizados.

Por tudo o que experimentei em campo com este aparato, a mensagem que posso encaminhar nestas linhas que se aproximam do final, é que a temporalidade dos elementos, de tão fundamental que é, não pode por isso mesmo justificar o desprezo por estes experimentos e muito menos servir de argumento definitivo para a não realização destes.

Desde o início houve preocupação com isto que está exposto. Além de reconhecer o problema da calibração dos sensores, os quais foram utilizados em aquisição recente e provenientes de procedimentos de calibração em laboratórios especializados, não deixaram, porém, de ser ainda aferidos durante os procedimentos preliminares em condições especiais, e mesmo em campo, visando-se o reconhecimento de variações de amplitude do sinal que fossem características.

Há ainda que se reconhecer o problema do tempo de resposta inerente a cada equipamento. Utilizou-se, então, um intervalo de amostragem extremamente baixo, de 2 segundos. Com isto pôde-se aproveitar a grande capacidade de rápida resposta do pirgeômetro e dos sensores IRTs. Mas verifica-se a perda de significância quando se nota a maior inércia do saldo-radiômetro, em torno de 10 segundos. Por este motivo, fixou-se o intervalo de armazenamento em 10 segundos. Dessa maneira, o que se perdia de representatividade no sinal de $Q^{*}$ durante a amostragem, era preservado em seu limite durante o armazenamento dos dados que efetivamente seriam analisados. Além de elevar-se ao máximo a resolução espacial que se poderia obter, definitivamente limitada não tão em grande parte pela velocidade com que o veículo se deslocava, mas na verdade modulada por esta própria limitação do saldo-radiômetro.

Superada esta barreira restava demonstrar em si a influência da variabilidade temporal dos dados sobre o conjunto adquirido. Uma condição inicial sempre foi respeitada durante os experimentos, com exceção do EM1 e do EM11, por razões óbvias que já foram mencionadas. O local de partida deveria ser sempre o mesmo que o de chegada, permitindo uma eventual correção temporal (como no caso apresentado para o efeito de ilha de calor), sobretudo se houvesse a percepção durante o experimento de amplitude térmica elevada 
ocasionada principalmente por alguma alteração abrupta das condições meteorológicas. Isso, tendo-se em vista que alterações nestas condições podem implicar variabilidades de amplitude dos sinais bem menos tênues que aquelas associas à variabilidade da posição do disco solar (variação diurna), ou à variabilidade ocasionada pelas próprias características térmicas dos materiais devido a sua inércia térmica ou admitância térmica (sobretudo no período noturno).

Enfim, busca-se demonstrar que apesar de em movimento, pôde-se apreender algo do equilíbrio térmico que se estabelecia pelas diversas localidades da metrópole, a par das validações demonstradas tanto para o saldo-radiômetro como para o pirgeômetro.

Surge então uma segunda evidência extremamente significativa, que se observa sistematicamente, mas está bem exposta na Figura 4.3. Nota-se durante os transectos uma variabilidade de amplitude elevada, em curtos intervalos de tempo (alguns minutos), que seria apenas observada considerando-se somente a temporalidade em intervalos de tempo muito mais longos (horas), isto para não citar as amplitudes extremas verificadas.

É possível verificar amplitudes que variam desde $20 \mathrm{Wm}^{-2}$ a até $60 \mathrm{Wm}^{-2}$ considerando-se apenas a evolução do valor médio, entre diferentes localidades, com suas características inerentes. Em relação aos valores absolutos adquiridos esta variação é ainda maior, podendo chegar a até $80 \mathrm{Wm}^{-2}$. Não se mencionam aqui casos ainda extremos que não são freqüentes mas podem ainda ser significativos em localidades específicas da metrópole.

Esta variabilidade verificada na emissão térmica $L \downarrow$ não é tão proeminente como para o fluxo L $\uparrow$, mas dá indicação de como o aparato é capaz de perceber os diferentes padrões de equilíbrio térmico que vão se delineando pela metrópole. Estes padrões são menos perceptíveis para a temperatura do ar (Fig. 4.3b) mas acompanham uma evolução semelhante, mesmo sendo sensores independentes.

As barras de desvio durante o dia, para a temperatura do ar e do anel ao redor do sensor saldo-radiômetro raramente interceptam (Fig. 4.3b, linhas pontilhadas acima, ficando a segunda quase sempre abaixo). Isto indica uma contribuição significativa para o sinal de $\mathrm{Q}^{*}$ proveniente da atmosfera e das coberturas ao redor. O termopar no anel apresenta 
eventualmente desvios mais elevados associados fundamentalmente à cessação da ventilação nos episódios em que o veículo forçosamente pára, mesmo assim raramente atingindo o extremo inferior do desvio para a temperatura do ar. Toda esta discussão serve, em última análise, para corroborar o significado das travessias realizadas durante os experimentos móveis, e que compõem a base de dados.

A variabilidade temporal possui sua representatividade, tentando-se apreender os diversos ritmos a partir de uma distribuição sistemática das observações (Tabs. 4.1 e 4.2), seja através da sazonalidade, de menor significância neste estudo, seja através da insolação, devendo-se observar que sua amplitude é reduzida no interior dos canyons urbanos, verificando-se características diurnas dos fluxos sobretudo entre 9 e 17 horas, de um modo conservador para as situações de verão, seja ainda através das atividades humanas.

A representatividade espacial das diversas localidades é atingida através das diferentes geometriais que podem ser desenvolvidas durante as travessias: transetos, sempre com retorno (EM-8); polígonos fechados (EM-6); polígonos fechados que se cruzam (EM-26); ou combinações de transetos com polígonos (EM-34). Dessa maneira, áreas muito extensas e homogêneas podem ser percorridas por longos transetos; áreas muito extensas, mas de significado imprescindível podem ser percorridas por grandes polígonos; e, áreas de grande diferenciação da cobertura do solo podem ser percorridas por polígonos e transetos menores. Vale ressaltar que não apenas os extremos de um transeto podem representar a variabilidade em uma área, mas as bordas opostas dos polígonos igualmente representam nuanças desta variabilidade apreendida no conjunto de dados que é adquirido. 


\subsubsection{Distribuição espacial das emissões}

O georreferenciamento dos dados foi fundamental não apenas para localizar astronomicamente os dados, mas, sobretudo, para dar a exata medida de sua distribuição através das diferentes áreas, com suas características peculiares, que cobrem a metrópole (Fig. 5.1 e Tabs 5.1 e 5.2). Ele propiciou, em um segundo momento, uma localização com maior significado geográfico do ponto de vista de quem vive na metrópole e experimenta diversos tipos de relação entre os diferentes bairros e regiões da metrópole.

A partir do georreferenciamento fica evidente uma concentração maior dos dados na região interior do município de São Paulo, delimitada pelas vias Marginais. Nesta área a repetição de observações também foi maior. Por este setor circula a maior parcela da população metropolitana, e juntamente com esta circulação associa-se uma variabilidade mais intensa dos tipos de ocupação.

As observações na periferia também são relevantes, mas os tipos de ocupação possuem um

gradiente mais suave. É o lugar dos grandes domínios. Todavia, estas feições repetem-se em uma escala bem mais localizada no setor central, seja através das características peculiares dos materiais, seja através das formas. Desde o tipo arborizado, da Cantareira periférica aos bairros verdes centrais, até a ocupação de habitações baixas, dos grandes bairros dormitórios às favelas.

Travessias mais longas que atingiram os extremos da metrópole mostraram-se úteis também para explicitar situações com condições meteorológicas atípicas para as áreas centrais, como a ocorrência de nevoeiros e de circulações de mesoescala que ficam melhor evidenciadas nestes percursos.

De uma maneira geral, os elementos que constituem a essência das emissões parecem estar sempre presentes (Fig. 6.3 e Figs. 2.3 a 2.6). Estes elementos podem ser verificados nos diferentes modos de observação, em movimento ou fixo, mas, de qualquer modo, estão presentes em todos os setores, com distintas parcelas de participação, mas não tornando-se ícones específicos dos setores urbanos ou rurais da metrópole. Aliás, esta própria dicotomia deve ser superada em sua compreensão. Não há elementos exclusivos de um ou de outro, 
mas o que há é um gradiente muito maior dos tipos em um meio dito urbano, o que determina o seu detalhamento muito mais complexo.

Estes elementos fundamentais, árvores, asfalto, paredes e ar, os primeiros definidos pelos diferentes materiais e o último pelos seus constituintes, despontam das observações por diferentes métodos e implicam nas condições sentidas pelos indivíduos na cidade. No caso específico das emissões térmicas, as formas surgem como elemento fortemente determinante, mas não exclusivo, principalmente quando são comparadas as áreas mais abertas a estas, onde a atmosfera se sobrepõem à forma da arquitetura dos lugares. Observese o efeito de ilha de calor identificado em seu ápice próximo às Marginais.

Restringindo a discussão ainda mais pela natureza das emissões, e tendo sempre em vista as peculiaridades dos equipamentos montados nos experimentos móveis, nota-se a possibilidade de interpretar os dados não só com sua componente tipicamente vertical que aqui sempre se refere a $\mathrm{L}^{*}$. Mas há também uma possibilidade de entender este balanço em ondas longas como também possuindo uma componente horizontal (Fig. 6.7).

Pelo que se demonstra (Capítulo 2.3, item 2), o resultado da influência da emissão térmica sobre o indivíduo, de uma maneira geral, não depende apenas deste balanço vertical mas também da influência horizontal pelas paredes e obstáculos verticais. Ainda mais percebendo-se que o deslocamento dos indivíduos ocorre sempre à margem das vias públicas, sobre os calçamentos. Imaginando-se uma situação hipotética, onde deixe de se considerar o papel virtual de algumas coberturas significativas, como os setores arborizados, obtém-se um fluxo resultante em ondas longas que não é exatamente vertical, a partir do piso, mas é de algum modo oblíquo com um viés em torno de $15^{\circ}$ em média e traz consigo a parcela relevante das paredes. Por este motivo, é tão emblemática a representação da emissividade superficial não apenas pela cobertura asfáltica das ruas, mas também pela contribuição genérica das paredes (Tab.6.1).

Os experimentos fixos tornam-se, então, extremamente relevantes nesta compreensão, pois podem de alguma maneira servir como agente aferidor do que se observa em movimento. 
Observe o resultado na Figura 6.8. A temperatura do asfalto possui uma distribuição de máximo bem definido, enquanto as paredes parecem indicar uma situação bi-modal. De um modo geral as paredes obviamente estão inexoravelmente atreladas ao seu posicionamento fixo e é simplesmente isto que se interpreta deste resultado.

Mas quando se comparam os valores mais freqüentes, nota-se um valor típico de $22,5^{\circ} \mathrm{C}$ para o asfalto. Enquanto para as paredes os máximos ficam em torno de de $15^{\circ} \mathrm{C}$ e $20^{\circ} \mathrm{C}$ para o nível inferior e em torno de $24{ }^{\circ} \mathrm{C}$ para o nível superior. Para o nível superior percebe-se que as paredes mais aquecidas possuem uma freqüência maior, 300 ocorrências contra apenas 250 , em relação ao valor típico encontrado para o asfalto. Mas, as paredes poderiam, portanto, apresentar uma contribuição mais significativa ao fluxo resultante em ondas longas, que aquele representado pelo desvio angular de apenas $15^{\circ}$. Realmente, em um canyon urbano os efeitos entre as paredes tendem muito mais a se equilibrarem do que na direção vertical.

Porém, há algo importante e fundamental aqui. Não importa tanto que um elemento esteja mais aquecido do que outro. Importa sim, em grande parte, o quanto suas propriedades radiométricas são relevantes.

Em termos das ondas longas, a emissividade é fundamental, ou seja, a capacidade que o material constituidor dos corpos possui em emitir radiação térmica.

Assim, como nunca se trabalha na realidade com corpos negros perfeitos, têm-se aqui corpos cinzas que, através da lei de Stefan-Boltzmann, contribuem com suas parcelas emitivas, modulas sobretudo pelas emissões estimadas na Tabela 6.1.

Apesar do asfalto apresentar a capacidade, em média, de emitir mais do que as paredes, mesmo com temperaturas ligeiramente inferiores, há um desvio significativo a ser observado.

Com uma emissão relativamente baixa em média, em torno de 0,84 , as paredes apresentam também um erro relativo maior de $7 \%$, que pode acarretar um máximo possível de 0,9 . Esta variabilidade emissiva é fruto da grande diversidade de materiais que compõem as paredes. 
Há outras características muito interessantes da natureza física-emitiva dos elementos analisados (Fig. 6.4). Destaca-se os episódios em que a cobertura vegetal torna-se mais aquecida abaixo da copa do que acima (Fig. 6.4 b). Ou os episódios em que a temperatura do ar exposto torna-se mais baixa do que o ar confinado a uma área sombreada (Fig. 6.4 b). Ou ainda o valor mínimo acentuado da temperatura do ar (em torno do instante 500 na Fig. $6.4 a)$.

Isto é resultado de um padrão complexo da vegetação, associado aos processos termoreguladores da estrutura foliar, que tende a cessar a elevação da temperatura mesmo mediante à incidência solar através das movimentações estomatais.

Outro episódio é o efeito das brisas de natureza intra-urbana que nitidamente são percebidas pelo observador (Capítulo 2.2, item 2, EFX-2); ou ainda o efeito evaporativo do orvalho sobre uma superfície, que tende a diminuir a temperatura de uma superfície por perda de calor latente, e, consequientemente, do ar adjacente a ela em um segundo momento (Capítulo 2.2, item 2, EFX-3).

Enfim, com base em todos estes aspectos surge a terceira evidência significativa deste trabalho. O fluxo L* resultante, característico, sob diversas situações e horários, para a metrópole gira em torno de $75 \mathrm{Wm}^{-2}$ e é negativo. Respaldado por uma freqüência em torno de 4.000 valores. A magnitude deste valor pode ser em certa medida contestada de um modo mais amplo. Sendo melhor talvez definir um intervalo entre $50 \mathrm{Wm}^{-2}$ e $100 \mathrm{Wm}^{-2}$, com mais de 15.000 observações sistemáticas.

De todos os modos, porém, algo parece ser incontestável, com maior ou menor magnitude o fluxo $\mathrm{L}^{*}$ na metrópole é caracteristicamente negativo. Indicando que em uma região como esta, apesar ainda da idéia dos canyons urbanos ou da atmosfera poluída que tendem a diminuir a perda radiativa por ondas longas, há uma clara tendência geral em se perder energia pelos processos radiativos de natureza termo-emissiva. 


\subsubsection{Localização das emissões térmicas}

É preciso distribuir para localizar. Localizar em um sentido muito mais amplo, não apenas no sentido restrito da localização em coordenadas astronômicas. Localizar em termos dos ritmos, em termos dos logadouros e lugares significativos para a população que habita a metrópole, e também em termos das relações com os poluentes e constituintes da atmosfera urbana.

Quando se distribuem os dados adquiridos pelo domínio da região metropolitana, curiosamente observa-se um padrão menos consistente do fluxo $\mathrm{L}^{*}$ do que em termos do seu parâmetro derivado e definido como sua divergência vertical $-\nabla_{h} \cdot L^{*}$.

Apesar de em módulo esta componente da divergência ser idêntica ao próprio gradiente vertical, ela traz em si o significado da natureza radiante do elemento estudado. Ou seja, não simplesmente posto como um fluxo retilíneo, mas como um fluxo tridimensional, esférico e isotrópico.

Além disso, de um modo simplificado, a divergência representa ou está associada à idéia de um gradiente térmico vertical, graças à possibilidade de ser caracterizada por distintos valores da emissão térmica que puderam ser estimados pelo posicionamento dos radiômetros em níveis distintos.

De certa maneira, era de se esperar que em uma escala mais ampla, meso, ainda restasse algum elemento característico de uma possível variabilidade vertical. Menos contundente na escala reduzida do lugar, topo, onde definitivamente a variabilidade horizontal ganha relevância em termos dos diversos tipos de ocupação.

Todavia, é surpreendente a princípio como a divergência derivada dos dados observados parece se adequar muito bem em especial ao ritmo semanal (Fig. 7.8b).

Isto traz um significado muito rico e parece constituir a quarta evidência relevante a este estudo. 
Como o ritmo semanal é por excelência a representação da atividade humana, tem-se aqui, talvez, a identificação do modo pelo qual esta atividade se relaciona com o seu meio atmosférico. A atividade humana, através da liberação da energia antropogênica verificada principalmente pelo ritmo ou através da modificação antrópica da superfície pela distribuição espacial, age sobretudo instabilizando o ar na camada mais inferior da atmosfera, e cujas implicações foram exploradas no Capítulo 3.1.

Portanto, pela análise do ritmo tem-se uma idéia da amplitude da energia antropogênica que pode contribuir ao balanço energético, e conforme a Figura $7.8 \mathrm{~b}$ este termo fica em torno de $20 \mathrm{Wm}^{-2}$, e negativo, o que indica liberação a partir da superfície.

Compreendido isto, pode-se então avaliar a distribuição obtida para os termos do balanço radiativo, a qual foi adquirida através dos quatro padrões principais de ocupação do solo na metrópole (Tab. 8.1).

Em termos de $\mathrm{Q}^{*}$, os bairros verdes parecem funcionar como os principais absorvedores dos fluxos radiativos naturais, ou seja, solar, na metrópole. Acumulando cerca de $100 \mathrm{Wm}^{-2}$, da qual é, provavelmente, em grande parte descontada a parcela utilizada, sobretudo pelos processos fotossintéticos, advectado o restante pelas brisas intraurbanas para os outros setores da metrópole.

A componente natural implícita em $\mathrm{Q}^{*}$ parece ser melhor explicitada quando observada a distribuição de $K^{*}$, com padrões muito semelhantes. À exceção das ocupações industrial e residencial, onde claramente verifica-se um fluxo de $\mathrm{K}^{*}$ significativamente mais intenso para o setor industrial, com uma discrepância da ordem de $50 \mathrm{Wm}^{-2}$.

Esta discrepância é oriunda do terceiro termo, o fluxo L*. Portanto, surge aqui uma evidência, a quinta, também significativa, o setor industrial funciona como um emissor de energia antropogênica da ordem de $50 \mathrm{Wm}^{-2}$, em ondas longas. Como este setor é dominado em grande parte por vias de transporte expressas, e considerando-se o contundente declínio da própria atividade industrial neste setor durante as últimas décadas, esta parcela parece estar intimamente vinculada ao calor liberado pelo fluxo de veículos. 
Note-se que esta quantidade de energia liberada é da mesma ordem de grandeza que a contribuição de natureza geométrica, definida pelo tipo verticalizado característico de uma ocupação por canyons urbanos, e representada por uma perda, reduzida, também em torno de $50 \mathrm{Wm}^{-2}$.

E finalmente, deve-se mencionar o resultado idêntico obtido em L* comparando-se os tipos verde e industrial. No caso dos bairros verdes, como estes são os principais absorvedores da energia solar, e considerando-se a vegetação como um emissor caracteristicamente próximo ao modelo de corpo negro, seria mesmo de se esperar que estes setores da metrópole funcionassem também como eficientes emissores.

Buscando concluir esta reflexão agora em termos do balanço de energia, deve-se frisar o papel deste estudo na identificação dos termos fonte deste balanço. A contribuição dos saldos radiativos e do termo antropogênico.

Neste caminho, observa-se a importância do estudo da distribuição espacial dos fluxos em ondas longas, não por apenas compreender a distribuição de $\mathrm{L}^{*}$, mas também por reconhecer a sua importância como identificador das atividades antrópicas.

Assim, tendo-se sempre em vista a distribuição de Q* (Tab. 8.1) e a estimativa obtida para a amplitude do ritmo semanal em torno de $20 \mathrm{Wm}^{-2}\left(\mathrm{Q}_{\mathrm{F}}\right)$, pode-se dizer que: todos os tipos de ocupação possuem uma fonte energética seja $\mathrm{Q}^{*}$ ou seja $\mathrm{Q}_{\mathrm{F}}$; o único caso em que $\mathrm{Q}_{\mathrm{F}}$ aparece como única fonte e $\mathrm{Q}^{*}$ é um sumidouro de energia é o do setor verticalizado, em todos os outros setores a fonte principal ainda é Q*; o bairro verde é o setor onde há maior disponibilidade de energia, $\mathrm{Q}^{*}+\mathrm{Q}_{\mathrm{F}}$, e constitui-se, portanto, no principal setor onde os fluxos turbulentos agirão dissipando a energia da metrópole para a atmosfera. 


\subsubsection{CONSIDERAÇÕES FINAIS}

O método de trabalho aplicado permite alguns avanços no estado da arte em climatologia urbana. A valorização das medições móveis permite identificar um padrão radiométrico abaixo das coberturas, naquilo que se convenciona definir como Urban Canopy Layer (UCL) nada homogêneo.

Quando se define o fluxo radiativo como característico de uma localidade, em geral raciocina-se em relação a uma camada de ar acima do UCL. Medições móveis no interior desta camada, mais próxima ao chão, indicam tanto uma real heterogeneidade espacial da magnitude do fluxo radiativo e, conseqüentemente, uma distribuição associada, bem como a revalorização dos estudos radiométricos ao perceber-se que esta distribuição é associada a tipos de ocupação, e, portanto, associada aos possíveis topoclimas existentes em uma área de estudo.

Os padrões identificados apenas surgem como resultado da aplicação exaustiva do método móvel de observação. É muito pouco provável, e certamente muito mais custoso em diversos aspectos, que tais padrões possam ser assimilados em uma rede fixa. As nuanças associadas à variabilidade topoclimática são sensíveis apenas ao observador móvel, sobretudo no caso dos fluxos radiativos. Até mesmo no caso dos fluxos turbulentos, um observador fixo não tem garantias da abrangência espacial de suas medições, que são influenciadas e fortemente determinas pelas características advectivas. No caso dos fluxos radiativos nem ao menos esta possibilidade existe.

As observações móveis no interior da UCL são mais realistas e podem ainda aprimorar as observações em plataformas orbitais. $\mathrm{O}$ acoplamento original do saldo-radiômetro associado ao uso lateral dos IRTs indica que as correções não são apenas de caráter geométrico. Como se nota, a distribuição é mais complexa.

A propósito do acoplamento e utilização original do saldo-radiômetro, este merece especial destaque. Não se trata apenas de uma aplicação bizarra de um aparelho não menos bizarro para muitos. Mas este modo de uso possibilita dois avanços. Primeiramente, quando associado a um pirgeômetro, possibilita uma estimativa completa dos fluxos radiativos 
verticais em ondas longas, incluindo-se o saldo $\mathrm{L}^{*}$ e também a componente emitida pelo asfalto. Em segundo lugar, quando associado a um datalogger que permite visualização em tempo real dos valores amostrados, constitui-se em uma oportunidade ímpar a um observador móvel, em, por assim dizer, efetivamente sentir a variabilidade radiativa relacionada a todas as outras sensações climáticas que possam suceder desta.

Acredita-se que muito ainda pode ser feito no sentido de melhorar as condições de observação e aprimorar o aprofundamento da análise, pois novos sensores podem ser agregados. Um exemplo evidente é o sensor de umidade, que dentre outros aspectos pode trazer um novo insumo para a discussão dos padrões térmicos observados e do papel da água na superfície urbana como agente emissivo, principalmente no caso das cidades tropicais do planeta. Este aspecto permitiria compreender melhor a distribuição espacial da própria razão de Bowen na cidade. E apesar de ser ainda pouco provável a utilização de sensores turbulentos em uma plataforma móvel, pode abrir caminho para uma compreensão mais clara do particionamento energético entre as componentes turbulentas na cidade, seja sensível, seja latente.

Observações detalhadas da distribuição radiativa também contribuirão certamente para a validação de modelos numéricos e até mesmo modelos escalares das áreas metropolitanas. As observações móveis podem, inclusive, ser implementadas com aparatos de aquisição automática das coordenadas, transmissão automática dos dados amostrados para bases computacionais móveis e até mesmo visualização gráfica instantânea com o emprego de uma linguagem de aquisição mais sofisticada.

É importante destacar que quando se fala em observação móvel, significa uma observação móvel com amostragem automatizada. Não se trata de uma amostragem pseudomóvel, na qual o indivíduo desloca-se entre medições sucessivas sem ter idéia precisa do que ocorreu entre os instantes que se seguiram.

No entanto, uma coisa não deve mudar, e seria mesmo prudente que não mudasse: a relação íntima entre observador e observado. A observação móvel é por excelência uma atividade solitária, e por ser solitária permite um aprofundamento reflexivo e sensorial de limites ainda não compreendidos. A autonomia do indivíduo em campo é fundamental. A 
valoração da observação móvel deve atingir níveis elevados nas próximas décadas. Os resultados prometem ser muito mais promissores do que se apregoa até agora.

Finalizo com um fato que observei certa vez em um parque da cidade, durante minhas andanças: uma mãe, acompanhada de dois filhos pequenos, aparentando idades muito próximas, tentava dar conta do pequeno que sentado chorava insistentemente por uma folha que o outro houvera encontrado e carregava orgulhosamente consigo. A mãe sabiamente, e pacientemente, dizia ao pobre com lágrimas nos olhos: - Filho querido, o que estais fazendo aí parado? Pois lhe digo, apenas é possível encontrar outra folha se caminhares!

Pois então, saiam de suas estações fixas e caminhem... 


\section{Anexo 1. Formulário}

$\alpha=\mathrm{K} \uparrow / \mathrm{K} \downarrow$

$\alpha=\left(\mathrm{K} \downarrow+\mathrm{L} \downarrow-\mathrm{L} \uparrow-\mathrm{Q}^{*}\right) / \mathrm{K} \downarrow$

$\mathrm{L} \downarrow=\varepsilon_{\text {ceu }} \sigma \mathrm{T}_{\text {ceu }}^{4}$

$\varepsilon_{\text {claro }}=1-(1+\mathrm{w}) \exp [-(1,2+3,0 \mathrm{w})]^{0,5}$

$\mathrm{w}=46,5 \mathrm{e}_{\mathrm{a}}\left(\mathrm{T}_{\mathrm{a}}\right)^{-1}$

$\mathrm{K} \downarrow_{\text {claro }}=\mathrm{I}_{\mathrm{ex}} \cos (\mathrm{Z}) \tau_{\mathrm{r}} \tau_{\mathrm{pg}} \tau_{\mathrm{w}} \tau_{\mathrm{aer}}$

$\mathrm{F}_{\text {cld }}=1-\mathrm{K} \downarrow / \mathrm{K} \downarrow_{\text {claro }}$

$\mathrm{CI}=\mathrm{K} \downarrow / \mathrm{I}_{\mathrm{ex}}$

$\varepsilon_{\text {ceu }}=\varepsilon_{\text {claro }}+\left(1-\varepsilon_{\text {claro }}\right) \mathrm{F}_{\text {cld }}^{2}$

$\mathrm{L} \uparrow=\varepsilon_{\mathrm{o}} \sigma \mathrm{T}_{\mathrm{o}}{ }^{4}+\left(1-\varepsilon_{\mathrm{o}}\right) \mathrm{L} \downarrow$

$\varepsilon_{\mathrm{o}} \sigma \mathrm{T}_{\mathrm{o}}^{4} \approx \varepsilon_{\mathrm{o}} \sigma \mathrm{T}_{\mathrm{a}}^{4}+4 \varepsilon_{\mathrm{o}} \sigma \mathrm{T}_{\mathrm{a}}{ }^{3}\left(\mathrm{~T}_{\mathrm{o}}-\mathrm{T}_{\mathrm{a}}\right)$

$4 \varepsilon_{0} \sigma \mathrm{T}_{\mathrm{a}}^{3}\left(\mathrm{~T}_{\mathrm{o}}-\mathrm{T}_{\mathrm{a}}\right)=\mathrm{cK} \downarrow\left(1-\alpha_{\mathrm{o}}\right)$

$\mathrm{L} \uparrow=\varepsilon_{\mathrm{o}} \sigma \mathrm{T}_{\mathrm{a}}^{4}+0,08 \mathrm{~K} \downarrow\left(1-\alpha_{\mathrm{o}}\right)+\left(1-\varepsilon_{\mathrm{o}}\right) \mathrm{L} \downarrow$

$\mathrm{Q}^{*}+\mathrm{QF}=\mathrm{QH}+\mathrm{QE}+\Delta \mathrm{QS}+\Delta \mathrm{QA}$

$\mathrm{Q}^{*}=\mathrm{K} \downarrow-\mathrm{K} \uparrow+\mathrm{L} \downarrow-\mathrm{L} \uparrow$

$\mathrm{G}^{\mathrm{D}}=\sum \mathrm{a}_{\mathrm{i}} \mathrm{G}_{\mathrm{i}}$

$\mathrm{L}^{*}=\mathrm{L} \downarrow-\mathrm{L} \uparrow$ 


$$
\begin{aligned}
& \mathrm{Q}^{*}=\mathrm{L}^{*} \\
& \mathrm{~L} \uparrow=\mathrm{L} \downarrow-\mathrm{Q}^{*} \\
& \mathrm{~K}^{*}=\mathrm{K} \downarrow-\mathrm{K} \uparrow \\
& \mathrm{K} \uparrow=\alpha_{0} \mathrm{~K} \downarrow \\
& \mathrm{K}^{*}=\mathrm{K} \downarrow\left(1-\alpha_{\mathrm{o}}\right) \\
& \mathrm{L} \uparrow=\varepsilon_{\mathrm{o}} \sigma \mathrm{T}_{\mathrm{a}}^{4}+0,08 \mathrm{~K}^{*}+\left(1-\varepsilon_{\mathrm{o}}\right) \mathrm{L} \downarrow \\
& \mathrm{Q}^{*}=\mathrm{K}^{*}+\mathrm{L}^{*} \\
& \mathrm{~L} \uparrow=1,087 \varepsilon_{\mathrm{o}} \sigma \mathrm{T}_{\mathrm{a}}^{4}+0,087 \mathrm{Q}^{*}+\left(1-1,087 \varepsilon_{\mathrm{o}}\right) \mathrm{L} \downarrow \\
& Q^{*}+Q_{F}=Q_{H}+Q_{E}+\Delta Q_{S}+\Delta Q_{A}+S \\
& Q^{*}{ }_{H B}+Q_{M}=Q_{H}+Q_{E}+Q_{G}+\Delta Q_{S} \\
& Q^{*}{ }_{H B}=(K \downarrow-K \uparrow)+(L \downarrow-L \uparrow) \\
& C(t)=C_{0}+\left(t-t_{0}\right) \cdot \frac{\partial C}{\partial t} \\
& \mathrm{Q}^{*}=(\mathrm{K} \downarrow-\mathrm{K} \uparrow)+(\mathrm{L} \downarrow-\mathrm{L} \uparrow) \\
& -\nabla_{h} \cdot L^{*}(\theta, \lambda)=-\frac{\partial L *(\theta, \lambda)}{\partial z} \cong L \uparrow_{E L}(\theta, \lambda)-L \uparrow_{K Z}(\theta, \lambda) \\
& \mathrm{L}_{\mathrm{a}} \downarrow=\varepsilon_{\mathrm{a}} \sigma \mathrm{T}_{\text {ceu }}^{4} \\
& \varepsilon_{\mathrm{a}}=\varepsilon_{\text {claro }}+\varepsilon_{\text {nuvem }} \\
& \mathrm{e}_{\mathrm{a}}=10^{-2} \mathrm{e}_{\mathrm{sa}} \mathrm{UR}_{\mathrm{a}}
\end{aligned}
$$


$\mathrm{e}_{\mathrm{sa}}=6,1078 \exp \left[7,5 \mathrm{~T}_{\mathrm{a}} /\left(237,3+\mathrm{T}_{\mathrm{a}}\right)\right]$

$L \downarrow_{\zeta}=\frac{\sigma T^{4}}{\pi}\left[\alpha+\beta \ln \left(\frac{u}{\cos \zeta}\right)\right]$

$T_{i}=T_{a p}-\frac{0.25}{P} \cdot\left[\left(. T_{a p}-H\right)^{2}-K\right]$ 


\section{Anexo 2. Fichas dos experimentos}

\begin{tabular}{|l|l|}
\hline EM-1 27/07/2006 Súmula Meteorológica: sol com muitos cirrus e \\
Observações
\end{tabular}

\begin{tabular}{|ll|}
\hline EM-2 04/08/2006 & Súmula Meteorológica: ensolarado, pós frontal. \\
Observações & \\
Início: $09 \mathrm{~h} 25 \mathrm{~m}$ & \\
Fim: $11 \mathrm{~h} 00 \mathrm{~m}$ & Percurso: Dardanelos, Av. Diógenes Ribeiro de \\
& Lima, Pio XI, Tito, Desembargador do Vale, \\
& Apinagés, Gastão Mesquita, Apiacás, Piracuama, \\
& Iperoig, PARADA_01(Pai-Mãe), João Ramalho, Av. \\
& Sumaré, Turiassu, Av. Pompéia, \\
& PARADA_02(Vaga-Lume), Coriolano, Pio XI, \\
& retorno feira,Pio XI, Diógenes, Dardanelos. \\
\hline
\end{tabular}




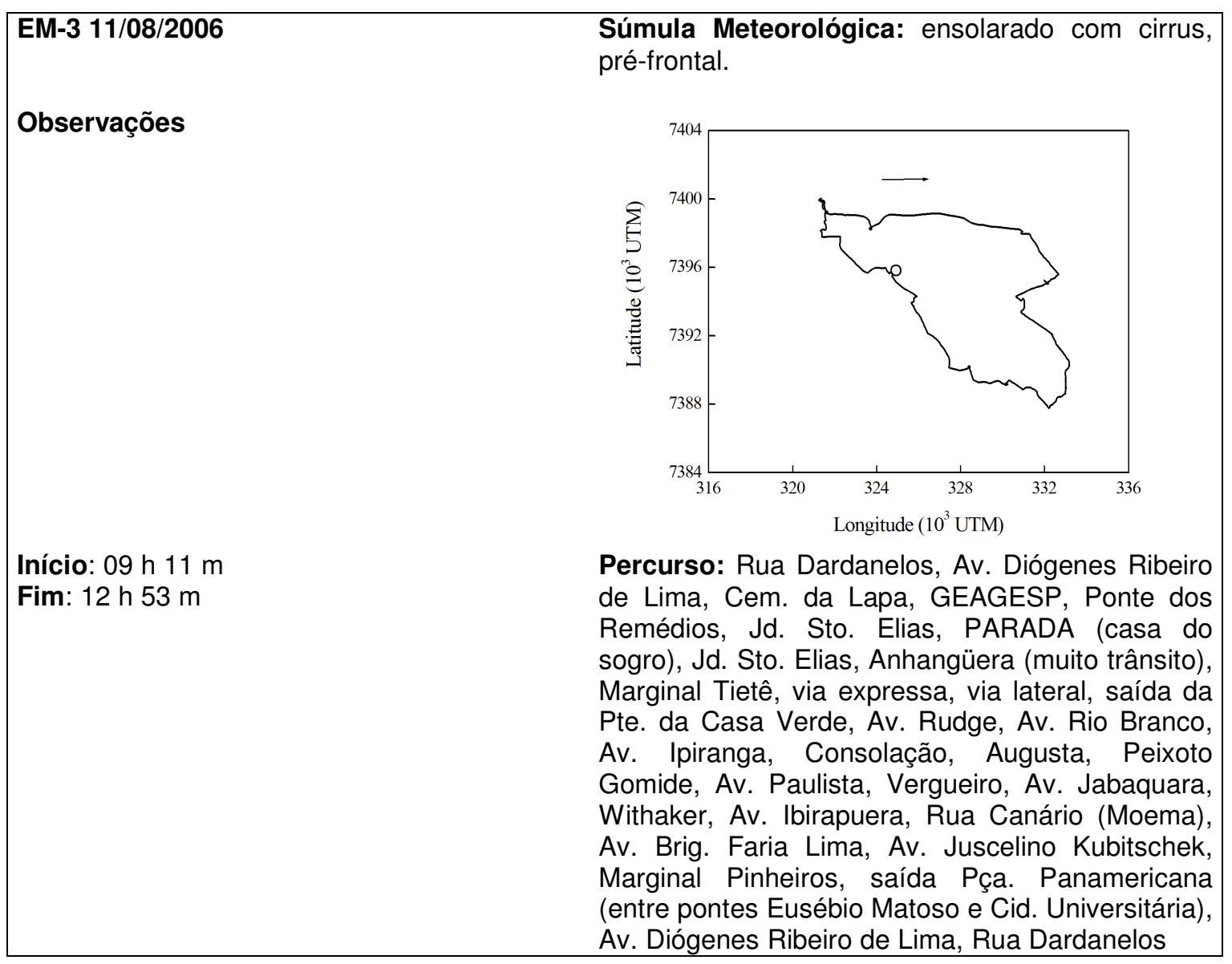




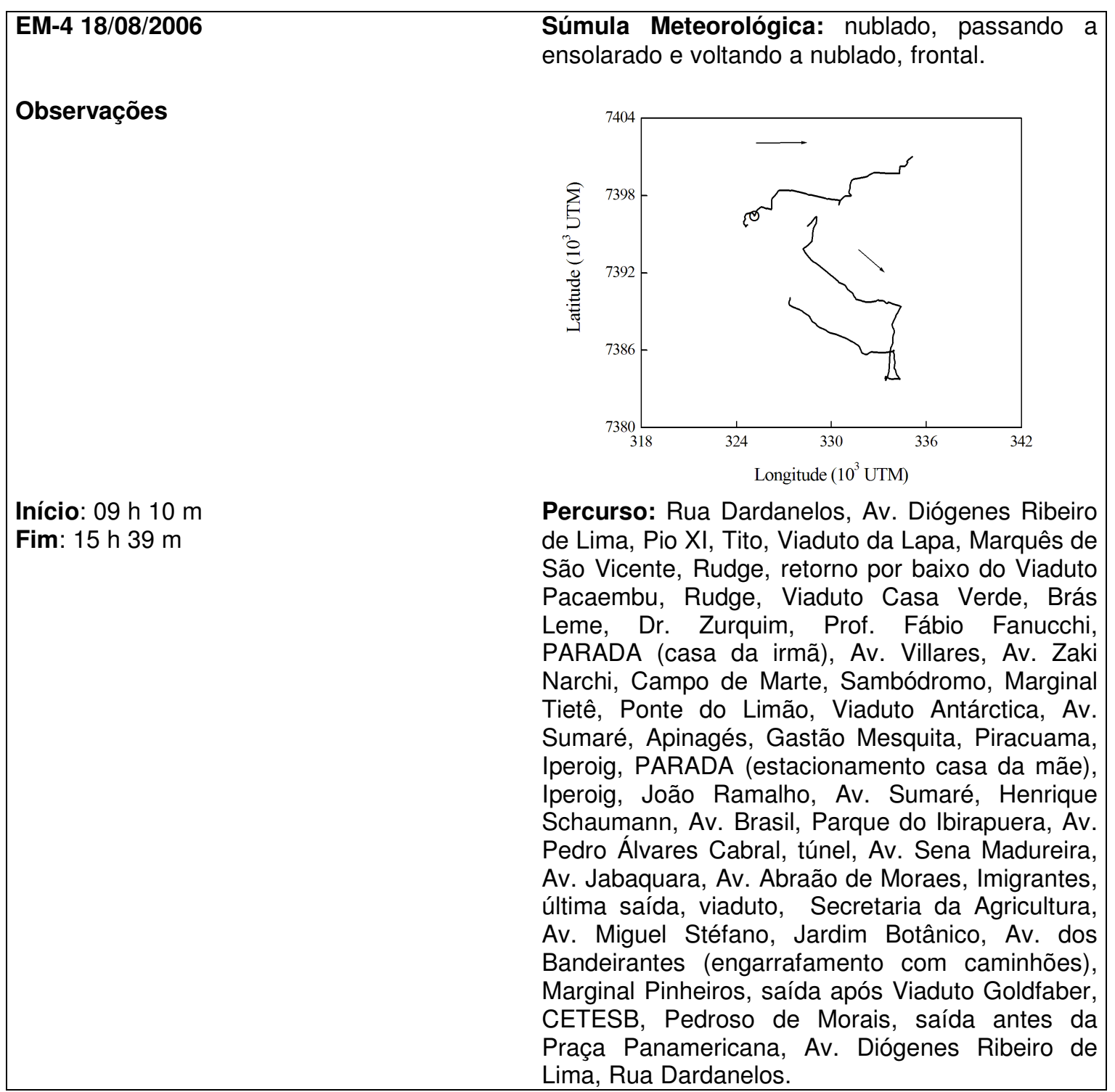




\begin{tabular}{|l}
\hline EM-5 25/08/2006 \\
Observações \\
Este circuito é muito semelhante ao padrão \\
suburbano ("suburban land cover"), muito \\
analisado por Tim Oke e seus seguidores.
\end{tabular}




\section{Observações}

(1) Trânsito lento e com muitos caminhões entre as pontes do Limão e Casa Verde, da Marginal Tietê.

(2) Testes realizados posteriormente, no dia 13.09, indicam que o par2 foi conectado na posição inversa. Por isso a temperatura diminui ao invés de aumentar. Os testes indicaram também, que quando submetido à variação brusca, o sinal é perdido por cerca de três minutos, mas retorna a seguir. Importante! Verificou-se que a conexão correta para o par2 é a seguinte: Olhando-se para as fendas dos conectores, deve-se conectar o par2 com a letra $E$ voltada para o observador.

(3) Testes realizados posteriormente, no dia 13.09, indicam que a diferença entre os sensores de temperatura fica dentro da margem de erro para estes sensores.

(4) Neste experimento foi utilizada a temperatura do ar como referência para os termopares e sensores de infravermelho.

Início: 17 h $10 \mathrm{~m}$

Fim: 19 h 22 m

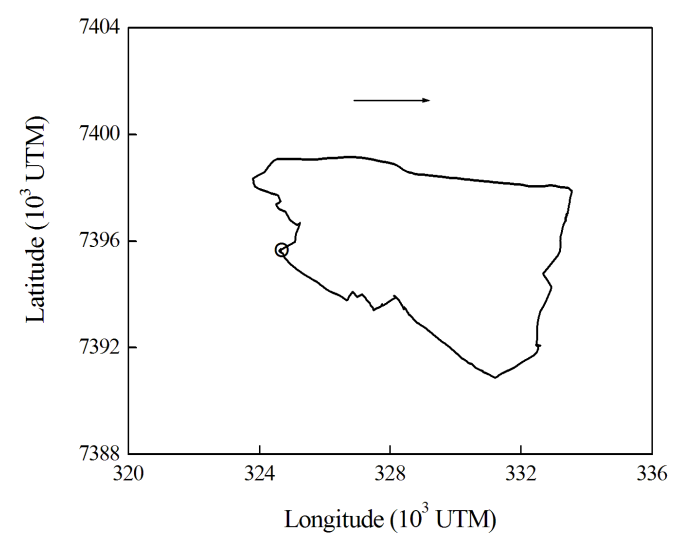

Percurso: Rua Dardanelos, Pio XI, City Lapa, saída da Anhangüera para a Marginal Tietê, saída da Ponte das Bandeiras, Av. Santos Dumont, Parque da Luz, Av. Tiradentes, Av. 23 de Maio, Vale do Anhangabaú, zona Sul, Av. Pedro Álvares Cabral, Parque do Ibirapuera, Av. Brasil, Av. Henrique Schaumann, Vila Madalena, Ignácio Pereira da Rocha, Mourato Coelho, Purpurina, Natingüi, Diógenes e Dardanelos. 


\begin{tabular}{|l|l|l|}
\hline EM-7 20/12/2006 & $\begin{array}{l}\text { Súmula Meteorológica: amanhecer ensolarado } \\
\text { sem nuvens, passando a ensolarado com algumas } \\
\text { nuvens (cirrus e cumulus) na etapa final do } \\
\text { percurso, situação pré-frontal, choveu na noite } \\
\text { anterior (pré-frontal), choveu na tarde posterior } \\
\text { (frente). }\end{array}$ \\
Observações & \\
(1) Tráfego intenso de caminhões, tanto na \\
Marginal Tietê como na Fernão Dias (ida e \\
volta).
\end{tabular}




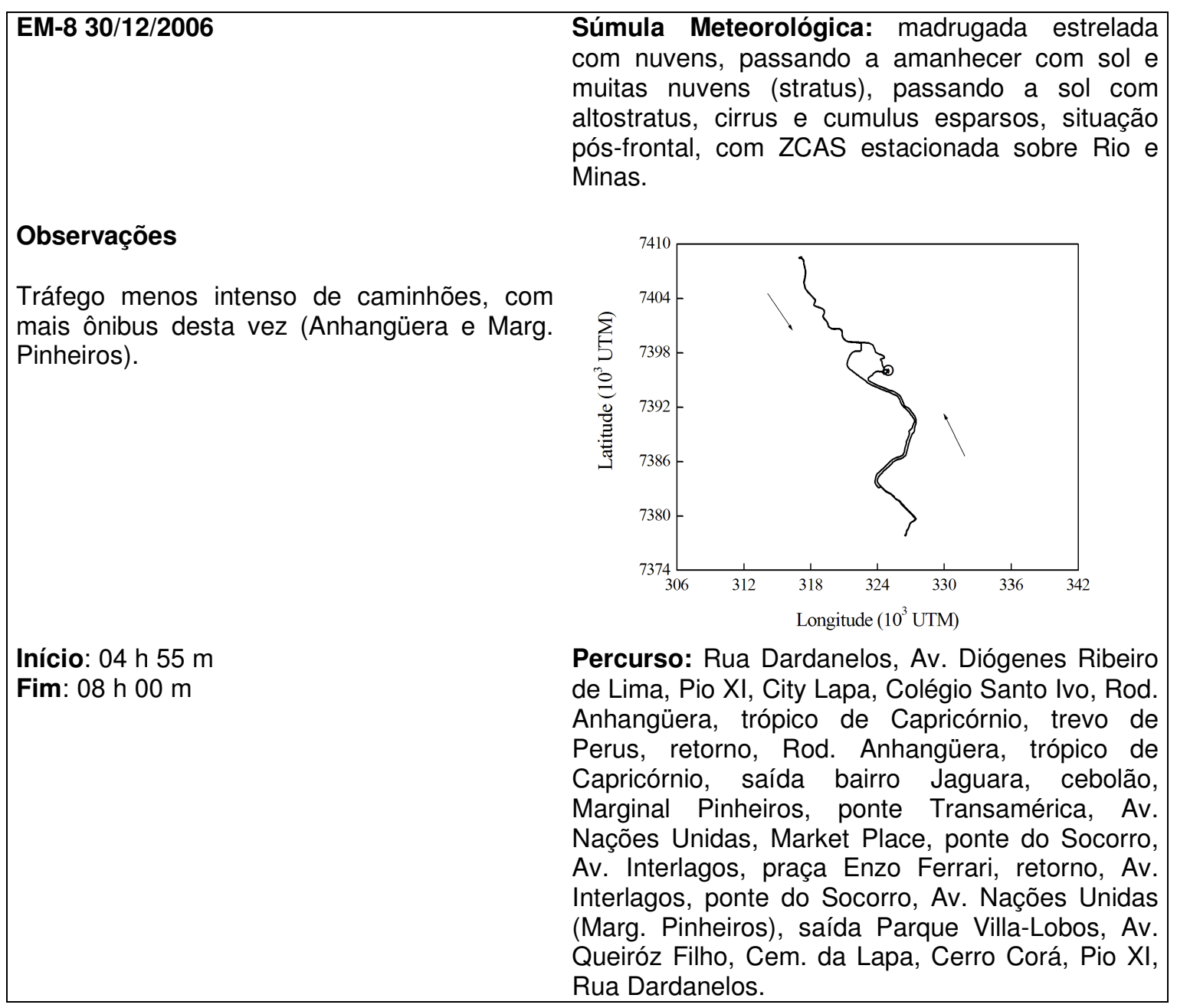




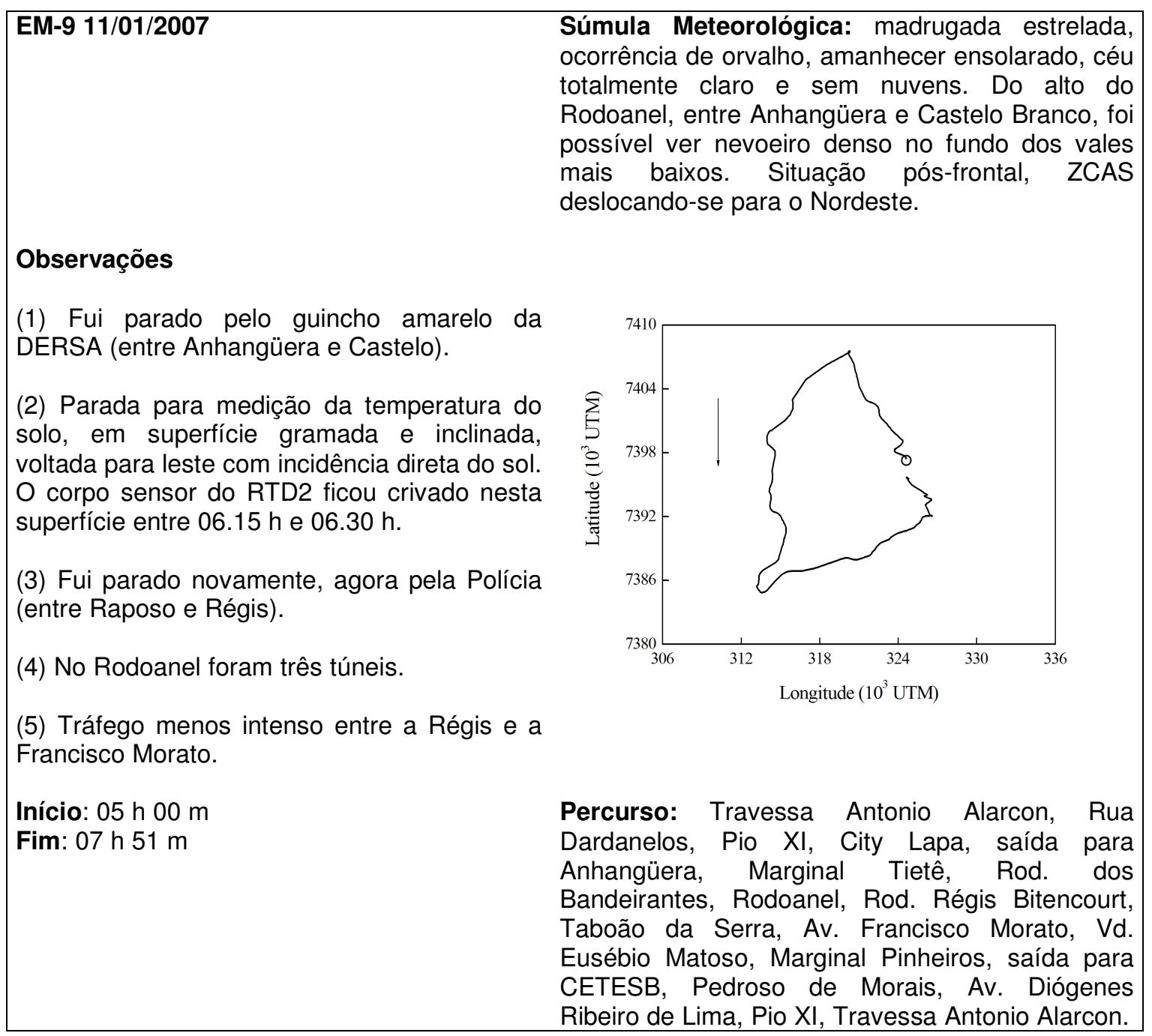




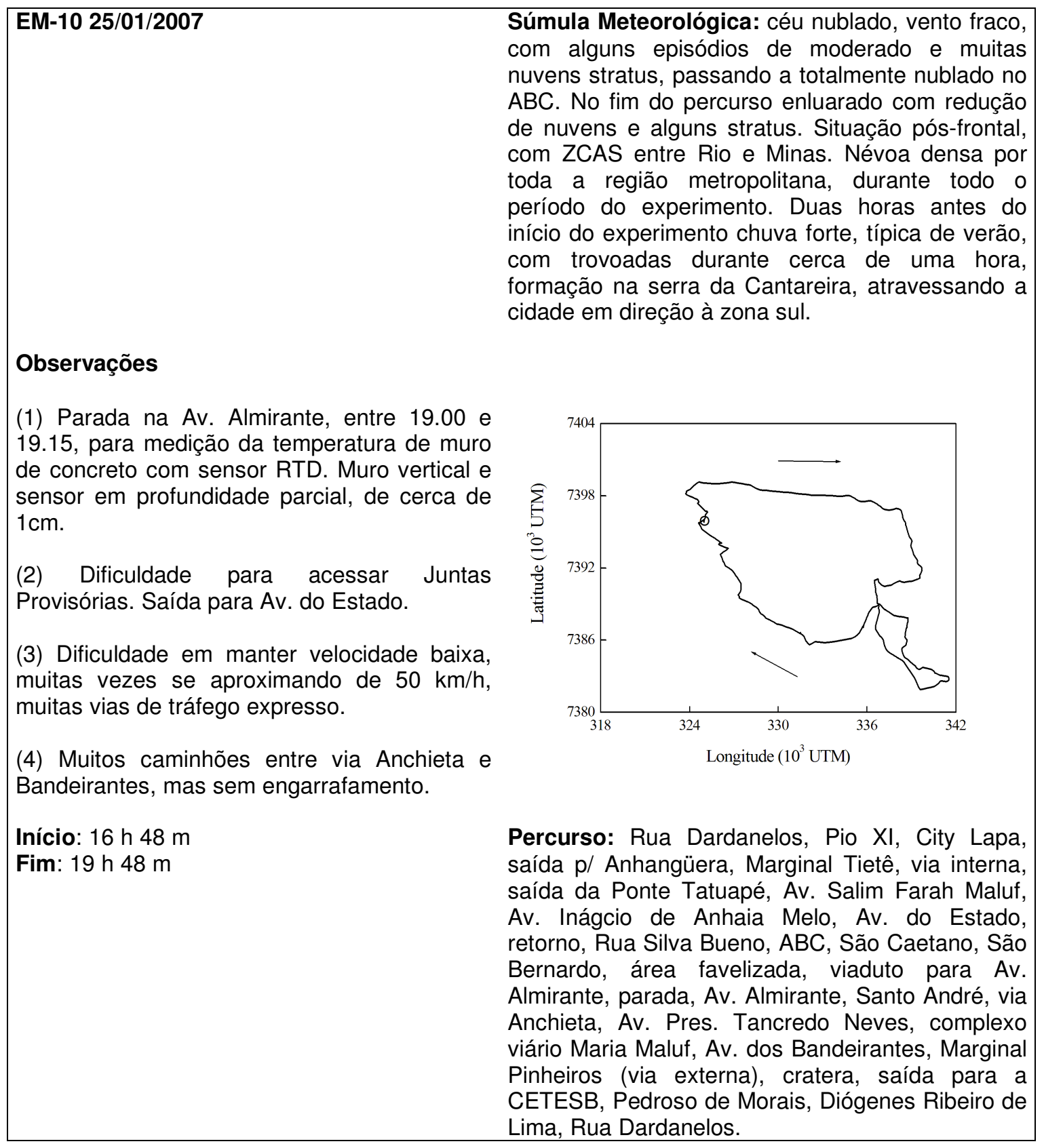




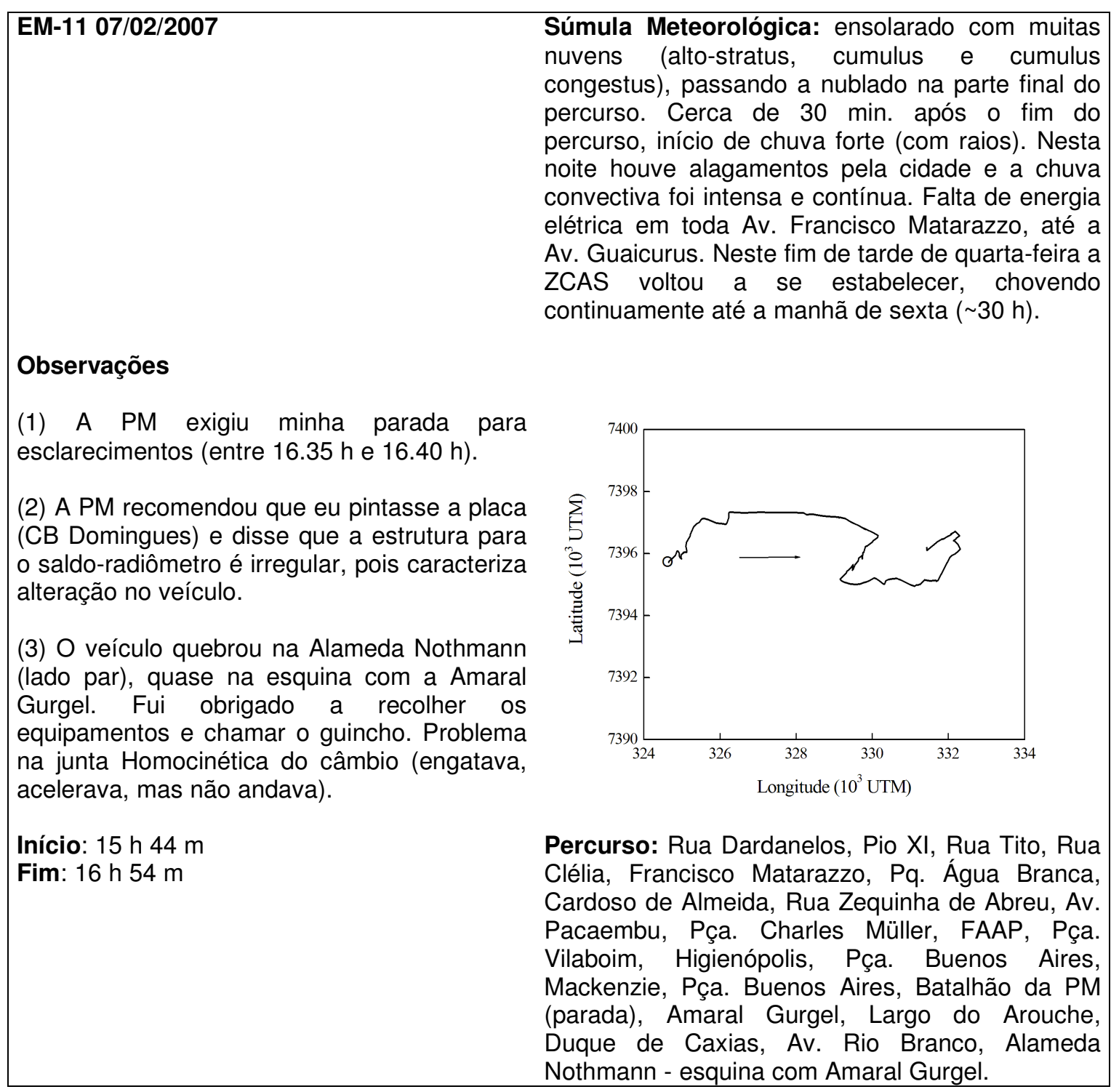




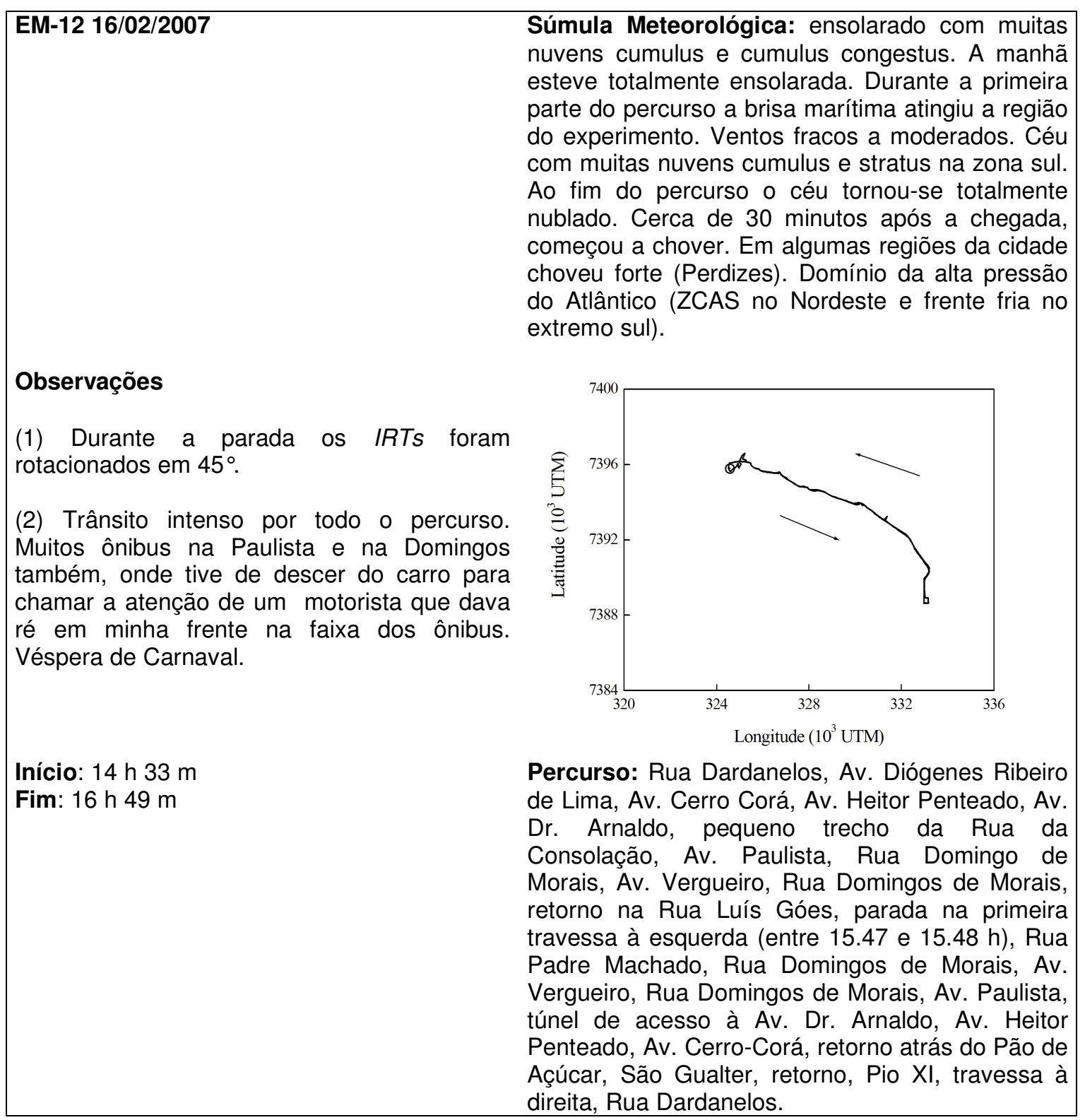




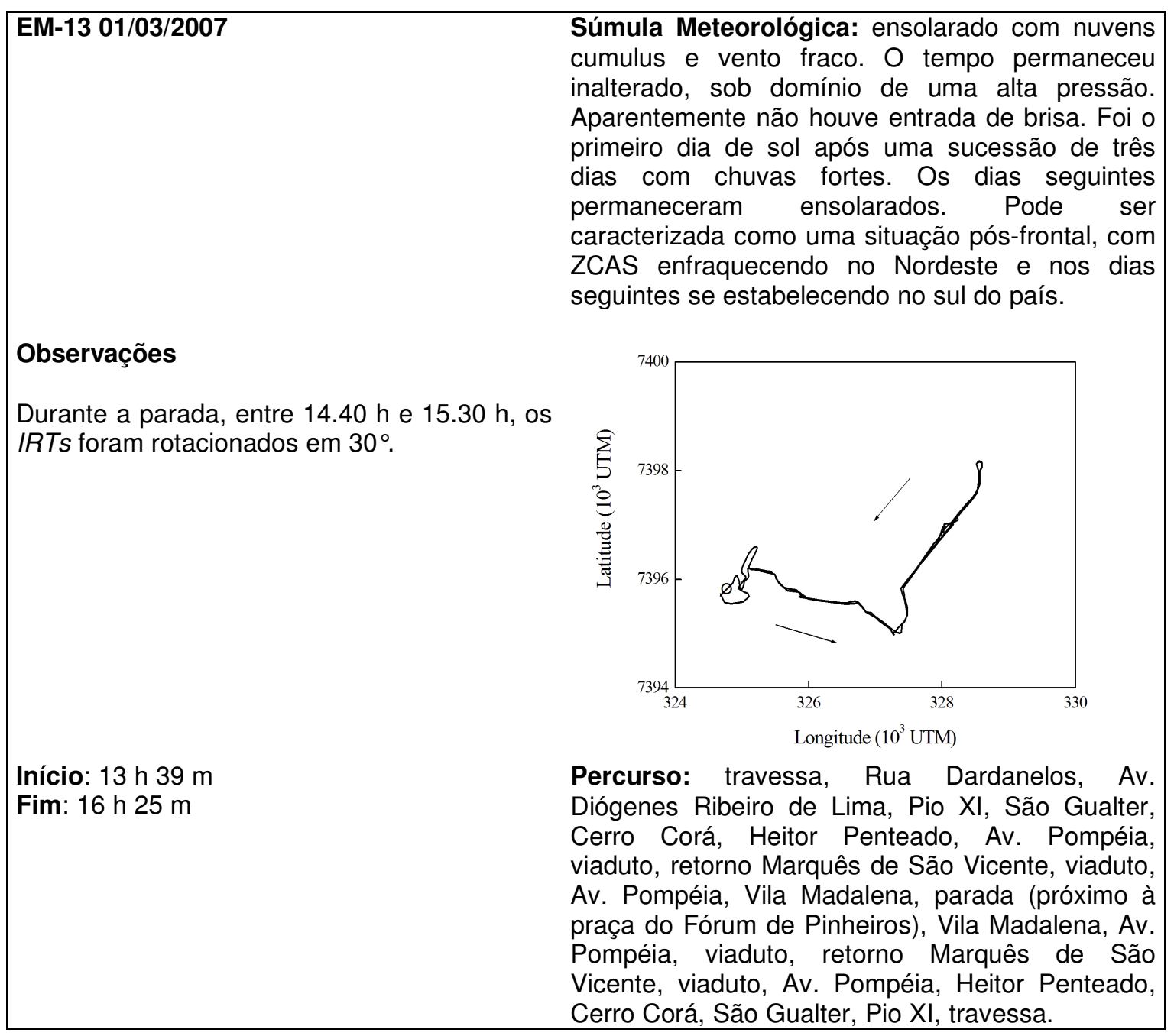




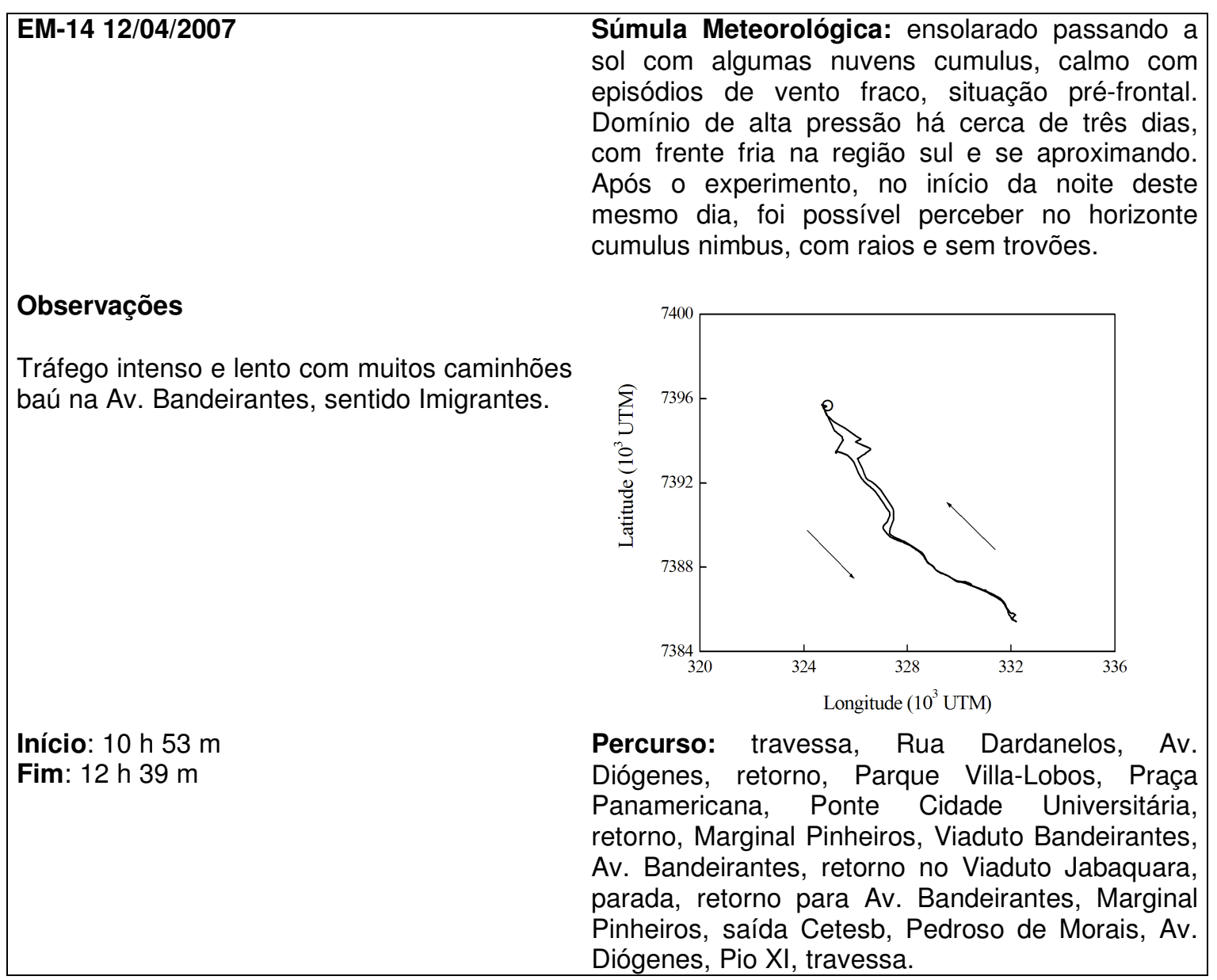




\begin{tabular}{|ll|}
\hline EM-15 22/04/2007 & Súmula Meteorológica: muitas nuvens stratus, \\
passando a ensolarado ainda com muitos stratus. \\
Choveu forte na tarde anterior ena narde posterior. \\
Situação típica de verão. Baixa pressão sobre o \\
Planalto Central do Brasil. \\
Observações \\
Parada no bairro Jaguaré em Osasco para \\
tomada de informações e localização.
\end{tabular}




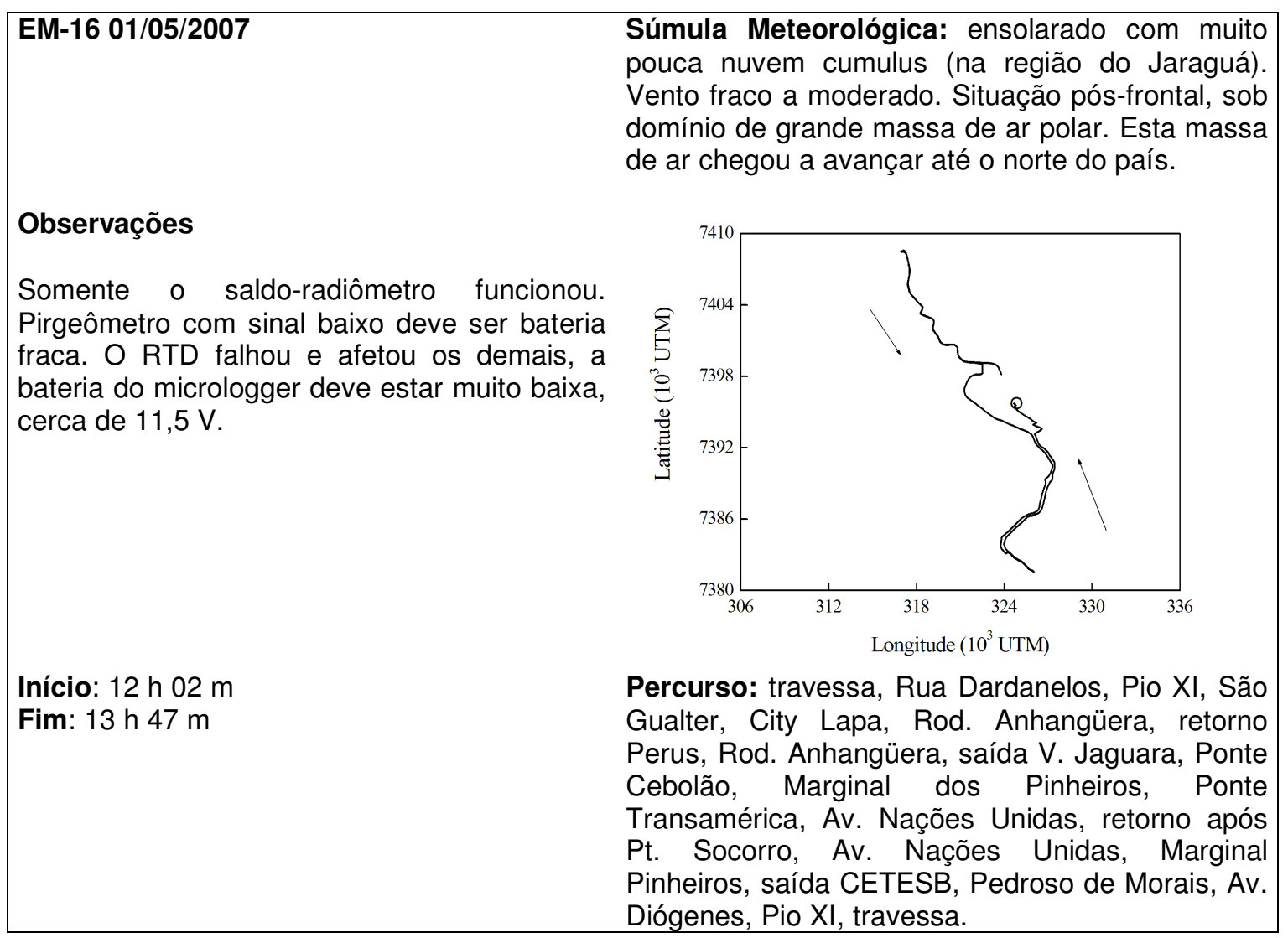




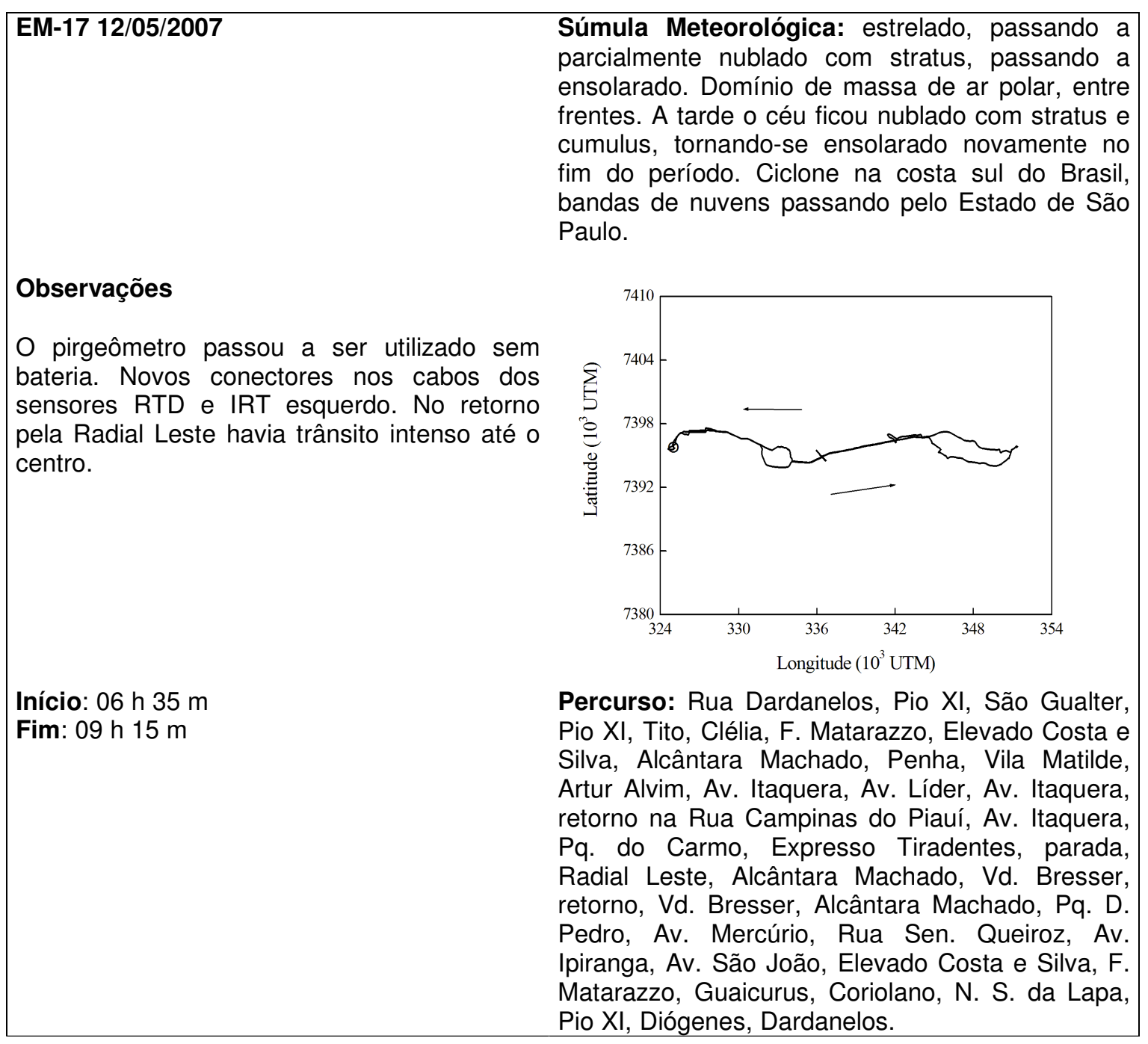




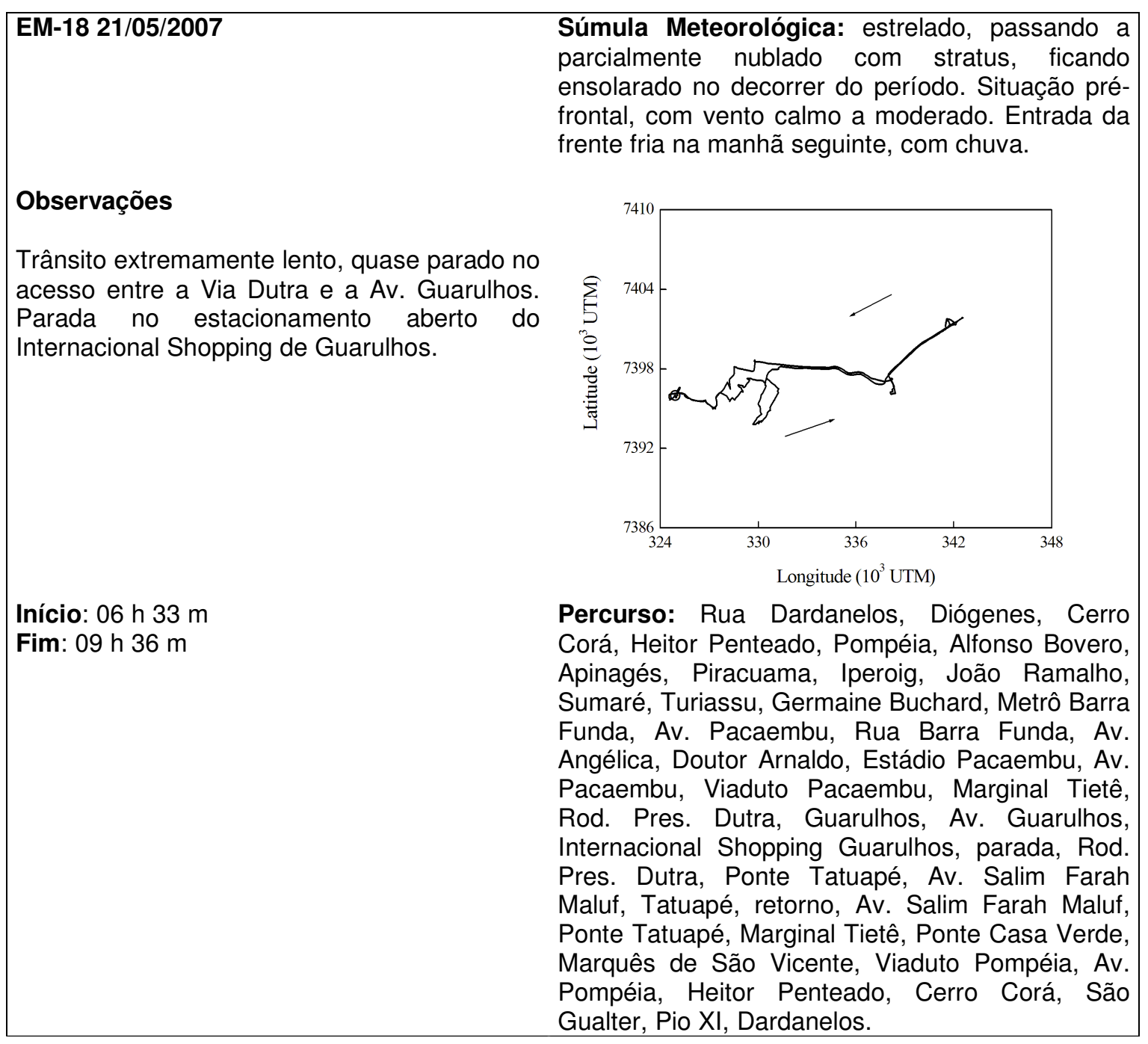




\begin{tabular}{|c|c|}
\hline EM-19 31/05/2007 & $\begin{array}{l}\text { Súmula Meteorológica: ensolarado com muito } \\
\text { cirrus-stratus. Vento moderado a calmo. Situação } \\
\text { pré-frontal, domínio de massa de ar frio trazida por } \\
\text { ciclone com nova frente fria se organizando na } \\
\text { Região Sul do país. }\end{array}$ \\
\hline $\begin{array}{l}\text { Observações } \\
\text { (1) Estrada Embu-Cotia com trechos }\end{array}$ & \\
\hline $\begin{array}{l}\text { áreas de mata. } \\
\text { (2) Parada em vaga de estacionamento } \\
\text { coberta, com telhas de zinco. } \\
\text { (3) Houve perda de sinal do saldo-radiômetro } \\
\text { em alguns instantes, aparentemente mau } \\
\text { contato na emenda do cabo. }\end{array}$ & 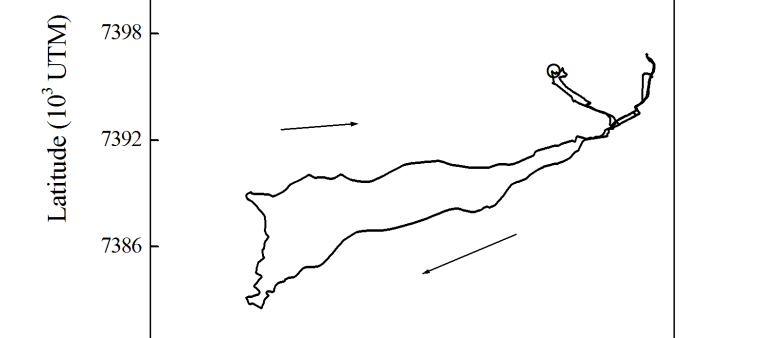 \\
\hline $\begin{array}{l}\text { (4) Perda de sinal do GPS no trajeto Eusébio } \\
\text { Matoso - Régis Bltencourt - Embu das Artes - } \\
\text { Raposo Tavares - Vital Brazil. }\end{array}$ & 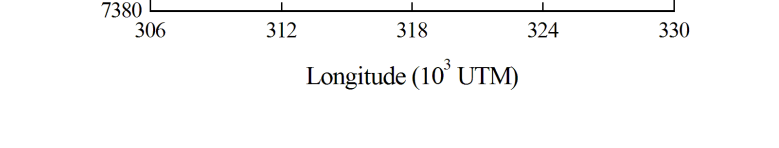 \\
\hline $\begin{array}{l}\text { Início: } 10 \text { h } 19 \text { m } \\
\text { Fim: } 16 \text { h } 08 \text { m }\end{array}$ & $\begin{array}{l}\text { Percurso: Rua Dardanelos, Diógenes, Pedroso de } \\
\text { Morais, Praça Panamericana, Pedroso, Teodoro } \\
\text { Sampaio, Av. Henrique Schaumann, Av. Sumaré, } \\
\text { retorno Palestra Itália, Av. Sumaré, Cardeal } \\
\text { Arcoverde, Eusébio Matoso, Francisco Morato, } \\
\text { Taboão da Serra, Régis Bitencourt, Embu das } \\
\text { Artes, Estrada vicinal Embu-Cotia, Raposo } \\
\text { Tavares, Vital Brazil, Viaduto Goldfaber, Rua } \\
\text { Butantã, Teodoro Sampaio, Henrique Schaumann, } \\
\text { Av. Sumaré, Rua Vargem do Cedro, Piracuama, } \\
\text { Iperoig, PARADA (Estacionamento Iperoig), } \\
\text { Ministro Gastão Mesquita, Av. Sumaré, Cardeal } \\
\text { Arcoverde, Teodoro Sampaio, Henrique } \\
\text { Schaumann, Av. Sumaré, retorno Palestra Itália, } \\
\text { Av. Sumaré, Cardeal Arcoverde, Largo da Batata, } \\
\text { Faria Lima, Pedroso de Morais, Diógenes, Pio XI, } \\
\text { Dardanelos. }\end{array}$ \\
\hline
\end{tabular}




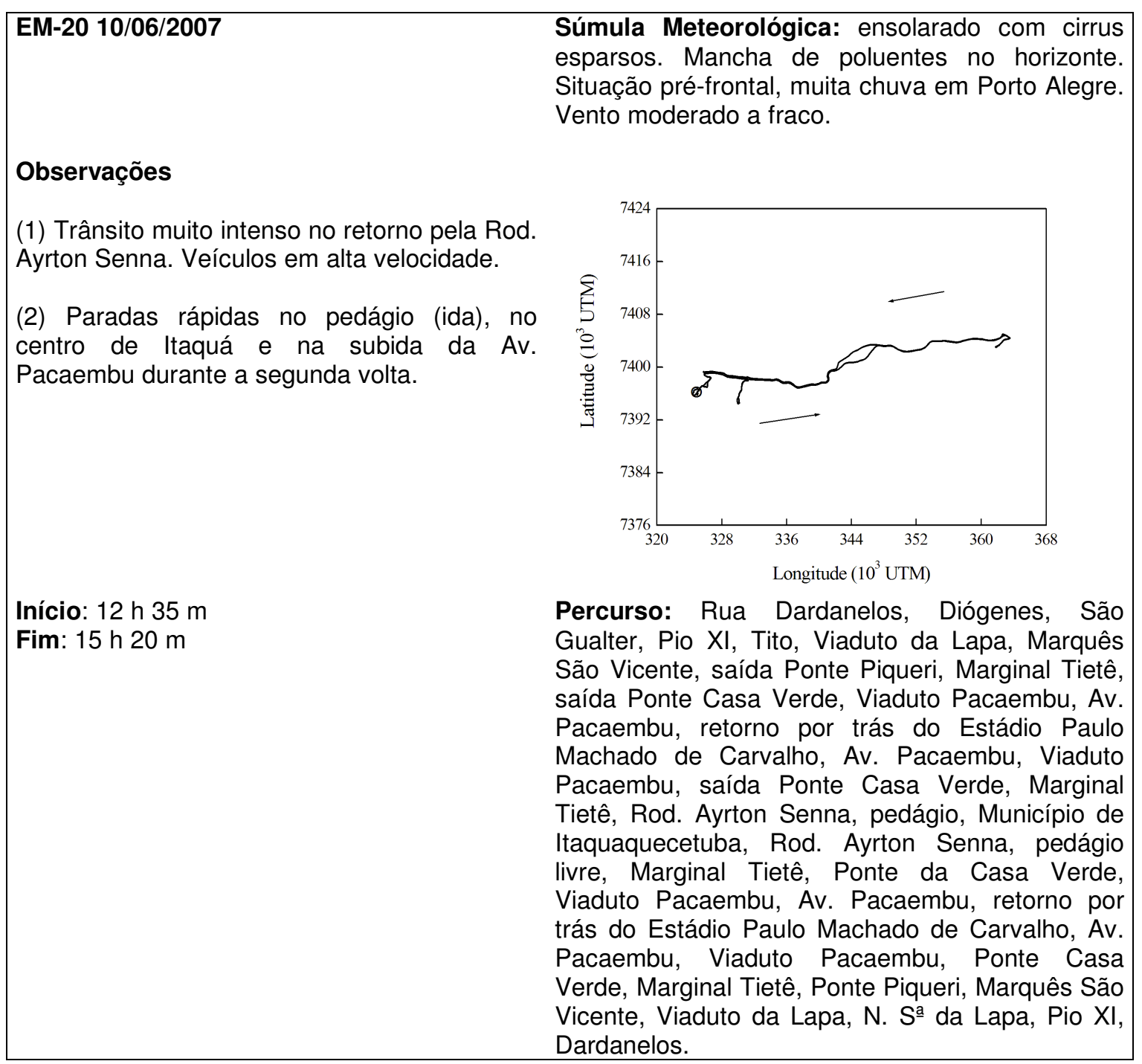




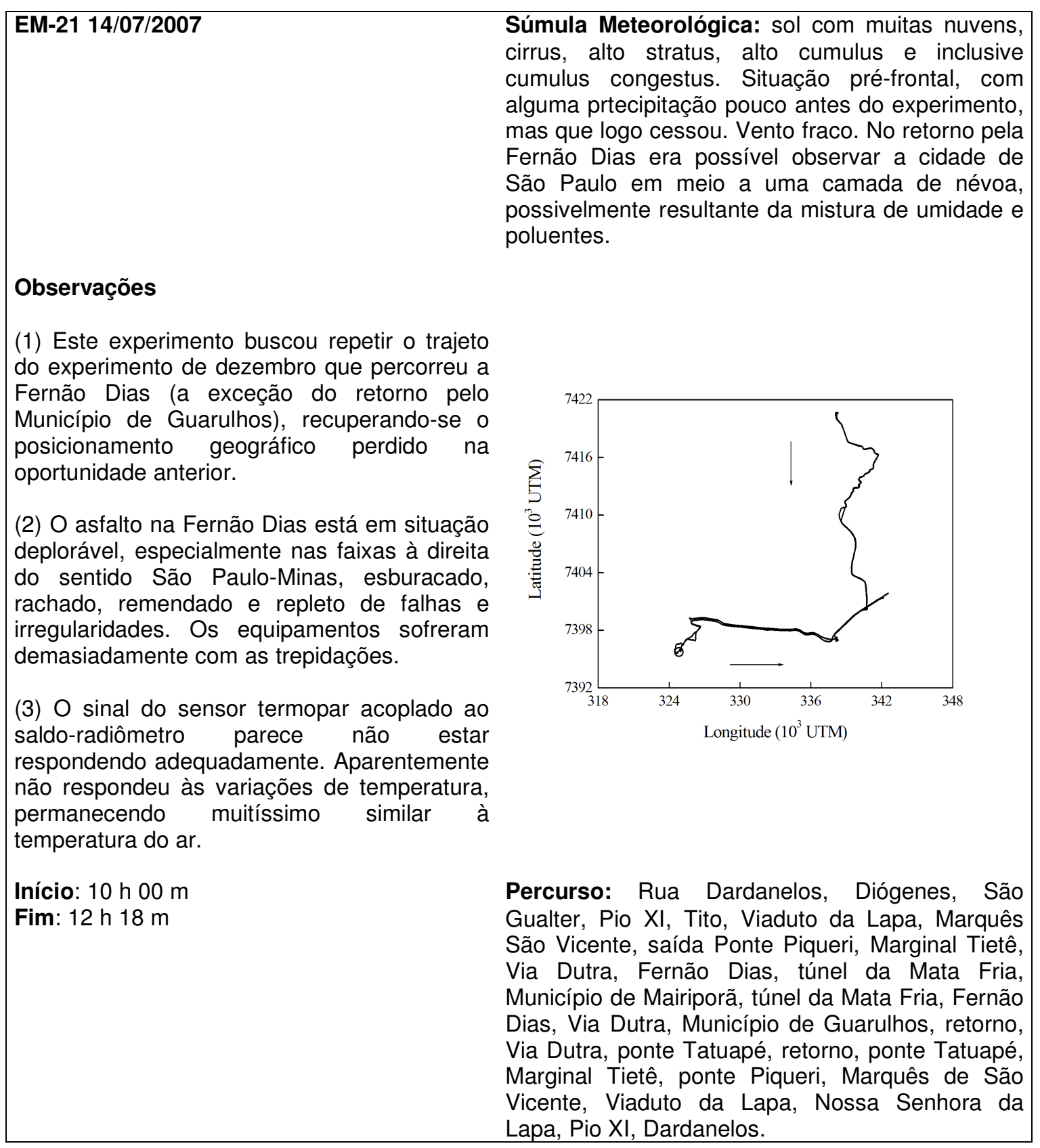




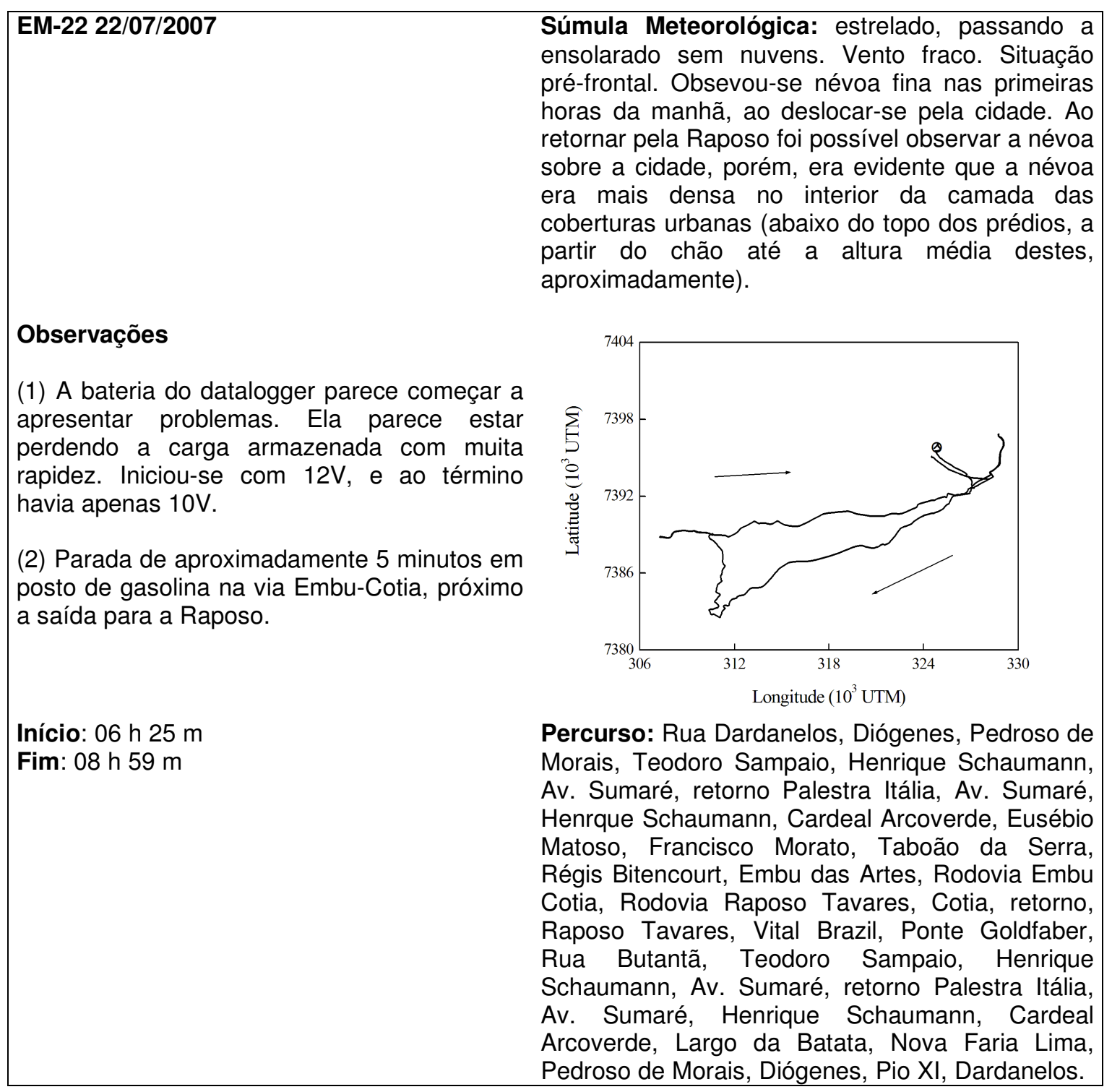




\begin{tabular}{|ll}
\hline EM-23 29/07/2007 & $\begin{array}{l}\text { Súmula Meteorológica: nublado com garoa, } \\
\text { passando a nublado com ligeiras aberturas de sol } \\
\text { e voltando a totalmente nublado. Situação pós- } \\
\text { frontal com domínio de forte massa de ar polar. } \\
\text { Ventos moderados, com forte infiltração de ar } \\
\text { marítimo. Muito frio no dia anterior, passando a } \\
\text { ensolarado no fim da tarde posterior. }\end{array}$ \\
Observações & \\
Áreas com ocupação típica da periferia no & \\
Tucuruvi e em Caieiras - Perus, entremeadas \\
por áreas com muita vegetação entre a \\
Estrada da Roseira, Fernão Dias e vias que \\
partiam da Represa de Mairiporã.
\end{tabular}




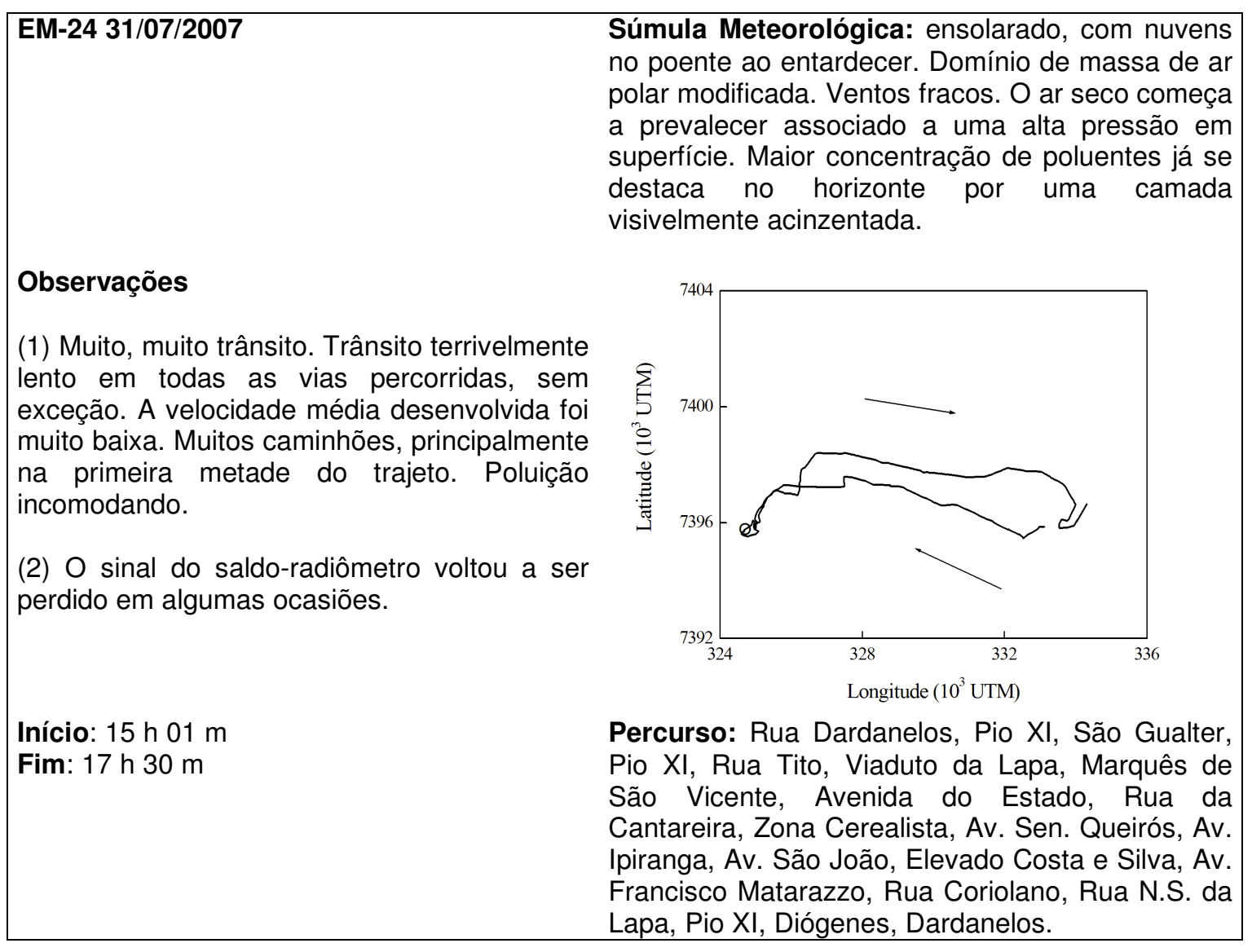




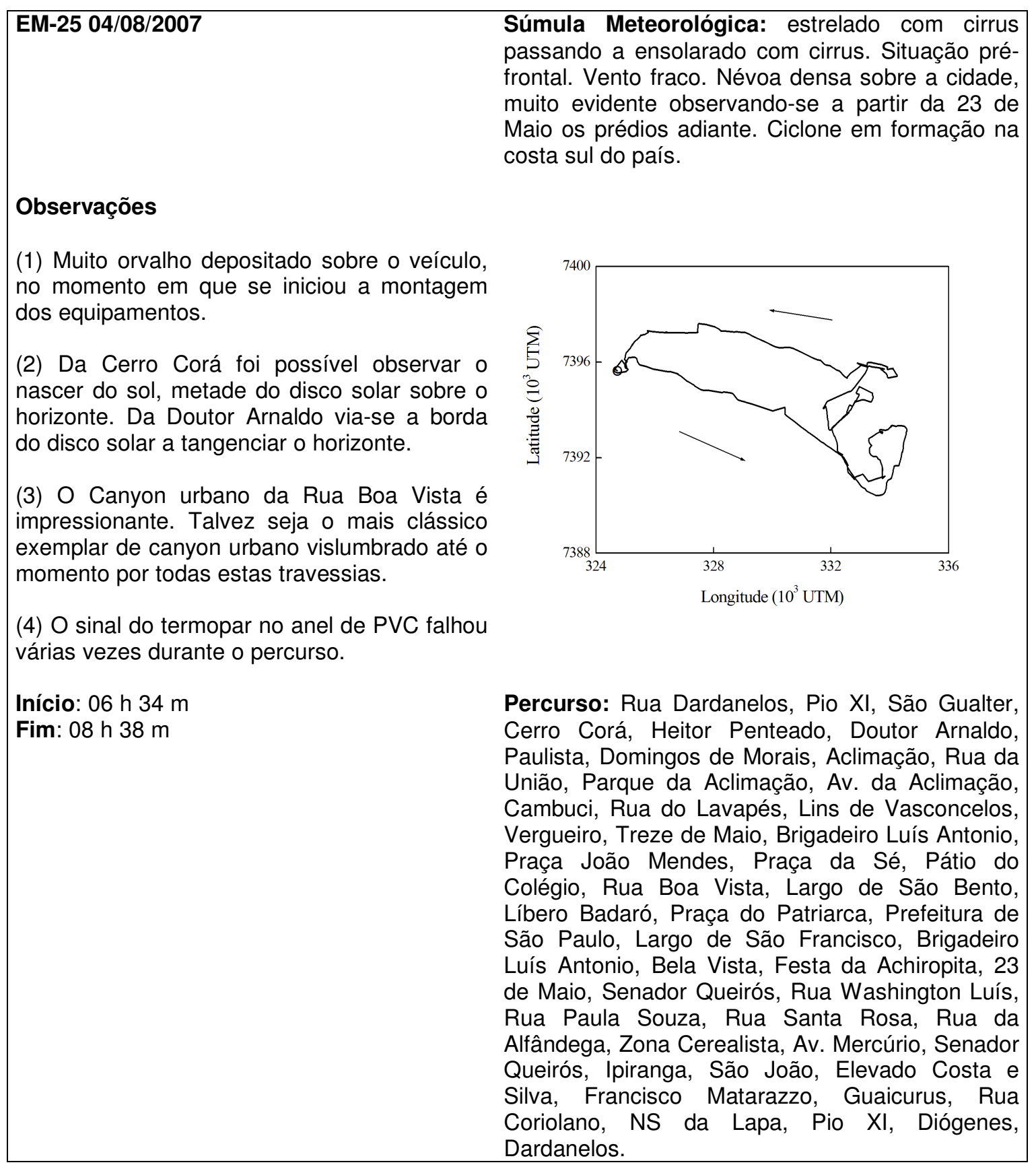




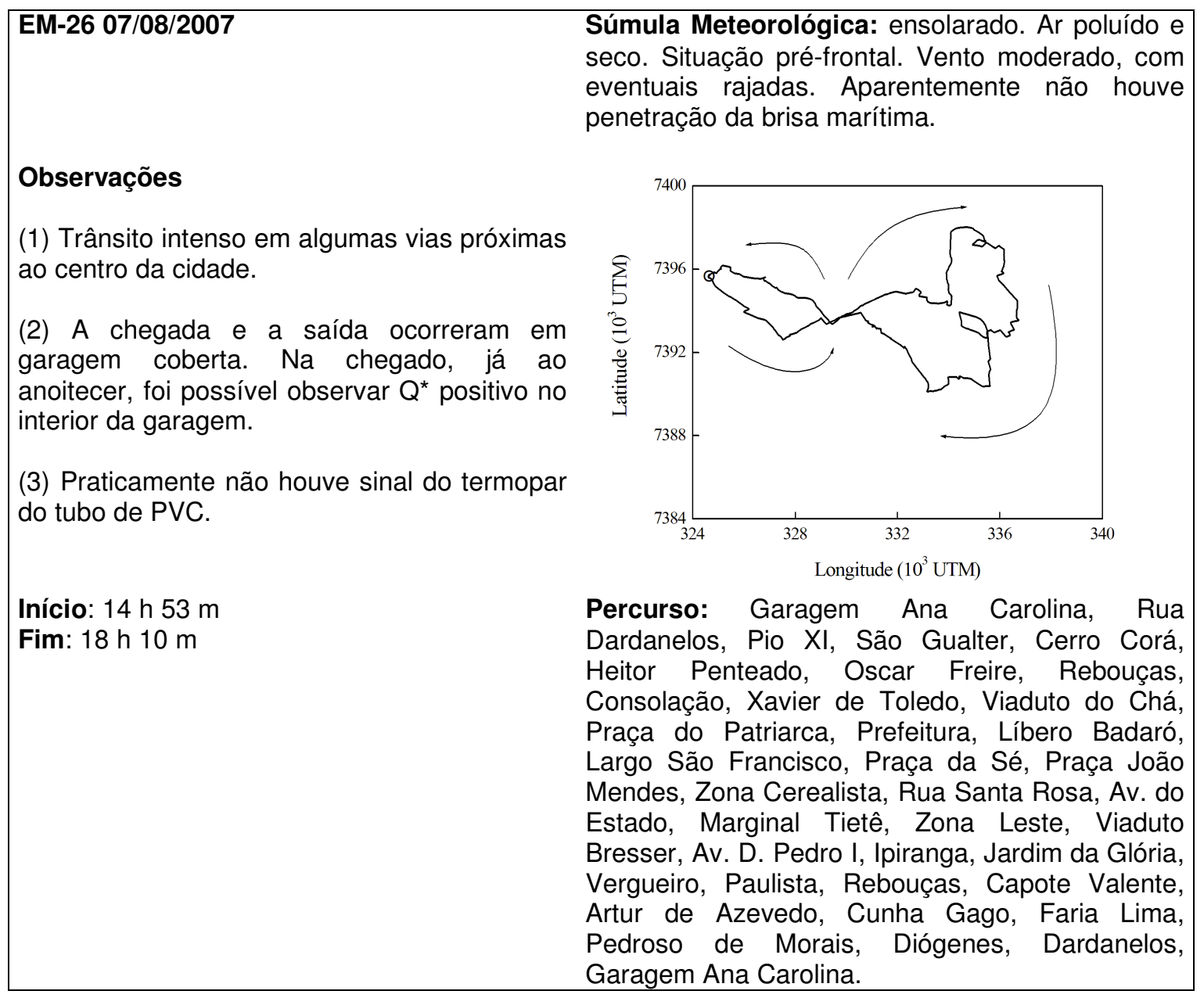




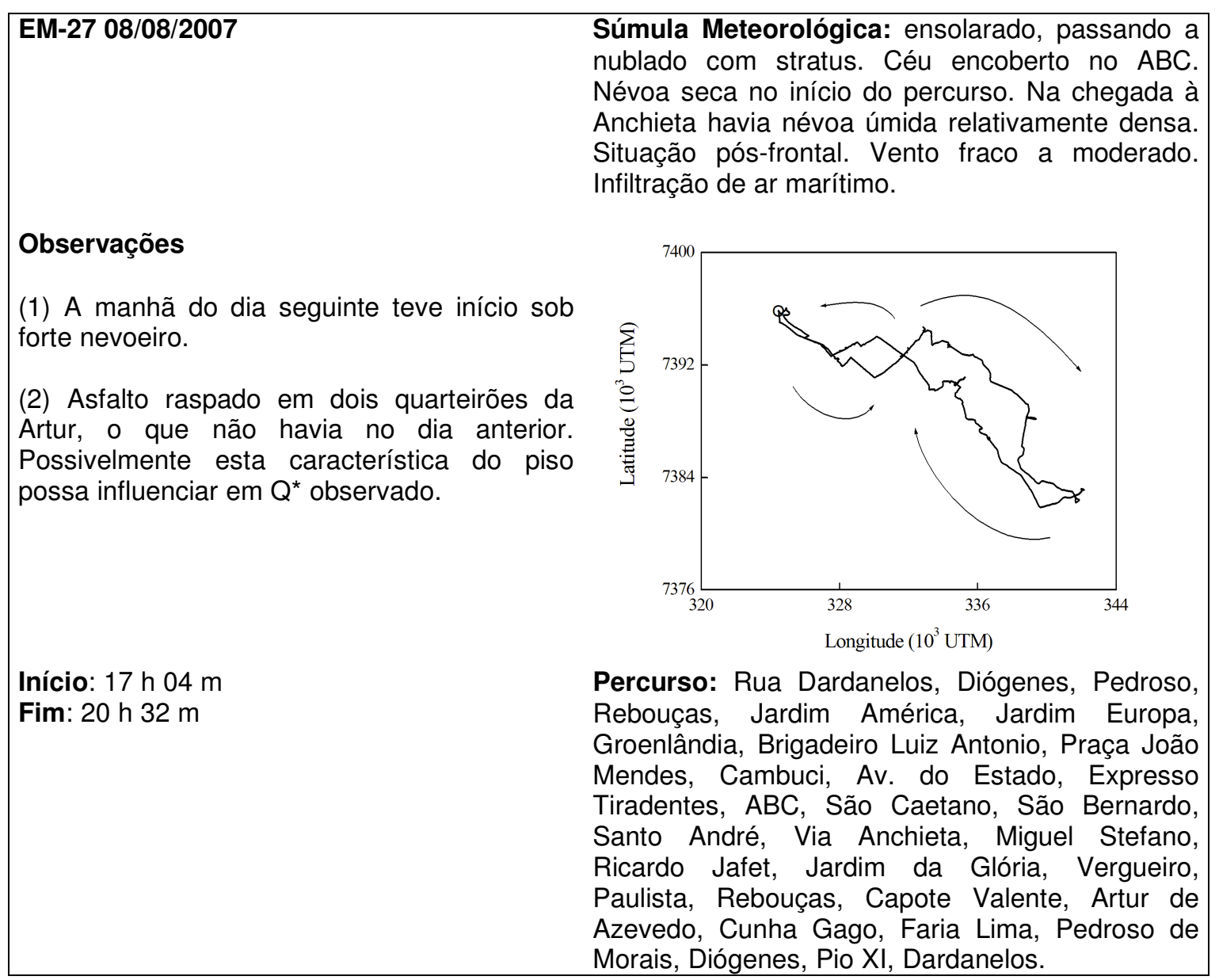




\begin{tabular}{|l|l|l|l|}
\hline EM-28 11/08/2007 & $\begin{array}{l}\text { Súmula Meteorológica: sol com muitas nuvens } \\
\text { (altocumulus e altostratus) passando a nublado } \\
\text { (stratus). Entrada de frente fria durante a } \\
\text { realização do experimento. Vento fraco a } \\
\text { moderado. }\end{array}$ \\
Observações & \\
(1) A memória do GPS não foi suficiente para \\
armazenar todo o percurso (de 150 km e 4 \\
horas e meia). A etapa inicial até parte da Av. \\
Assis Ribeiro foi perdida.
\end{tabular}


EM-29 13/08/2007

\section{Observações}

(1) A memória do GPS foi mais uma vez insuficiente para armazenar todo o percurso (de $140 \mathrm{~km}$ e 3 horas e meia). A etapa inicial até a Marginal Tietê foi perdida.

(2) Nevoeiro muito intenso em todo o percurso pela Estrada dos Romeiros, especialmente nos fundos do vale do Tietê. $\mathrm{Na}$ estrada propriamente, o nevoeiro cobriu boa parte da travessia entre Santana e Pirapora, até a estrada para Cabreúva. Visibilidade muito reduzida, a cerca de $100 \mathrm{~m}$. No retorno ainda havia nevoeiro nos mesmos setores, agora mais fraco.

(3) Foi possível atravessar o nevoeiro com os instrumentos. Até o momento foi o episódio com nevoeiro mais intenso.

(4) Na chegada pela Anhangüera era possível avistar a cidade imersa em névoa.

(5) Muito trânsito (parado) na parte final da Anhangüera.

Início: 06 h $20 \mathrm{~m}$

Fim: 09 h 13 m
Súmula Meteorológica: estrelado com stratus esparsos, passando a ensolarado. Situação pósfrontal. Vento moderado com rajadas.

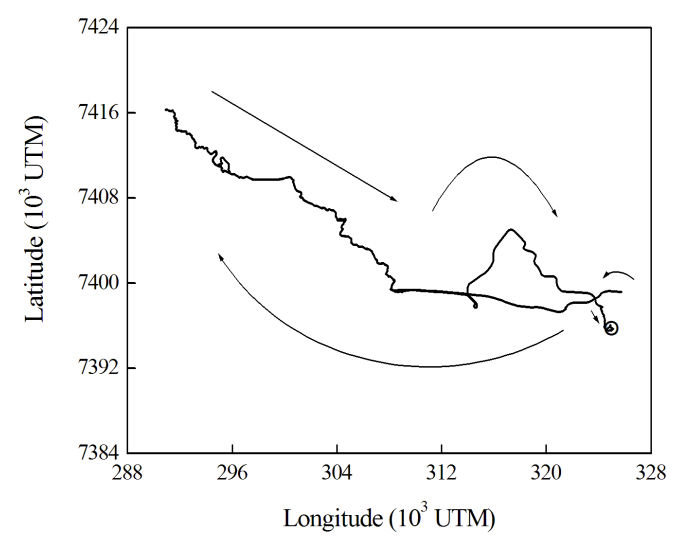

Percurso: Rua Dardanelos, Diógenes, Pio XI, Rua Tito, Clélia, Francisco Matarazzo, entorno do Parque da Água Branca, Francisco Matarazzo, Viaduto Pompéia, Ponte Júlio de Mesquita, Marginal Tietê, Castelo Branco, Barueri, Estrada dos Romeiros, Santana do Parnaíba, Pirapora do Bom Jesus, Cabreúva, retorno, Estrada dos Romeiros, Pirapora do Bom Jesus, Santana do Parnaíba, Barueri, Castelo Branco, Rodoanel, Anhangüera, City Lapa, Diógenes, Pio XI, Dardanelos. 


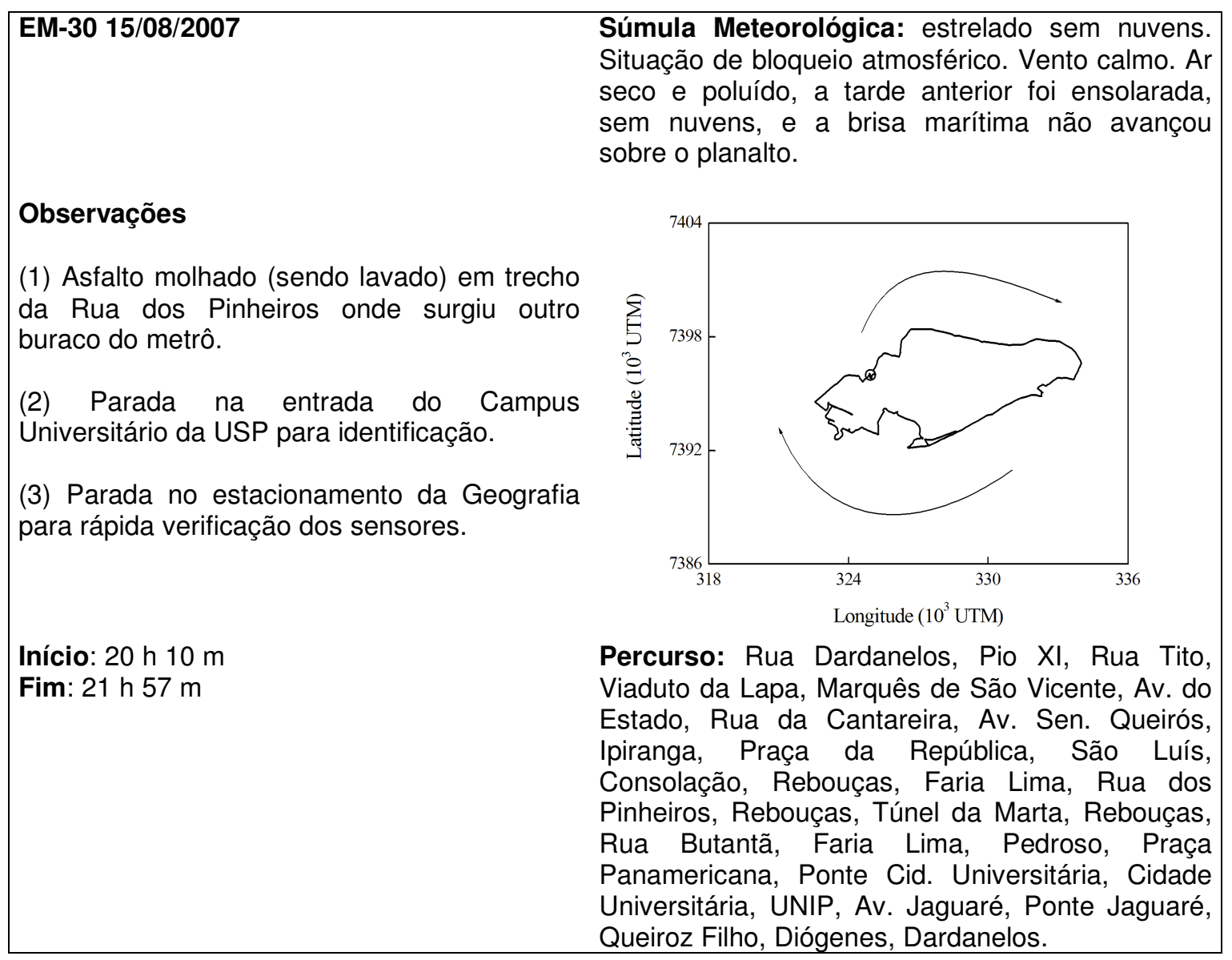




\begin{tabular}{|c|c|}
\hline EM-31 12/09/2007 & $\begin{array}{l}\text { Súmula Meteorológica: ensolarado, sem nuvens. } \\
\text { Ar seco e poluído. Domínio da Alta do Atlântico há } \\
\text { quase uma semana, situação de bloqueio } \\
\text { atmosférico. Vento fraco a moderado. }\end{array}$ \\
\hline $\begin{array}{l}\text { Observações } \\
\text { (1) Névoa seca sobre a cidade. } \\
\text { (2) Parada na Oficina do Sérgio onde é feita a } \\
\text { manutenção do veículo. Apresentação dos } \\
\text { equipamentos. } \\
\text { (3) Várias áreas favelizadas nos limites entre } \\
\text { São Paulo e Taboão. Difícil acesso ao interior } \\
\text { da favela, vias muito estreitas, em geral não } \\
\text { permitindo a passagem do veículo. Difícil } \\
\text { manobra para retorno. Em geral percorre-se o } \\
\text { seu perímetro. Algo semelhante aos parques } \\
\text { urbanos, em termos de dificuldade de acesso } \\
\text { com o veículo. }\end{array}$ & 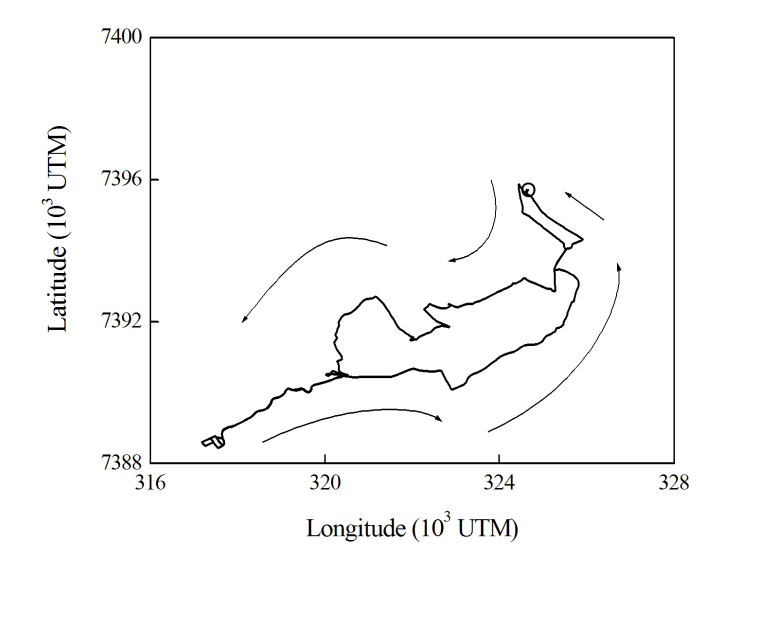 \\
\hline $\begin{array}{l}\text { Início: } 15 \text { h } 31 \text { m } \\
\text { Fim: } 17 \text { h } 29 \text { m }\end{array}$ & $\begin{array}{l}\text { Percurso: Garagem Ana Carolina, Rua } \\
\text { Dardanelos, Diógenes, Pedroso de Morais, Praça } \\
\text { Panamericana, Ponte Cidade Universitária, Cidade } \\
\text { Universitária, Av. Corifeu de Azevedo Marques, } \\
\text { Av. Otacílio Tomanik, Parada na Oficina SR (entre } \\
\text { torno de } 15.50 \mathrm{~h} \text { e } 16.10 \mathrm{~h} \text { ), Av. Otacílio Tomanik, } \\
\text { Av. Rio Pequeno, Rod. Raposo Tavares, Av. Eiras } \\
\text { Garcia, Educandário, Taboão da Serra, Favela, } \\
\text { retorno, Educandário, Av. Eiras Garcia, Raposo, } \\
\text { Av. Eliseu de Almeida, Rua Camargo, Ponte } \\
\text { Cidade Universitária, Praça Panamericana, Panana } \\
\text { Diógenes, Dardanelos, Garagem Ana Carolina. }\end{array}$ \\
\hline
\end{tabular}




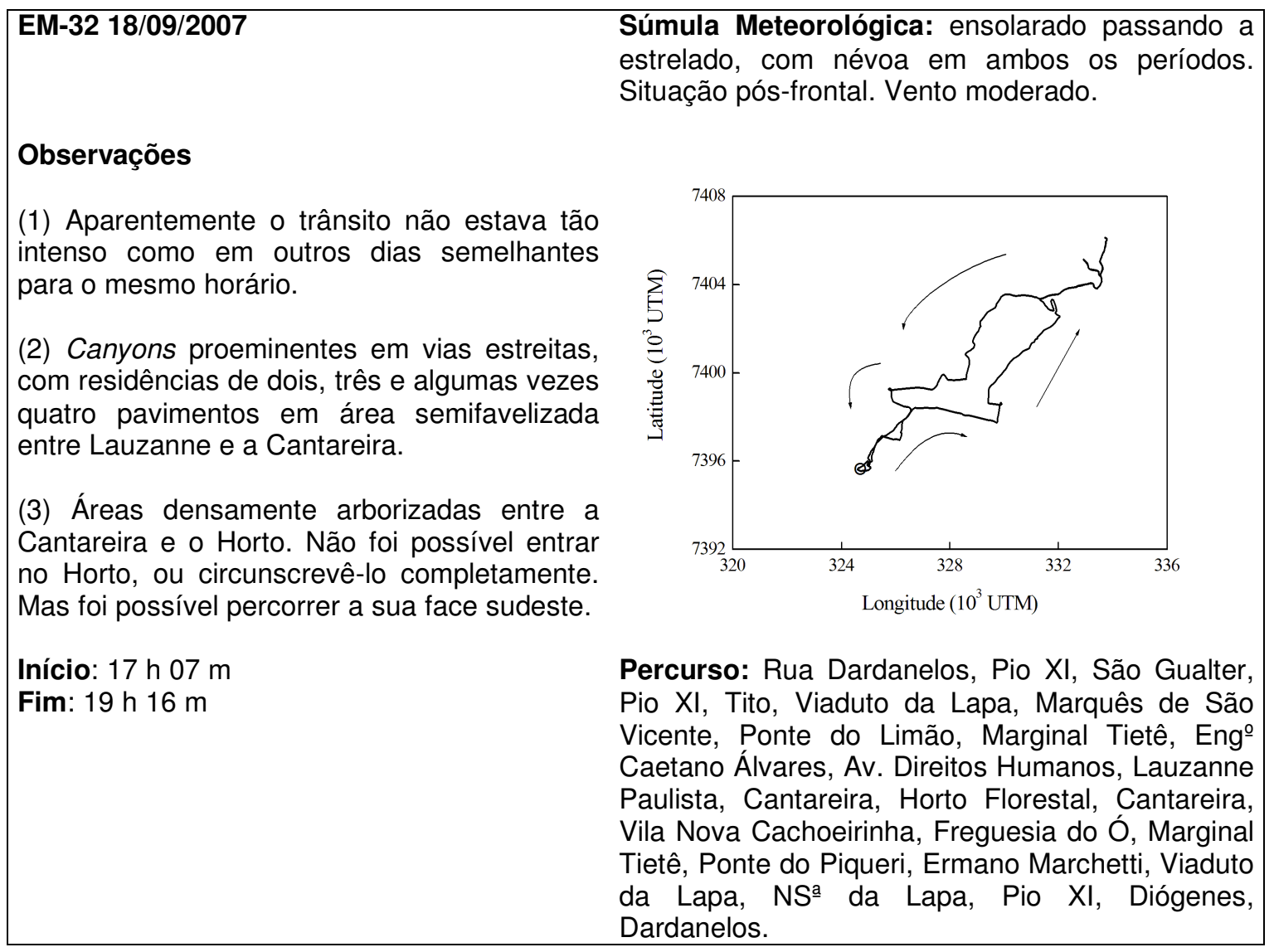




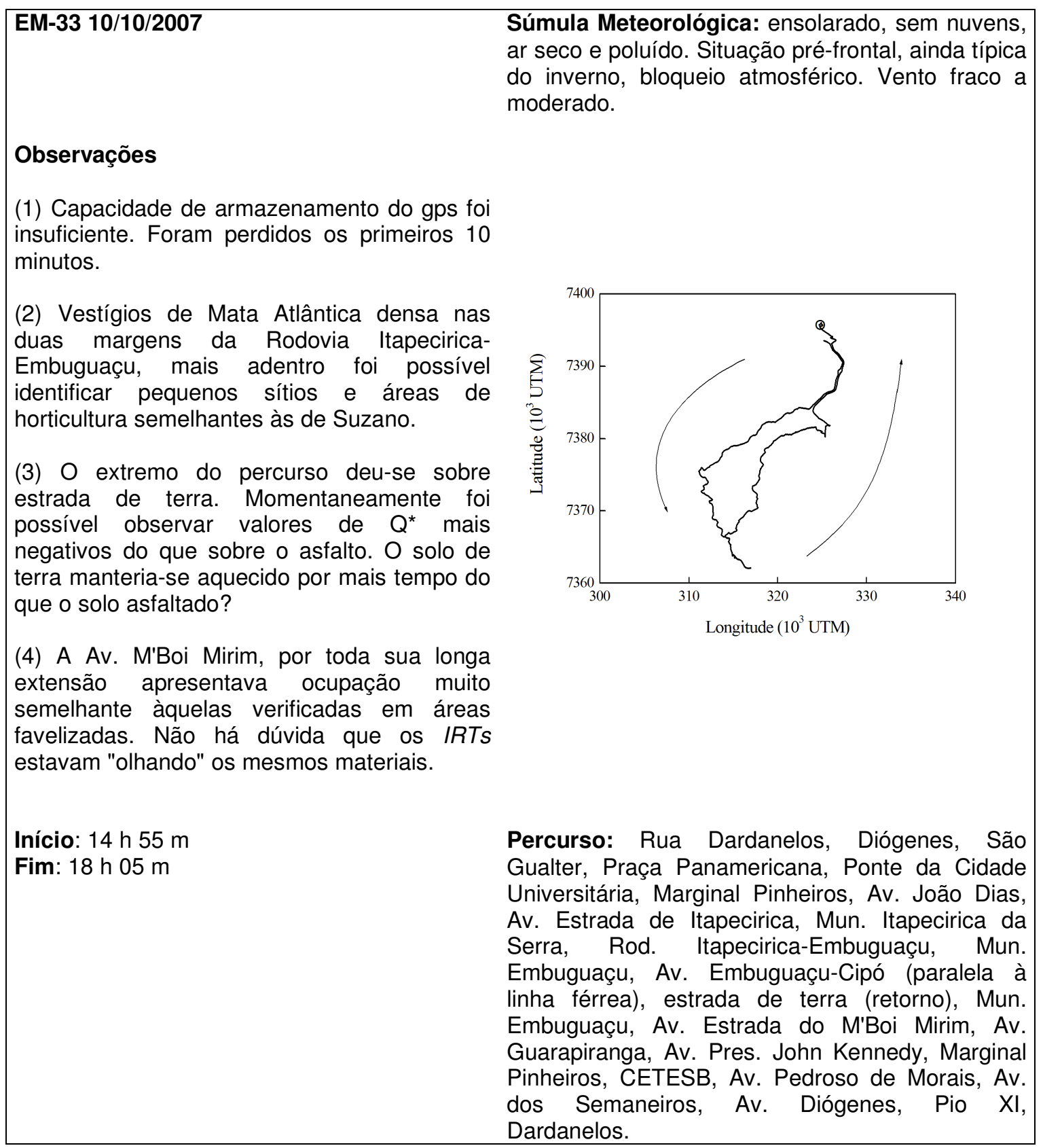


EM-34 21/10/2007

\section{Observações}

(1) Linha de Instabilidade atravessou a região de estudo, sem causar chuvas mas com rajadas de vento, cerca de duas horas antes do início do experimento.

(2) Conector do termopar do anel com falhas na fixação. Tentou-se a posição par2 ao invés da original par1. A extremidade do conector soltou-se no interior do ponto de conexão, não sendo possível removê-la. Mesmo assim, com - conector avariado, aparentemente foi possível registrar este sinal na posição de registro invertida.

(3) Desta vez foi possível cruzar o interior da Serra da Cantareira no meridional, após em outras ocasiões ter-se percorrido suas vertentes sul e norte no sentido zonal.

(4) Aparentemente a umidade do ar aumentou consideravelmente, seguindo-se a mudança de estação. Fortes chuvas convectivas, com rajadas de vento na noite posterior ao experimento. Com queda de temperatura no dia seguinte.

Início: 07 h $02 \mathrm{~m}$

Fim: 10 h 33 m
Súmula Meteorológica: nublado com stratus e cumulus, passando a ensolarado com cirrus em praticamente todo o percurso. Situação pré-frontal. Vento moderado.

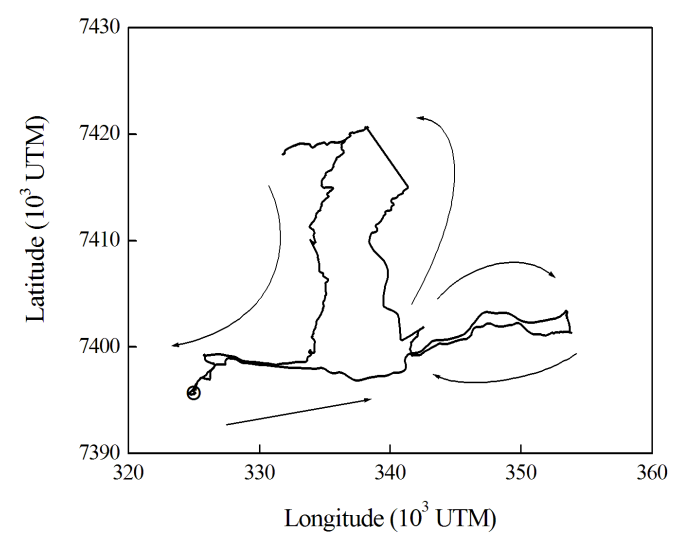

Percurso: Rua Dardanelos, Pio XI, São Gualter, Pio XI, Tito, Viaduto da Lapa, Marquês de São Vicente, saída Ponte da Freguesia, Marginal Tietê, Rod. Ayrton Senna, após saída Itaqua retorno sentido Zona Leste, São Miguel Paulista, Av. Assis Ribeiro, Ponte do Imigrante Nordestino, Guarulhos, Via Dutra, Fernão Dias, Mairiporã, Rod. Mairiporã-Franco da Rocha, Represa de Mairiporã, Estrada da Roseira, Serra da Cantareira, Zona Norte, saída Ponte da Casa Verde, Marginal Tietê, Ponte do Piqueri, Ermano Marchetti, Viaduto da Lapa, NS ${ }^{a}$ da Lapa, Pio XI, Diógenes, Dardanelos. 


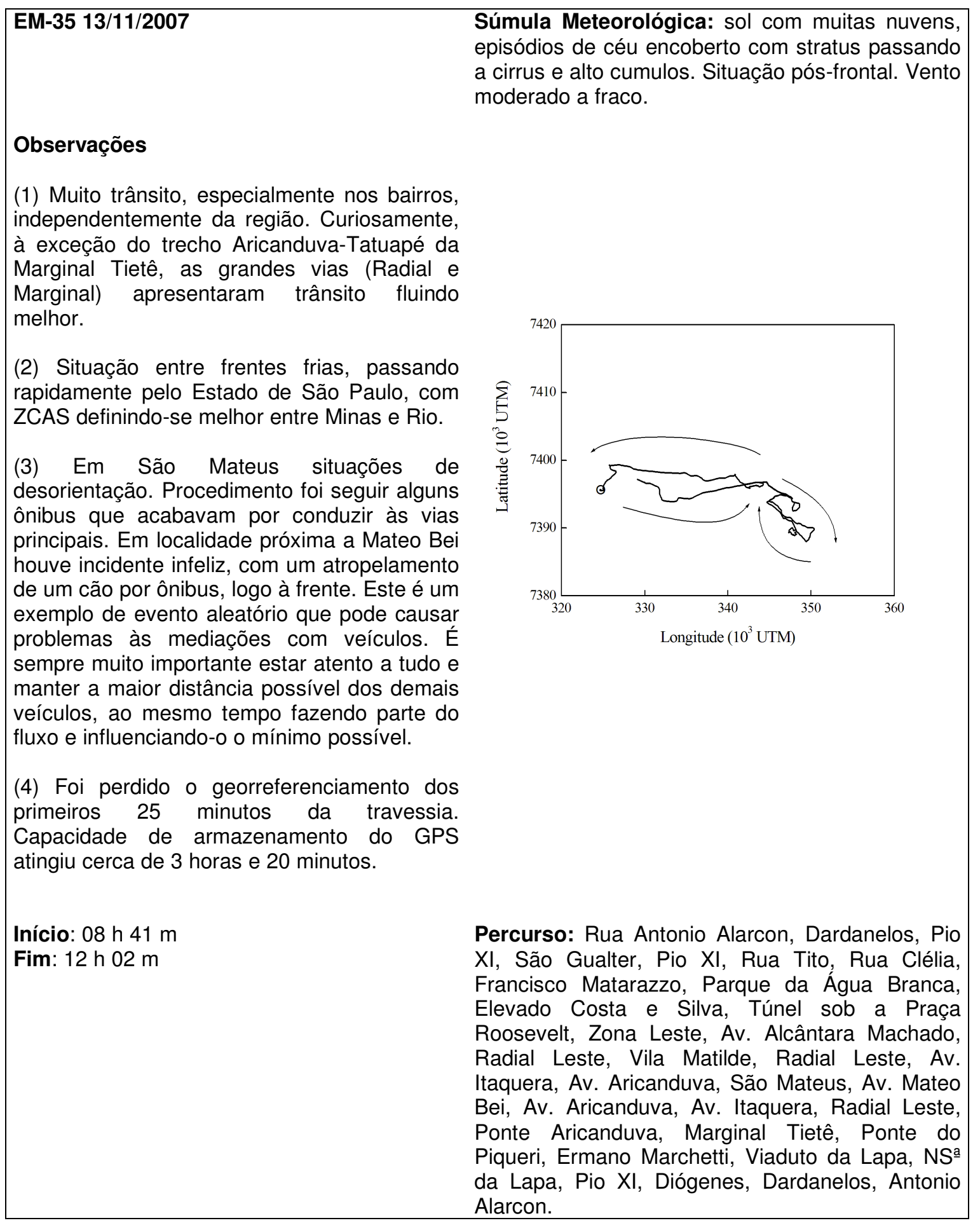




\begin{tabular}{|c|c|}
\hline EFX-1 22/03/2007 & $\begin{array}{l}\text { Súmula Meteorológica: nublado, com momentos } \\
\text { de chuvisco seguidos a breves e pequenas } \\
\text { aberturas de céu. Situação frontal. Frente fria } \\
\text { passando distante, na altura do litoral paulista. Os } \\
\text { dias anteriores e posterior foram ensolarados. } \\
\text { Predominância de alta pressão com ZCAS entre } \\
\text { Rio e Minas. Vento fraco com alguns episódios de } \\
\text { moderado. Durante a manhã até momentos antes } \\
\text { ao experimento houve alguns momentos } \\
\text { ensolarados, mas durante o experimento o céu } \\
\text { permaneceu basicamente nublado com presença } \\
\text { de stratus e altocumulus. }\end{array}$ \\
\hline \multicolumn{2}{|l|}{ Observações } \\
\hline \multicolumn{2}{|c|}{$\begin{array}{l}\text { (1) Foram feitas mensurações nas seguintes superfícies, na ordem do arquivo de dados: árvore, } \\
\text { parede, asfalto e ar. Os canais } 01,02,03 \text { e } 04 \text { registraram as superfícies expostas ao céu. Os } \\
\text { canais } 08,09,10,11 \text { registraram as superfícies sombreadas pela árvore. O registro } 15 \\
\text { corresponde à temperatura do micrologger usada como referência. }\end{array}$} \\
\hline \multicolumn{2}{|c|}{$\begin{array}{l}\text { (2) A Rua Sebastião Cortês apresenta características muito interessantes. Tem a forma de uma } \\
\text { cunha com face sudeste. As observações foram feitas na parede com face sudeste, próximo ao } \\
\text { setor central da cunha. É uma rua de pouco movimento e apresenta grande parte das } \\
\text { características encontradas na cidade: asfalto, calçada, paredes diversas com cimento, e pastilhas, }\end{array}$} \\
\hline $\begin{array}{l}\text { Início: } 13 \text { h } 00 \text { m } \\
\text { Fim: } 16 \text { h } 00 \text { m }\end{array}$ & $\begin{array}{l}\text { Local: Rua Sebastião Cortês, bairro de Perdizes, } \\
\text { início e fim na Rua Campevas, próximo à Avenida } \\
\text { Sumaré. }\end{array}$ \\
\hline
\end{tabular}




\begin{tabular}{|c|c|}
\hline EFX-2 28/06/2007 & $\begin{array}{l}\text { Súmula Meteorológica: ensolarado com muitas } \\
\text { nuvens stratus e cumulus. Situação frontal com } \\
\text { chuva nas primeiras horas da manhã. A chuva } \\
\text { estava associada a uma linha pré-frontal e durante } \\
\text { a manhã a nebulosidade foi diminuindo. Ao fim da } \\
\text { tarde a nebulosidade aumentou, o céu ficou } \\
\text { nublado e voltou a chover no início da noite devido } \\
\text { ao avanço do sistema frontal. Vento fraco, com } \\
\text { alguns episódios de brisa no decorrer da tarde. }\end{array}$ \\
\hline \multicolumn{2}{|l|}{ Observações } \\
\hline \multicolumn{2}{|c|}{$\begin{array}{l}\text { (1) Foram feitas mensurações nas seguintes superfícies, na ordem do arquivo de dados: árvore, } \\
\text { parede, asfalto e ar. Os canais } 01,02,03 \text { e } 04 \text { registraram as superfícies expostas ao céu. Os } \\
\text { canais } 08,09,10,11 \text { registraram as superfícies sombreadas pela árvore. O registro } 15 \\
\text { corresponde à temperatura do micrologger usada como referência. }\end{array}$} \\
\hline \multicolumn{2}{|c|}{$\begin{array}{l}\text { (2) O chão, especialmente o asfalto, ainda estava úmido nas áreas sombreadas devido à chuva da } \\
\text { manhã. }\end{array}$} \\
\hline \multicolumn{2}{|c|}{$\begin{array}{l}\text { (3) Ao contrário do que se verificou em março, agora já no inverno, o trecho mais zonal da rua } \\
\text { onde ocorreu o experimento, torna-se totalmente sombreado pelos prédios já desde o início da } \\
\text { tarde. }\end{array}$} \\
\hline \multicolumn{2}{|c|}{$\begin{array}{l}\text { (4) Aparentemente verificou-se uma tendência de aumento da temperatura nos episódios de brisa. } \\
\text { Provavelmente o local observado tornou-se um poço de ar frio, e a brisa advectava ar quente dos } \\
\text { setores da cidade que estavam sob incidência dos raios solares e da maior atividade humana. }\end{array}$} \\
\hline \multicolumn{2}{|c|}{$\begin{array}{l}\text { (5) As atividades observadas no local de estudo são atenuadas em relação a outros setores } \\
\text { adjacentes, como a Av. Sumaré por exemplo. Mas mesmo assim, observou-se a circulação de } \\
\text { pedestres e veículos no local. }\end{array}$} \\
\hline $\begin{array}{l}\text { Início: } 11 \text { h } 10 \text { m } \\
\text { Fim: } 15 \text { h } 30 \text { m }\end{array}$ & $\begin{array}{l}\text { Local: Rua Sebastião Cortês, bairro de Perdizes, } \\
\text { início e fim na Rua Campevas, próximo à Avenida } \\
\text { Sumaré. }\end{array}$ \\
\hline
\end{tabular}




\begin{tabular}{|ll}
\hline EFX-3 23/08/2007 & Súmula Meteorológica: totalmente nublado, com \\
nevoeiro denso e baixo, cobrindo os andares mais \\
altos dos edifícios, passando a ensolarado. \\
Situação de bloqueio atmosférico. Ar muito seco e \\
poluído. Muitos casos de gripe. Ocorrência de \\
orvalho sobre os veículos nas primeiras horas da \\
manhã, totalmente evaporado em torno das 9 \\
horas. Vento calmo, com episódios de brisa a \\
partir da incidência direta dos primeiros raios de \\
sol, após as 8 horas.
\end{tabular}

\section{Observações}

(1) Foram feitas mensurações nas seguintes superfícies, na ordem do arquivo de dados: árvore, parede, asfalto e ar. Os canais 01, 02, 03 e 04 registraram as superfícies expostas ao céu. Os canais $08,09,10,11$ registraram as superfícies abaixo das copas das árvores. O registro 15 corresponde à temperatura do micrologger usada como referência.

(2) A parede exposta ao céu, e que foi monitorada, permaneceu sempre na sombra de árvores próximas.

(3) A área de estudo ainda esteve sob domínio de muitas sombras (prédios e árvores), devido ainda à elevada declinação solar.

(4) O asfalto exposto e que foi monitorado, acabou ficando sob incidência direta dos raios solares entre 9 e 10 horas, mas entre 10 e 11 horas houve o avanço das sombras das árvores.

(5) Aparentemente houve um mínimo acentuado na temperatura do ar abaixo das copas, medida sobre a cobertura do veículo. Provavelmente resultante do fluxo de calor latente para a atmosfera, a partir da superfície do veículo, associada à evaporação do orvalho acumulado. Mesmo deslocando-se até o local do experimento, a camada de orvalho permaneceu sobre o veículo. $\mathrm{O}$ sensor foi instalado ainda sobre a película de água.

Início: $07 \mathrm{~h} 00 \mathrm{~m}$

Fim: 12 h $00 \mathrm{~m}$
Local: Rua Sebastião Cortês, bairro de Perdizes, início e fim na Rua Campevas, próximo à Avenida Sumaré. 


\begin{tabular}{|c|c|}
\hline EFX-4 26/08/2007 & $\begin{array}{l}\text { Súmula Meteorológica: ensolarado desde o início } \\
\text { da manhã. Situação pré-frontal. Vento calmo, com } \\
\text { ocorrência de episódios de brisa. Ar seco e } \\
\text { poluído. }\end{array}$ \\
\hline \multicolumn{2}{|l|}{ Observações } \\
\hline \multicolumn{2}{|c|}{$\begin{array}{l}\text { (1) Foram feitas mensurações nas seguintes superfícies, na ordem do arquivo de dados: árvore, } \\
\text { parede, asfalto e ar. Os canais } 01,02,03 \text { e } 04 \text { registraram as superfícies expostas ao céu. Os } \\
\text { canais } 08,09,10,11 \text { registraram as superfícies abaixo das copas das árvores. O registro } 15 \\
\text { corresponde à temperatura do micrologger usada como referência. }\end{array}$} \\
\hline \multicolumn{2}{|c|}{$\begin{array}{l}\text { (2) A parede exposta ao céu, e que foi monitorada, passou a ficar sob a sombra no decorrer do } \\
\text { experimento. Vale notar que a face oposta da parede passou a ficar ensolarada na parte final da } \\
\text { manhã. }\end{array}$} \\
\hline \multicolumn{2}{|c|}{$\begin{array}{l}\text { (3) A área de estudo ainda esteve sob domínio de muitas sombras (prédios e árvores), devido } \\
\text { ainda à elevada declinação solar. Porém, nesta época o Sol declina rapidamente e já foi possível } \\
\text { verificar alterações no posicionamento das sombras. }\end{array}$} \\
\hline \multicolumn{2}{|c|}{$\begin{array}{l}\text { (4) O asfalto exposto e que foi monitorado, ficou sob incidência direta dos raios solares desde o } \\
\text { início da manhã. Na etapa final houve sombra de algumas folhas de uma pequena copa. }\end{array}$} \\
\hline \multicolumn{2}{|c|}{$\begin{array}{l}\text { (5) Aparentemente houve outro mínimo na temperatura do ar, desta vez das medições próximas ao } \\
\text { asfalto, algo entre } 13 \text { e } 14 \text { graus. A explicação pode estar associada novamente ao fluxo } \\
\text { convectivo, mas desta vez na forma de calor sensível. O ar sobre o asfalto aquecido eleva-se, } \\
\text { dando lugar ao ar mais frio que ainda está escoando dos setores da cidade e do interior dos } \\
\text { prédios que ainda não foram iluminados suficientemente. Como a temperatura do ar sob a sombra } \\
\text { das árvores e em um nível mais elevado é maior, parece ocorrer um efeito de inversão térmica } \\
\text { nesta camada sob a copa das árvores e que estende-se para além delas sobre a superfície, com } \\
\text { uma forte instabilidade sobre os primeiros centímetros. }\end{array}$} \\
\hline $\begin{array}{l}\text { Início: } 08 \text { h } 09 \text { m } \\
\text { Fim: } 12 \text { h } 56 \text { m }\end{array}$ & $\begin{array}{l}\text { Local: Rua Sebastião Cortês, bairro de Perdizes, } \\
\text { início e fim na Rua Campevas, próximo à Avenida } \\
\text { Sumaré. }\end{array}$ \\
\hline
\end{tabular}




\begin{tabular}{|c|c|}
\hline EFG-1 31/03/2007 & $\begin{array}{l}\text { Súmula Meteorológica: ensolarado com muitas } \\
\text { nuvens cumulus. Passando a nublado com } \\
\text { cumulo-nimbus e início de chuva. Situação pré- } \\
\text { frontal com vento fraco e algumas rajadas. }\end{array}$ \\
\hline \multicolumn{2}{|l|}{ Observações } \\
\hline \multicolumn{2}{|c|}{$\begin{array}{l}\text { (1) O horário das fotos foi semelhante ao horário dos experimentos anteriores nestas duas } \\
\text { localidades. }\end{array}$} \\
\hline \multicolumn{2}{|c|}{$\begin{array}{l}\text { (2) A condição de tempo foi muito semelhante à observada no dia do experimento na rua } \\
\text { Sebastião Cortês. Ligeiramente mais ensolarado no horário das fotos. Em relação ao dia do } \\
\text { experimento na Avenida Pompéia, o dia esteve mais nublado. }\end{array}$} \\
\hline $\begin{array}{l}\text { Início: } 14 \text { h } 00 \text { m } \\
\text { Fim: } 16 \text { h } 00 \text { m }\end{array}$ & Local: Rua Sebastião Cortês e Avenida Pompéia. \\
\hline
\end{tabular}

\begin{tabular}{|c|c|}
\hline EFG-2 07/07/2007 & $\begin{array}{l}\text { Súmula Meteorológica: ensolarado. Ar poluído, } \\
\text { após uma semana de domínio da alta pressão. } \\
\text { Situação pré-frontal, sem vento. }\end{array}$ \\
\hline \multicolumn{2}{|l|}{ Obser } \\
\hline \multicolumn{2}{|c|}{ (1) Problemas com seguranças particulares, que questionavam as fotos. } \\
\hline \multicolumn{2}{|c|}{$\begin{array}{l}\text { (2) As três avenidas partem da Marginal Pinheiros e chegam aos bairros Alto de Pinheiros e Alto da } \\
\text { Lapa, onde fica a praça fotografada. As três avenidas são aproximadamente paralelas, e durante } \\
\text { os experimentos são percorridas no sentido sudoeste-nordeste. }\end{array}$} \\
\hline \multicolumn{2}{|c|}{$\begin{array}{l}\text { (3) A seqüência das fotos foi: Queiroz Filho (entre } 09.30 \text { e } 10.00 \mathrm{~h} \text { ), Praça John Lennon (entre } \\
10.00 \text { e } 10.30 \mathrm{~h} \text { ), Prof. Frederico Hermann Júnior (entre } 10.30 \text { e } 11.00 \mathrm{~h} \text { ) e dos Semaneiros (entre } \\
11.00 \text { e } 11.30 \text { h). }\end{array}$} \\
\hline \multicolumn{2}{|c|}{ (4) Manhã de sábado de um feriado prolongado. } \\
\hline $\begin{array}{l}\text { Início: } 09 \text { h } 30 \text { m } \\
\text { Fim: } 11 \text { h } 30 \text { m }\end{array}$ & $\begin{array}{l}\text { Local: Avenida Queiroz Filho (cemitério da Lapa), } \\
\text { Praça John Lennon (City Lapa), Avenida Prof. } \\
\text { Frederico Hermann Júnior (CETESB) e Avenida } \\
\text { dos Semaneiros (esquina com a Praça Pôr do } \\
\text { Sol). }\end{array}$ \\
\hline
\end{tabular}




\begin{tabular}{|c|c|}
\hline EFG-3 27/08/2007 & $\begin{array}{l}\text { Súmula Meteorológica: sol com muitas nuvens } \\
\text { (alto stratus e alto cumulus) e névoa expensa } \\
\text { reduzindo consideravelmente a visibilidade. Ar } \\
\text { seco e poluído, após algumas semanas de } \\
\text { domínio da alta pressão do Atlântico. Situação pré- } \\
\text { frontal, vento fraco. }\end{array}$ \\
\hline \multirow{3}{*}{\multicolumn{2}{|c|}{$\begin{array}{l}\text { Observações } \\
\text { (1) Em geral áreas comerciais e públicas sem qualquer questionamento ou problemas com } \\
\text { seguranças particulares. } \\
\text { (2) Trata-se de três eixos zonais praticamente paralelos. O mais interno representado pela Rua } \\
\text { Tito, na vertente sul da bacia do Tietê. O intermediário representado pelo eixo da Avenida Marquês } \\
\text { de São Vicente, já após a linha férrea. E o mais externo, em relação ao divisor de águas das } \\
\text { bacias do Pinheiros e Tietê, representado pela Marginal Tietê, já no fundo do vale. } \\
\text { (3) A seqüência das fotos foi: Tito (entre } 11 \text { e } 11.10 \mathrm{~h} \text { ), Marquês (entre } 11.30 \text { e } 11.40 \mathrm{~h} \text { ), Norma } \\
\text { (entre } 11.50 \text { e } 12.00 \mathrm{~h} \text { ), Marquês (entre } 12.10 \text { e } 12.20 \mathrm{~h} \text { ), Marginal Tietê externa (12.30 e } 12.40 \mathrm{~h} \text { ) } \\
\text { e Marginal Tietê interna (entre } 12.50 \text { e } 13.00 \mathrm{~h} \text { ). }\end{array}$}} \\
\hline & \\
\hline & \\
\hline \multicolumn{2}{|c|}{ (4) Manhã de segunda-feira, dia útil comum. } \\
\hline $\begin{array}{l}\text { Início: } 11 \text { h } 00 \text { m } \\
\text { Fim: } 13 \text { h } 00 \text { m }\end{array}$ & $\begin{array}{l}\text { Local: Rua Tito (primeiros quarteirões após a Pio } \\
\text { XI e antes da Rua Toneleiros), Avenida Marquês } \\
\text { de São Vicente (inicialmente no sentido centro } \\
\text { após o Tribunal do Trabalho na esquina com a Av. } \\
\text { Pacaembu, posteriormente no sentido bairro, na } \\
\text { esquina com a Av. Pompéia), Avenida Norma } \\
\text { Pieruccini Giannotti (continuação da Marquês, } \\
\text { inicialmente a um quarteirão da esquina com a Av. } \\
\text { Rudge, posteriormente a um quarteirão e meio da } \\
\text { Av. Rudge), Marginal Tietê via externa } \\
\text { (inicialmente no sentido Leste entre a Ponte da } \\
\text { Freguesia e a Ponte Júlio de Mesquita, } \\
\text { posteriormente no sentido Oeste entre a Ponte } \\
\text { Júlio de Mesquita e a Ponte da Freguesia) e } \\
\text { Marginal Tietê via interna (inicialmente no sentido } \\
\text { Leste entre a Ponte do Piqueri e a Ponte da } \\
\text { Freguesia, posteriormente no sentido Oeste entre } \\
\text { a Ponte da Freguesia e a Ponte do Piqueri). }\end{array}$ \\
\hline
\end{tabular}




\begin{tabular}{|c|c|}
\hline EFG-4 03/09/2007 & $\begin{array}{l}\text { Súmula Meteorológica: sol com muitas nuvens } \\
\text { (cumulus congestus e nimbus), passando a } \\
\text { nublado com chuva (trovoadas). Névoa seca pela } \\
\text { manhã, com visibilidade reduzida. } \\
\text { Desenvolvimento convectivo no início da tarde. } \\
\text { Situação pós-frontal, vento fraco a moderado. }\end{array}$ \\
\hline \multicolumn{2}{|l|}{ Observacões } \\
\hline \multicolumn{2}{|c|}{$\begin{array}{l}\text { (1) Área mista, comercial e residencial. Novamente problemas com propriedades particulares, os } \\
\text { proprietários residenciais em geral questionam as fotos. }\end{array}$} \\
\hline \multicolumn{2}{|c|}{$\begin{array}{l}\text { (2) Trata-se de dois eixos paralelos (Diógenes e Pio XI) na vertente do Pinheiros (um próximo ao } \\
\text { vale e o outro próximo ao divisor, respectivamente), cortados pelo eixo da Dardanelos } \\
\text { (perpendicular ao vale e ao divisor de águas). }\end{array}$} \\
\hline \multicolumn{2}{|c|}{$\begin{array}{l}\text { (3) A seqüência das fotos foi: Pio XI (entre } 13.30 \text { e } 13.45 \text { h), Dardanelos (entre } 13.50 \text { e } 14.00 \text { h), } \\
\text { Diógenes (entre } 14.05 \text { e } 14.20 \text { h) e Dardanelos (entre } 14.25 \text { e } 14.30 \mathrm{~h} \text { ). }\end{array}$} \\
\hline \multicolumn{2}{|c|}{$\begin{array}{l}\text { (4) Início de uma tarde de segunda-feira, dia útil de uma semana com feriado prolongado a partir } \\
\text { da sexta-feira seguinte. }\end{array}$} \\
\hline $\begin{array}{l}\text { Início: } 13 \text { h } 30 \text { m } \\
\text { Fim: } 14 \text { h } 30 \text { m }\end{array}$ & $\begin{array}{l}\text { Local: Rua Pio XI (inicialmente subindo, } \\
\text { posteriormente descendo, em torno da esquina } \\
\text { com a Rua Caiapônia), Rua Dardanelos } \\
\text { (inicialmente subindo, posteriormente descendo, } \\
\text { em torno da esquina com a Rua Antonio Alarcon), } \\
\text { e Avenida Diógenes Ribeiro de Lima (inicialmente } \\
\text { no sentido bairro logo após à esquina com a Rua } \\
\text { Majubim, posteriormente no sentido centro na } \\
\text { quadra seguinte à Rua Barlioz). }\end{array}$ \\
\hline
\end{tabular}




\section{Referências}

ALMEIDA, L. T., ASSUNÇÃO, J. V. and ESTON, S. M., 2002, Characteristics of suspended particulate matter in a University Campus area in São Paulo, Brazil. In: Proceedings Global Conference, São Paulo.

ARAÚJO, R. A., 2005, Esboço inicial da climatologia na geografia da Faculdade de Filosofia, Letras e Ciências Humanas da Universidade de São Paulo. Dissertação de Mestrado. Departamento de Geografia da Universidade de São Paulo.

ARISTÓTELES, o Estagirita (séc. IV a.C.), 1996, Los Meteorológicos. Introdução, tradução e notas de José Luis Calvo Martinez. Madrid, Alianza Editorial S. A.

ARNFIELD, A. J., 1982, An approach to the estimation of the surface radiative properties and radiation budgets of cities. Physical Geography, 3, p. $97-122$.

ARYA, S. P., 2001, Introduction to Micrometeorology. International Geophysics Series, vol.79. San Diego, Academic Press, 420 p.

ATTIE, M., 2002, Falsafa, a filosofia entre os árabes. São Paulo, Editora Palas Athena.

AZEVEDO, T. R., 2001, Derivação antrópica do clima na Região Metropolitana de São Paulo (RMSP) abordada como função do ritmo semanal das atividades humanas. Tese de Doutorado, FFLCH - USP.

AZEVEDO, T. R., 2002a, Ritmo semanal do campo de vento na Grande São Paulo. In: Anais do V Simpósio de Climatologia Geográfica. Curitiba, UFPR, 4 a 6 de dezembro.

AZEVEDO, T. R., 2002b, Chove todo dia em São Paulo?. In: XII Encontro Nacional de Geógrafos. João Pessoa, UFPB, 21 a 26 de julho, AGB. 
AZEVEDO, T. R., 2003, O ritmo da atividade urbana e a concentração de ozônio na camada de mistura na região metropolitana de São Paulo e arredores. In: $X$ Simpósio Brasileiro de Geografia Física Aplicada, v. 1. Rio de Janeiro, UFRJ.

AZEVEDO, T. R., 2004, A frota de automóveis e o pó que São Paulo respira - particulado inalável no clima da cidade. In: Ana Fani Alessandri Carlos, Ariovaldo Umbelino de Oliveira (Org.). Geografias de São Paulo. 1 ed. São Paulo, Contexto, v. 1, p. 7388.

AZEVEDO, T. R. e TARIFA, J. R., 2002, Estudo comparativo do desempenho de miniregistradores digitais de temperatura e umidade do ar em abrigo meteorológico padrão e no mini-abrigo meteorológico aspirado. GEOUSP - Espaço e Tempo, 11, p. $129-142$.

BARRING, L., 1985, Canyon geometry, street temperatures and urban heat island in Malmo, Sweden. Journal of Climatology, 5, p. 433 - 444.

BATTLES, F. J., OLMO, F. J., TOVAR, J. and ALADOS-ARBOLEDAS, L., 2000, Comparison of cloudless sky parameterizations of solar iradiance at various Spanish midlatitude locations. Theoretical and Applied Climatology, 66, p. 81 - 93.

BOLTON, D., 1980, The computation of equivalent potential temperature. Monthly Weather Review, 108, p. 1046-1053.

BRADLEY, R. S., 1999, Paleoclimatology - reconstructing Climates of the Quaternary. International Geophysics Series, vol. 68. Amsterdan, Elsevier, $2^{\text {nd }}$ ed.

BREST, C. L., 1987, Seasonal albedo of an urban / rural landscape from satellite observations. Journal of Climate and Applied Meteorology, 26, p. 1169 - 1187.

CAMPBELL, J., 2001, O poder do mito. São Paulo, Editora Palas Athena. $19^{a}$ edição. 
CASELlES, V., SOBRINO, J. A. and BECKER, F., 1988, Determination of the effective emissivity and temperature under vertical observation of a citrus orchard. Application to frost nowcasting. International Journal of Remote Sensing, 9, p. 715 $-727$.

CHAUÍ, M., 2005, Natureza, cultura, patrimônio ambiental. In: Meio ambiente: patrimônio cultural da USP. São Paulo, Edusp, p. 47 - 55.

CLAVAL, P., 1981, La logique des villes. Paris, Litec Librairies Techniques.

CRAWFORD, T. M. and DUCHON, C. E, 1999, An improved parameterization for estimating atmospheric emissivity for use in calculating daytime downwelling longwave radiation. Journal of Applied Meteorology, 38, p. 474 - 480.

De ROOY, W. C. and HOLTSLAG, A. A. M., 1999, Estimation of surface radiation and energy flux densities from single - level weather data. Journal of Applied Meteorology, 38, p. $526-540$.

DUBOIS, P., 1929, Nächtliche effektive Ausstrahlung. Gerl. B., 22, p. 41 - 99.

DUCHON, C. E. and WILK, G. E., 1994, Field comparisons of direct and component measurements of net radiation under clear skies. Journal of Applied Meteorology, 33 , p. $245-251$.

FAIRALl, C. W., PERSSON, P. O. G., BRADLEY, E. F., PAYNE, R. E. and ANDERSON, S. P., 1998, A new look at calibration and use of Eppley precision infrared radiometers. Part I: theory and application. Journal of Atmospheric and Oceanic Technology, 15, p. $1229-1242$.

FRANÇA, A., 1946, Estudo sobre o clima da bacia de São Paulo. Boletim $n^{o} L X X$ da Faculdade de Filosofia, Letras e Ciências Humanas da Universidade de São Paulo. 
FRANÇA, A., 1958, O quadro climato - botânico. In: A cidade de São Paulo - estudos de geografia urbana. Aroldo de Azevedo (Org.), vol. I. AGB São Paulo, Companhia Editora Nacional.

GEIGER, R., 1950, The climate near the ground. Cambridge, Harvard University Press.

GEIGER, R., ARON, R. H. and TODHUNTER, P., 2003, The Climate near the ground. Lanham, Rowman \& Littlefield Publishers, Inc., $6^{\text {a }}$ ed.

GOETHE, Johann Wolfgang von (1810), 1998, Die Wahlverwandtschaften. Tradução Erlon José Paschoal, a partir da $2^{\mathrm{a}}$ edição. Prefácio e notas Kathrin Holzermayr Rosenfield. São Paulo, Editora Nova Alexandria.

GOMBRICH, E. H., 1999, A história da arte. Rio de Janeiro, LTC - Livros Técnicos e Científicos Editora S.A. 16a edição.

GRIMMOND, C. S. B., 1992, The suburban energy balance: methodological considerations and results for a mid-latitude west cost city under winter and spring conditions. International Journal of Climatology, 12, p. 481 - 497.

GRIMMOND, C. S. B., SALMOND, J. A., OKE, T. R., OFFERLE, B. and LEMONSU, A., 2004, Flux and turbulence measurements at a dense urban site in Marseille: heat, mass (water, carbon dioxide) and momentum. Journal of Geophysical Research-Atmospheres, 109, D24101, p. 1 - 19.

GRIMMOND, C. S. B. and OKE, T. R., 1991, An evaporation-interception model for urban areas. Water Resources Research, 27, p. 1739-1755.

GRIMMOND, C. S. B. and OKE, T. R., 1995, Comparison of Heat Fluxes from Summertime Observations in the Suburbs of Four North American Cities. Journal of Applied Meteorology, 34, p. 873 - 889. 
GRIMMOND, C. S. B. and OKE, T. R., 1999, Aerodynamic properties of urban areas derived from analysis of surface form. Journal of Applied Meteorology, 38, p.12621292.

GRIMMOND, C. S. B. and OKE, T. R., 2002, Turbulent heat fluxes in urban areas: observations and a Local-scale Urban Meteorological Parameterization Scheme (LUMPS). Journal of Applied Meteorology, 41, p. 792-810.

GRIMMOND, C. S. B., OKE, T. R., SOUCH, C. and HUBBLE, M. D., 1996, Influence of tree cover on summertime surface energy balance fluxes, San Grabiel Valley, Los Angeles. Climate Research, 6, p. $45-57$.

HARTMANN, D. L., 1994, Global Physical Climatology. International Geophysics Series, vol. 56. San Diego, Academic Press, $1^{\text {st }}$ ed.

HODGES, E. B. and SMITH, E. A., 1997, Intercalibration, objective analysis, intercomparison, and synthesis of BOREAS surface net radiation measurements. Journal of Geophysical Research, 102, p. 28885 - 28900.

HOLTON, J. R., 2004, An Introduction to Dynamic Meteorology. International Geophysics Series, vol. 88. Amsterdan, Elsevier, $4^{\text {th }}$ ed.

HOLTSlAG, A. A. M. and van ULDEN, A. P., 1983, A simple scheme for daytime estimates of the surface fluxes from routine weather data. Journal of Climate and Applied Meteorology, 22, p. 517 - 529.

HU, Z., ISLAM, S. and JIANG, L., 1999, Approaches for aggregating heterogeneous surface parameters and fluxes for mesoescale and climate models. Boundary-Layer Meteorology, 93, p. 313 - 336.

IDSO, S. B. e JACKSON, R. D., 1969, Thermal radiation from the atmosphere. Journal of Geophysical Research, 74, p. 5397 - 5403. 
INPE (Instituto Nacional de Pesquisas Espaciais), 1999, Tutorial do SPRING (Sistema de Processamento de Informações Georreferenciadas) - geoprocessamento ao alcance de todos. São José dos Campos, SP, Brasil.

IZIOMON, M. G., MAYER, H. and MATZARAKIS, A., 2003, Downward atmospheric longwave irradiance under clear and cloudy skies: measurement and parameterization. Journal of Atmospheric and Solar-Terrestrial Physics, 65, p.1107 $-1116$.

JOHNSON, G. T., OKE, T. R., LYONS, T. J., STEYN, D. G., WATSON, I. D. and VOOGT, J. A., 1991, Simulation of surface urban heat islands under 'ideal' conditions at night, Part 1: Theory and tests against field data. Boundary-Layer Meteorology, 56, p. 275-294.

KAIMAL, J. C. and FINNIGAN, J. J., 1994, Atmospheric boundary layer flows: their structure and measurement. New York, Oxford University Press.

KIPP \& ZONEN, 2001, Instruction manual CNR1 net-radiometer.

KOTLER, P., 2000, Administração de marketing. São Paulo, Editora Prentice Hall, $10^{\mathrm{a} e d i c ̧ a ̃ o . ~}$

KRETZSCHMAR, J. G., 1994, Particulate matter levels and trends in Mexico city, São Paulo, Buenos Aires and Rio de Janeiro. Atmospheric Environment, 28, $\mathrm{n}^{\mathbf{o}}$ 19, p.3181 - 3191 .

LANDSBERG, H. E., 1981, The urban climate. New York, Academic Press.

LANDSBERG, H. E., 2006, The climate of towns. Revista do Departamento de Geografia, Universidade de São Paulo, vol. 18, p. 95 - 111.

LATIMER, J. R., 1972, Radiation measurement. Ottawa, International Field Year for the Great Lakes Technical Manual, Ser. 2, NRC / USNAS / IHD. 
LI-COR, 1991, LI-COR - Terrestrial Radiation Sensor, Type SZ. Manual de instruções.

LINACRE, E., 1992, Climate data and resources - a reference and guide. London, Routledge, Chapman and Hall, Inc., $1^{\text {a }}$ ed.

LIOU, K. N., 2002, An Introduction to Atmospheric Radiation. International Geophysics Series, vol. 84. San Diego, Academic Press, $2^{\text {nd }}$ ed.

LLOYD, J., 2007, Weather. Bath, Parragon, $1^{\text {st }}$ ed.

LOMBARDO, M. A., 1985, Ilha de calor nas metrópoles, o exemplo de São Paulo. São Paulo, Editora Hucitec.

LOWRY, W. P., 1977, Empirical estimation of urban effects on climate: a problem analysis. Journal of Applied Meteorology, vol. 16, p. 129 - 135.

MACHADO, A. J., 1993, As circulações locais associadas à formação de nevoeiro na Grande São Paulo. Dissertação de mestrado, IAG - USP.

MACHADO, A. J. e AZEVEDO, T. R. de, 2004, Observações não convencionais da radiação atmosférica na CUASO e imediações. In: II Seminário de Pesquisa em Geografia Física - SEPEGE, 11 e 12 de dezembro, São Paulo, p. 657 - 662 (CDROM).

MACHADO, A. J. e AZEVEDO, T. R. de, 2005, Fluxo diurno de radiação de onda longa recebida em um trajeto urbano arborizado. In: XI Simpósio Brasileiro de Geografia Física Aplicada - Geografia, Tecnociência, Sociedade e Natureza. São Paulo, p.100-109 (CDROM).

MACHADO, A. J. e AZEVEDO, T. R. de, 2006a, Da necessidade de correção das medidas de radiação térmica obtida através de plataformas móveis em áreas urbanas. In: III Seminário de Pesquisa em Geografia Física - SEPEGE - Contribuição da pesquisa 
em Geografia Física, 11 e 12 de dezembro, São Paulo, Programa de Pós-graduação em Geografia Física da Universidade de São Paulo, p. 37 - 48 (CDROM).

MACHADO, A. J. e AZEVEDO, T. R. de, 2006b, A distribuição espacial dos termos do balanço de energia em superfície a partir de imagem orbital e observação de campo. In: Revista do Departamento de Geografia, vol. 19, p. 81 - 91, São Paulo, Universidade de São Paulo.

MACHADO, A. J. and AZEVEDO, T. R. de, 2007a, Detection of the urban heat-island effect from a surface mobile platform. In: Revista de Teledetcción, vol. 27, p. 59 70, Valladolid, Agéncia Española de Teledetección.

MACHADO, A. J. e AZEVEDO, T. R. de, 2007b, Parâmetros meteorológicos observados na rede telemétrica da CETESB. In: Anais do I Workshop Regional de Geografia e Mudanças Ambientais, desafios da sociedade do presente e do futuro, Guarapuava, Universidade Estadual do Centro-Oeste Paranaense, p. 23 - 32.

MARTINS, E. R., 2007, Geografia e ontologia: o fundamento geográfico do ser. In: GEOUSP-Espaço e Tempo, $\mathrm{n}^{\circ}$ 21, São Paulo, Departamento de Geografia da Universidade de São Paulo, p. 33 - 51.

MARX, M., 1991, Cidade no Brasil, terra de quem? São Paulo, Editora Nobel.

MASSON, V., GRIMMOND, C. S. B. and OKE, T. R., 2002, Evaluation of the Town Energy Balance (TEB) scheme with direct measurements from dry districts in two cities. Journal of Applied Meteorology, 41, p. 1011-1026.

MONTEIRO, C. A. F., 1975, Teoria e Clima Urbano. Tese de livre-docência apresentada à Faculdade de Filosofia, Letras e Ciências Humanas da Universidade de São Paulo.

MONTEIRO, C. A. F., 1981, A questão ambiental no Brasil, 1960 - 1980. São Paulo, Instituto Geográfico, Universidade de São Paulo. 
MORAES, A. C. R., 2002, Geografia: pequena história crítica. São Paulo, Editora Hucitec.

NAKAMURA, Y. and OKE, T. R., 1988, Wind, temperature and stability conditions in na E - W oriented urban canyon. Atmospheric Environment, 22, p. 2691 - 2700.

NAPPO, C. J., 2002, An Introduction to Atmospheric Gravity Waves. International Geophysics Series, vol. 85. San Diego, Academic Press, $1^{\text {st }}$ ed.

NEWTON, T., 1999, Energy balance fluxes in a subtropical city: Miami, FL. M.Sc. thesis, Dept. of Geography, University of British Columbia, Vancouver, BC, Canada.

NIEMELÄ, S. P., RÄSÄNEN, P. and SAVIJÄRVI, H., 2001, Comparison of surface radiative flux parameterizations. Part I: Longwave radiation. Atmospheric Research, 58, p. 01-18.

NUNEZ, M. and OKE, T. R., 1977, The energy balance of an urban canyon. Journal of Applied Meteorology, 16, p. 11 - 19.

OFFERLE, B., GRIMMOND, C. S. B. and OKE, T. R., 2003, Parameterization of net allwave radiation for urban areas. Journal of Applied Meteorology, 42, p. 1157-1173.

OFFERLE, B., GRIMMOND, C. S. B., FORTUNIAK, K., KLYSIK, K. and OKE, T. R., 2006, Temporal variations in heat fluxes over a northern European city centre. Theoretical and Applied Climatology, 84, p. 103 - 115.

OKE, T.R., 1981, Canyon geometry and the nocturnal urban heat island: comparison of scale model and field observations. Journal of Climatology, 1, p. 237 - 254.

OKE, T.R., 1987, Boundary Layer Climates. London, Routledge, $2^{\mathrm{a}}$ ed.

OKE, T.R., 1988, The urban energy balance. Progress in Physical Geography, 12, p. 471 508. 
OKE, T.R., 1989, The micrometeorology of the urban forest. Philosophical Transactions of the Royal Society of London, Series B, 324, p. 335 - 351.

OKE, T.R., 1995, Classics in physical geography - Climatological studies in Uppsala. Progress in Physical Geography, 19, p. 107-113.

OKE, T.R., 1998, An algorithmic scheme to estimate hourly heat island magnitude. Second Urban Environment Symposium, Boston, MA, American Meteorological Society, p. $80-83$.

OKE, T.R., 2004, Initial guidance to obtain representative meteorological observations at urban sites. Instruments and methods of observation program, n. 81, WMO/TD 1250, Geneva, World Meteorological Organization.

OKE, T.R., 2006, Towards better scientific communication in urban climate. Theoretical and Applied Climatology, 84, p. 179-190.

OKE, T.R., CLEUGH, H. A., GRIMMOND, C. S. B., SCHMID, H. P. and ROTH, M., 1989, Evaluation of spatially-averaged fluxes of heat, mass and momentum in the urban boundary layer. Weather and Climate, 9, p. 14-21.

OKE, T.R., JOHNSON, G. T., STEYN, D. G. and WATSON, I. D., 1991, Simulation of nocturnal surface urban heat islands under "ideal" conditions: Part 2. Diagnosis of causation. Boundary-Layer Meteorology, 56, p. 339-358.

OKE, T.R., SPRONKEN-SMITH, R., JAURÉGUI, E. and GRIMMOND, C. S. B., 1999, The energy balance of central Mexico City during the dry season. Atmospheric Environment, 33, p. 3919-3930.

OLIVEIRA, A. P., MACHADO, A. J., ESCOBEDO, J. F. and SOARES, J., 2002a, Diurnal evolution of solar radiation at the surface in the city of São Paulo: seasonal variation and modelling. Theoretical and Applied Climatology, 71, p. 231 - 250. 
OLIVEIRA, A. P., ESCOBEDO, J. F. and MACHADO, A. J., 2002b, A new shadow-ring device for measuring diffuse solar radiation at the surface. Journal of Atmospheric and Oceanic Technology, 19, p. 698 - 708.

OLIVEIRA, A. P., SOARES, J., ESCOBEDO, J. F., MACHADO, A. J., CODATO, G. and GALVANI, E., 2002c, Diurnal evolution of surface radiation budget components in the cities of São Paulo and Botucatu. Anais do IX Congresso Brasileiro de Engenharia e Ciências Térmicas, 15 a 18 de outubro, Caxambu, MG (CDROM).

ONCLEY, S. P. and co-authors, 2002, The energy balance experiment EBEX-2000. 25 $5^{\text {th }}$ Conference on Agricultural and Forest Meteorology, Norfolk, VA, American Meteorological Society, p. 1 - 2.

ORLANSKI, I., 1976, A simple boundary condition for unbounded hyperbolic flows. Journal of Computational Physics, 21, p. 251 - 269.

PEREIRA LEITE, M. A. F., 2005, Patrimônio ambiental: a memória social e sua continuidade. In: Meio ambiente e patrimônio cultural da USP. São Paulo, CPC/USP, EDUSP, p. 41 - 46.

PIELKE, RA., 2002, Mesoscale Meteorological Modeling. San Diego, Academic Press, $2^{\text {nd }}$ ed.

PRATA, A. J., 1996, A new long-wave formula for estimating downward clear-sky radiations at the surface. Quarterly Journal of the Royal Meteorological Society, 122, p. $1127-1151$.

RIBEIRO, H. e AZEVEDO, T. R. de, 2005, O patrimônio em áreas verdes da USP e a atmosfera urbana. In: Meio ambiente e patrimônio cultural da USP. São Paulo, CPC/USP, EDUSP, p. 19 - 40. 
RICHARDS, K. and OKE, T. R., 2002, Validation and results os a scale model of dew deposition in urban environments. International Journal of Climatology, 22, p.1915-1933.

ROGERS, R. e GUMUCHDJIAN, P., 2001, Cidades para um pequeno planeta. Barcelona, Editorial Gustavo Gili, SA, edição portuguesa.

ROSS, S. L. and OKE, T. R., 1988, Tests of three urban energy balance models. Boundary - Layer Meteorology, 44, p. 73 - 96.

ROTH, M. and OKE, T. R., 1995, Relative efficiencies of turbulent transfer of heat, mass and momentum over a patchy urban surface. Journal of the Atmospheric Sciences, $52,1863-1874$.

ROTH, M., OKE, T. R. and EMERY, W. J., 1989, Satellite - derived urban heat islands from three coastal cities and the utility of such data in urban climatology. International Journal of Remote Sensing, 10, p. 1699 - 1720.

RUNNALLS, K. E. and OKE, T. R., 2000, Dynamics and controls of the near-surface heat island of Vancouver, BC. Physical Geography, 21, p. 283-304.

SALVI-SAKAMOTO, L. L., 2001, Os Micro climas e a "Configuração do Céu" na Área Central. Os Climas na Cidade de São Paulo, Teoria e Prática. GEOUSP 4, p. 165 187.

SCHMID, H. P., CLEUGH, H. A., GRIMMOND, C. S. B. and OKE, T. R., 1991, Spatial variability of energy fluxes in suburban terrain. Boundary-Layer Meteorology, 54, p. 249-276.

SCHMID, H. P., GRIMMOND, C. S. B., CROPLEY, F., OFFERLE, B. and SU, H. B., 2000, Measurements of $\mathrm{CO}_{2}$ and energy fluxes over a mixed hardwood forest in the mid-western United States. Agricultural and Forest Meteorology, 103, p.357 - 374. 
SCHOTANUS, P., NIEUWSTADT, F. T. M. and De BRUIN, H. A. R., 1983, Temperature measurement with a sonic anemometer and its application to heat and moisture fluctuations. Boundary Layer Meteorology, 26, p. 81 - 93.

SELLERS, W. D., 1965, Physical Climatology. The University of Chicago Press.

SILVA DIAS, M. A. F. and MACHADO, A. J., 1997, The role of local circulations in summertime convective development and nocturnal fog in São Paulo, Brazil. Boundary-Layer Meteorology, 82, p. 135 - 157.

SMITH, W. L., 1966, Note on the relation between total precipitable water and surface dew point. Journal of Applied Meteorology, 5, p. 726 - 727.

SOJA, E. W. 1993, Geografias pós-modernas. Tradução da $2^{\mathrm{a}}$ edição inglesa. Rio de Janeiro, Jorge Zahar Editor.

SORRE, M., 1934, Traité de Climatologie Biologique et Médicale. Paris, M. Piery Nasson et Cie. Éditeurs, p. 1 - 9.

SORRE, M., 2006, Object and method of climatology. Revista do Departamento de Geografia, Universidade de São Paulo, vol. 18, p. 89 - 94.

SOTTSASS, E., 1991, On the nature of metropolises. Terrazzo, Architecture and Design 6, p. $38-40$.

SOUX, A., 2000, Modelling surface structure and temperature of relevance to remote sensing of cities. M.Sc. Dissertation, Geography, University of British Columbia, Vancouver, BC.

SOUX, A., VOOGT, J. A. and OKE, T. R., 2004, A model to calculate what a remote sensor 'sees' of an urban surface. Boundary-Layer Meteorology, 112, p. 401 - 424.

SOUZA, M. A. A., 1994, A identidade da metrópole. São Paulo, EDUSP. 
SOZZI, R., SALCIDO, A., SALDAÑA FLORES, R. and GEORGIADIS, T., 1999, Daytime net radiation parameterization for México City suburban areas. Atmospheric Research, 50, p. 53 - 68.

SPIRN, A. W., 1995, O jardim de granito: a natureza no desenho da cidade. São Paulo, EDUSP.

SPRONKEN-SMITH, R.A. and OKE, T. R., 1999, Scale modelling of nocturnal cooling in urban parks. Boundary-Layer Meteorology, 93, p. 287 - 312.

SPRONKEN-SMITH, R.A., OKE, T. R. and LOWRY, W. P., 2000, Advection and the surface energy balance of an irrigated urban park. International Journal of Climatology, 20, p. 1033 - 1047.

STULL, R. B., 1988, An Introduction to Boundary Layer Meteorology. Dordrecht, Kluwer Academic Publishers.

SUGITA, M. and BRUTSAERT, W., 1993, Cloud effect in the estimation of instantaneous downward long wave radiation. Water Resources Research, 29, p. 599 - 605.

SUTHERLAND, R. A. and BARTHOLIC, J. F., 1977, Significance of vegetation in interpreting thermal radiation from a terrestrial surface. Journal of Applied Meteorology, 16, p. $759-763$.

TARIFA, J. R., 1976, Sobre um Programa de "Climatologia Experimental" na Região Metropolitana de São Paulo. Boletim Paulista de Geografia, 52, São Paulo, Associação dos Geógrafos Brasileiros, p. 101 - 119.

TARIFA, J. R., 1999, O Clima do (no) Campo. GEOUSP, 6, p. 107 - 114.

TARIFA, J. R. e ARMANI, G., 2001, Os Climas Urbanos. Os Climas na Cidade de São Paulo, Teoria e Prática. GEOUSP, 4, p. 47 - 70. 
THORSSON, S. and ELIASSON, I., 2003, An intra-urban thermal breeze in Göteborg, Sweden. Theoretical and Applied Climatology, 75, p. 93 - 104.

UNSWORTH, M.H. and MONTEITH, J. L., 1975, Geometry of long-wave radiation at the ground I - angular distribution of incoming radiation at the ground. Quarterly Journal of the Royal Meteorological Society, 101, p. 13-24.

Van ULDEN, A. P. and HOLTSlAG, A. A. M., 1985, Estimation of atmospheric boundary layer parameters for diffusion applications. Journal of Climate and Applied Meteorology, 24, p. 1196 - 1207.

VITTE, A. C., 2006, A terceira crítica Kantiana e sua influência no moderno conceito de Geografia Física. GEOUSP, 19, p. 33 - 52.

VOOGT, J. A. and OKE, T. R., 1991, Validation of an urban canyon radiation model for nocturnal long-wave fluxes. Boundary - Layer Meteorology, 54, p. 347 - 361.

VOOGT, J. A. and OKE, T. R., 1997, Complete Urban Surface Temperatures. Journal of Applied Meteorology, 36, p. 1117 - 1132.

VOOGT, J. A. and OKE, T. R., 1998a, Effects of urban surface geometry on remotely sensed surface temperature. International Journal of Remote Sensing, 19, p. 895920.

VOOGT, J. A. and OKE, T. R., 1998b, Radiometric temperatures of urban canyon walls obtained from vehicle traverses. Theoretical and Applied Climatology, 60, p. 199217.

VOOGT, J. A. and OKE, T. R., 2003, Thermal remote sensing of urban climates. Remote Sensing of Environment, 86, p. 370 - 384. 
WEBB, E. K., PEARMAN, G. I. and LEUNING, R., 1980, Correction of flux measurements for density effects due to heat and water vapour transfer. Quarterly Journal of the Royal Meteorological Society, 106, p. 85 - 100.

WAllACE, J. M. and HOBBS, P. V., 2006, Atmospheric Science - an introductory survey. International Geophysics Series, vol. 92. San Diego, Academic Press, $2^{\text {nd }}$ ed. 